\title{
Life Cycle Assessment Comparing the Use of Jatropha Biodiesel in the Indian Road and Rail Sectors
}

Technical Report NREL/TP-6A2-47462

May 2010

Michael Whitaker

Symbiotic Engineering

Boulder, Colorado

Garvin Heath

National Renewable Energy Laboratory

Golden, Colorado 


\section{Life Cycle Assessment Comparing the Use of Jatropha Biodiesel in the Indian Road and Rail Sectors}

Michael Whitaker

Symbiotic Engineering

Boulder, Colorado

Garvin Heath

National Renewable Energy Laboratory

Golden, Colorado

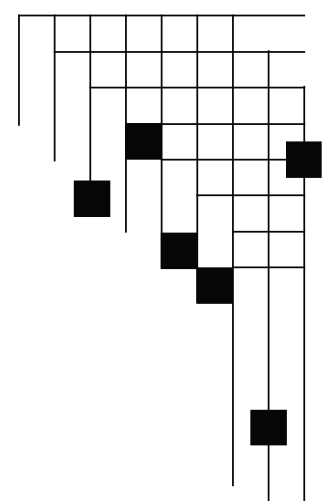

Prepared under Task No. BB07.9610 


\section{NOTICE}

This report was prepared as an account of work sponsored by an agency of the United States government. Neither the United States government nor any agency thereof, nor any of their employees, makes any warranty, express or implied, or assumes any legal liability or responsibility for the accuracy, completeness, or usefulness of any information, apparatus, product, or process disclosed, or represents that its use would not infringe privately owned rights. Reference herein to any specific commercial product, process, or service by trade name, trademark, manufacturer, or otherwise does not necessarily constitute or imply its endorsement, recommendation, or favoring by the United States government or any agency thereof. The views and opinions of authors expressed herein do not necessarily state or reflect those of the United States government or any agency thereof.

Available electronically at http://www.osti.gov/bridge

Available for a processing fee to U.S. Department of Energy and its contractors, in paper, from:

U.S. Department of Energy

Office of Scientific and Technical Information

P.O. Box 62

Oak Ridge, TN 37831-0062

phone: 865.576 .8401

fax: 865.576 .5728

email: mailto:reports@adonis.osti.gov

Available for sale to the public, in paper, from:

U.S. Department of Commerce

National Technical Information Service

5285 Port Royal Road

Springfield, VA 22161

phone: 800.553.6847

fax: 703.605.6900

email: orders@ntis.fedworld.gov

online ordering: http://www.ntis.gov/ordering.htm 


\section{Acknowledgements}

The authors would first like to thank our local partner for this work, the Indian Oil Corporation Ltd. (IOC), and specifically the contributions of Dr. Rakesh Sarin and Dr. Suresh Puri in providing helpful guidance that focused our modeling on the large-scale Jatropha biodiesel systems that the Indian government and the IOC envision. Margaret Mann and Anelia Milbrandt, both of NREL, lent their expertise in life cycle assessment modeling and Jatropha production, and Dr. Mark Pitterle of Symbiotic Engineering aided in the literature survey required to benchmark the results. Two reviewers also offered many useful comments that have improved the quality and clarity of communication: Jennifer Baka of Yale University and Yimin Zhang of NREL. Finally, we would like to thank the sponsors of this work, the Office of Biomass Programs within the Office of Energy Efficiency and Renewable Energy of the U.S. Department of Energy. 


\section{Abbreviations and Nomenclature}

B5

B10

B20

B100

biodiesel

$\mathrm{CH}$

$\mathrm{CH} 4$

$\mathrm{CO} 2$

$\mathrm{CO} 2 \mathrm{e}$

diesel

ETp

GB

GHG

GTK

GWP

IOC

IPCC

IR

Jatropha

$\mathrm{KCl}$

LCA

LCI

LCIA

MSRTH

$\mathrm{mtCO} 2 \mathrm{e}$

$\mathrm{N} 2 \mathrm{O}$

NER

NEV
$5 \%$ biodiesel blend with diesel

$10 \%$ biodiesel blend with diesel

$20 \%$ biodiesel blend with diesel

100\% biodiesel (neat biodiesel)

biodiesel produced from Jatropha oil using base-catalyzed

transesterification

Switzerland

methane

carbon dioxide

carbon dioxide equivalent in terms of global warming potential

considering other greenhouse gases

convention petroleum diesel

potential evapotranspiration

United Kingdom

greenhouse gas

gross tonne-kilometer

global warming potential

Indian Oil Corporation, Ltd.

Intergovernmental Panel on Climate Change

Indian Railways

Jatropha curcas L.

potassium chloride

life cycle assessment

life cycle inventory

life cycle impact assessment

Ministry of Shipping, Road Transport, and Highways

metric tonne carbon dioxide equivalent

nitrous oxide

net energy ratio

net energy value 
NG

NREL

OCE

pkm

Planning Commission

RER

$\mathrm{RME}$

$\mathrm{S}$

T\&D

tonne

$\mathrm{U}$

UCTE

UCPTE

U. S.

VIZAG

vkm
Nigeria

National Renewable Energy Laboratory

oceanic

passenger kilometer traveled

Planning Commission, Government of India

Europe

Middle East

system process

transmission and distribution of electricity

metric ton

unit process

Union for the Co-ordination of Transmission of Electricity

Union for the Co-ordination of Production and Transmission of

Electricity (predecessor to UCTE)

United States

Visakhapatnam Oil Refinery

vehicle kilometer traveled 


\section{Abstract}

This life cycle assessment of Jatropha biodiesel production and use evaluates the net greenhouse gas (GHG) emission (not considering land-use change), net energy value (NEV), and net petroleum consumption impacts of substituting Jatropha biodiesel for conventional petroleum diesel in India. Several blends of biodiesel with petroleum diesel are evaluated for the railfreight, rail-passenger, road-freight, and road-passenger transportation sectors that currently rely heavily on petroleum diesel. For Jatropha cultivation, processing, and use under base case conditions, combustion of B20 results in a net reduction in life cycle GHG emissions and petroleum consumption of $14 \%$ and $17 \%$, respectively, and a NEV increase of $58 \%$ compared with the use of $100 \%$ petroleum diesel. While the road-passenger transportation sector provides the greatest benefits in the evaluated metrics per 1000 gross tonne kilometers, the road-freight sector eventually provides the greatest absolute benefits owing to substantially higher projected utilization by year 2020. Nevertheless, introduction of biodiesel to the rail sector might present the fewest logistic and capital expenditure challenges in the near term. Sensitivity analyses confirmed that the evaluated sustainability benefits are maintained under multiple plausible cultivation, processing, and distribution scenarios. However, the sustainability of any individual Jatropha plantation will depend on site-specific conditions and most importantly on seed yield. 


\section{Executive Summary}

\section{Issues}

India's transportation sector relies heavily on petroleum-based fuels that account for over $95 \%$ of the transportation sector's energy use (Planning Commission 2003) with over 70\% of petroleumbased fuels imported (Sarin 2008a). Moreover, combustion of petroleum-based fuels in India's transportation sector accounts for approximately $6 \%$ of the country's annual greenhouse gas (GHG) emissions (Pew Center on Global Climate Change 2008). In 2003, the Planning Commission recommended increasing the use of biodiesel blended with petroleum diesel in transportation fuels with the goal of reducing GHG emissions and petroleum consumption. The Planning Commission of the Government of India (Planning Commission) selected Jatropha curcas L. (Jatropha) as the most suitable plant for the production of biodiesel in India because of its high oil-yielding seeds and ability to grow in a variety of agro-climatic conditions (Planning Commission 2003). Also in 2003, the Indian Oil Corporation, Ltd. (IOC) signed a memorandum of understanding with Indian Railways (IR) to explore the use of biodiesel in the Indian rail system (Ministry of Railways 2003). IR offered land to the IOC for the cultivation of Jatropha trees to produce Jatropha oil that could be extracted and transesterified into biodiesel for use in IR locomotives. Jatropha-based biodiesel is poised to provide an increasingly large share of the Indian transportation sector's energy needs, according to the Planning Commission's recommendations and the IOC-IR agreement, perhaps fulfilling a significant fraction of the $20 \%$ blending target for biodiesel by 2017, as set forth in a 2008 governmental standard and 2009 National Policy on Biofuels (Padma 2008; Ministry of New \& Renewable Energy, 2009).

\section{Objectives}

This study employs life cycle assessment to estimate certain environmental sustainability and energy security impacts of substituting petroleum diesel with Jatropha biodiesel blends in the Indian transportation sector. Four diesel-consuming vehicle classes are considered-road-freight transport, road-passenger transport via buses, rail-freight transport, and rail-passenger transport - to determine which class provides the greatest benefits compared to current petroleum diesel consumption. Passenger vehicles are not considered in this assessment because they are primarily fueled by gasoline. The primary sustainability and energy security metrics evaluated are net, life cycle GHG emissions, petroleum consumption, and net energy value (NEV). The study seeks to determine the relative reductions in GHG emissions and petroleum consumption and changes in NEV for multiple biodiesel blends compared to petroleum diesel, and to project potential absolute GHG and petroleum consumption reductions in each of the four analyzed transportation sectors for both current conditions (approximated with measured data from year 2006) and potential future conditions (approximated with projected data for year 2020). The base case scenario is modeled after projections from the Planning Commission (2003), which envisions a large-scale, centralized Jatropha cultivation and biodiesel production system utilizing marginal lands. The impact on results of alternative cultivation and biodiesel production scenarios are also evaluated. Finally, to help guide future Jatropha biodiesel research and development efforts in India, parametric sensitivity analysis is used to identify the most influential input parameters.

\section{Study Design}

This study expands upon a previous study that focused exclusively on the rail sector (Whitaker and Heath 2009), and it allows for the determination of which of the four evaluated transport 
modes provides the greatest opportunities for certain sustainability benefits from fuel switching. The life cycle system boundary of Jatropha biodiesel examined here includes Jatropha cultivation, Jatropha oil extraction, base-catalyzed Jatropha oil transesterification ${ }^{1}$ to biodiesel, and combustion of blends by volume of 5\% (B5), 10\% (B10), and 20\% (B20) biodiesel in Indian locomotives and diesel-fueled buses and trucks. B100 (100\% biodiesel or "neat biodiesel") results are also presented for reference. India-specific data were used to the extent they were available; close proxies were used where necessary. The petroleum-diesel reference system to which the results for Jatropha biodiesel are compared includes consideration of crude oil extraction and transportation, crude oil refining to diesel fuel, and diesel fuel combustion in Indian transport vehicles. The impacts resulting from changes in land use that could be induced by either the Jatropha systems or the petroleum systems are not considered in this study.

Blends of Jatropha biodiesel are compared to petroleum diesel based on three primary metrics: net changes in life cycle GHG emissions, net changes in petroleum consumption, and the NEV of the fuel production and use. Petroleum displacement is also reported to provide a more direct estimation of reductions in petroleum consumption under different biodiesel blend percentages compared to the conventional petroleum diesel reference case. ${ }^{2}$ For comparison with Whitaker and Heath (2009) and other references, net energy ratio is also presented even though the NEV is a more robust metric (see Section 5.2 for definition of NEV).

One thousand gross tonnes of goods or passengers hauled one kilometer (1000 gross tonne kilometer (GTK)) is the functional unit used to consistently compare those metrics across the four transport modes, hereafter referred to as the normalized results. A system lifetime of 20 years is assumed, with 2 billion GTK transported over that period by each mode. Annual GHG emissions and petroleum consumed are also estimated for use in determining the mode with the greatest potential for these sustainability benefits, hereafter referred to as the absolute results.

As multiple alternative biodiesel development pathways are plausible, the study developed extensive sensitivity analyses, including both scenario sensitivity analyses and parametric sensitivity analyses. Alternative scenarios test the impact of changes in land quality, applied cultivation practices, and transport distances for Jatropha seeds and processed biodiesel on analysis results. One-at-a-time parametric sensitivity analyses test the influence of individual input parameters to each of the evaluated metrics.

Seed yield per hectare is a critical parameter in determining the sustainability of Jatropha biodiesel production systems, but the literature lacks consensus on reasonable expected seed yields. Acquiring accurate estimates of seed yield data is further complicated by the absence of published data from large-scale, mature Jatropha plantations in India. The base case scenario for this study assumes a dry seed yield of 3.75 tonnes per hectare per year (tonnes/ha-yr) based on projections by the Planning Commission of India (2003). This yield value falls within the range

\footnotetext{
${ }^{1}$ Transesterification is used in this report to refer to all of the steps involved in the process of converting Jatropha oil to biodiesel. In transesterification, an alcohol is reacted with triglyceride oils, forming fatty acid alkyl esters (biodiesel) and glycerol. Heat and a strong base catalyst are commonly used to speed the reaction.

${ }^{2}$ Petroleum displacement is defined as the difference between life cycle petroleum consumed by the petroleum diesel reference case and the life cycle petroleum consumed by a specific biodiesel blend (including the petroleum diesel portion). Note that petroleum includes all crude oil-derived products such as gasoline, diesel, and oil lubricants, and petroleum displacement is measured in kilograms of crude oil reduced.
} 
of Jatropha seed yield values reported in the literature. For example, in their analysis of Jatropha cultivation in West Africa, Ndong and colleagues (2009) assume a base case Jatropha dry seed yield of 4.0 tonnes/ha-yr. Similarly, additional studies (Reinhardt et al. 2008 and Jongschaap et al. 2007) report observed and projected Jatropha seed yields of greater than 4.0 tonnes/ha-yr under good growing conditions. However, many of the references used in this study (Reinhardt et al. 2008, Jongschaap et al. 2007, Planning Commission of India 2003) suggest that seed yields can be reduced to a range of 1.0-2.5 tonnes/ha-yr under suboptimal growing conditions (e.g. inadequate water availability or lack of nutrients).

Due to the variation in seed yield estimates and to the large influence of seed yield on the sustainability metrics considered in this study, Section 7.1 contains scenario sensitivity analyses that examine the impacts of varying both seed yield and cultivation inputs while Section 7.2 contains a parametric sensitivity analysis of seed yield to model the impacts of changing only dry seed yield under base case conditions. Assuming the same cultivation inputs, maintenance, transport, and processing practices as the base case, the model predicts that no GHG emission reduction compared to petroleum diesel will be realized if seed yield falls below 1.25 tonnes/ ha-yr. While well correlated data sets for Jatropha seed yield do not exist, current observations of Jatropha cultivation in the literature suggest that seed yields below 1.25 tonnes/ha-yr are possible if land conditions are poor or if water availability is limited. Therefore, the GHG emission reductions reported by this study will be decreased or possibly non-existent if realized seed yield is less than the base case assumption of this study. 


\section{Base Case, Normalized Sustainability Metrics of Jatropha Biodiesel}

The results of the base case analysis, normalized per 1000 GTK, are summarized in Table ES-1, Table ES-2, and Table ES-3. The results suggest that substituting petroleum diesel with Jatropha biodiesel yields reductions in both GHG emissions and petroleum consumption that scale with the proportion of biodiesel used in the blend. Under base case conditions, Table ES- 1 shows that substituting petroleum diesel with B5 could reduce GHG emissions by $3.4 \%$, by $14 \%$ for B20 and, for reference, by $72 \%$ for B100, compared to the use of petroleum diesel.

As shown in Table ES-2, the NEV of B100 is positive for all modes (useful energy output being greater than the cumulative energy inputs), and the NEV of petroleum diesel is negative for all modes. Increasing the percentage of biodiesel improves the NEV of the blended fuels by making the combined NEVs for the diesel/biodiesel mixes less negative with increases in NEV compared to petroleum diesel of $14 \%, 29 \%$, and $58 \%$ for B5, B10, and B20 blends, respectively. For comparison to Whitaker and Heath (2009) and to other biofuel LCAs, the base case net energy ratio for Jatropha biodiesel (B100) is estimated in this study to be 2.3, meaning that more than 2 units of energy are produced for every one unit of energy consumed in the production process.

Table ES-1. Comparison of net life cycle greenhouse gas (GHG) emission intensity $\left(\mathrm{kg} \mathrm{CO}{ }_{2} \mathrm{e} / 1,000\right.$ GTK) for the base cases for each of the four transport modes evaluated in this study, and the percent change from the petroleum diesel baseline*

\begin{tabular}{lccccc}
\hline & Diesel & B5 & B10 & B20 & B100 \\
\cline { 2 - 6 } Rail Transport-Freight & 7.9 & 7.6 & 7.4 & 6.8 & 2.3 \\
Rail Transport-Passenger & 13 & 13 & 12 & 11 & 3.8 \\
Road Transport-Freight & 39 & 37 & 36 & 33 & 11 \\
Road Transport-Passenger & 51 & 49 & 47 & 44 & 15 \\
\hline Percent Change from Diesel $^{* *}$ & - & $-3.4 \%$ & $-6.8 \%$ & $-14 \%$ & $-72 \%$ \\
\hline
\end{tabular}

* The reported results assume a 20-year system lifetime with 2 billion GTK transported over that time. The study employs IPCC (2007) GWP values. Results are rounded to two significant figures as an indication of their uncertainty. ${ }^{* *}$ Percent change from the diesel reference system is constant for all transport modes as it is due to variations in the wells-to-pump portion of the life cycle, assuming that the fuel economy decrement (biodiesel compared to diesel) does not vary by transport mode (Kathpal 2008, Basha et al. 2009). The percent changes reported here may not equal those achieved by calculation using the results reported above owing to independent rounding.

Table ES-2. Comparison of net energy value (MJ/1,000 GTK) for the base case for each of the four transport modes evaluated in this study, and the percent change from the petroleum diesel baseline*

\begin{tabular}{lcrrrr}
\hline & Diesel & \multicolumn{1}{l}{ B5 } & B10 & B20 & B100 \\
\cline { 2 - 6 } Rail Transport-Freight & -26 & -22 & -18 & -11 & 52 \\
Rail Transport-Passenger & -42 & -36 & -30 & -18 & 87 \\
Road Transport-Freight & -120 & -110 & -88 & -52 & 250 \\
Road Transport-Passenger & -160 & -140 & -120 & -68 & 340 \\
\hline Percent Change from & - & $14 \%$ & $29 \%$ & $58 \%$ & $300 \%$ \\
Diesel $^{*}$ & - & & & & \\
\hline
\end{tabular}

* The reported results assume a 20-year system lifetime with 2 billion GTK transported over that time. The study employs IPCC (2007) GWP values. Results are rounded to two significant figures as an indication of their uncertainty. ** Percent change from the diesel reference system is constant for all transport modes as it is due to variations in the wells-to-pump portion of the life cycle, assuming that the fuel economy decrement (biodiesel compared to diesel) does not vary by transport mode (Kathpal 2008, Basha et al. 2009). The percent changes reported here may not equal those achieved by calculation using the results reported above owing to independent rounding. 
In terms of petroleum consumed by transport vehicles, Table ES-3 shows that, compared to the current situation of petroleum diesel fuel usage, B5 could displace $4.2 \%$ of petroleum use, B20 $17 \%$ and B100 88\%, under the base case conditions evaluated in this study.

Table ES-3. Comparison of net petroleum consumption intensity (kg crude oil/1,000 GTK) and net petroleum displacement intensity (kg crude oil/1,000 GTK) for the base case for each of the four transport modes evaluated in this study, and the percent change from the petroleum diesel baseline*

\begin{tabular}{|c|c|c|c|c|c|}
\hline & Diesel & B5 & B10 & B20 & B100 \\
\hline \multicolumn{6}{|l|}{ Rail Transport-Freight } \\
\hline $\begin{array}{l}\text { Net Petroleum } \\
\text { Consumption Intensity }\end{array}$ & 2.5 & 2.4 & 2.3 & 2.1 & 0.30 \\
\hline $\begin{array}{l}\text { Net Petroleum } \\
\text { Displacement Intensity }\end{array}$ & - & 0.10 & 0.21 & 0.42 & 2.2 \\
\hline \multicolumn{6}{|l|}{ Rail Transport-Passenger } \\
\hline $\begin{array}{l}\text { Net Petroleum } \\
\text { Consumption Intensity }\end{array}$ & 4.1 & 4.0 & 3.8 & 3.4 & 0.50 \\
\hline $\begin{array}{l}\text { Net Petroleum } \\
\text { Displacement Intensity }\end{array}$ & - & 0.17 & 0.35 & 0.70 & 3.6 \\
\hline \multicolumn{6}{|l|}{ Road Transport-Freight } \\
\hline $\begin{array}{l}\text { Net Petroleum } \\
\text { Consumption Intensity }\end{array}$ & 12 & 12 & 11 & 10 & 1.5 \\
\hline $\begin{array}{l}\text { Net Petroleum } \\
\text { Displacement Intensity }\end{array}$ & - & 0.51 & 1.0 & 2.0 & 11 \\
\hline \multicolumn{6}{|l|}{ Road Transport-Passenger } \\
\hline $\begin{array}{l}\text { Net Petroleum } \\
\text { Consumption Intensity }\end{array}$ & 16 & 15 & 15 & 13 & 1.9 \\
\hline $\begin{array}{l}\text { Net Petroleum } \\
\text { Displacement Intensity }\end{array}$ & - & 0.67 & 1.3 & 2.7 & 14 \\
\hline Percent Change from Diesel ${ }^{\star \star}$ & - & $-4.2 \%$ & $-8.4 \%$ & $-17 \%$ & $-88 \%$ \\
\hline
\end{tabular}

* The reported results assume a 20-year system lifetime with 2 billion GTK transported over that time. The study employs IPCC (2007) GWP values. Results are rounded to two significant figures as an indication of their uncertainty. ${ }^{* *}$ Percent change from the diesel reference system is constant for all transport modes as it is due to variations in the wells-to-pump portion of the life cycle, assuming that the fuel economy decrement (biodiesel compared to diesel) does not vary by transport mode (Kathpal 2008, Basha et al. 2009). The percent changes reported here may not equal those achieved by calculation using the results reported above owing to independent rounding.

\section{Projected, Absolute Sustainability Benefits of Jatropha Biodiesel under the Base Case Scenario}

Additional insight into the potential benefits regarding certain sustainability and energy security attributes from transitioning to Jatropha B20 throughout the transportation sector, as envisioned by the Planning Commission (2003), is gained by projecting potential annual savings across all four analyzed transportation sectors. Tables ES-4 and ES-5 examine potential annual reductions in GHG emissions and crude oil consumption if Jatropha B20 produced under base case conditions is fully substituted into each of the four diesel-fueled transportation markets. Diesel fuel demand in the years 2006 and 2020 are analyzed to determine the transport modes with the greatest potential absolute impact both under current conditions and in the future. These projections are not meant to convey the likelihood of achieving the calculated benefits or of realizing full market penetration for B20. 
Table ES-4. Projected net life cycle GHG-emission reductions for complete substitution of petroleum diesel with Jatropha B20 produced under base case conditions in the four transport modes analyzed in this study*

\begin{tabular}{|c|c|c|c|c|}
\hline \multirow[b]{2}{*}{ Transport Mode } & \multicolumn{2}{|c|}{ Current Conditions } & \multicolumn{2}{|c|}{2020} \\
\hline & $\begin{array}{l}\text { Estimated } \\
\text { Gross Tonne } \\
\text { Kilometers } \\
\text { (in billions) }\end{array}$ & $\begin{array}{l}\text { Total GHG } \\
\text { Emission } \\
\text { Reductions for } \\
\mathrm{B} 20\left(\mathrm{mtCO}_{2} \mathrm{e}\right)\end{array}$ & $\begin{array}{l}\text { Estimated } \\
\text { Gross Tonne } \\
\text { Kilometers } \\
\text { (in billions) }\end{array}$ & $\begin{array}{l}\text { Total GHG } \\
\text { Emission } \\
\text { Reductions for } \\
\mathrm{B} 20\left(\mathrm{mtCO}_{2} \mathrm{e}\right)\end{array}$ \\
\hline Rail Transport-Freight & 320 & 350,000 & 1,100 & $1,200,000$ \\
\hline Rail Transport-Passenger & 230 & 420,000 & 420 & 760,000 \\
\hline Road Transport-Freight & 660 & $3,500,000$ & 4,400 & $23,000,000$ \\
\hline Road Transport-Passenger & 1,300 & $9,100,000$ & 2,100 & $15,000,000$ \\
\hline Total-All Analyzed Modes & 2,500 & $13,000,000$ & 8,000 & $40,000,000$ \\
\hline
\end{tabular}

* Figures rounded to two significant figures as an indication of their uncertainty. Columns may not sum due to independent rounding of each value. Sources for GTK calculations and projections include Ministry of Shipping, Road Transport, and Highways (2009), Whitaker (2007), Singh (2005), Singh (2008), Ministry of Railways (2008), and Planning Commission (2007). See Section 8.3 of this study for details.

As shown in Table ES-4, under current conditions, the greatest absolute reductions in GHG emissions can be achieved by substituting B20 for petroleum diesel in the road transport sector via passenger buses as buses in India utilize the greatest GTK per year of the four analyzed sectors. Potential savings for the road-passenger sector are approximately 9.1 million $\mathrm{mt}$ $\mathrm{CO}_{2} \mathrm{e} / \mathrm{yr}$, nearly $70 \%$ of the total potential absolute savings under current conditions. However, by 2020 , with a greater share of Indian passenger transport expected to take place in personal vehicles and freight-road transport expected to grow rapidly as the economy expands, freightroad transport becomes the most critical sector to target for B20 substitution to maximize absolute gains. Projected reductions in freight-road transport comprise over $57 \%$ of potential absolute $2020 \mathrm{GHG}$-emission reductions with the combination of road transport freight and passenger accounting for over $95 \%$ of potential reductions.

As shown in Table ES-5, similar to GHG-emission reductions, passenger and freight-road transport comprise the greatest portions of potential absolute reductions in petroleum consumption with road-passenger transport having a greater share under current conditions and road-freight transport having a greater share by 2020. Combined, the two road sectors account for approximately $93 \%$ of potential absolute petroleum consumption reductions under current conditions and $98 \%$ of potential reductions by 2020 . 
Table ES-5. Projected petroleum displacement for complete substitution of Jatropha B20 produced under base case conditions for conventional diesel in the four transport modes analyzed in this study*

\begin{tabular}{|c|c|c|c|c|}
\hline \multirow[b]{2}{*}{ Transport Mode } & \multicolumn{2}{|c|}{ Current Conditions } & \multicolumn{2}{|c|}{2020} \\
\hline & $\begin{array}{l}\text { Estimated } \\
\text { Annual Gross } \\
\text { Tonne } \\
\text { Kilometers } \\
\text { (in billions) }\end{array}$ & $\begin{array}{l}\text { Total } \\
\text { Petroleum } \\
\text { Displacement } \\
\text { for B20 (tonnes } \\
\text { crude oil) }\end{array}$ & $\begin{array}{l}\text { Estimated } \\
\text { Annual Gross } \\
\text { Tonne } \\
\text { Kilometers } \\
\text { (in billions) }\end{array}$ & $\begin{array}{l}\text { Total } \\
\text { Petroleum } \\
\text { Displacement } \\
\text { for B20 (tonnes } \\
\text { crude oil) }\end{array}$ \\
\hline Rail Transport-Freight & 320 & 130,000 & 1,100 & 460,000 \\
\hline Rail Transport-Passenger & 230 & 160,000 & 420 & 290,000 \\
\hline Road Transport-Freight & 660 & $1,400,000$ & 4,400 & $9,000,000$ \\
\hline Road Transport-Passenger & 1,300 & $3,500,000$ & 2,100 & $5,700,000$ \\
\hline Total-All Analyzed Modes & 2,500 & $5,200,000$ & 8,000 & $15,000,000$ \\
\hline
\end{tabular}

${ }^{*}$ Figures rounded to two significant figures as an indication of their uncertainty. Columns may not sum due to independent rounding of each value. Sources for GTK calculations and projections include Ministry of Shipping, Road Transport, and Highways (2009), Whitaker (2007), Singh (2005), Singh (2008), Ministry of Railways (2008), and Planning Commission (2007). See body of report for details.

In total, the biodiesel requirements for substituting Jatropha B20 for all-petroleum diesel in the four transportation sectors analyzed in this study would require cultivation of nearly 5 million hectares of land under current conditions and approximately 14 million hectares by 2020 assuming a biodiesel yield of 1,300-1,400 liters per hectare (in line with the base case assumption in this study). The Planning Commission (2003) identified 13.4 million hectares of land for potential conversion to Jatropha cultivation with the land varying in quality from waste, abandoned, or fallow lands to farmlands requiring protective hedges and under-stocked forestland. That the amount of land identified by the Planning Commission nearly equals the land required for full B20 substitution does not imply a prediction that transitioning such a large, diverse and geographically disparate amount of land to Jatropha cultivation would be economically, politically and logistically achievable. In addition, transitioning of vegetated land to Jatropha cultivation may lead to an increase or decrease in GHG emissions from direct landuse change depending on the local conditions at the plantation site. If determining robust estimates of the potential GHG emissions associated with the set of specific land tracts identified for Jatropha cultivation is important, then additional research on the topic of GHG emissions associated with land use change should be prioritized. Also, these projections do not account for population growth, increasing affluence, and other socio-economic and demographic changes that could impact the availability of land for Jatropha cultivation.

Targeting the sector with the greatest absolute benefits may not be the most strategic approach to maximizing the benefits of Jatropha biodiesel, as the volume of fuel required may exceed supply, financial capital for infrastructure changes are likely limited, and the logistics of fueling vehicles in each sector differ. The near-term total substitution of B20 for all-petroleum diesel may be most feasible in the rail sector as approximately 370 million liters of biodiesel would be required compared to 6.1 billion liters for the road sector. In addition, the rail sector uses relatively few, centralized fueling depots. However, the greatest absolute reductions in GHG emissions and petroleum consumption for the analyzed transportation sectors are achievable in the passenger bus-road transport sector. While requiring a greater investment in fueling infrastructure than the rail sector, the presence of centralized bus depots still provides the opportunity to fuel numerous 
vehicles with B20 from one location while beginning to address the transportation sector with the greatest near-term potential absolute reductions. As more biodiesel becomes available and fueling infrastructure investments increase, the focus can transition to the availability of roadside B20 fueling stations that could provide fuel to the freight-road transportation sector. It is anticipated that by 2020 the greatest absolute reductions in both GHG emissions and petroleum consumption will be achievable from the substitution of B20 for petroleum diesel in the freightroad sector.

\section{Sensitivity Analyses}

Scenario sensitivity analyses evaluate alternative plausible scenarios for the cultivation, processing, transport, and use of Jatropha biodiesel. The base case scenario conditions are based on projections by the Planning Commission (2003) that may be considered optimized as they anticipate yields of $3,750 \mathrm{~kg}$ dry seed/ha and oil contents of $35 \%$ by weight on lands that are marginal but require moderate maintenance. However, with a program of this scale, it is important to analyze whether the substantial benefits for sustainability and energy security projected in the base case scenario of this study (Tables ES-1, ES-2, and ES-3) can be maintained even if the anticipated cultivation and processing conditions are not met. See Section 7.1 for a detailed description of the analyzed sensitivity scenarios and their full results. The summary results discussed in this section compare GHG emissions and petroleum consumption for B100 to conventional diesel for each scenario.

Three alternative cultivation scenarios were explored:

1. "Marginal Land, Low Irrigation" models the impact of reduced yields resulting from reduced cultivation inputs on low quality, poorly maintained land.

2. "Marginal Land, High Maintenance" models the impact of cultivating Jatropha on low quality land but increasing cultivation inputs to maintain base case yields.

3. "Good Land, High Maintenance" assumes higher than base case yields can be achieved by increasing the intensity of cultivation inputs.

The first two scenarios reduce the GHG-emission and petroleum-displacement benefits primarily because of the reduced yields, higher cultivation inputs, or both. Nevertheless, the Marginal Land, Low Irrigation scenario still realizes GHG-emission reductions of $31 \%$ and petroleum consumption reductions of $66 \%$ compared with conventional diesel. The Marginal Land, High Maintenance scenario realizes GHG-emission savings of $59 \%$ and petroleum consumption savings of $80 \%$ compared with conventional diesel. Taken together, results from these two scenarios suggest that net life cycle GHG emissions and petroleum consumption levels will benefit from cultivation practices that focus on increasing yields and oil content as opposed to minimizing cultivation inputs. The Good Land, High Maintenance scenario reinforces the importance of achieving high yields by indicating that GHG-emission and petroleum consumption reductions for B100 will reach $82 \%$ and $93 \%$, respectively, compared with the conventional diesel baseline (values greater than the base case reductions of $72 \%$ and $88 \%$ ) if increased cultivation inputs are used to achieve high seed yields and oil contents on fertile land.

In addition to analyzing the alternative cultivation scenarios, this study also analyzed a scenario for biodiesel production with larger seed catchment areas and greater distribution distances than the base case. Another alternative scenario analyzed the impacts of assuming that Jatropha 
biomass is burned to generate process heat as opposed to the base case assumption of electricity production. Both of these alternative scenarios maintain GHG-emission reductions of at least $70 \%$ and petroleum consumption reductions of greater than $85 \%$.

The combined results of the scenario sensitivity analyses suggest that although the base case may be somewhat optimized, other plausible scenarios for Jatropha biodiesel production and use also yield significant savings in both GHG emissions and petroleum consumption. No analyzed scenarios yielded GHG-emission or petroleum consumption increases compared to the allpetroleum baseline, though that outcome might occur under the worst land-use change circumstances (e.g., if heavily vegetated lands with significant soil carbon stores were transformed for monoculture Jatropha plantations).

Parametric sensitivity analysis provides insight into the relative influence of individual input parameters on study results. The parametric analysis confirms that dry seed yield and seed oil content (together with biodiesel fuel consumption efficiency in transport vehicles) have the greatest influence on all three evaluated metrics.

\section{Limitations}

A limitation of this study is that it does not consider the potential impacts of land-use change. Two categories of land use change are discussed here: direct and indirect. Direct land use change occurs on the land used to cultivate Jatropha. For instance, land is converted from fallow, marginal or active use to a Jatropha plantation. Indirect land use change occurs on other land, whether domestic or foreign, as a result of the displacement of products produced from the land that has been converted to a Jatropha plantation. For instance, if an edible oil seed crop is grown on land converted to a Jatropha plantation, then the reduced supply of oil seed could induce a different market actor to convert other lands to make up for the lost supply.

Indirect (market-mediated) land-use change is not likely to be strongly linked to Jatropha production under current plans, which envision previously abandoned agricultural or otherwise degraded lands as Jatropha production zones (India Planning Commission 2003; Padma 2008; Ministry of New \& Renewable Energy, 2009). The availability of these lands appears to be plentiful and nearly equal to that required to produce enough Jatropha-based biodiesel to displace $20 \%$ of all petroleum diesel in the four transportation sectors analyzed in this study. However, in the absence of strictly enforced regulations preventing the use of currently cultivated lands for Jatropha plantations, the better economics of higher yields could induce some conversion of prime agricultural land to Jatropha plantations. If this were to occur, then indirect land use change would become an issue of greater potential significance for altering the GHG benefits of Jatropha biodiesel estimated in this study. However, as shown in the sensitivity analyses, the decrease in GHG emissions under the "good land, high maintenance" scenario should partially offset any impact from indirect land use change.

Conversion of the Planning Commission-identified lands to Jatropha production could result in greater, equal, or lesser soil carbon sequestration depending on the previous level of vegetation of the sites (Reinhardt et al. 2008). A bounding estimate based on data from Reinhardt et al. (2008) suggests that the maximum direct land-use change GHG emissions under the base case conditions of this study would equate to approximately the following percentages of total 20year net life cycle GHG emissions: $0.25 \%$ for passenger-road transport, $0.33 \%$ for freight-road 
transport, $1.0 \%$ for passenger-rail transport, and $1.6 \%$ for freight-rail transport. Therefore, the conclusions of the current study would not likely change significantly if the impacts of direct land-use change were included.

Additionally, this study does not perform an analysis of the feasibility of full market penetration of Jatropha biodiesel as B20, the economic viability of cultivating Jatropha only on marginal lands, or the potential market for the glycerine co-product as biodiesel production increases. The results of this study assume that glycerine is fully utilized as a co-product and that it offsets the production of synthetic glycerine. If glycerine co-product benefits are omitted, the analyzed sustainability and energy security benefits of Jatropha biodiesel production and use are diminished, but the conclusions of the study do not change. For example, omitting glycerine coproduct benefits from the base case analysis scenario decreases the GHG emission benefits of B100 compared with the petroleum diesel reference case from a $72 \%$ reduction to a $60 \%$ reduction. Thus, the conclusion that Jatropha biodiesel production and use has a net life cycle emission benefit compared with petroleum diesel reference case does not change.

Given the embryonic state of Jatropha research, there is considerable uncertainty in modeling Jatropha biodiesel production systems. Therefore, it is advisable to interpret the findings of this study as indicative of the direction and scale of impacts relative to the diesel reference system rather than accurate point estimates of the magnitude of impacts. Furthermore, given the focus of this study on large-scale Indian plantations and biodiesel production processes as well as on the use of biodiesel in the Indian transportation sector, the results presented here are not necessarily broadly applicable to other locations, other production processes, or other uses. While sensitivity analysis has been used to explore the variability in evaluated metrics based on alternative cultivation and production scenarios, future research should more comprehensively evaluate them to allow deeper insight into their impacts. Nevertheless, agreement between the results of this study and some others in the literature was found, suggesting increased confidence in certain impact estimates related to life cycle GHG emissions, net energy value, and petroleum consumption. Other sustainability metrics, such as impacts to soil, air, and water quality and impacts to economic and gender equity, were not evaluated in this study, but could be important in evaluating the overall sustainability of the production and use of Jatropha biodiesel in India.

\section{Conclusions}

With India's transportation sector heavily reliant on imported petroleum-based fuels, the Planning Commission and the Indian government recommended the increased use of blended biodiesel in transportation fleets, and identified Jatropha as a potentially important feedstock. IOC and IR are collaborating to increase the use of biodiesel blends in Indian transport vehicles with blends of up to B20, and the Ministry of New \& Renewable Energy (2009) set a goal of using B20 in the transportation sector by 2017. This study evaluated the life cycle GHG emissions, net energy value, and petroleum displacement impacts of integrating larger percentages of Jatropha-based biodiesel in transport vehicle operations in India and identified the parameters that have the greatest impact on selected sustainability metrics of the system. This study was designed to evaluate selected environmental sustainability measures of Jatropha cultivation, biodiesel production, and biodiesel blend utilization under conditions in India. 
For the base case considered, this study found that, per gross-tonne kilometer traveled, a blend of B20 would reduce GHG emissions by $14 \%$, reduce petroleum consumption by $17 \%$, and increase the net energy value by $58 \%$ compared with the conventional diesel baseline. Using sensitivity analyses, this study also identified dry seed yield, seed oil content, and biodiesel fuel consumption efficiency as the individual parameters with the greatest influence on all three of the sustainability metrics evaluated. Additionally, this study confirmed that reductions in the GHG emissions and petroleum consumption are maintained under a range of plausible biodiesel cultivation, processing, and distribution scenarios, though GHG emission reductions compared to petroleum diesel are reduced to zero if seed yield fall below 1,250 kg / ha-yr. Furthermore, while the base case did not consider the potential impacts of direct land-use change, a bounding estimate using results from Reinhardt et al. (2008) found that the magnitude and direction of benefits would likely not change considerably even if those potential impacts were considered.

As agro-climatic conditions and optimal biodiesel feedstocks vary widely throughout the world, no one study can definitively determine the sustainability of biofuels in all scenarios. However, this study's results — and the results of other reviewed studies — suggest that under multiple plausible growing conditions and production scenarios, Jatropha-based biodiesel shows promise for helping India achieve its GHG-emission reduction and petroleum displacement goals with the greatest potential reductions being achievable in the road bus, passenger transportation sector in the near term and in the road-freight transportation sector in 2020. However, additional economic and market penetration analyses are required to evaluate the potential for direct and indirect land-use change and co-product market viability associated with Jatropha cultivation expanding to meet required biodiesel production levels. In particular, expected seed and oil yields, required cultivation inputs, and existing site conditions, must be closely examined in assessing the sustainability of any proposed Jatropha biodiesel production project. 


\section{Table of Contents}

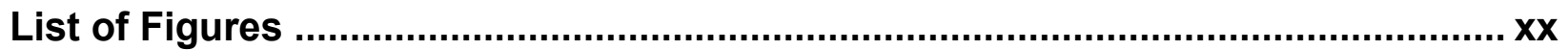

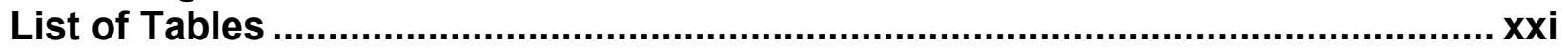

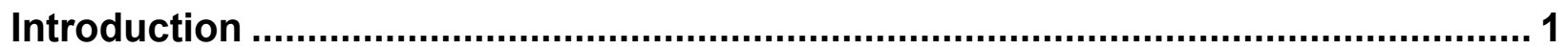

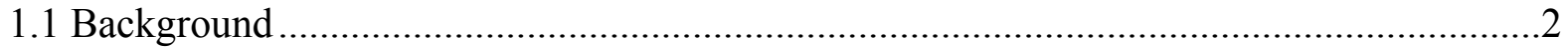

1.2 Overview of India's Petroleum Consumption and Greenhouse Gas Emissions ..................2

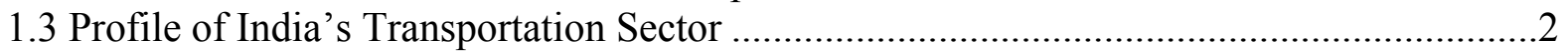

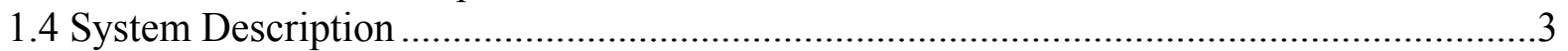

1.4.1 Life Cycle of Jatropha Biodiesel — General Description ............................................

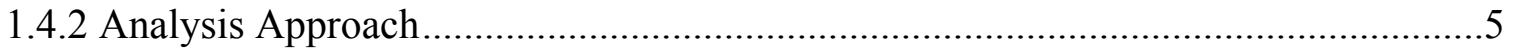

1.4.3 Jatropha Biodiesel Base Case Scenario Description...................................................

1.4.4 Reference System —Petroleum Diesel Production and Distribution ...........................8

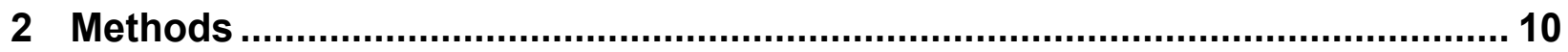

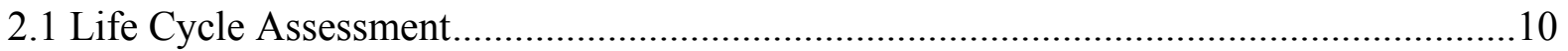

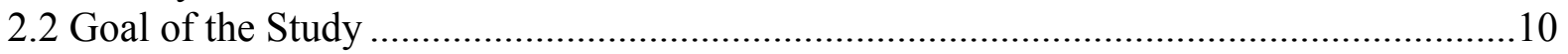

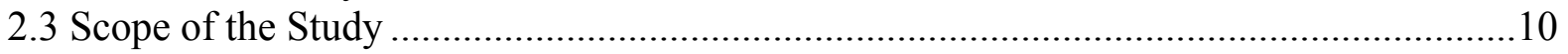

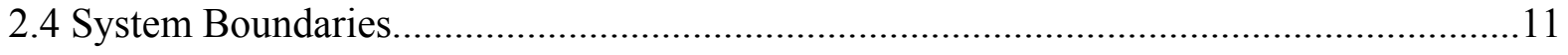

2.5 Allocation Procedures ..........................................................................................12

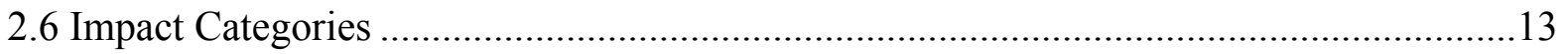

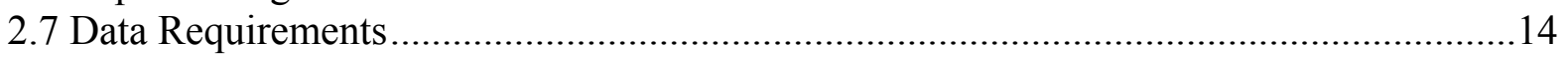

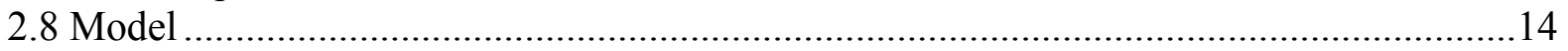

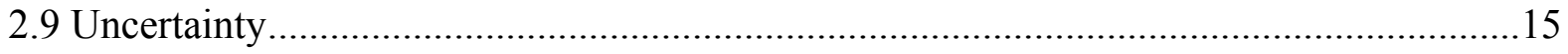

2.10 Sensitivity Analysis Approach...................................................................................16

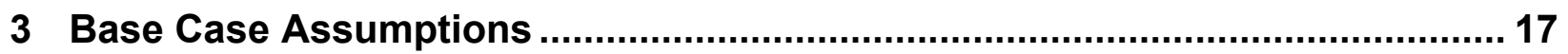

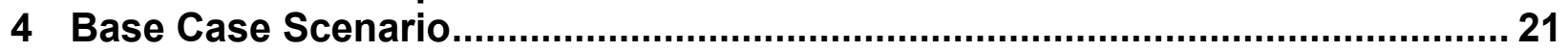

4.1 Petroleum Diesel Production and Distribution (Reference System).................................21

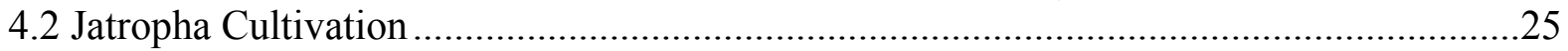

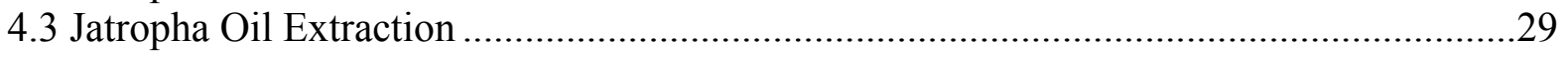

4.4 Biodiesel Production via Jatropha Oil Transesterification ....................................................

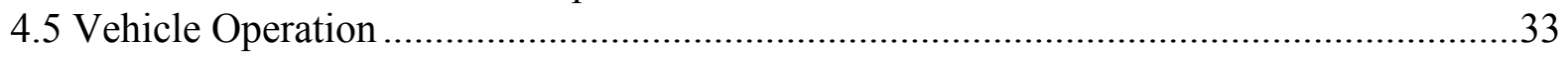

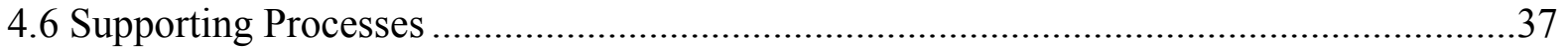

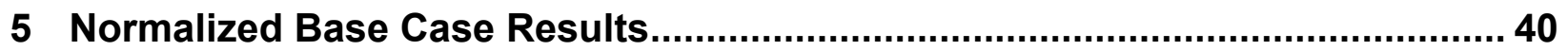

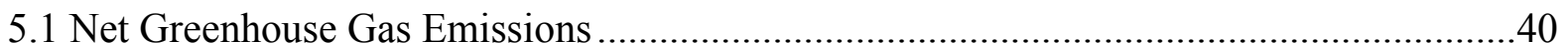

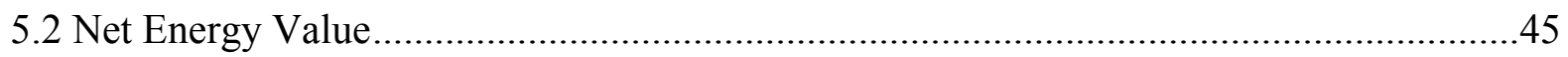

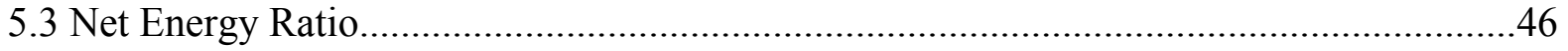

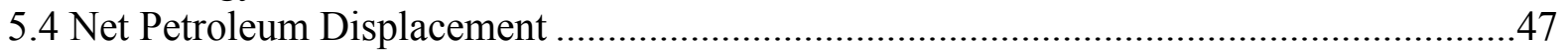

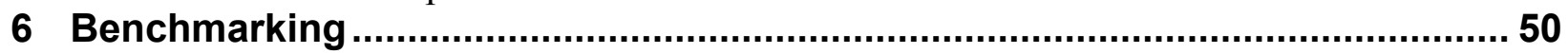

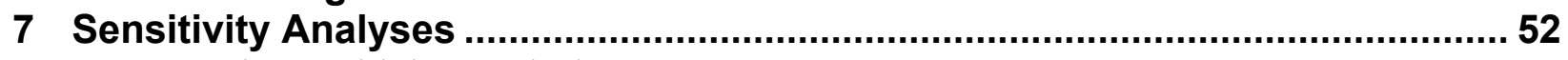

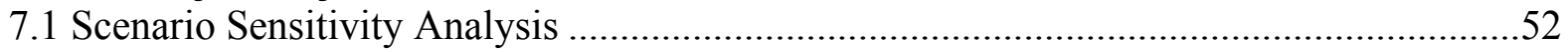

7.1.1 Sensitivity Scenario A: Marginal Land, Low Irrigation ..........................................52

7.1.2 Sensitivity Scenario B: Marginal Land, High Cultivation Maintenance ……….......55

7.1.3 Sensitivity Scenario C: Good Land, High Cultivation Maintenance.........................58 
7.1.4 Sensitivity Scenario D: Increased Seed Catchment and Biodiesel Distribution Distances

7.1.5 Sensitivity Scenario E: Biomass Offset-Heat........................................................64

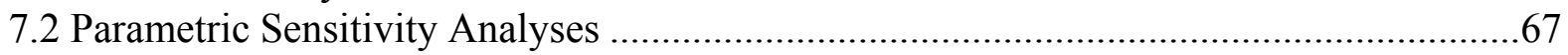

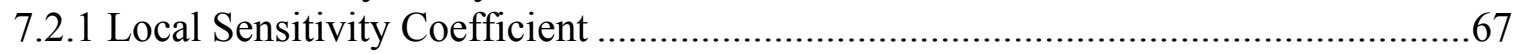

7.2.2 Individual Parameters Alternate Values ................................................................72

7.3 Interpretation and Comparison of Sensitivity Analyses ..................................................76

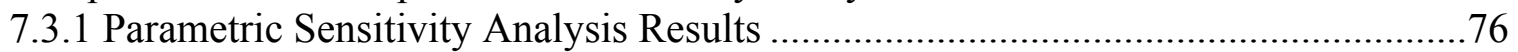

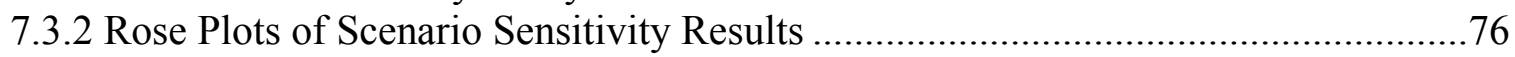

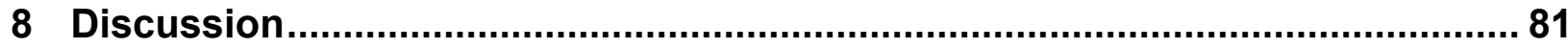

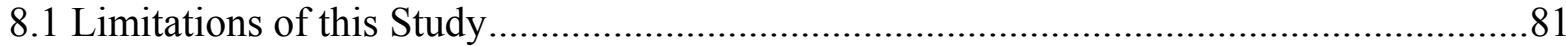

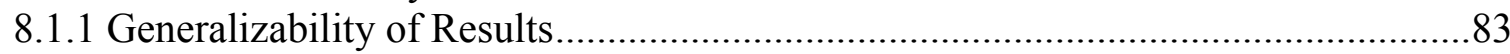

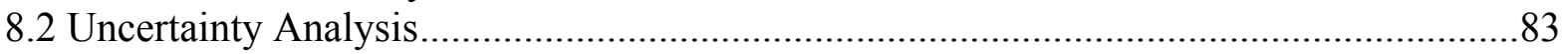

8.3 Projections of Absolute Petroleum Displaced and Net GHG Emission Reductions by Utilization of Jatropha Biodiesel in the Indian Road and Rail Sectors..............................84

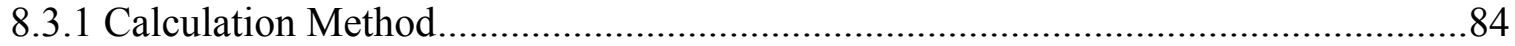

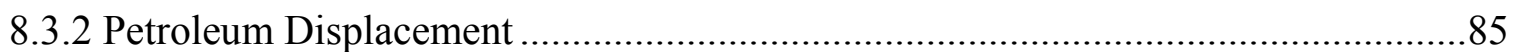

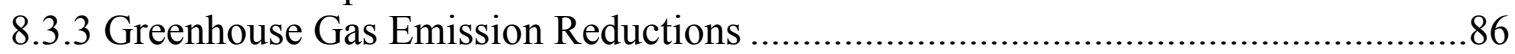

8.3.4 Transport Sector Comparison for Current Conditions and 2020 …..........................87

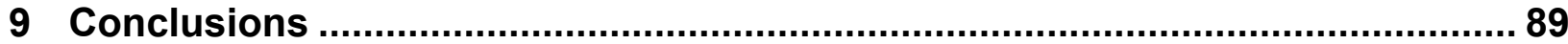

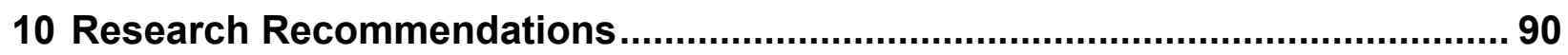

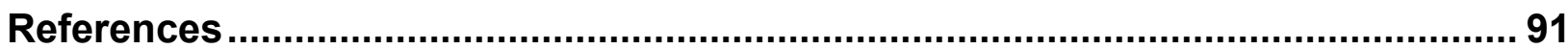

Appendix: SimaPro Model and Base Case Model Parameter Values ..................... 97 


\section{List of Figures}

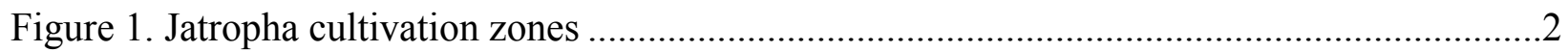

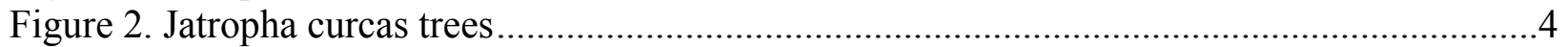

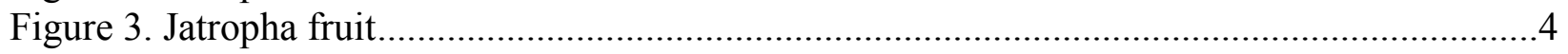

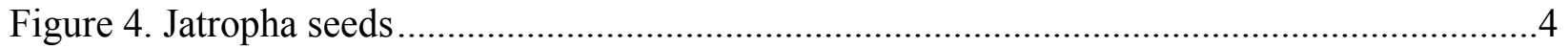

Figure 5. Chhattisgarh state, India, with the location of the city of Raipur indicated. .....................6

Figure 6. Schematic for continuous solvent oil extraction .........................................................

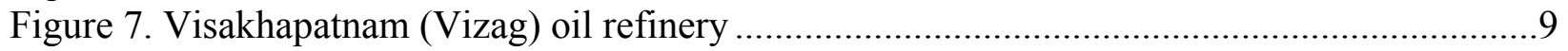

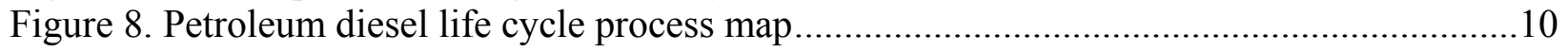

Figure 9. Blended biodiesel life cycle process map....................................................................11

Figure 10. Modeling schematic for petroleum diesel production and distribution processes .......22

Figure 11. Modeling schematic for Jatropha cultivation processes ...............................................25

Figure 12. Modeling schematic for Jatropha oil extraction processes..........................................29

Figure 13. Modeling schematic for biodiesel production via Jatropha oil transesterification

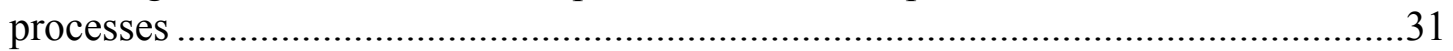

Figure 14. Modeling schematic for transport vehicle operation ...................................................34

Figure 15. Modeling schematic for Indian electricity ................................................................3

Figure 16. Result of sensitivity analysis on B100 net life cycle GHG emission intensity, as multiple of base case value ................................................................................77

Figure 17. Result of sensitivity analysis on B100 net energy value, as multiple of base case

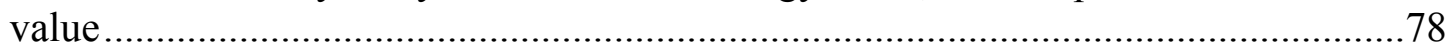

Figure 18. Result of sensitivity analysis on B100 net life cycle petroleum displacement

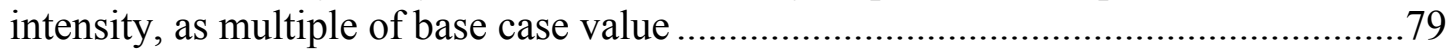

Figure 19. Result of sensitivity analysis on B100 net life cycle petroleum consumption intensity, as multiple of base case value 


\section{List of Tables}

Table ES-1. Comparison of net life cycle greenhouse gas (GHG) emission intensity (kg $\mathrm{CO}_{2} \mathrm{e} / 1,000 \mathrm{GTK}$ ) for the base cases for each of four transport modes evaluated in this study, and the percent change from the petroleum diesel baseline........................

Table ES-2. Comparison of net energy value (MJ/1,000 GTK) for the base case for each of four transport modes evaluated in this study, and the percent change from the petroleum diesel baseline.

Table ES-3. Comparison of net petroleum consumption intensity ( $\mathrm{kg}$ crude oil/ 1,000 GTK) and net petroleum displacement intensity (kg crude oil/ 1,000 GTK) for the base case for each of four transport modes evaluated in this study, and the percent change from the petroleum diesel baseline

Table ES-4. Projected net life cycle GHG-emission reductions for complete substitution of petroleum diesel with B20 produced under base case conditions in the four transport modes analyzed in this study

Table ES-5. Projected petroleum displacement for complete substitution of B20 produced under base case conditions for conventional diesel in the four transport modes analyzed in this study................................................................................................ xiii

Table 1. Global warming potentials (relative to $\mathrm{CO}_{2}$ ) of a subset of the greenhouse gases

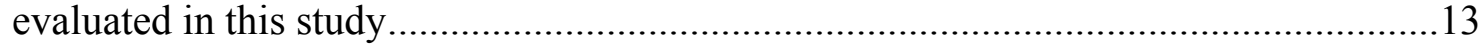

Table 2. SimaPro module descriptions for petroleum diesel production and distribution............23

Table 3. Base case data inputs for petroleum diesel production and distribution........................24

Table 4. SimaPro module descriptions for Jatropha cultivation ..........................................26

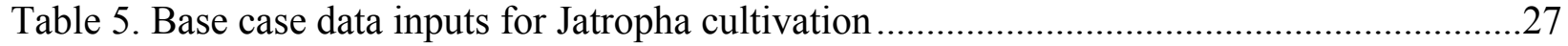

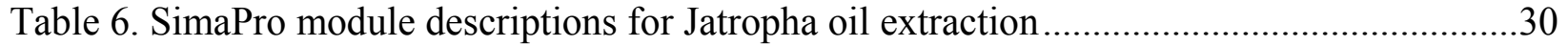

Table 7. Base case data inputs for Jatropha oil extraction ..................................................... 30

Table 8. SimaPro module descriptions for biodiesel production via Jatropha oil

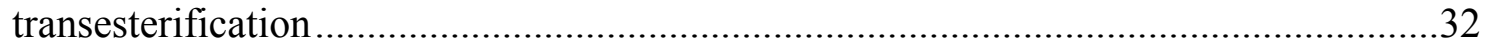

Table 9. Base case data inputs for biodiesel transesterification via Jatropha oil

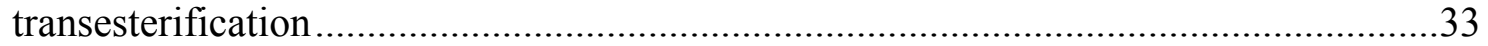

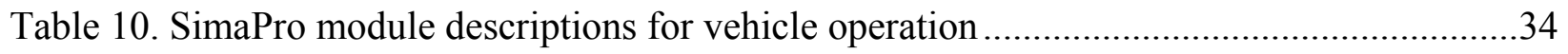

Table 11. Base case data inputs for transport vehicle operation .............................................35

Table 12. SimaPro module descriptions for Indian electricity ...............................................38

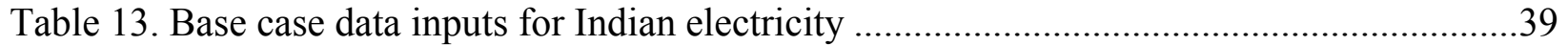

Table 14. SimaPro module descriptions for transportation of goods...........................................39

Table 15. Comparison of net life cycle GHG emission intensity $\left(\mathrm{kg} \mathrm{CO}_{2}\right.$ e per $\left.1,000 \mathrm{GTK}\right)$ for the base cases for each of four transport modes evaluated in this study ................41

Table 16. Well-to-pump GHG emissions ( $\mathrm{g} \mathrm{CO}_{2} \mathrm{e} / \mathrm{MJ}$ fuel) for Jatropha biodiesel and

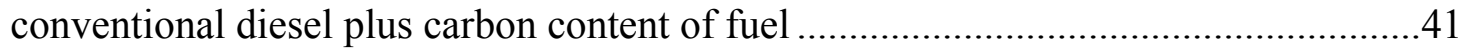

Table 17. Life cycle GHG process contributions by fuel blend ............................................42

Table 18. Contributions to net life cycle GHG emissions for biodiesel production from Jatropha (excludes vehicle operation) ...........................................................43

Table 19. Process contributions to life cycle GHG emissions for the production and distribution of diesel fuel (vehicle operation excluded) .......................................44

Table 20. Contribution by GHG to well-to-pump to net life cycle global warming potential ......44 
Table 21: Comparison of NEV (MJ/1,000 GTK) for the base case for each of the four transport modes evaluated in this study

Table 22. Well-to-pump NEV (MJ net energy value) for the base case scenario ........................46

Table 23. Net energy ratio evaluated at the point of refueling a vehicle (excluding vehicle operation).

Table 24. Comparison of net life cycle petroleum consumption and displacement intensities (kg crude oil/1,000 GTK) for the base case for each of four transport modes evaluated in this study

Table 25. Well-to-pump net petroleum consumption and displacement (g crude oil/MJ fuel delivered) for the base case scenario.

Table 26. Benchmarking the net life cycle GHG-emission results of the present study against results from other published studies

Table 27. Sensitivity scenario A - marginal land, low irrigation-input parameters

Table 28. Comparison of net life cycle GHG emission intensity $\left(\mathrm{kg} \mathrm{CO}_{2} \mathrm{e} / 1,000 \mathrm{GTK}\right)$ for sensitivity scenario A for each of four transport modes evaluated in this study...........53

Table 29. Comparison of NEV (MJ/1,000 GTK) for sensitivity scenario A for each of four transport modes evaluated in this study

Table 30. Comparison of net petroleum consumption and displacement intensity for sensitivity scenario A for each of four transport modes evaluated in this study....

Table 31. Sensitivity scenario B: marginal land, high cultivation maintenance-parameter inputs .

Table 32. Comparison of net life cycle GHG emission intensity $\left(\mathrm{kg} \mathrm{CO}_{2} \mathrm{e} / 1,000 \mathrm{GTK}\right)$ for sensitivity scenario B for each of four transport modes evaluated in this study.....

Table 33. Comparison of NEV intensity (MJ/1,000 GTK) for sensitivity scenario B for each of four transport modes evaluated in this study

Table 34. Comparison of net petroleum consumption and displacement intensity for sensitivity scenario B for each of four transport modes evaluated in this study....

Table 35. Sensitivity scenario C: good land, high cultivation maintenance-parameter inputs......58

Table 36. Comparison of net life cycle GHG emission intensity $\left(\mathrm{kg} \mathrm{CO}_{2} \mathrm{e} / 1,000 \mathrm{GTK}\right)$ for sensitivity scenario $\mathrm{C}$ for each of four transport modes evaluated in this study

Table 37. Comparison of net NEV (MJ/1,000 GTK) for sensitivity scenario C for each of four transport modes evaluated in this study

Table 38. Comparison of net life cycle GHG emission intensity for sensitivity scenario C for each of four transport modes evaluated in this study

Table 39. Sensitivity scenario D — centralized biodiesel production-input parameters

Table 40. Comparison of net life cycle GHG emission intensity $\left(\mathrm{kg} \mathrm{CO}_{2} \mathrm{e} / 1,000 \mathrm{GTK}\right)$ for sensitivity scenario $D$ for each of four transport modes evaluated in this study .....62

Table 41. Comparison of NEV (MJ/1,000 GTK) for sensitivity scenario D for each of four transport modes evaluated in this study

Table 42. Comparison of net petroleum consumption and displacement intensity for sensitivity scenario D for each of four transport modes evaluated in this study

Table 43. Comparison of net life cycle GHG emission intensity $\left(\mathrm{kg} \mathrm{CO}_{2} \mathrm{e} / 1,000 \mathrm{GTK}\right)$ for the biomass offset heat sensitivity scenario for each of four transport modes evaluated in this study

Table 44. Comparison of NEV (MJ/1,000 GTK) for the biomass offset heat sensitivity scenario for each of four transport modes evaluated in this study 
Table 45. Comparison of net petroleum consumption and displacement intensity for the biomass offset heat sensitivity scenario for each of four transport modes evaluated in this study

Table 46. Local sensitivity coefficient of selected input parameters for net life cycle GHG emissions .

Table 47. Local sensitivity coefficient of selected input parameters for net energy value (NEV)

Table 48. Local sensitivity coefficient of selected input parameters for net petroleum consumption intensity.

Table 49. Comparison of net life cycle GHG emission intensity $\left(\mathrm{kg} \mathrm{CO}_{2} \mathrm{e} / 1,000 \mathrm{GTK}\right)$ for the $\mathrm{N}_{2} \mathrm{O}$ volatilization rate sensitivity scenario for each of four transport modes evaluated in this study

Table 50. Comparison of net life cycle GHG emission intensity $\left(\mathrm{kg} \mathrm{CO}_{2} \mathrm{e} / 1,000 \mathrm{GTK}\right)$ for the biodiesel efficiency loss sensitivity scenario for each of four transport modes evaluated in this study

Table 51. Comparison of NEV (MJ/1,000 GTK) for the biodiesel efficiency loss sensitivity scenario for each of four transport modes evaluated in this study

Table 52. Comparison of net petroleum consumption and displacement intensity for the biodiesel efficiency loss sensitivity scenario for each of four transport modes evaluated in this study....

Table 53. Projected petroleum displacement for complete substitution of B20 produced under base case conditions for conventional diesel in the four transport modes analyzed in this study....

Table 54. Projected net life cycle GHG emission reductions for complete substitution of B20 produced under base case conditions for conventional diesel in the four transport modes analyzed in this study.

Table 55. Estimated amounts of biodiesel required to completely substitute B20 for all-petroleum diesel for the four transport modes analyzed in this study ....................88

Table A-1. Base case input parameters that have assigned values .........................................97

Table A-2. Calculated input parameters that have values determined by formulas based on other parameters

Table A-3. India Electricity Generation Custom Module

Table A-4. Indian Electricity Delivered Custom Module

Table A-5. Jatropha Seedling for Planting Custom Module.

Table A-6. Jatropha Plantation, Planted, India Custom Module

Table A-7. Jatropha Seeds Harvested from Plantation Custom Module

Table A-8. Jatropha Oil, at Extraction Facility, India Custom Module.

Table A-9. Biodiesel Production, Base-catalyzed Transesterification, India, at PlantCustom Module

Table A-10. Biodiesel Blending, India, at Processing Custom Module

Table A-11. Crude Oil at Indian Mix Custom Module.

Table A-12. Crude Oil Delivered to Refinery via Ocean Tanker, India Custom Module.

Table A-13. Indian Rail Transport Custom Module

Table A-14. India Road Transport Custom Module 


\section{Introduction}

At the behest of the Department of Energy's Office of Biomass Programs and in cooperation with Indian Oil Corporation Ltd. (IOC), the National Renewable Energy Laboratory (NREL) performed a life cycle assessment (LCA) of the use of biodiesel made from the seeds of the Jatropha plant grown in India and used in India's existing transport system. In 2003, the Planning Commission (2003) released a strategy document for increasing bio-fuel production in the country. One goal outlined in the strategy document is to use biodiesel to offset up to $20 \%$ of diesel consumption by 2012, with Jatropha curcas L. (Jatropha) identified as a favorable potential feedstock. With a projected diesel demand of almost 67 million metric tonnes by 2012, India would need to produce over 13 million metric tonnes of Jatropha biodiesel to offset $20 \%$ of diesel consumption, requiring over 11 million hectares of cultivated land (Planning Commission 2003). Given the scale of such a proposal and with the knowledge that biofuels have considerably different — and, in the case of India, more domestically focused — environmental impacts than petroleum, it is critically important to evaluate the life cycle performance of substituting Jatropha biodiesel for conventional diesel to determine if the desired environmental benefits are likely to be achieved. Other research has examined selected life cycle performance of substituting Jatropha biodiesel for conventional petroleum diesel. However, these studies either focus on conditions in non-Indian countries (Prueksakorn and Gheewala 2008 and Ndong et al. 2009) or focus on passenger car transport that is only a minor component of diesel fuel consumption in the Indian transportation sector (Reinhardt et al. 2007).

This study models Indian-specific Jatropha cultivation and processing conditions and evaluates potential impacts on sustainability and energy security across multiple transport modes that consume the majority of transport-related diesel fuel in India. The analyzed transport modes include road-freight transport via goods carrying trucks, road-passenger transport via buses, freight transport via rail, and passenger transport via rail. These transport modes were selected because they represent the majority of transport-sector diesel fuel consumption in India and can be readily compared using the common metric of gross tonne kilometers of transport $(\mathrm{GTK})^{3}$ to determine which mode provides greater environmental and energy security benefits. The study seeks (1) to determine the relative reductions in greenhouse gas (GHG) emissions and petroleum consumption for multiple biodiesel blends compared to petroleum diesel, (2) to project potential absolute reductions in each of the four analyzed transport modes for both the near term (year 2006) and future (year 2020), and (3) to evaluate multiple cultivation and processing scenarios in order to identify the parameters that are most critical to achieving sustainability and energy security goals.

\footnotetext{
${ }^{3}$ Gross tonne kilometers are calculated as the weight of the vehicle, passengers, and freight multiplied by the distance traveled. It can be used to compare transport modes that carry different cargo (freight or passengers) on a common basis.
} 


\subsection{Background}

Oil provides over $95 \%$ of the energy required for India's transportation sector, while domestic supplies provide only $22 \%$ of future projected demand (Planning Commission 2003). In 2003, the Planning Commission of the Government of India (Planning Commission) established the Committee on Development of Bio-Fuel to explore how India can use domestically produced ethanol and biodiesel blended with motor spirit (gasoline) and diesel, respectively, to reduce vehicle emissions, which adversely affect human health and the environment, and to decrease the country's reliance on petroleumbased fuels. Jatropha was selected as the most suitable for the production of biodiesel in India for its ability to thrive in a variety of agro-climatic conditions, low gestation period and high seed yield relative to other plants with oil-bearing seeds. In 2009, the Indian government released a National Policy on Biofuels calling for all transport fuels in India to contain at least $20 \%$ biofuels (Ministry of

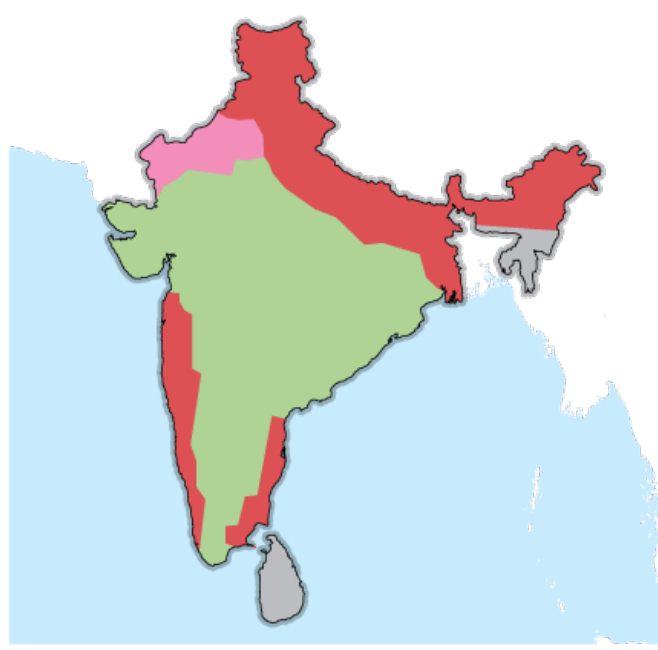

Figure 1. Jatropha cultivation zones

Green areas indicate high Jatropha cultivation potential in India. Red areas are fertile agricultural lands unlikely to be used for Jatropha cultivation and pink areas are deserts with poor growing conditions. Source: http://www.svlele.com New \& Renewable Energy 2009). It has been determined that biodiesel can be used in diesel engines at a blend of up to $20 \%$ (B20) without substantial engine modifications and generally results in reductions of hydrocarbon, carbon monoxide, particulate matter, and sulfur dioxide emissions (Planning Commission 2003). Figure 1 shows the preferred regions in India for Jatropha growth. Areas of the map highlighted in green are most likely to be targeted for Jatropha cultivation.

\subsection{Overview of India's Petroleum Consumption and Greenhouse Gas Emissions}

According to the Pew Center for Global Climate Change (2008), India emitted approximately 1,800 million metric tonnes of carbon dioxide equivalent $\left(\mathrm{mtCO}_{2} \mathrm{e}\right)$ in 2006 with an estimated $6 \%$ of emissions ( 110 million $\mathrm{mtCO}_{2} \mathrm{e}$ ) coming from the transportation sector. For comparison, the transportation sector in the United States in 2006 accounted for approximately $28 \%$ of national GHG emissions (U.S. Environmental Protection Agency 2009). The majority of India's transportation sector GHG emissions are from the combustion of refined petroleum products including diesel. As a whole, India consumed approximately 145 million metric tonnes of crude oil in 2006 with 110 million metric tonnes imported and 35 million metric tonnes produced domestically (International Energy Agency 2009). The transportation sector consumes approximately 36 million metric tonnes per year of refined petroleum products including diesel, gasoline, and kerosene (International Energy Agency 2009).

\subsection{Profile of India's Transportation Sector}

According to India's Ministry of Shipping, Road Transport, and Highways (MSRTH), India's transportation sector accounts for $6.4 \%$ of India's gross domestic product (GDP) with road transport accounting for $4.5 \%$ and rail transport contributing $1.2 \%$. Water and air transport each contribute only about $0.2 \%$ to overall GDP (MSRTH 2009). The road sector's contribution to 
national GDP is growing at a rate of $9.4 \%$ per year, outpacing overall GDP growth of $6.9 \%$ per year. The rail sector's contribution to GDP is growing at $6.8 \%$ per year, a similar rate to overall GDP growth (MSRTH 2009).

In 2006, more than 89 million motor vehicles were registered in India, and the overall compound annual growth rate for registered vehicles exceeded 10\% (MSRTH 2009). Approximately 72\% of registered vehicles in India are two-wheel vehicles and 13\% are four-wheel passenger cars. Only 5\% of registered vehicles are freight-carrying vehicles, and approximately $1 \%$ is buses (MSRTH 2009). While two-wheel vehicles and passenger cars comprise the majority of registrations, they primarily operate on gasoline (Singh et al. 2008) and are therefore not potential targets for biodiesel use. Singh et al. (2008) indicate that essentially all light-duty, medium-duty, and heavy-duty commercial vehicles in India operate on diesel fuel and that diesel fuel consumption has maintained a steady share of transportation sector fuel consumption at $83 \%$, as increasing demands for freight and passenger transport have offset reductions in relative percentages of vehicle registrations. This study focuses on goods carrying commercial vehicles and passenger buses to represent the segments of the Indian road transportation sector that are primarily responsible for diesel fuel consumption.

In 2006, road-passenger transport exceeded 4,200 billion passenger kilometers (pkm). Although two-wheelers and cars account for over $85 \%$ of vehicle registrations in India, bus transportwith over 990,000 registered buses (MSRTH 2009) — accounts for approximately 56\% of all road sector pkm (Sreenivas and Sant 2008). Indian buses can average up to $40 \mathrm{pkm} /$ vehicle kilometer (vkm) (Singh 2005), and they are used heavily in urban areas. Road-freight transport in 2006 reached nearly 660 billion GTK from the operation of 4.4 million registered goods-hauling vehicles (MSRTH 2009).

The rail sector in India, operated by Indian Railways (IR), is vital to the domestic transport of both passengers and freight. Approximately two billion liters of diesel fuel are consumed annually in the operation of almost 4,000 freight and passenger locomotives at a cost of almost US $\$ 1.3$ billion/yr (Kathpal 2008). In 2006, the rail sector accounted for approximately $40 \%$ of all freight transport in India with over 440 billion GTK transported and provided over 610 billion pkm of passenger transport. Indian Railways' locomotives operate using either electricity or diesel to provide the primary motive force with electricity primarily being used for urban and suburban passenger transport (Indian Railways 2008). This study focuses on the potential for use of biodiesel in diesel locomotives used for both freight and passenger transport and uses GTK as the common functional unit. Indian Railways' diesel locomotives were estimated to provide over 230 billion GTK of passenger transport and almost 320 billion GTK of freight transport in 2006 (Ministry of Railways 2008).

\subsection{System Description}

The following system descriptions are largely reprinted from Whitaker and Heath (2009) for the convenience of the reader. Minor updates have been made to reflect the expansion of scope from the rail sector to include road transport vehicles. 


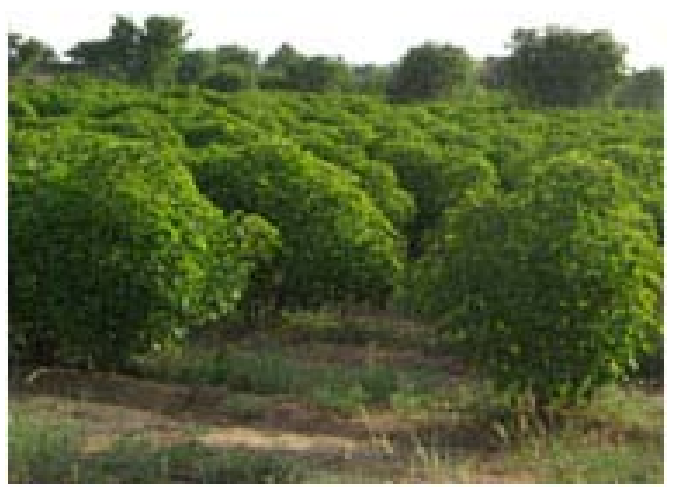

Figure 2. Jatropha curcas trees

Source: http://www.jatrophaworld.org

\subsubsection{Life Cycle of Jatropha Biodiesel- General Description}

Biodiesel production begins with the cultivation of Jatropha (Figure 2), a small tree or large shrub that grows to an average height of 3-5 meters (with heights exceeding 7 meters in optimal conditions) and bears fruits containing seeds rich in non-edible oil suitable for conversion to biodiesel. Jatropha can grow in a variety of environmental conditions, including poor soils and high or low rainfall, but generally prefers the heat of the tropics and subtropics. Jatropha can grow without irrigation in rainfall conditions ranging from 300 to $3,000 \mathrm{~mm} / \mathrm{yr}$ (Achten et al. 2008) and grows in the wild throughout India, with a life expectancy of 50 years.

For commercial production, Jatropha is grown in plantations with tree densities ranging from 1,100 to 2,500 trees/hectare (Achten et al. 2008 and Lele 2008a). Jatropha is often established through the planting of seedlings grown at nurseries in plastic bags (Achten et al. 2008). Irrigation and fertilization requirements are highly dependent on location-specific conditions. Even under adequate rainfall, irrigation may be required for the first three years to facilitate plantation establishment (Reinhardt et al. 2008). If fertilization is required, nitrogen and phosphorus tend to be the nutrients of greatest need (Achten et al. 2008). In India, Jatropha fruit (Figure 3) can be harvested at least once per year, often using human labor (Lele 2008a).

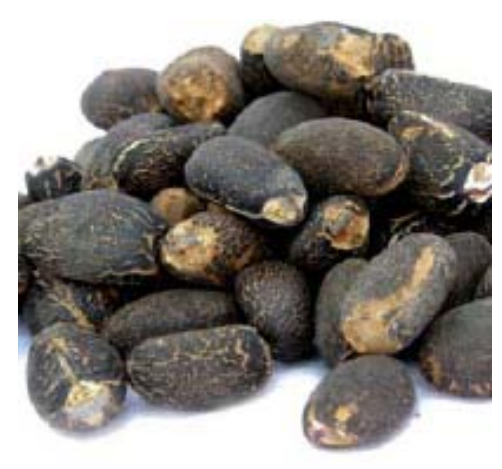

Figure 4. Jatropha seeds

Source: Lele 2008a
Once harvested, the Jatropha fruit is de-husked to isolate the oilbearing seeds (Figure 4) through use of either a mechanical decorticator or manual labor. The husks can be collected as a coproduct and used to generate energy (heat or electricity) by combustion. Chemicals in the seed render the oil toxic to humans and animals but appropriate for conversion into biodiesel. The yield of Jatropha trees is highly uncertain. According to Achten et al. (2008), reliable data on the anticipated dry Jatropha seed yield per hectare per year for a given set of environmental conditions and inputs do not exist. However, Achten and colleagues suggest 4-5 metric tons (tonnes) of dry seed per hectare per year as a reasonable yield estimate for a well-managed plantation with favorable environmental conditions. 
Jatropha seed oil content can range from an average of $25-40 \%$ oil by mass (Sarin 2008a), which can be extracted using either mechanical systems such as a screw press or chemical-based processes such as solvent extraction (Adriaans 2006). Solvent extraction is more efficient (90$99 \%$ oil extraction) but also more expensive and is only economical for commercial-scale processing. Hexane is the primary solvent used for commercial extraction at this time (Adriaans 2006). Seed cake remaining after oil extraction is rich with nutrients and can be returned to the field as fertilizer with an average nitrogen : phosphorous : potassium (NPK) ratio of 40:20:10 (Prueksakorn and Gheewala 2008).

To produce a usable biofuel, Jatropha oil is transesterified to biodiesel and glycerine using methanol as the alcohol and either sodium hydroxide $(\mathrm{NaOH})$ or potassium hydroxide $(\mathrm{KOH})$ as a base catalyst. Glycerine is a marketable co-product whose value depends on the quantity available from alternative suppliers, its purity, and other attributes such as its odor. (Glycerine produced as a co-product of biodiesel production is known to have a strong odor, which can affect its marketability). The Indian Oil Corporation, Ltd. has suggested that the market is robust in India for glycerine obtained from biodiesel production, as a substitute for petroleum-based chemicals in the production of some plastics, pharmaceuticals, and cosmetics, though that may not be the case in other countries or at all times (Sarin 2008c).

Biodiesel can be used in both heavy-duty road vehicles such as buses and trucks and in locomotives. Biodiesel is initially being used in India in blends of B5, B10, and B20, and it has shown no adverse impacts on engine performance in blends of up to B20 in Indian Railways trials (Kathpal 2008). A literature review of biodiesel blends in diesel engines used for road transport by Basha et al. (2009) has also shown no adverse impact on engine performance. Biodiesel can be blended with diesel either at regional storage or at the point of fueling.

\subsubsection{Analysis Approach}

Several options were available for developing a comparative analysis of Jatropha biodiesel and conventional diesel in India based on scenarios for cultivation, extraction, processing, and use in transport vehicles. One option was to form a base case scenario from parameters that were independently averaged based on point estimates and ranges reported in the literature. A motivation for using this approach is to attempt to make the scenario under consideration as generalizable as possible. However, because many of the parameters are causally related, a scenario comprised of averages formed independently could be implausible. Therefore, the authors chose an alternative approach. A narrative that coherently links all key parameters into a base case scenario was developed. The robustness of this base case scenario was tested by (1) a thorough sensitivity analysis that independently examines reasonable alternative values of each parameter, and (2) reasonable and internally coherent alternative scenarios. Because so many key parameters, especially for Jatropha cultivation, depend on site conditions, the authors, following recommendations from the IOC, selected a particular region of India for consideration, matching certain agronomic parameters to the typical conditions of that location. ${ }^{4}$ The following subsections describe the most important aspects of the base case scenario for both Jatropha biodiesel and conventional diesel production and use in Indian transport vehicles.

\footnotetext{
${ }^{4}$ Specifying a region within India is different from specifying a particular site. Knowledge of site-specific conditions would allow for determination of the impacts of changing an existing land use to one of Jatropha cultivation, which remains unknown with the current approach.
} 


\subsubsection{Jatropha Biodiesel Base Case Scenario Description Jatropha Cultivation}

As Jatropha can be grown throughout India (Figure

1), and numerous production pathways are possible, a base case narrative was developed to guide the analysis. The base case narrative is based on guidance from the IOC regarding likely future development scenarios (Sarin 2008a,b,c,d,e).

This analysis assumes that the Jatropha trees are grown on a 50,000-hectare plantation for 20 years in the Raipur area of the Chhattisgarh state of India where the average annual rainfall is $1,385 \mathrm{~mm} / \mathrm{yr}$. The state of Chhattisgarh, identified in red in Figure 5 , falls within the prime Jatropha cultivation zones of India displayed in Figure 1. Seeds are manually harvested at the plantation and are transported via truck to a hypothetical oil extraction facility in Raipur. Raipur is the capital of Chhattisgarh, is well connected to the region via road and rail, and is one of India's fastest growing industrial cities.

\section{Summary of Jatropha Cultivation and Processing Plant Assumptions}

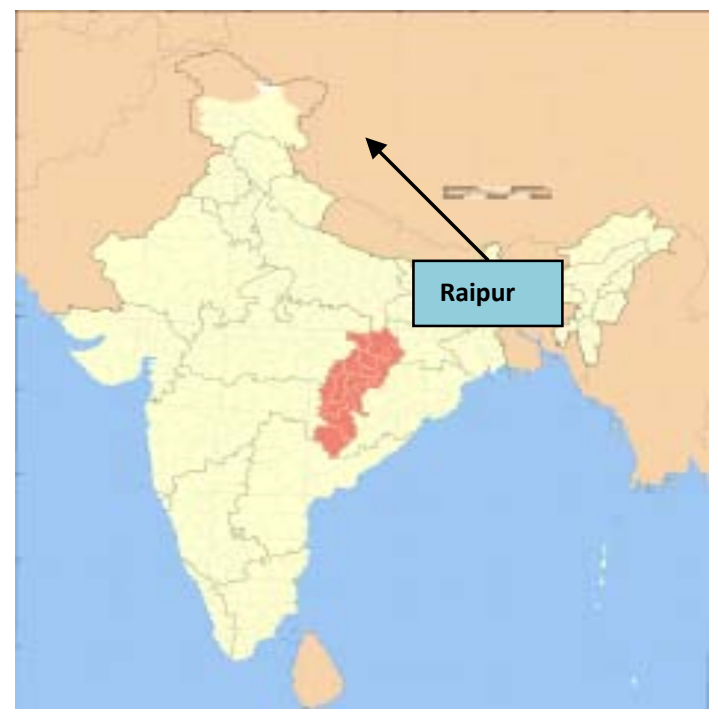

Figure 5. Chhattisgarh state, India, with the location of the city of Raipur indicated.

$$
\begin{gathered}
\text { Source: } \\
\text { http://en.wikipedia.org/ } \\
\text { wiki/Chhattisgarh }
\end{gathered}
$$

The base case Jatropha cultivation and biodiesel processing characteristics are taken from the Planning Commission's (2003) assumptions used in its bio-fuels assessment report. These assumptions were used to calculate the base case results for both current conditions and for projected impacts in 2020. Sensitivity analyses in Section 7 of this report were used to evaluate changes to these assumptions including to critical parameters such as seed yield per hectare that are influenced by tree density and assumed yield per tree. The following is a list of some of the most important base case assumptions.

- Jatropha is cultivated via nursery.

- Jatropha is planted at a density of 2,500 trees/hectare.

- Quality of soils and agro-climatic conditions (e.g., temperature, rainfall) at the plantation site are average for the region.

- Jatropha plants reach maturity within three years of planting at which time full seed yield is expected.

- 1,500 grams of seed are harvested per tree per year at full yield, or 3.75 metric tons (tonnes) of seed/hectare-yr.

- Seed oil content is $35 \%$ by weight.

- Solvent extraction efficiency is $91 \%$.

- Jatropha oil recovery efficiency is $32 \%$ (i.e., $35 \%$ oil content multiplied by $91 \%$ recovery efficiency).

- According to the above conditions, $3.125 \mathrm{~kg}$ seed is required to produce $1 \mathrm{~kg}$ Jatropha oil. 
- Assumed oil recovery efficiency yields 1.2 tonnes of Jatropha oil per hectare-yr.

- Anticipated Jatropha oil recovery for the full plantation is 60,000 tonnes/yr.

\section{Jatropha Oil Extraction}

This analysis assumes that the oil extraction facility has a capacity of 200 tonnes oil/day, giving it the ability to process up to 625 tonnes of seeds/day in a continuous solvent extraction process with $91 \%$ extraction efficiency. According to Adriaans (2006), continuous solvent extraction of Jatropha oil requires processing of at least 200 tonnes of seeds/day to be economical. Solvent extraction plants can process up to 4,000 tonnes/day (Adriaans 2006), which means the base assumption of a 625-tonnes/day capacity is well within the current technology range. The solvent used in the process is hexane as it is currently the only solvent used commercially on a large scale (Adriaans 2006). Given the size of the facility, the extraction is assumed to be continuous (Figure 6) as opposed to "batch." Not all of the individual processes shown in Figure 6 are specifically modeled in this analysis, though their impacts and results are included in summary fashion.

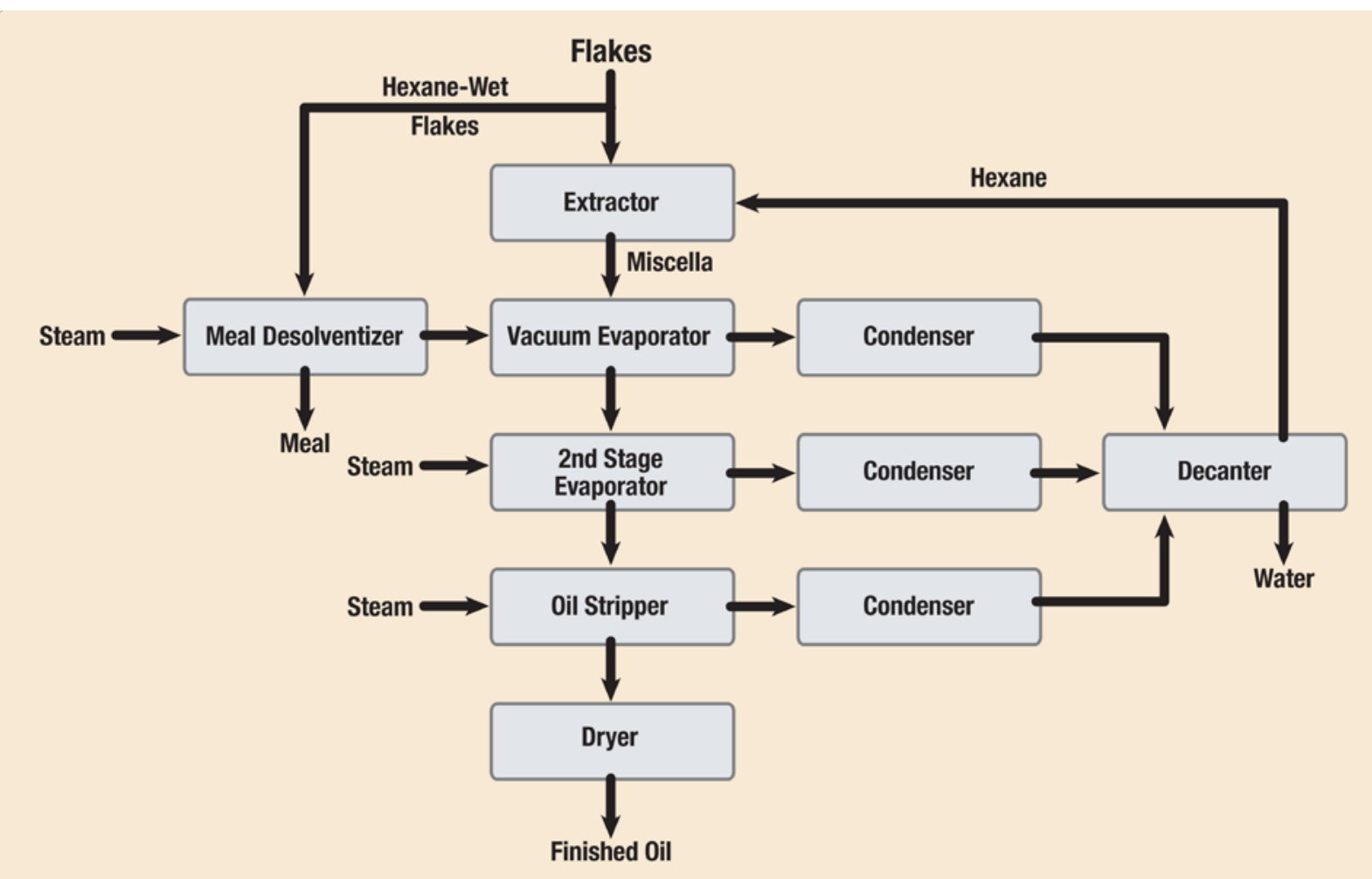

Figure 6. Schematic for continuous solvent oil extraction

Source: Adriaans (2006)

\section{Biodiesel Production via Jatropha Oil Transesterification}

The Jatropha oil extraction facility is co-located with the biodiesel transesterification plant for logistical reasons. This study assumes both are located in Raipur. The transesterification unit capacity is assumed to be 100,000 tonnes of biodiesel/yr with $95 \%$ efficiency for conversion of Jatropha oil to biodiesel. Operated continuously, the 200-tonne/day, oil-extraction unit would generate 73,000 tonnes of Jatropha oil per year. The excess plant capacity could be used by other 
extraction units in the area to process Jatropha oil generated. The transesterification process is assumed to be base-catalyzed using potassium hydroxide with methanol as the alcohol.

\section{Vehicle Operation}

As per discussions with the IOC (Sarin 2008b) and statements by IR (Kathpal 2008), the base case compares blends of B5, B10, and B20 to conventional diesel. Results for B100 are also presented to facilitate projections for other possible biodiesel blends. The base case assumes that the vehicles are fueled in Bhilai, 20 kilometers from Raipur, and that the biodiesel blending with petroleum diesel occurs at the IOC's Bhilai petroleum depots. The base case analyzes the fuel requirements for 2 billion gross tonne-kilometers (GTK) of vehicle travel over 20 years. An IR study found a negligible effect on volumetric fuel consumption for locomotives operated on B5, B10, or B20 (Kathpal 2008). Basha et al. (2009) found similar results for the road sector. The base case assumes no fuel consumption differential from the use of biodiesel blends compared to diesel, while the sensitivity analysis tests for the impacts of reductions in biodiesel fuel consumption efficiency with increases in biodiesel percentages. Assumed fuel consumption efficiencies for each vehicle transport mode are listed in Table 11. This study assumes that the combustion of biodiesel results in no net carbon dioxide emissions; carbon sequestered from the atmosphere during the growth of the Jatropha biomass offsets the carbon dioxide emissions from combustion of the same biomass. This concept is described further in Section 3.

\subsubsection{Reference System-Petroleum Diesel Production and Distribution}

As biodiesel is used primarily in blended applications with conventional, petroleum-based diesel (diesel), the diesel life cycle serves a dual purpose in this analysis. First, the $100 \%$ diesel

scenario serves as a benchmark against which the biodiesel blends (B5, B10, B20, and B100) are compared. Second, the entire diesel life cycle is contained within the blended biodiesel life cycle as even in the highest blending scenario (B20), 80\% of the fuel comes via the diesel pathway.

Crude oil used in India is of both domestic and foreign origin. For the base case, foreign oil is assumed to be extracted from Saudi Arabia (U.S. Energy Information Administration 2007a) and transported to the Visakhapatnam Oil Refinery (VIZAG) on the east coast of India near the Bay of Bengal (Figure 7). Domestic oil is assumed to be extracted from the Bombay High oil field off the west coast of India near Mumbai and transported via oil tanker to VIZAG. Refined diesel is transported from VIZAG to the oil depots in Bhilai near Raipur via rail for fueling transport vehicles at the Bhilai depots. A complete set of detailed data regarding the operations of the VIZAG refinery was not made available in time for completion for this study. However, a preestablished diesel fuel-refining module based on Western European average refining impacts from the ecoinvent 2.0 database (Swiss Centre for Life Cycle Inventories 2008) was used as a substitute with customized factors for electricity and thermal energy consumption based on VIZAG operating conditions (Hindustan Petroleum Corporation Limited 2008). If the Western European refinery operates more efficiently than the Indian refinery, results may be biased in favor of the diesel system. If, however, tighter environmental regulations result in the Western European refinery using more energy for fuel processing, results may be biased in favor of the biodiesel system. 


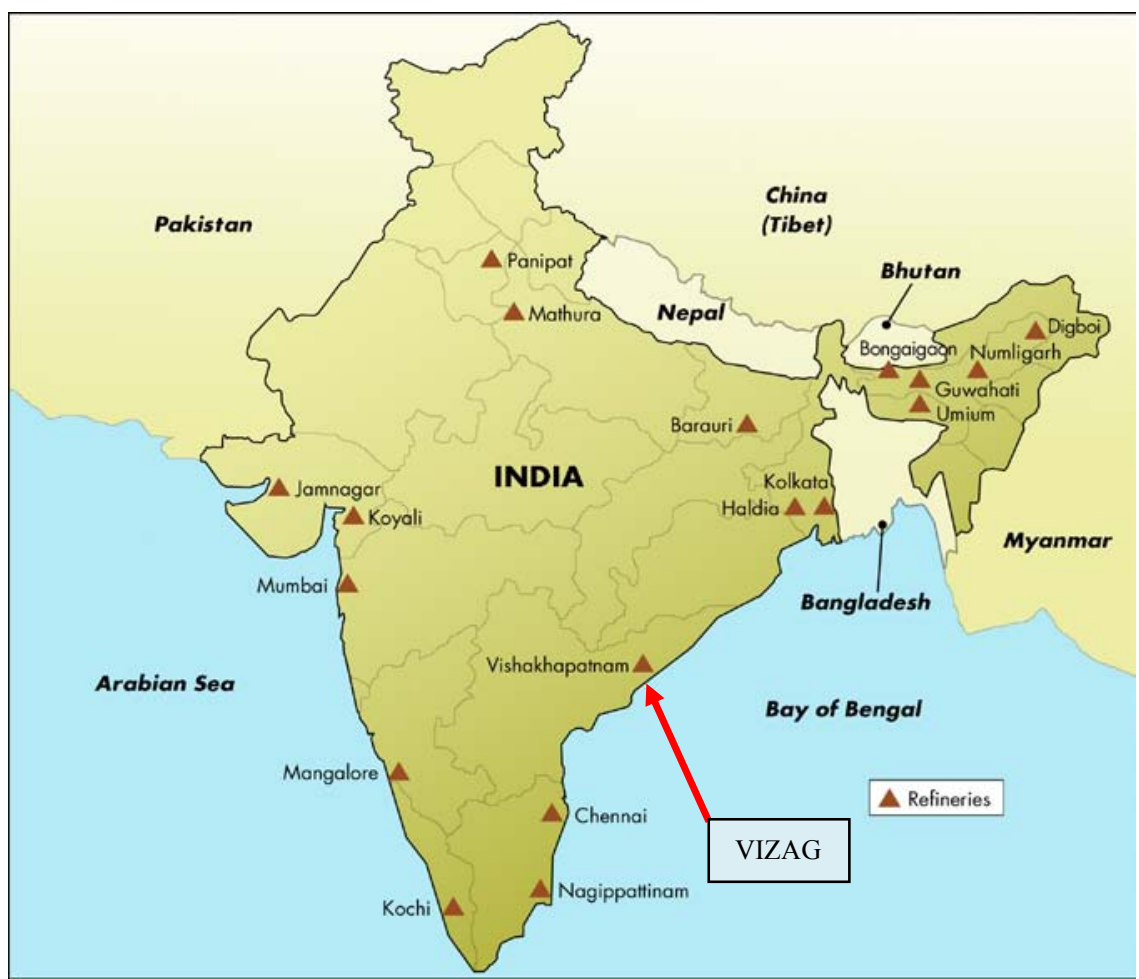

Figure 7. Visakhapatnam (Vizag) oil refinery

The Vizag oil refinery is located near the Bay of Bengal in eastern India. Source: http://www.mapsofindia.com/ 


\section{Methods}

\subsection{Life Cycle Assessment}

For a detailed description of life cycle assessment methodology and an explanation of how it is used in this study, see Whitaker and Heath (2009).

\subsection{Goal of the Study}

The purpose of this study is to compare the environmental impacts of using Jatropha biodiesel for road and rail transport in India with a baseline of conventional petroleum diesel use. The methodology used in this study is consistent with that described by the ISO 14044:2006 standards for LCA, and particularly those standards that cover inventory analysis (International Organization for Standardization 2006). The study is intended to lend guidance regarding the potential impacts of a significant increase in biodiesel production from Jatropha plants to offset a portion of the diesel fuel being used in the Indian transport system. LCA is used to evaluate the relative impacts throughout the life cycle phases, including resource extraction, crop cultivation, processing, and use in order to develop as complete a picture as possible of the likely impacts. The study also seeks to identify which key parameters and uncertainties are most likely to influence the conclusions of the study. The intended audience includes policy makers, industry executives, academic researchers, and any interested members of the public.

\subsection{Scope of the Study}

The scope of this study is the evaluation of the production of conventional petroleum diesel and the production of biodiesel from Jatropha for use in the road and rail transportation sectors of India. The analyzed vehicles include heavy-duty long distance cargo trucks representing "roadfreight," passenger buses representing "road-passenger," IR cargo trains representing "railfreight," and IR passenger trains representing "rail-passenger." The functional unit for the study is 1,000 GTK of transport. GTK includes both the weight of the train and the weight of any passengers or cargo on board. The functional unit assumes that the primary goal of the Indian transportation systems is to move passengers or cargo and that diesel and biodiesel should be evaluated in terms of their ability to provide that function. An overview of the processes included in the system evaluations are detailed in Figure 8 and Figure 9. The diesel and biodiesel production pathways are evaluated beginning with resource extraction, through transportation and processing, to use in transport vehicles.

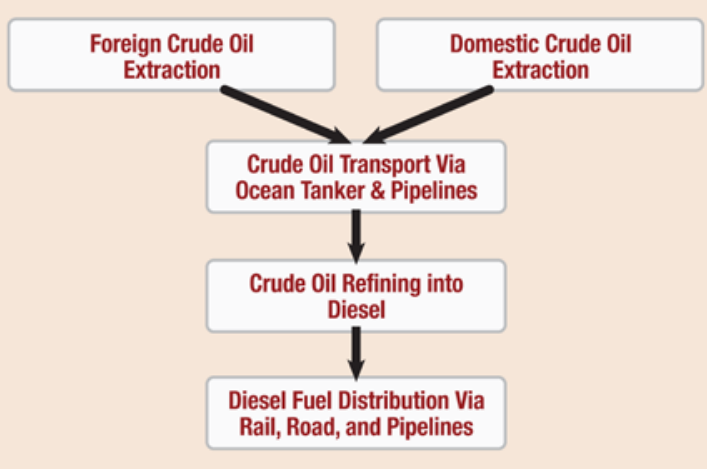

Figure 8. Petroleum diesel life cycle process map 
The diesel life cycle is required for analyzing the combustion of both conventional petroleum diesel and blended biodiesel in transport vehicles.

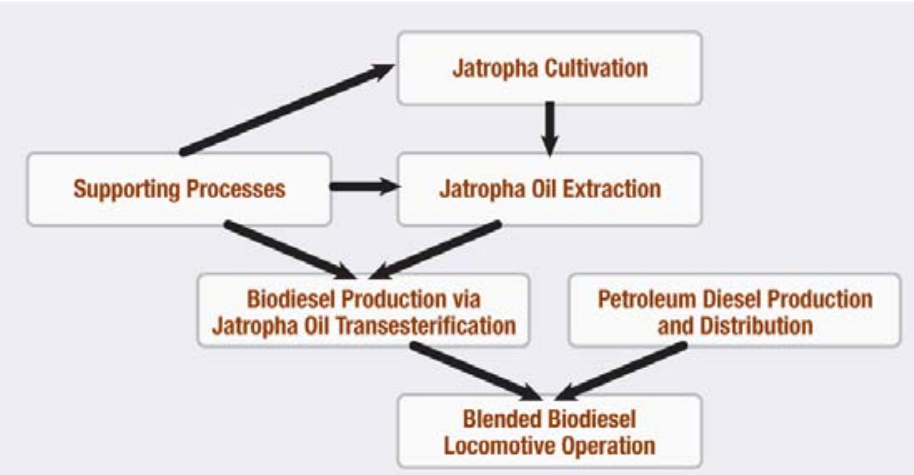

Figure 9. Blended biodiesel life cycle process map

The entire petroleum diesel production and distribution life cycle outlined in Figure 8 is contained in the blended biodiesel life cycle. Supporting processes include Indian transportation systems and electricity generation, transmission and distribution.

\subsection{System Boundaries}

This study analyzes both petroleum-diesel and biodiesel production and use pathways in India. It identifies resource consumption, energy use, and emissions for the following life cycle stages and sub-processes:

1. Petroleum diesel production and distribution (Reference System)
A. Foreign and domestic crude oil extraction
B. Crude oil transport
C. Crude oil refining into diesel fuel
D. Diesel fuel distribution for direct use and for blending with biodiesel

2. Jatropha cultivation
A. Seedling production and planting
B. Plantation operation and management, including harvesting of tree trimmings for use in combustion for process heat or electricity generation
C. Seed harvesting and transport to extraction facility

3. Jatropha oil extraction
A. Separation of seeds from husks with husks later used in combustion for process heat or electricity generation
B. Solvent-based extraction of oil
C. De-oiled seed cake use as fertilizer substitute

4. Biodiesel production via Jatropha oil transesterification

A. Base-catalyzed transesterification to biodiesel 
B. Transport of biodiesel for blending with petroleum diesel

C. Co-production of glycerol, which is later refined to glycerine

5. Vehicle operation
A. Vehicle operation on conventional petroleum diesel
B. Vehicle operation on blended biodiesel

6. Supporting processes

A. Indian transportation vehicles and infrastructure

B. Indian electricity and transmission and distribution infrastructure

C. Local generation of steam for use in Jatropha oil extraction and biodiesel transesterification processes

While the amortized impacts of manufacturing, assembling, and constructing infrastructure related to most processes are included in the analysis, railroad and road construction and related equipment infrastructure are omitted because the existing rail and road systems are assumed to be used. Operation of the vehicles (road and rail, freight and passenger) is included as the use phase of the study for both the petroleum-diesel and biodiesel pathways.

The geographic boundary for the study is India, except in as much as resources are extracted and transported to India from other countries.

The system vintage boundary for the study is set for present day technologies and systems. No efforts are made to project future technology advances. The most recent, quality data are used whenever possible.

Impacts are evaluated over a 20 -year timeframe, assuming 2 billion gross tonne-kilometers (GTK) of vehicle travel during that period. The selection of timescale should not significantly affect results as the time scale is consistent between the diesel and biodiesel systems and the results are normalized by 1,000 GTK. The 20-year period is consistent with analyses conducted in other studies (Reinhardt et al. 2007, Prueksakorn and Gheewala 2008, Whitaker and Heath 2009).

\subsection{Allocation Procedures}

Many options are available within LCA for the allocation of impacts (Scientific Applications International Corporation 2006). Allocation is necessary when a process produces more than one valuable product. For example, the extraction of Jatropha oil from the seeds produces two valuable products: Jatropha oil and Jatropha seed cake. The Jatropha oil is processed into biodiesel while the seed cake can be used in the fields as fertilizer, thus offsetting some chemical fertilizer requirements. It would be incorrect to assign all of the impacts associated with the energy and materials required to extract the oil to the Jatropha oil when the seed cake is also a valuable product. Allocation procedures typically divide process impacts among co-products using mass, energy, or economic value as the metric.

While each of these allocation procedures has its merits, the preferred methodology for LCAs is system boundary expansion where all process impacts are included but credits are taken for the 
impacts that are avoided by the production and use of the co-product (International Organization for Standardization 2006). In the case of oil extraction, the full process impacts are included in the analysis but credit is taken for the impacts that are avoided because the chemical fertilizer does not have to be produced because the seed cake is used in the fields. Other system boundary expansions considered in this study include (1) biomass from pruning Jatropha plants and using Jatropha fruit husks to generate electricity that offsets the Indian grid electricity, (2) biomass combusted to generate process heat, and (3) glycerol produced during transesterification being refined to glycerine for use in offsetting synthetic glycerine production.

\subsection{Impact Categories}

The study focuses on three primary impact categories:

1. Greenhouse gas emissions from all GHGs identified and characterized by the Intergovernmental Panel on Climate Change (IPCC) are considered cumulatively and weighted according to their 100-year global warming potential relative (GWP) to $\mathrm{CO}_{2}$, in metric tonnes of carbon dioxide equivalent $\left(\mathrm{mtCO}_{2} \mathrm{e}\right)$. The GWPs of the GHG emissions are calculated according to the IPCCs Fourth Assessment Report (2007) as detailed in Table 1.

2. Net energy value is evaluated by subtracting the net cumulative energy demand of the system from the energy delivered to the transport vehicles in the form of fuel energy (Farrell et al. 2006). All types of energy (e.g. fossil, nuclear, and renewable) along with credits for the use of biodiesel system co-product offsets are accounted for in the cumulative energy demand calculation. Net energy ratio, calculated as the fuel energy delivered divided by cumulative energy demand, is also briefly discussed for comparison to the Jatropha biodiesel rail-sector results (Whitaker and Heath 2009) and to other biodiesel analyses.

3. Net petroleum displacement is tracked in terms of reduced crude oil consumption for the analyzed biodiesel blend relative to the reference conventional petroleum diesel system.

Table 1. Global warming potentials (relative to $\mathrm{CO}_{2}$ ) of a subset of the greenhouse gases evaluated in this study (Source: IPCC 2007)

\begin{tabular}{lr}
\hline Greenhouse Gas & Global Warming Potential \\
\cline { 2 - 2 } $\mathrm{CO}_{2}$ & 1 \\
$\mathrm{CH}_{4}$ & 25 \\
$\mathrm{~N}_{2} \mathrm{O}$ & 298 \\
$\mathrm{HFC}-23$ & 14,800 \\
$\mathrm{HFC}-32$ & 675 \\
$\mathrm{HFC}-125$ & 3,500 \\
$\mathrm{HFC}-134 \mathrm{a}$ & 1,430 \\
$\mathrm{HFC}-143 \mathrm{a}$ & 4,470 \\
$\mathrm{HFC}-152 \mathrm{a}$ & 124 \\
$\mathrm{HFC}-227 \mathrm{ea}$ & 3,220 \\
$\mathrm{HFC}-236 \mathrm{fa}$ & 9,810 \\
$\mathrm{HFC}-4310 \mathrm{mee}$ & 1,640 \\
$\mathrm{CF}$ & 7,390 \\
$\mathrm{C}_{2} \mathrm{~F}_{6}$ & 12,200 \\
$\mathrm{C}_{3} \mathrm{~F}_{8}$ & 8,830
\end{tabular}




\begin{tabular}{lc}
\hline Greenhouse Gas & Global Warming Potential \\
\cline { 2 - 2 } $\mathrm{C}_{4} \mathrm{~F}_{10}$ & 8,860 \\
$\mathrm{C}_{5} \mathrm{~F}_{12}$ & 9,160 \\
$\mathrm{C}_{6} \mathrm{~F}_{14}$ & 9,300 \\
$\mathrm{SF}_{6}$ & 22,800 \\
\hline
\end{tabular}

Efforts were made to gather information on criteria pollutants, toxic air pollutants, and water consumption, but not enough India-specific, quality data were available throughout the life cycle processes to provide for a consistent and complete analysis of these impacts.

\subsection{Data Requirements}

Whenever possible, India-specific data from literature or the IOC are used for the base case analysis. When Indian data are not available, preference is given to regional studies from South or Southeast Asia with data gaps filled by established life cycle inventory (LCI) data from Europe and North America.

\subsection{Model}

The diesel and biodiesel systems are modeled using SimaPro 7.1 LCA Software from PRé Consultants (http://www.pre.nl/simapro/). SimaPro allows for the modeling of complex life cycles and the running of detailed sensitivity studies to determine the importance of parameter uncertainty and variability. Whenever possible, custom SimaPro process modules were developed to meet Indian-specific operating conditions. (Tables A3-A14 report the coding of the custom modules.) Modules within the SimaPro model are designed to define material, energy, and environmental inputs and outputs that are required for a specific process within the life cycle. For example, a module may define the electricity, steam, and water required for Jatropha oil extraction along with the required seeds that must be delivered from the plantation and the impacts of constructing the facility infrastructure.

When Indian data were unavailable or insufficient, gaps were filled using data from the ecoinvent v2 LCI database (http://www.ecoinvent.org/) included with the SimaPro software. While other LCI databases are available within and outside of SimaPro, to maintain consistency throughout the process, ecoinvent process modules were preferentially utilized because of the depth and breadth of the data modules and the consistent inclusion of infrastructure impacts. For these and other reasons, ecoinvent data are commonly used in LCAs by other researchers, improving comparability of our results to those. Infrastructure impact data are lacking for Indianspecific conditions and therefore are taken from the available data sets in ecoinvent. ecoinvent data are primarily focused on European conditions but contain many worldwide modules with data sets ranging from energy, building materials, and transport to chemicals, agriculture, and waste management. 


\subsection{Uncertainty}

As with all LCAs, this analysis encountered a great deal of uncertainty. Lloyd and Reis (2007) provide an excellent discussion of how uncertainty is characterized, addressed, and analyzed in LCA studies, along with the various types of uncertainty likely to be encountered. Uncertainty is particularly relevant to the outcomes of this study because the model is deterministic, using point estimates for all input parameters to generate single-point output estimates each time the model is run. Such a deterministic model that produces point estimates can yield a false perception of certainty in results that are generated from uncertain inputs. The authors' approaches for addressing uncertainty are discussed in the introduction to Section 7.

This study, which borrows the Lloyd and Reis typology, faces three primary types of uncertainty:

1. Parameter uncertainty - uncertainty in the numerical value assigned to a particular input parameter

2. Scenario uncertainty - uncertainty related to developing the analysis scenarios for the study, including selection of functional units, time horizons, and allocation procedures, use of co-products, and technology characterization

3. Model uncertainty - uncertainty in the mathematical relationships that drive the calculations in the model, which is designed to represent real world systems. Model uncertainty is minimized in this study for impacts such as GHG emissions from fuel combustion where the mathematical relationships between fuel consumption and GHG emissions are well established. The primary model uncertainty stems from random error and statistical variation related to the projected outputs of the Jatropha cultivation processes based on defined inputs.

Lloyd and Reis (2007) list seven major sources of uncertainty and variability that are applicable to each of the three types of uncertainty faced by this study. Below are highlighted the five major sources of uncertainty and variability in this study, with examples representing one or more of the three types of uncertainty.

1. Data unavailability: Comprehensive data sets detailing anticipated Jatropha seed and oil production given a particular set of environmental conditions and cultivation inputs are available mostly for site-specific studies and are not well characterized for general modeling of Jatropha cultivation.

2. Measurement uncertainty: Even when important parameters are identified and analyzed, precisely and accurately measuring their values may be difficult. Of particular relevance to this study is the accurate measurement of $\mathrm{N}_{2} \mathrm{O}$ release from nitrogen fertilizers as $\mathrm{N}_{2} \mathrm{O}$ is a potent GHG. Models can predict likely $\mathrm{N}_{2} \mathrm{O}$ release based on soil, climate, and fertilizer characteristics, but precise and accurate in situ measurements, on which the models are based, have proven extremely difficult to obtain.

3. Inherent variability: Many of the parameters in this study are strongly influenced by temporal and geographical conditions that vary over time, such as rainfall and the mix of foreign and domestic crude oil entering India. Moreover, while some of the parameters have well-established relationships, such as anticipated $\mathrm{CO}_{2}$ emissions from combusting a given amount of diesel fuel, several of the parameters in this study lack direct deterministic correlations. For example, seed and oil yields are challenging to predict 
with a great degree of certainty even if all environmental and human inputs and conditions of the system are known. These are examples of parameters that are inherently variable, with many other parameters exhibiting similarly variable numerical estimates.

4. Systematic errors and subjective judgment: Scenarios are set based on current processes worldwide and likely use of co-products. The market for biodiesel and Jatropha is immature in India, making it likely the included processes and product and co-product uses will change over time. Moreover, no technology advancement is assumed over the analysis lifetime, as predictions for the likely evolution of technology are not available.

5. Expert uncertainty and disagreement: There is no expert consensus on the most likely scenario for how Jatropha cultivation and transformation into biodiesel will develop in India. Multiple scenarios are plausible and vary greatly in terms of geographical location, production pathways, and co-product use even before the uncertainty of input parameters is included. The lack of expert agreement makes the development of a coherent analytical narrative challenging. As multiple competing scenarios could be proposed, the applicability of the results outside of the developed scenarios is uncertain.

\subsection{Sensitivity Analysis Approach}

Reasons to conduct a sensitivity analysis are at least twofold. First, sensitivity analysis can test the robustness of conclusions to parameter uncertainty and variability, assessed independently or in combinations. Second, sensitivity analysis can determine and rank the influence a given parameter has on model outputs. This study attempts to achieve both of these goals in its sensitivity analysis. It focuses on using scenario sensitivity analysis to evaluate alternative, plausible biodiesel production scenarios and on using parametric sensitivity analysis to assess the impact of key parameters on model outcomes.

Sensitivity analysis is distinct from uncertainty analysis. One method of uncertainty analysis propagates the uncertainty and variability of parameters through model calculations to estimate the uncertainty (error bounds) of model results. This study does not conduct a formal uncertainty analysis because the uncertainty and variability of parameter values for many parameters are unknown and the web of modeled processes is so complex that propagation is challenging. However, the study attempts to analyze both a plausible base case scenario and a series of coherent and plausible alternative scenarios that test the impact of changing multiple, related parameters on the model's outcomes. Additionally, the study selects ten individual input parameters to test the proportional impact of a consistent change in their input values on the outcomes of the model to determine a local sensitivity coefficient. 


\section{Base Case Assumptions}

Developing a coherent narrative for a base case analysis is among the most difficult tasks in an LCA of Jatropha biodiesel in India. As Achten and colleagues noted in their literature review, a quality set of data identifying anticipated Jatropha yields associated with specific environmental conditions and detailed irrigation and fertilization schedules does not exist (Achten et al. 2008). Experimentally developing such a coherent set of primary data inputs was outside the scope of this study. Consequently, the authors had to make many assumptions to define the scenarios and to estimate values for all parameters and scenarios. In addition, completing an LCA requires decisions about modeling approaches and calculation methods that do not necessarily have correct answers. To accurately interpret the results of an LCA, the analysts' assumptions and decisions must be transparent to the reader. Below, eleven major base case assumptions and modeling decisions for this study are outlined:

1. Fuel economy does not decrease with increasing biodiesel blends. According to initial Indian Railways (IR) trials of biodiesel in their locomotives, no difference in volumetric fuel consumption was observed for operation using B5, B10, or B20 compared to operation using conventional diesel (Kathpal 2008). Similarly, in a literature review of diesel engine performance on biodiesel blends, Basha et al. (2009) found no adverse impact on engine performance. If a fuel economy decrement is in fact experienced, then this study's impacts will have been underestimated. Therefore, the sensitivity analysis examines the impact of assuming a fuel economy decrement with the use of biodiesel of up to $8 \%$ for B100, scaling proportionally with the percent biodiesel blend (Van Gerpen 2009).

2. The biodiesel fuel combusted is assumed to have no $\mathrm{CO}_{2}$ emissions. At some point in this biofuel LCA, the carbon sequestered by the growth of the Jatropha trees must be credited as a reduction in GHG emissions from the biodiesel system. This study incorporates that credit by assuming an emission factor of zero for all biofuels combustion, including the portion of the transport vehicle fuel composed of biodiesel and the Jatropha biomass and combustion of prunings and clippings. The alternative assumption would be to account for carbon sequestration during the plantation operation phase. Data sets that define the rate at which Jatropha plants sequester carbon are not well established. Therefore, the authors chose to credit the sequestration at the point and time of use. The assumption of no net GHG emissions from combustion of biofuels is based on an assumption of complete combustion. Complete combustion means negligible emissions of other carboncontaining compounds such as carbon monoxide and methane along with other GHGs such as $\mathrm{N}_{2} \mathrm{O}$. Consequently, by first principles, the emission of carbon dioxide from the complete combustion of the biomass (in the form of solid or liquid fuel) must equal the carbon dioxide sequestered from the atmosphere. This assumption, which is also used by Ndong et al. (2009), should not bias results towards diesel or biodiesel, as a modification of this assumption would produce results within the error bounds of the study.

3. Potential land-use changes were not evaluated. Two categories of land use change are discussed here: direct and indirect. Direct land use change occurs on the land used to cultivate Jatropha. For instance, land is converted from fallow, marginal or active use to a Jatropha plantation. Indirect land use change occurs on other land, whether domestic or foreign, as a result of the displacement of products produced from the land that has been 
converted to a Jatropha plantation. For instance, if an edible oil seed crop is grown on land converted to a Jatropha plantation, then the reduced supply of oil seed could induce a different market actor to convert other lands to make up for the lost supply.

4. The location of the hypothetical Jatropha plantation considered in this study was not described in enough detail to ascertain its prior land use and aboveground and belowground carbon content. Therefore, determining net change in carbon content of the plantation site that is due to direct land-use change was not feasible. A significant limitation of this study is that the potential impacts of land-use change are not considered. Indirect (market-mediated) land-use change is not likely to be strongly linked to Jatropha production under current plans, which envision previously abandoned agricultural or otherwise degraded lands as Jatropha production zones (India Planning Commission 2003; Padma 2008). However, conversion of those lands to Jatropha production could result in greater, equal, or lesser soil carbon sequestration depending on the level of vegetation of the previous sites (Reinhardt et al. 2008). Consideration of the impact of this latter, so-called direct land-use change could alter the results presented in this study, though the direction and magnitude of difference from this study's estimates are unknown because such a determination requires site-specific inputs, which this study does not provide.

The carbon emissions from direct land-use change could be zero, small or significant, and could be either positive or negative, depending on the prior land use. According to a global market study on Jatropha (Global Exchange for Social Investment (GEXSI) 2008), $60 \%$ of identified Indian Jatropha projects cultivate the plants either wholly or partially on lands that are not suitable for agricultural production. Former land use for Jatropha project sites throughout Asia include 54\% no use/wasteland, 42\% non-food agricultural land, $0.4 \%$ primary forest, and $4 \%$ secondary forest; no lands used for food production are currently being targeted (GEXSI 2008). Locating Jatropha projects primarily on wastelands or agricultural lands that are not suitable for food production should minimize negative GHG-emission impacts from indirect land-use change by not displacing food production and may even provide a net GHG-emission benefit if non-vegetated land or land with a low soil carbon content is populated with Jatropha trees. If wastelands are used, soil carbon could be reasonably anticipated to increase after conversion to Jatropha plantation. Moreover, a bounding estimate based on data from Reinhardt et al. (2008) projects that the maximum direct land-use change GHG emissions would equate to approximately the following percentages of total 20-year net life cycle GHG emissions for the analyzed transport modes: $+0.25 \%$ for passenger-road transport, $+0.33 \%$ for freight-road transport, $+1.0 \%$ for passenger-rail transport, and $+1.6 \%$ for freight-rail transport. (See Section 8.1 for further discussion of this bounding estimate.)

The authors believe that the omission of land-use change impacts from the GHGemission analysis in this study does not significantly bias the results in favor of Jatropha biodiesel production based on 1) the previous land use characteristics of current Jatropha projects in the region, 2) the stated intention of the Planning Commission (2003) and Ministry of New \&Renewable Energy (2009) to focus Jatropha production on degraded lands, and 3 ) the bounding estimate generated using data from Reinhardt et al. (2008). 
5. A 20-year time horizon is assumed. A time horizon of greater than one year is required to analyze Jatropha biomass systems in order to include upfront activities such as plowing and irrigating the land for planting and the time required for Jatropha plants to mature. The duration of the life cycle should not bias results as most results are normalized to the functional unit (1,000 gross tonne kilometers) for reporting. A 20-year time horizon is well within the lifetime of most pieces of infrastructure in the study and is the value used in comparable studies (Reinhardt et al. 2007; Prueksakorn and Gheewala 2008). However, technological innovations will likely occur over this period, particularly for a nascent industry like biodiesel production in India. These potential innovations are not accounted for in the study, and if any were to occur, would lead to the results of this study being an underestimation of the life cycle impacts.

6. Jatropha plants receive $100 \%$ of their total required annual water, and $20 \%$ of the required water is supplied by irrigation. Data on the required irrigation for Jatropha trees is limited and not well coordinated with projected seed yield or with specific agroclimatic conditions. However, according to GEXSI (2008), more than $60 \%$ of Indian Jatropha projects report using some form of irrigation. Therefore, the authors chose to include irrigation in the baseline scenario. To calculate the amount of irrigation water required each year, data from Kheira and Atta's (2008) study on the response of Jatropha to water deficits is used. These data include the average weekly water consumption of Jatropha during the growing season and the average length of the growing season including initial development, flowering, and harvest stages. The authors assume that the combination of irrigation and rainwater meets $100 \%$ of Jatropha's annual water needs, with $20 \%$ of the water supplied via irrigation to meet time-specific water requirements. The sensitivity analysis tests scenarios for no irrigation and for up to $40 \%$ of water demand being met with irrigation. This irrigation-requirement calculation methodology is one of the major enhancements to the LCA model represented in Whitaker and Heath (2009).

7. Irrigation is assumed to be required for only the first three years of cultivation. Reinhardt and colleagues (2008) suggest that irrigation is only required during the establishment period of the plantation, which they report as three years. If irrigation is necessary for longer than three years, the impacts estimated in the base case scenario will be underestimated. The sensitivity analysis evaluates the impacts of requiring irrigation each year for the full life cycle.

8. Initial tree density is 2,500 trees/hectare in a $2 \mathrm{~m} \times 2 \mathrm{~m}$ planting grid. Tree planting densities reported in the literature range from 1,100 to $2,500+$ trees per hectare with the appropriate planting density largely dependent on local conditions. The Planning Commission (2003) uses 2,500 trees/hectare as the density for its calculations, which is taken as the base case assumption for this study. This important assumption will tend to increase both seed and biomass yields per hectare compared to cases of lower densities reported in the literature, benefiting the biodiesel system in comparison to the diesel reference system.

9. No pesticides, insecticides, or herbicides are applied to the crops. Some literature suggests that the use of protective chemicals on the trees may not be necessary (Reinhardt et al. 2008; Prueksakorn and Gheewala 2008) in part because of the toxic nature of the plant. Other studies have cited pests that do affect Jatropha crop yields (Lele 2008a). 
Because data sets recommending the appropriate amounts of chemicals to apply over tree life cycle are not well developed, this study assumes no protective chemicals are necessary. This assumption would lead to underestimated impacts for biodiesel production if protective chemicals were in fact necessary, though the degree of underestimation is likely not significant.

10. Seed cake is used to offset fertilizer use on the plantation. Jatropha seed cake has multiple potential uses once the oil has been extracted. This study assumes the seed cake is returned to the plantation to offset an amount of NPK fertilizer equal to the nutrient content of the seed cake. An alternative use of the seed cake-combustion to produce useable heat or power-is not considered.

11. Biomass removed from the plantation is combusted to generate electricity. Biomass removed from the plantation via pruning and clipping is assumed to be combusted to generate electricity (Reinhardt et al. 2008). The electricity generated from the plantation biomass offsets Indian grid electricity. Because system boundary expansion (as outlined in Section 4) is used to account for environmental burdens from co-products, no allocation of the environmental burdens of Jatropha tree cultivation were assigned to the removed biomass. No $\mathrm{CO}_{2}$ emissions are assumed for the biomass combustion to account for the credit that should be given for $\mathrm{CO}_{2}$ sequestration during Jatropha cultivation. Efficiency of conversion from biomass combustion to electricity generation is assumed to be 25\% (U.S. Climate Change Technology Program 2005). An alternative assumption tested in the sensitivity analysis is that the energy produced by combusting the biomass offsets heat required in a local industrial process.

12. Adequate markets exist for glycerine. This study does not conduct a market analysis to evaluate the potential for the sale of glycerine produced as a co-product of Jatropha biodiesel production to offset synthetic glycerine production. The base case and sensitivity scenario results assume that such a viable market exists based on statements by the Indian Oil Corporation (Sarin 2008c). Eliminating the co-product credit for glycerine diminishes the sustainability and energy security benefits analyzed in this study but does not change the conclusions regarding the comparison of the impacts of Jatropha biodiesel production and use to conventional petroleum diesel production and use. For example, removing the credit for offsetting synthetic glycerine production from the base case analysis decreases the GHG emission reductions for B100 compared to petroleum diesel from $72 \%$ to $60 \%$. Thus, the conclusion that the production and use of Jatropha biodiesel emits fewer life cycle GHG emissions than the production and use of petroleum diesel does not change.

The subsequent sections report important aspects of the model that define the base case scenario. 


\section{Base Case Scenario}

Aspects of the model that define the base case scenario are separated into six primary categories, as listed below. Details on the included data and processes are highlighted in each corresponding subsection of the report.

1. Petroleum diesel production and distribution (Reference System)

2. Jatropha cultivation

3. Jatropha oil extraction

4. Biodiesel production via Jatropha oil transesterification

5. Transport vehicle operation

6. Supporting processes.

Each category is defined in SimaPro by several modules, as shown in Figure 10-Figure 15. Many of the modules were developed by the authors. These are referred to hereafter as "custom" modules. The exact coding of the custom modules is reported in Appendix A. Where Indiaspecific data were not available, ecoinvent 2.0 modules were used. These modules are labeled as such in Figure 10-Figure 15. The detailed coding of these modules cannot be reported, as the information is proprietary.

\subsection{Petroleum Diesel Production and Distribution (Reference System)}

Both the conventional petroleum-diesel reference system and the biodiesel pathways include the life cycle impacts of diesel fuel production and distribution. Biodiesel pathways include diesel impacts associated with diesel fuel consumption in vehicles used for collecting seeds and distributing processed biodiesel. Figure 10 displays the modules used to model the petroleum diesel production and distribution system in SimaPro that applies both to diesel-fueled rail and road transport and to consumption of diesel fuel in transport vehicles during other life cycle stages. 


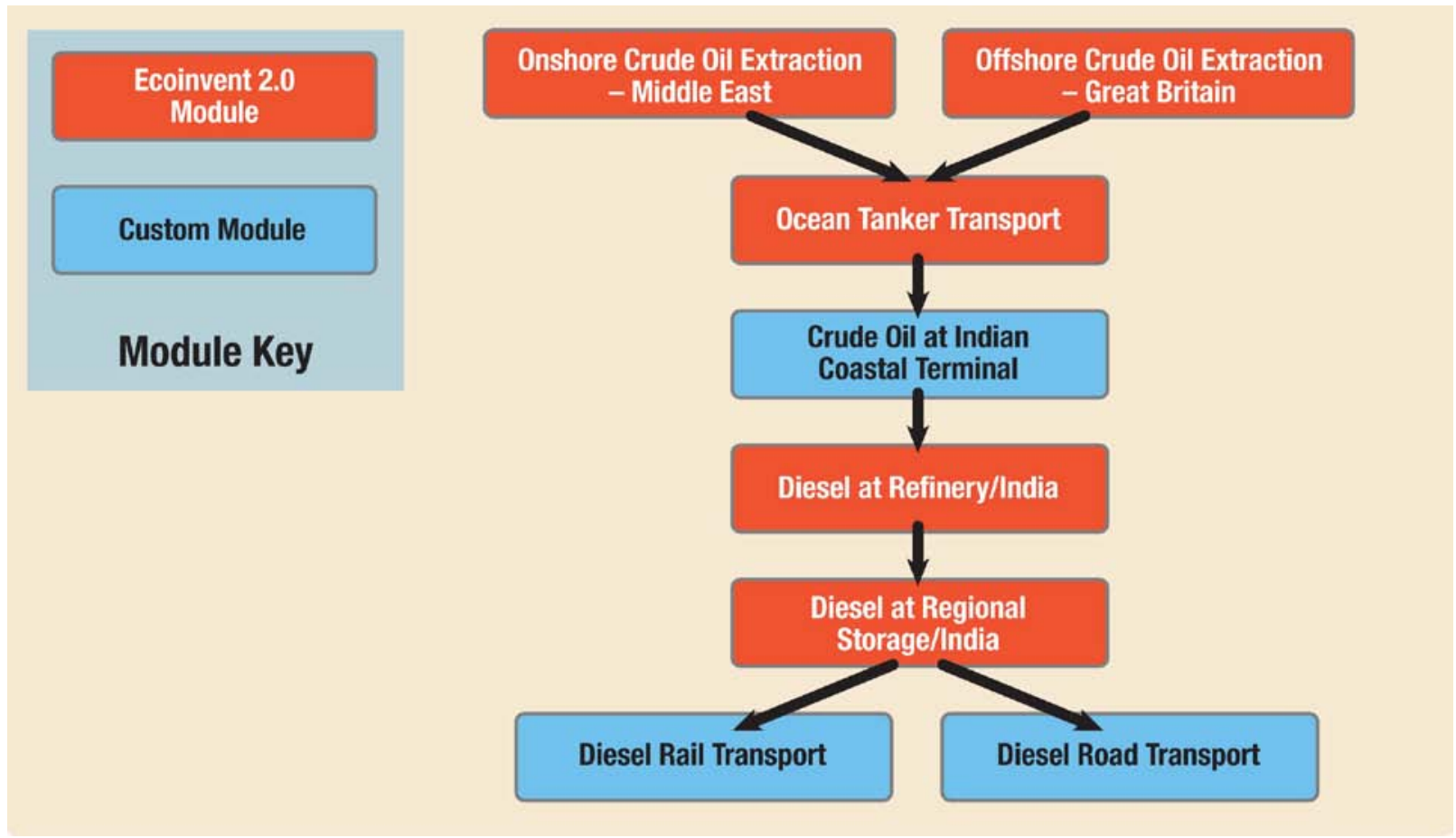

Figure 10. Modeling schematic for petroleum diesel production and distribution processes

Table 2 describes the purpose of each custom and ecoinvent 2.0 module utilized in modeling the petroleum diesel production and distribution processes. 
Table 2. SimaPro module descriptions for petroleum diesel production and distribution

\begin{tabular}{|c|c|c|}
\hline Module Name & Module Purpose & Comments \\
\hline $\begin{array}{l}\text { Onshore Crude } \\
\text { Oil Extraction- } \\
\text { Middle East }\end{array}$ & $\begin{array}{l}\text { This ecoinvent } 2.0 \text { module calculates } \\
\text { the impacts of onshore oil production in } \\
\text { the Middle East. As the largest fraction } \\
\text { of Indian foreign crude oil originates in } \\
\text { the Middle East, this module is used to } \\
\text { represent the } 70 \% \text { of Indian crude oil } \\
\text { that is from foreign sources. }\end{array}$ & $\begin{array}{l}\text { Indian oil may also come from foreign } \\
\text { offshore or onshore sources, Africa } \\
\text { (particularly Nigeria), or other foreign } \\
\text { locations. Oil from these sources is not } \\
\text { considered in this study. }\end{array}$ \\
\hline $\begin{array}{l}\text { Offshore Crude } \\
\text { Oil Extraction- } \\
\text { Great Britain }\end{array}$ & $\begin{array}{l}\text { This ecoinvent } 2.0 \text { module calculates } \\
\text { the impacts of offshore oil production } \\
\text { near Great Britain. The module is used } \\
\text { as a proxy for the impacts of domestic } \\
\text { offshore oil production from the Bombay } \\
\text { High oil fields in India. }\end{array}$ & $\begin{array}{l}\text { The largest share of domestically produced } \\
\text { Indian crude oil is produced offshore at the } \\
\text { Bombay High oil fields. The ecoinvent } \\
\text { module for offshore crude oil production in } \\
\text { Great Britain is used as a proxy for Indian } \\
\text { production. }\end{array}$ \\
\hline $\begin{array}{l}\text { Ocean Tanker } \\
\text { Transport }\end{array}$ & $\begin{array}{l}\text { This ecoinvent } 2.0 \text { module calculates } \\
\text { the impacts of the transport of foreign } \\
\text { and domestic crude oil via ocean tanker } \\
\text { to the coastal terminal of } \\
\text { Visakhapatnam in India. }\end{array}$ & $\begin{array}{l}\text { Crude oil is assumed to be delivered to the } \\
\text { port at Visakhapatnam, India, adjacent to } \\
\text { the VIZAG refinery. Foreign oil originates in } \\
\text { Saudi Arabia, domestic oil from Bombay } \\
\text { High. }\end{array}$ \\
\hline $\begin{array}{l}\text { Crude Oil at } \\
\text { Indian Refinery }\end{array}$ & $\begin{array}{l}\text { This custom module aggregates crude } \\
\text { oil produced domestically and from } \\
\text { foreign sources at the port at } \\
\text { Visakhapatnam, India prior to refining. }\end{array}$ & $\begin{array}{l}\text { The custom module in SimaPro } \\
\text { incorporates the impacts of production of } \\
\text { crude oil from the various sources and the } \\
\text { ocean transport to deliver crude oil to the } \\
\text { VIZAG refinery. }\end{array}$ \\
\hline $\begin{array}{l}\text { Diesel at } \\
\text { Refinery/India }\end{array}$ & $\begin{array}{l}\text { This modified ecoinvent } 2.0 \text { module } \\
\text { quantifies the impacts of refining crude } \\
\text { oil into high-speed diesel }{ }^{5} \text { This module } \\
\text { represents an average European } \\
\text { refinery from year } 2000 \text { customized to } \\
\text { VIZAG conditions. }\end{array}$ & $\begin{array}{l}\text { The parameters modified to India-specific } \\
\text { conditions in this module include the } \\
\text { source of crude oil, required electricity, and } \\
\text { thermal energy consumption. }\end{array}$ \\
\hline $\begin{array}{l}\text { Diesel at } \\
\text { Regional } \\
\text { Storage/India }\end{array}$ & $\begin{array}{l}\text { This modified ecoinvent } 2.0 \text { module } \\
\text { quantifies the impacts from distributing } \\
\text { diesel to regional storage via road, rail, } \\
\text { and pipeline. }\end{array}$ & $\begin{array}{l}\text { The ecoinvent diesel at regional storage } \\
\text { module accounts for losses that occur } \\
\text { during diesel distribution and refueling of } \\
\text { vehicles. The only modifications to India- } \\
\text { specific conditions are the refinery } \\
\text { supplying the diesel fuel (based on VIZAG) } \\
\text { and the freight-rail distance for transport to } \\
\text { assumed market of Bhilai. }\end{array}$ \\
\hline $\begin{array}{l}\text { Diesel Rail } \\
\text { Transport }\end{array}$ & $\begin{array}{l}\text { This custom module represents the end } \\
\text { use of diesel fuel for rail transport. }\end{array}$ & $\begin{array}{l}\text { This use of diesel fuel is modeled in two } \\
\text { sub-markets, passenger (narrow gauge) } \\
\text { and freight (heavy gauge), each with its } \\
\text { own specific fuel economy. }\end{array}$ \\
\hline $\begin{array}{l}\text { Diesel Road } \\
\text { Transport }\end{array}$ & $\begin{array}{l}\text { This custom module represents the end } \\
\text { use of diesel fuel for road transport. }\end{array}$ & $\begin{array}{l}\text { This use of diesel fuel is modeled in two } \\
\text { sub-markets, passenger (bus) and freight } \\
\text { (truck), each with its own specific fuel } \\
\text { economy (see Table 11). }\end{array}$ \\
\hline
\end{tabular}

Key data used to develop the custom module for Indian crude oil production and distribution are reported in Table 3. Seventy percent of Indian crude oil comes from foreign sources with the greatest percentage originating in the Middle East (Bureau of Energy Efficiency, India 2008).

\footnotetext{
${ }^{5}$ Indian refinery specifications refer to the production of high-speed diesel for use in motor vehicles. That terminology is maintained here for consistency with the reference.
} 
IOC indicated an average of $75 \%$ of its crude oil supply originates from foreign sources (Sarin 2008e). Domestically, the largest percentage of Indian oil is extracted from the offshore oil fields at Bombay High (Ministry of Petroleum and Natural Gas 2006). As tracing a specific drop of oil through the Indian system is not possible, this study constructs a plausible base case scenario based on country averages, where foreign oil is extracted from Saudi Arabia (U.S. Energy Information Administration 2007a) and domestic oil is extracted from Bombay High, with both locations shipping the crude oil via ocean tanker to the VIZAG refinery on the east coast of India. The refinery module is customized to reflect the specific electricity and thermal energy consumption of VIZAG (Hindustan Petroleum Corporation Limited 2008). Refined diesel is then shipped via rail to the fueling depot at Bhilai, near Raipur, for use in transport vehicles.

Table 3. Base case data inputs for petroleum diesel production and distribution*

\begin{tabular}{|c|c|c|c|c|}
\hline Parameter & Value & Units & Assumptions/Notes & Source \\
\hline $\begin{array}{l}\text { Foreign Crude } \\
\text { Oil }\end{array}$ & 0.75 & Mass fraction & $\begin{array}{l}\text { Fraction of India's crude oil from } \\
\text { foreign sources }\end{array}$ & Sarin $2008 e$ \\
\hline $\begin{array}{l}\text { Domestic Crude } \\
\text { Oil }\end{array}$ & 0.25 & Mass fraction & $\begin{array}{l}\text { Fraction of India's crude oil from } \\
\text { domestic sources }\end{array}$ & Sarin $2008 e$ \\
\hline $\begin{array}{l}\text { Foreign Crude } \\
\text { Oil Transport }\end{array}$ & 7,000 & $\mathrm{~km}$ & $\begin{array}{l}\text { Transport distance by ocean } \\
\text { tanker between Middle East and } \\
\text { VIZAG Refinery }\end{array}$ & Distances 2008 \\
\hline $\begin{array}{l}\text { Domestic Crude } \\
\text { Oil Transport }\end{array}$ & 3,200 & $\mathrm{~km}$ & $\begin{array}{l}\text { Transport distance by ocean } \\
\text { tanker between Bombay High } \\
\text { and VIZAG Refinery }\end{array}$ & Distances 2008 \\
\hline $\begin{array}{l}\text { Rail Distribution } \\
\text { of Diesel Fuel }\end{array}$ & 600 & $\mathrm{~km}$ & $\begin{array}{l}\text { Distance diesel fuel travels by } \\
\text { rail from VIZAG oil terminal to } \\
\text { Bhilai }\end{array}$ & $\begin{array}{l}\text { Distance Calculator } \\
\text { India } 2008\end{array}$ \\
\hline $\begin{array}{l}\text { Electricity } \\
\text { consumption }\end{array}$ & 31.91 & $\begin{array}{l}\mathrm{kWh} / \text { tonne } \\
\text { crude oil } \\
\text { processed }\end{array}$ & $\begin{array}{l}\text { Specific electricity consumption } \\
\text { for refinery operations at VIZAG }\end{array}$ & $\begin{array}{l}\text { Hindustan Petroleum } \\
\text { Corporation Limited } \\
2008\end{array}$ \\
\hline $\begin{array}{l}\text { Thermal energy } \\
\text { consumption }\end{array}$ & 1,550 & $\begin{array}{l}\text { MJ/tonne } \\
\text { crude oil } \\
\text { processed }\end{array}$ & $\begin{array}{l}\text { Specific thermal energy } \\
\text { consumption for refinery } \\
\text { operations at VIZAG }\end{array}$ & $\begin{array}{l}\text { Hindustan Petroleum } \\
\text { Corporation Limited } \\
2008\end{array}$ \\
\hline
\end{tabular}

* Characteristics of all transport modes are reported in Table 11. 


\subsection{Jatropha Cultivation}

Modeling the cultivation of Jatropha trees and the operation of the plantation requires data on numerous inputs including fertilizer use, irrigation water (for both plantation establishment and ongoing cultivation), electricity, and diesel fuel along with parameters such as the rate of $\mathrm{N}_{2} \mathrm{O}$ release from nitrogen fertilizer. This portion of the model carries the greatest uncertainty as deterministic correlations amongst cultivation parameters, including environmental conditions and human inputs, are not well established. Figure 11 outlines the processes included in the modeling of Jatropha cultivation.

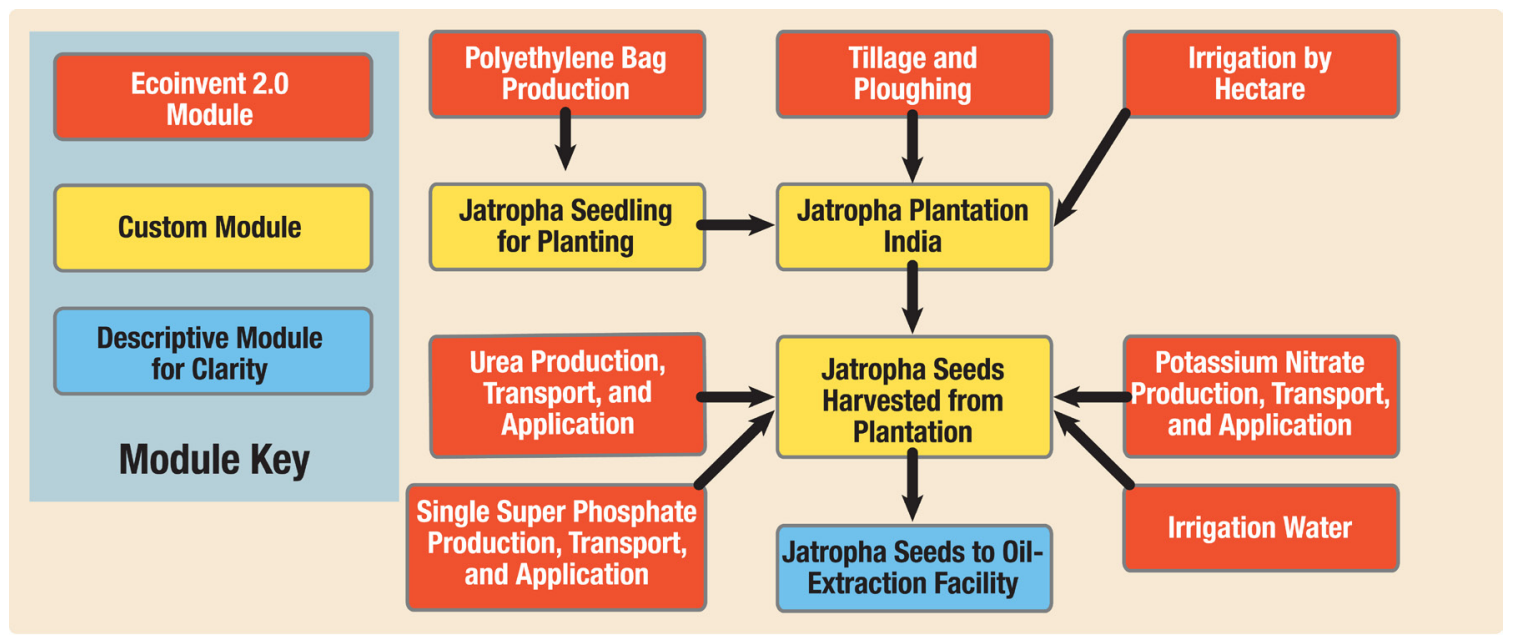

Figure 11. Modeling schematic for Jatropha cultivation processes

Table 4 describes the purpose of each module utilized in the analysis of Jatropha cultivation. Table 5 summarizes key base case input parameters for Jatropha cultivation.

The nitrous oxide release rate in Table 5 represents the default value of $0.01 \mathrm{~g} \mathrm{~N}_{2} \mathrm{O} / \mathrm{g} \mathrm{N}$ in fertilizer reported by IPCC (2006) from a stated range of $0.003-0.03 \mathrm{~g} \mathrm{~N}_{2} \mathrm{O} / \mathrm{g} \mathrm{N}$ in fertilizer. The emission factor accounts for direct emissions from a variety of organic and synthetic nitrogen fertilizers. It also accounts for crop residue and mineralization of organic carbon in the soil that are due to land management and land-use changes. The emission factor does not include secondary or indirect emission sources of $\mathrm{N}_{2} \mathrm{O}$ such as leached nitrogen $(\mathrm{N})$ entering water systems, crop residue being plowed into the fields for successor crops, or dung and urine being produced by animals that feed on the crops. Crutzen et al. (2008) use a top-down calculation method to suggest that the actual $\mathrm{N}_{2} \mathrm{O}-\mathrm{N}$ emission factor may be 3-5 times larger than the default IPCC value (ranging from $0.03-0.05 \mathrm{~g} \mathrm{~N}_{2} \mathrm{O} / \mathrm{g} \mathrm{N}$ in fertilizer). The impact of the uncertainty in this parameter on overall study results is tested in the sensitivity analysis.

The plantation electricity parameter is also uncertain, as Lele (2008b) does not explicitly state what plantation operations are included in this estimate. We consider Lele's estimate of plantation electricity use a likely upper bound as it may double count some of the electricity required for plantation processes such as irrigation and oil extraction that are modeled separately.

The module used to evaluate irrigation impacts is based on an ecoinvent 2.0 European irrigation module that may assume more energy consumption than would be present in an Indian irrigation system if either drip or manual irrigation were used. However, data describing the energy 
consumption by Indian irrigation systems was lacking in the literature. Parametric sensitivity analyses (see Section 7.2) indicated that the modeled energy use of the irrigation system has a negligible impact on results.

Table 4. SimaPro module descriptions for Jatropha cultivation

\begin{tabular}{|c|c|c|}
\hline Module Name & Module Purpose & Comments \\
\hline $\begin{array}{l}\text { Polyethylene Bag } \\
\text { Production }\end{array}$ & $\begin{array}{l}\text { This ecoinvent } 2.0 \text { module calculates the impacts } \\
\text { of producing and transporting the polyethylene } \\
\text { used in the Jatropha seedling bags at the } \\
\text { nursery. }\end{array}$ & $\begin{array}{l}\text { Each Jatropha seedling is } \\
\text { generally raised in a } \\
\text { polyethylene bag for the first } \\
\text { few months. }\end{array}$ \\
\hline $\begin{array}{l}\text { Tillage and } \\
\text { Ploughing }\end{array}$ & $\begin{array}{l}\text { This ecoinvent } 2.0 \text { module calculates the impacts } \\
\text { of the mechanized clearing and preparing of the } \\
\text { required land for developing the Jatropha } \\
\text { plantation. }\end{array}$ & $\begin{array}{l}\text { The base case assumes that } \\
50,000 \text { hectares are cleared for } \\
\text { plantation land based on IOC } \\
\text { guidance. }\end{array}$ \\
\hline $\begin{array}{l}\text { Irrigation by } \\
\text { Hectare }\end{array}$ & $\begin{array}{l}\text { This ecoinvent } 2.0 \text { module calculates the impacts } \\
\text { of irrigating the plantation area during initial } \\
\text { planting of the trees to aid establishment. }\end{array}$ & $\begin{array}{l}\text { Irrigation data are not well } \\
\text { established for Jatropha } \\
\text { plantations. The best available } \\
\text { data are used and tested in } \\
\text { sensitivity analyses. }\end{array}$ \\
\hline $\begin{array}{l}\text { Jatropha Seedling } \\
\text { for Planting }\end{array}$ & $\begin{array}{l}\text { This custom module is designed to represent the } \\
\text { requirements for the cultivation of Jatropha } \\
\text { seedlings at the nursery. The nursery is likely to } \\
\text { be located at or near the plantation. }\end{array}$ & $\begin{array}{l}\text { Information for this module is } \\
\text { incomplete as only the } \\
\text { polyethylene bag requirement } \\
\text { is known. Better data are } \\
\text { needed to identify energy } \\
\text { requirements of the nursery. } \\
\text { However, impacts are likely } \\
\text { very small. }\end{array}$ \\
\hline $\begin{array}{l}\text { Jatropha } \\
\text { Plantation, } \\
\text { Planted, India }\end{array}$ & $\begin{array}{l}\text { This custom module calls the required number of } \\
\text { seedlings, fertilizer, tillage and plowing, and } \\
\text { irrigation water to establish the Jatropha trees on } \\
\text { the plantation. The output is a hectare of planted } \\
\text { Jatropha plantation. }\end{array}$ & $\begin{array}{l}\text { The impacts for operating and } \\
\text { managing the plantation are } \\
\text { separately tracked in the } \\
\text { "Jatropha Seeds Harvested } \\
\text { from Plantation" module. }\end{array}$ \\
\hline $\begin{array}{l}\text { Jatropha Seeds } \\
\text { Harvested from } \\
\text { Plantation }\end{array}$ & $\begin{array}{l}\text { This custom module quantifies all of the impacts } \\
\text { associated with operating and managing the } \\
\text { plantation after the establishment period. } \\
\text { Plantation management impacts are normalized } \\
\text { per tonne of seeds produced. Jatropha fruit } \\
\text { harvesting and de-husking are assumed to be } \\
\text { done with manual labor. Combustion of Jatropha } \\
\text { husk and biomass from pruning is assumed to } \\
\text { offset delivered Indian electricity (i.e., including } \\
\text { Indian transmission and distribution losses). }\end{array}$ & $\begin{array}{l}\text { This module calls the required } \\
\text { inputs from the fertilizer and } \\
\text { irrigation modules along with } \\
\text { electricity and diesel fuel for } \\
\text { plantation operation and } \\
\text { contains much of the model's } \\
\text { uncertainty. }\end{array}$ \\
\hline $\begin{array}{l}\text { Urea Production, } \\
\text { Transport, \& } \\
\text { Application }\end{array}$ & $\begin{array}{l}\text { This ecoinvent } 2.0 \text { module quantifies the impacts } \\
\text { of producing, transporting, and applying urea to } \\
\text { provide the required amount of nitrogen to the } \\
\text { plantation. }\end{array}$ & $\begin{array}{l}\text { Required fertilizer levels are not } \\
\text { well defined for the } \\
\text { management of Jatropha } \\
\text { plantations. }\end{array}$ \\
\hline $\begin{array}{l}\text { Single Super } \\
\text { Phosphate } \\
\text { Production, } \\
\text { Transport, \& } \\
\text { Application }\end{array}$ & $\begin{array}{l}\text { This ecoinvent } 2.0 \text { module quantifies the impacts } \\
\text { of producing, transporting, and applying single } \\
\text { super phosphate to provide the required amount } \\
\text { of phosphate to the plantation. }\end{array}$ & $\begin{array}{l}\text { Required fertilizer levels are not } \\
\text { well defined for the } \\
\text { management of Jatropha } \\
\text { plantations. }\end{array}$ \\
\hline $\begin{array}{l}\text { Potassium } \\
\text { Chloride } \\
\text { Production, } \\
\text { Transport, \& }\end{array}$ & $\begin{array}{l}\text { This ecoinvent } 2.0 \text { module quantifies the impacts } \\
\text { of producing, transporting, and applying } \\
\text { potassium chloride to provide the required } \\
\text { amount of potassium. }\end{array}$ & $\begin{array}{l}\text { Required fertilizer levels are not } \\
\text { well defined for the } \\
\text { management of Jatropha } \\
\text { plantations. }\end{array}$ \\
\hline
\end{tabular}




\begin{tabular}{|c|c|c|}
\hline Module Name & Module Purpose & Comments \\
\hline Application & & \\
\hline $\begin{array}{l}\text { Irrigation by } \\
\text { Hectare }\end{array}$ & $\begin{array}{l}\text { This ecoinvent } 2.0 \text { modules account for the } \\
\text { impacts of irrigating one hectare of land during } \\
\text { plantation establishment. }\end{array}$ & $\begin{array}{l}\text { Irrigation required for plantation } \\
\text { establishment is estimated } \\
\text { based on European averages, } \\
\text { as Indian-specific data for } \\
\text { Jatropha cultivation was } \\
\text { unavailable. }\end{array}$ \\
\hline $\begin{array}{l}\text { Irrigation Water } \\
\text { Required }\end{array}$ & $\begin{array}{l}\text { This ecoinvent } 2.0 \text { module accounts for the } \\
\text { impacts of applying the required levels of } \\
\text { irrigation water to the plantation for ongoing } \\
\text { Jatropha cultivation and maintenance. }\end{array}$ & $\begin{array}{l}\text { The required amount of water is } \\
\text { calculated based on the } \\
\text { anticipated water requirement } \\
\text { per week of the growing season } \\
\text { and the fraction of required } \\
\text { water assumed to be met by } \\
\text { rainfall. }\end{array}$ \\
\hline
\end{tabular}

Table 5. Base case data inputs for Jatropha cultivation

Base case assumes no application of pesticides, herbicides, or insecticides.

\begin{tabular}{|c|c|c|c|c|}
\hline Parameter & Value & Units & Assumptions/Notes & Source \\
\hline Life cycle & 20 & years & $\begin{array}{l}\text { Defines the lifetime over } \\
\text { which all inputs and outputs } \\
\text { are tracked }\end{array}$ & $\begin{array}{l}\text { Reinhardt et al. } \\
2007\end{array}$ \\
\hline $\begin{array}{l}\text { Plantation } \\
\text { Location }\end{array}$ & $\begin{array}{l}\text { Raipur } \\
\text { area }\end{array}$ & $\begin{array}{l}\text { Chhattisgarh } \\
\text { India }\end{array}$ & $\begin{array}{l}\text { Target plantation location } \\
\text { selected by IOC }\end{array}$ & Sarin $2008 b$ \\
\hline $\begin{array}{l}\text { Plantation } \\
\text { Rainfall }\end{array}$ & 1,385 & $\mathrm{~mm} / \mathrm{yr}$ & Average rainfall for Raipur & $\begin{array}{l}\text { Chhattisgarh } \\
\text { Online } 2008\end{array}$ \\
\hline Plantation Size & 50,000 & Hectares & $\begin{array}{l}\text { Based on IOC anticipated } \\
\text { plantation size }\end{array}$ & Sarin 2008b \\
\hline $\begin{array}{l}\text { Seedling } \\
\text { Survival Rate }\end{array}$ & 0.8 & $\begin{array}{l}\text { Surviving } \\
\text { seedlings/total } \\
\text { seedling planted }\end{array}$ & $\begin{array}{l}\text { Represents Jatropha seedling } \\
\text { survival rate of } 80 \% \text { under } \\
\text { average planting conditions }\end{array}$ & $\begin{array}{l}\text { Lele 2008a; } \\
\text { Renewable } \\
\text { Energy U.K. } \\
\text { site } 2008\end{array}$ \\
\hline Tree Density & 2,500 & Trees/hectare & $\begin{array}{l}\text { Assumed initial Jatropha tree } \\
\text { density based on Planning } \\
\text { Commission assumptions }\end{array}$ & $\begin{array}{l}\text { Planning } \\
\text { Commission } \\
2003\end{array}$ \\
\hline $\begin{array}{l}\text { Years Required } \\
\text { for Irrigation }\end{array}$ & 3 & Years & $\begin{array}{l}\text { Reinhardt et al.'s optimized } \\
\text { scenario assumes irrigation is } \\
\text { only required for the first three } \\
\text { years of plantation } \\
\text { establishment }\end{array}$ & $\begin{array}{l}\text { Reinhardt et al. } \\
2008\end{array}$ \\
\hline $\begin{array}{l}\text { Jatropha Water } \\
\text { Requirement }\end{array}$ & 6 & $\begin{array}{l}\text { Liters per tree per } \\
\text { week }\end{array}$ & $\begin{array}{l}\text { Total water required per } \\
\text { Jatropha tree from rainfall and } \\
\text { irrigation during the growing } \\
\text { season based on potential } \\
\text { evapotranspiration }\end{array}$ & $\begin{array}{l}\text { Kheira and Atta } \\
2008\end{array}$ \\
\hline $\begin{array}{l}\text { Growing } \\
\text { Season Weeks }\end{array}$ & 30 & Weeks/year & $\begin{array}{l}\text { Length of the annual Jatropha } \\
\text { growing season including } \\
\text { initial development, flowering, } \\
\text { and harvesting }\end{array}$ & $\begin{array}{l}\text { Kheira and Atta } \\
2008\end{array}$ \\
\hline $\begin{array}{l}\text { Water } \\
\text { Requirement } \\
\text { Met }\end{array}$ & 100 & $\%$ & $\begin{array}{l}\text { Percent of the Jatropha water } \\
\text { requirement met through the } \\
\text { combination of rain and }\end{array}$ & $\begin{array}{l}\text { Base case } \\
\text { assumption }\end{array}$ \\
\hline
\end{tabular}




\begin{tabular}{|c|c|c|c|c|}
\hline Parameter & Value & Units & Assumptions/Notes & Source \\
\hline & & & irrigation water & \\
\hline $\begin{array}{l}\text { Fraction Met } \\
\text { with Irrigation }\end{array}$ & 0.2 & Mass fraction & $\begin{array}{l}\text { Fraction of Jatropha water } \\
\text { requirement met with irrigation } \\
\text { water during years in which } \\
\text { irrigation is used in order to } \\
\text { ensure adequate water is } \\
\text { delivered at the required times }\end{array}$ & $\begin{array}{l}\text { Base case } \\
\text { assumption }\end{array}$ \\
\hline $\begin{array}{l}\text { Fertilizer } \\
\text { Application }\end{array}$ & 2 & Applications/year & $\begin{array}{l}\text { Assumes one fertilizer } \\
\text { application each at the } \\
\text { beginning and end of the rainy } \\
\text { season }\end{array}$ & Lele 2008a \\
\hline $\begin{array}{l}\text { Urea Fertilizer } \\
\text { Required }\end{array}$ & 81 & kg/ha-yr & $\begin{array}{l}\text { Urea fertilizer use based on } \\
\text { the Optimized scenario of } \\
\text { Reinhardt et al. Reinhardt } \\
\text { assumed a density of } 1,667 \\
\text { trees/hectare, which is scaled } \\
\text { to the base case density }\end{array}$ & $\begin{array}{l}\text { Reinhardt et al. } \\
2008\end{array}$ \\
\hline $\begin{array}{l}\mathrm{P}_{2} \mathrm{O}_{5} \text { Fertilizer } \\
\text { Required }\end{array}$ & 31 & kg/ha-yr & $\begin{array}{l}\mathrm{P}_{2} \mathrm{O}_{5} \text { fertilizer use based on } \\
\text { the Optimized scenario of } \\
\text { Reinhardt et al. }\end{array}$ & $\begin{array}{l}\text { Reinhardt et al. } \\
2008\end{array}$ \\
\hline $\begin{array}{l}\mathrm{K}_{2} \mathrm{O} \text { Fertilizer } \\
\text { Required }\end{array}$ & 89 & kg/ha-yr & $\begin{array}{l}\mathrm{K}_{2} \mathrm{O} \text { fertilizer use based on } \\
\text { the Optimized scenario of } \\
\text { Reinhardt et al. }\end{array}$ & $\begin{array}{l}\text { Reinhardt et al. } \\
2008\end{array}$ \\
\hline $\begin{array}{l}\text { Diesel Fuel } \\
\text { Required }\end{array}$ & 86 & liters/ha-yr & $\begin{array}{l}\text { Diesel fuel use based on the } \\
\text { Optimized scenario of } \\
\text { Reinhardt et al. }\end{array}$ & $\begin{array}{l}\text { Reinhardt et al. } \\
2008\end{array}$ \\
\hline $\begin{array}{l}\text { Nitrous Oxide } \\
\text { Release }\end{array}$ & 0.01 & $\begin{array}{l}\mathrm{g} \mathrm{N}_{2} \mathrm{O} / \mathrm{g} \mathrm{N} \text { in } \\
\text { fertilizer }\end{array}$ & $\begin{array}{l}\text { Fraction of nitrogen contained } \\
\text { in fertilizer that is released to } \\
\text { the air based on IPCC's } \\
\text { default value for } \mathrm{N}_{2} \mathrm{O} \\
\text { emissions from nitrogen } \\
\text { fertilizers }\end{array}$ & IPCC 2006 \\
\hline $\begin{array}{l}\text { Oil Content of } \\
\text { Jatropha Seed }\end{array}$ & 0.35 & $\begin{array}{l}\text { Mass oil/mass total } \\
\text { seed }\end{array}$ & $\begin{array}{l}\text { Assumed average oil content } \\
\text { of dry seed on mass basis; } \\
\text { matches assumption of the } \\
\text { Indian Planning Commission }\end{array}$ & $\begin{array}{l}\text { Achten et al. } \\
2008\end{array}$ \\
\hline $\begin{array}{l}\text { Plantation } \\
\text { Electricity }\end{array}$ & 12,000 & $\mathrm{MWh} / \mathrm{yr}$ & $\begin{array}{l}\text { Approximate electricity } \\
\text { required to operate a } 50,000 \\
\text { hectare plantation for one } \\
\text { year }\end{array}$ & Lele 2008b \\
\hline $\begin{array}{l}\text { Seed Husk } \\
\text { Yield }\end{array}$ & 1,429 & $\begin{array}{l}\text { kg sun dried } \\
\text { husks/ha-yr }\end{array}$ & $\begin{array}{l}\text { Estimated seed husk yield } \\
\text { after seed extraction and } \\
\text { assuming water content of } \\
9 \% . \text { Based on the Optimized } \\
\text { scenario of Reinhardt et al. }\end{array}$ & $\begin{array}{l}\text { Reinhardt et al. } \\
2008\end{array}$ \\
\hline $\begin{array}{l}\text { Seed Husk } \\
\text { Energy Density }\end{array}$ & 15.5 & $\mathrm{MJ} / \mathrm{kg}$ & $\begin{array}{l}\text { Gross energy content of the } \\
\text { dry matter of Jatropha seed } \\
\text { husks }\end{array}$ & $\begin{array}{l}\text { Reinhardt et al. } \\
2008\end{array}$ \\
\hline $\begin{array}{l}\text { Jatropha Seed } \\
\text { Yield }\end{array}$ & 1.5 & $\begin{array}{l}\mathrm{kg} \text { sun dried } \\
\text { seeds/tree-yr }\end{array}$ & $\begin{array}{l}\text { Estimated Jatropha seed yield } \\
\text { per tree based on Planning } \\
\text { Commission assumptions }\end{array}$ & $\begin{array}{l}\text { Planning } \\
\text { Commission } \\
2003\end{array}$ \\
\hline $\begin{array}{l}\text { Biomass Yield, } \\
\text { Year } 1\end{array}$ & 2.5 & $\mathrm{~kg}$ biomass/tree & $\begin{array}{l}\text { IOC supplied estimate of first } \\
\text { year biomass yield from } \\
\text { pruning }\end{array}$ & Sarin $2008 c$ \\
\hline
\end{tabular}




\begin{tabular}{|c|c|c|c|c|}
\hline Parameter & Value & Units & Assumptions/Notes & Source \\
\hline $\begin{array}{l}\text { Biomass Yield } \\
\text { Year } 2\end{array}$ & 4.5 & $\mathrm{~kg}$ biomass/tree & $\begin{array}{l}\text { IOC supplied estimate of } \\
\text { second year biomass yield } \\
\text { from pruning }\end{array}$ & Sarin $2008 c$ \\
\hline $\begin{array}{l}\text { Biomass Yield } \\
\text { from Mature } \\
\text { Jatropha Plants }\end{array}$ & 8.5 & $\mathrm{~kg}$ biomass/tree & $\begin{array}{l}\text { IOC supplied estimate of } \\
\text { biomass yield from pruning } \\
\text { mature Jatropha trees }\end{array}$ & Sarin $2008 c$ \\
\hline $\begin{array}{l}\text { Mass Fraction } \\
\text { Stems }\end{array}$ & 0.67 & Mass fraction & $\begin{array}{l}\text { Based on approximate } \\
\text { breakdown of dried Jatropha } \\
\text { plant biomass; remaining } \\
\text { mass fraction is comprised of } \\
\text { leaves }\end{array}$ & $\begin{array}{l}\text { Nivitchanyong } \\
2007\end{array}$ \\
\hline $\begin{array}{l}\text { Energy Density } \\
\text { of Leaves }\end{array}$ & 3.6 & $\mathrm{MJ} / \mathrm{kg}$ & $\begin{array}{l}\text { Gross specific energy content } \\
\text { of Jatropha leaves }\end{array}$ & $\begin{array}{l}\text { Nivitchanyong } \\
2007\end{array}$ \\
\hline $\begin{array}{l}\text { Energy Density } \\
\text { of Stems }\end{array}$ & 3.9 & $\mathrm{MJ} / \mathrm{kg}$ & $\begin{array}{l}\text { Gross specific energy content } \\
\text { of Jatropha stems }\end{array}$ & $\begin{array}{l}\text { Nivitchanyong } \\
2007\end{array}$ \\
\hline $\begin{array}{l}\text { Seed } \\
\text { Transportation }\end{array}$ & 50 & $\mathrm{~km}$ & $\begin{array}{l}\text { Assumed distance for } \\
\text { Jatropha seeds to be } \\
\text { transported by truck from } \\
\text { plantation to oil extraction unit }\end{array}$ & $\begin{array}{l}\text { Base Case } \\
\text { Assumption }\end{array}$ \\
\hline
\end{tabular}

\subsection{Jatropha Oil Extraction}

The process of extracting the oil from Jatropha seeds that is considered in this study is a continuous solvent process. While limited data describing this process have been published, the data used to model the base case are India-specific. An extraction efficiency of $91 \%$ is assumed (Planning Commission 2003). Figure 12 highlights the processes used to model Jatropha oil extraction while Table 6 describes the modules.
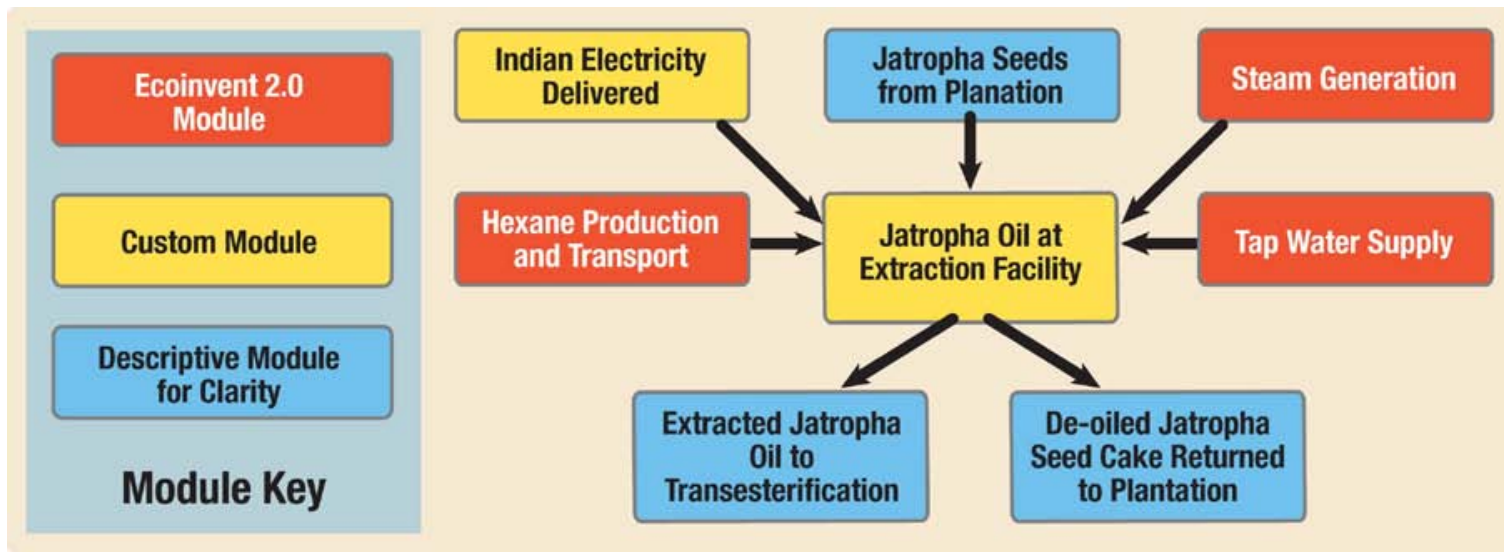

Figure 12. Modeling schematic for Jatropha oil extraction processes 
Table 6. SimaPro module descriptions for Jatropha oil extraction

\begin{tabular}{|c|c|c|}
\hline Module Name & Module Purpose & Comments \\
\hline $\begin{array}{l}\text { Indian Electricity } \\
\text { Delivered }\end{array}$ & $\begin{array}{l}\text { This custom module represents the Indian electric grid } \\
\text { mix supplied to the oil extraction unit. }\end{array}$ & $\begin{array}{l}\text { See Section } 0 \text { for more } \\
\text { details on the Indian } \\
\text { Electricity module. }\end{array}$ \\
\hline $\begin{array}{l}\text { Jatropha Oil at } \\
\text { Solvent Extraction } \\
\text { Facility, India }\end{array}$ & $\begin{array}{l}\text { This custom module calculates the impacts of } \\
\text { continuous solvent-based Jatropha oil extraction. } \\
\text { Amortized infrastructure of an oil extraction facility in } \\
\text { Western Europe is included. The process produces } \\
\text { Jatropha oil that is transported to the } \\
\text { transesterification plant, and de-oiled seed cake that is } \\
\text { returned to the plantation as a fertilizer. }\end{array}$ & $\begin{array}{l}\text { This module calls the } \\
\text { required inputs for } \\
\text { electricity, steam, hexane, } \\
\text { and water needed to } \\
\text { operate continuously. }\end{array}$ \\
\hline Steam Generation & $\begin{array}{l}\text { This ecoinvent } 2.0 \text { module calculates the impacts of } \\
\text { generating and delivering the steam required for the oil } \\
\text { extraction process. }\end{array}$ & $\begin{array}{l}\text { Generic steam production } \\
\text { is used because of a lack } \\
\text { of information on India- } \\
\text { specific processes for } \\
\text { generating steam for oil } \\
\text { extraction. }\end{array}$ \\
\hline $\begin{array}{l}\text { Hexane } \\
\text { Production and } \\
\text { Transport }\end{array}$ & $\begin{array}{l}\text { This ecoinvent } 2.0 \text { module quantifies the impacts of } \\
\text { producing and transporting the hexane that is used as } \\
\text { the solvent in the Jatropha oil extraction process. }\end{array}$ & $\begin{array}{l}\text { Hexane is the only solvent } \\
\text { used on a commercial } \\
\text { scale for oil extraction at } \\
\text { this time. }\end{array}$ \\
\hline Tap Water Supply & $\begin{array}{l}\text { This ecoinvent } 2.0 \text { module quantifies the impacts of } \\
\text { supplying tap water to the oil extraction facility for use } \\
\text { in the oil extraction process. }\end{array}$ & $\begin{array}{l}\text { The module is based on } \\
\text { Western European data as } \\
\text { India-specific water } \\
\text { production and delivery } \\
\text { data are unavailable. }\end{array}$ \\
\hline
\end{tabular}

Table 7 reports key base case data inputs used to model Jatropha oil extraction via a continuous solvent extraction process.

Table 7. Base case data inputs for Jatropha oil extraction

\begin{tabular}{|c|c|c|c|c|}
\hline Parameter & Value & Units & Assumptions/Notes & Source \\
\hline $\begin{array}{l}\text { Extraction } \\
\text { Efficiency }\end{array}$ & $91 \%$ & Mass percent & $\begin{array}{l}\text { Percent of Jatropha oil available in seeds } \\
\text { extracted via solvent extraction }\end{array}$ & $\begin{array}{l}\text { Planning } \\
\text { Commission } \\
2003\end{array}$ \\
\hline Electricity Use & 55 & $\begin{array}{l}\mathrm{kWh} / \text { tonne of } \\
\text { seed input }\end{array}$ & $\begin{array}{l}\text { Average electricity use for continuous } \\
\text { solvent extraction per metric ton (tonne) } \\
\text { of Jatropha seed input }\end{array}$ & Adriaans 2006 \\
\hline Hexane Use & 4 & $\begin{array}{l}\mathrm{kg} / \text { tonne of } \\
\text { seed input }\end{array}$ & $\begin{array}{l}\text { Average amount of hexane used in } \\
\text { continuous solvent extraction ( } 99 \% \text { is } \\
\text { recycled) }\end{array}$ & $\begin{array}{l}\text { Adriaans 2006; } \\
\text { Sarin 2008c }\end{array}$ \\
\hline Steam Use & 280 & $\begin{array}{l}\mathrm{kg} / \text { tonne of } \\
\text { seed input }\end{array}$ & $\begin{array}{l}\text { Average amount of steam suitable for } \\
\text { chemical processes required for } \\
\text { continuous solvent extraction }\end{array}$ & Adriaans 2006 \\
\hline Water Use & 12 & $\begin{array}{l}\mathrm{m}^{3} / \text { tonne of } \\
\text { seed input }\end{array}$ & $\begin{array}{l}\text { Average amount of water required for } \\
\text { continuous solvent extraction (consumed } \\
\text { and discharged to sewer) }\end{array}$ & Adriaans 2006 \\
\hline $\begin{array}{l}\text { Jatropha Oil } \\
\text { Transportation }\end{array}$ & 0 & $\mathrm{Km}$ & $\begin{array}{l}\text { Assumes oil extraction facility is co- } \\
\text { located with the transesterification plant }\end{array}$ & Sarin $2008 c$ \\
\hline
\end{tabular}




\subsection{Biodiesel Production via Jatropha Oil Transesterification}

The study focuses on base-catalyzed transesterification of Jatropha oil to biodiesel because this is the process that is promoted by the Planning Commission (2003). The modeled transesterification facility has a production capacity of 100,000 metric tonnes per annum (MTPA) to match the assumed facility size in the Planning Commission report. A 2008Indian Oil Research and Development Centre survey of biodiesel production facilities in India conducted for the Indian Ministry of Renewable Energy identified 14 facilities with capacities of at least 10,000 MTPA with 5 facilities having capacities of at least 100,000 MTPA (Puri 2009), so the assumption of 100,000 MTPA used in this research is warranted. Figure 13 outlines the important processes included in the model while Table 8 describes each module and Table 9 outlines the key parameters. The glycerol generated by the transesterification process is further refined to glycerine to make the quality suitable for the Indian market. The electricity and steam consumption values in Table 9 represent the energy consumed for both biodiesel transesterification and glycerol purification to glycerine.

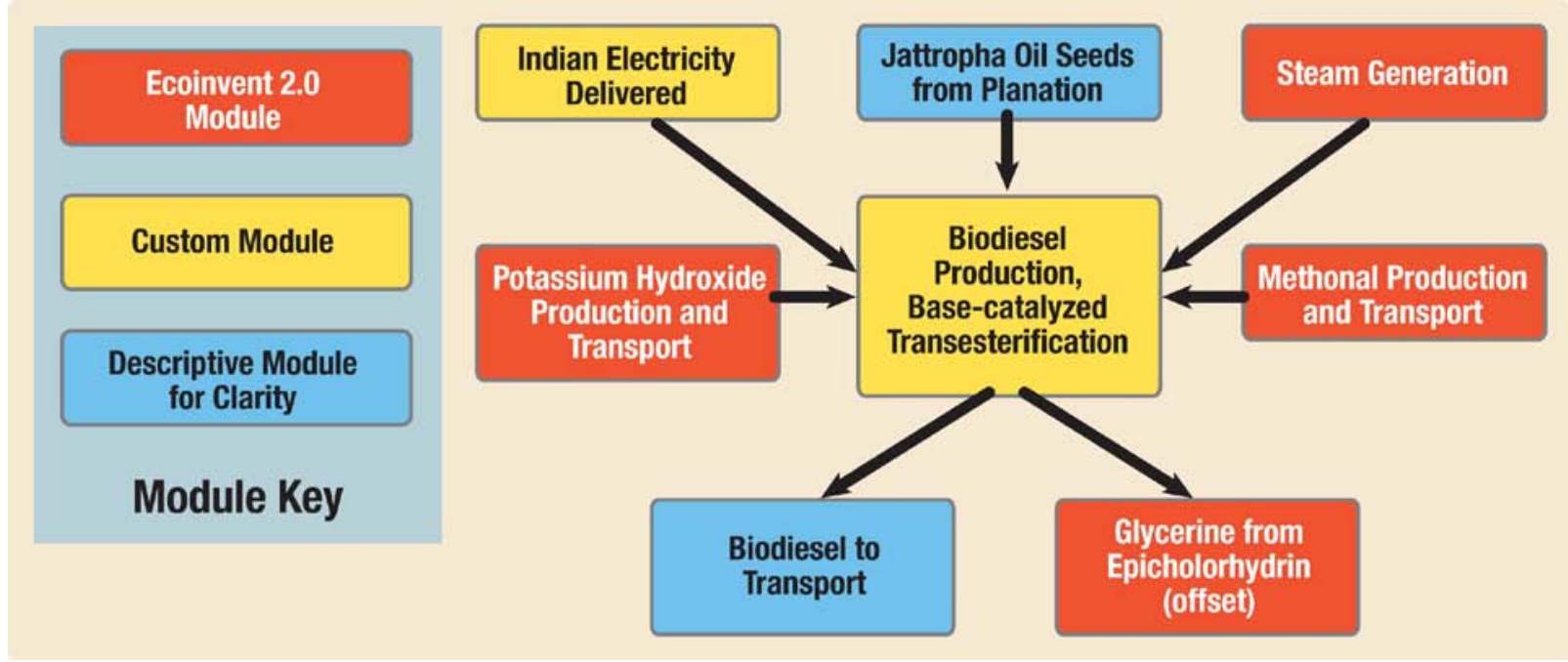

Figure 13. Modeling schematic for biodiesel production via Jatropha oil transesterification processes 
Table 8. SimaPro module descriptions for biodiesel production via Jatropha oil transesterification

\begin{tabular}{|c|c|c|}
\hline Module Name & Module Purpose & Comments \\
\hline $\begin{array}{l}\text { Indian Electricity } \\
\text { Delivered }\end{array}$ & $\begin{array}{l}\text { This custom module represents the Indian } \\
\text { electric grid mix supplied to the biodiesel } \\
\text { production unit. }\end{array}$ & $\begin{array}{l}\text { See Section } 0 \text { for more details on } \\
\text { the Indian Electricity module. }\end{array}$ \\
\hline $\begin{array}{l}\text { Biodiesel Production, } \\
\text { Base-catalyzed } \\
\text { Transesterification, } \\
\text { India }\end{array}$ & $\begin{array}{l}\text { This custom module calculates the } \\
\text { impacts of biodiesel production via base- } \\
\text { catalyzed Jatropha oil transesterification. } \\
\text { Infrastructure of a transesterification } \\
\text { facility in Western Europe is amortized. } \\
\text { The process produces biodiesel to be } \\
\text { transported to end users and glycerol to } \\
\text { offset synthetic glycerine production. }\end{array}$ & $\begin{array}{l}\text { This module calls the required } \\
\text { inputs of electricity, steam, } \\
\text { potassium hydroxide, methanol, } \\
\text { and water needed to operate. } \\
\text { Approximately } 50 \% \text { of supplied } \\
\text { methanol is recovered and recycled } \\
\text { for re-use in the process (SRS } \\
\text { Engineering 2009). }\end{array}$ \\
\hline Steam Generation & $\begin{array}{l}\text { This ecoinvent } 2.0 \text { module calculates the } \\
\text { impacts of generating and delivering the } \\
\text { steam required for the transesterification } \\
\text { process. }\end{array}$ & $\begin{array}{l}\text { Production of steam suitable for } \\
\text { chemical processes is used } \\
\text { because of a lack of information on } \\
\text { India-specific processes for } \\
\text { generating steam for } \\
\text { transesterification }\end{array}$ \\
\hline $\begin{array}{l}\text { Potassium Hydroxide } \\
\text { Production and } \\
\text { Transport }\end{array}$ & $\begin{array}{l}\text { This ecoinvent } 2.0 \text { module quantifies the } \\
\text { impacts of producing and transporting the } \\
\text { potassium hydroxide that is the base } \\
\text { catalyst for the transesterification process. }\end{array}$ & $\begin{array}{l}\text { Potassium hydroxide production is } \\
\text { modeled based on Western } \\
\text { European conditions because of a } \\
\text { lack of data on Indian production. }\end{array}$ \\
\hline $\begin{array}{l}\text { Methanol Production } \\
\text { and Transport }\end{array}$ & $\begin{array}{l}\text { This ecoinvent } 2.0 \text { module quantifies the } \\
\text { impacts of producing and transporting the } \\
\text { methanol that is used as the alcohol for } \\
\text { the transesterification process. }\end{array}$ & $\begin{array}{l}\text { Methanol production is modeled } \\
\text { based on Western European } \\
\text { conditions because of a lack of } \\
\text { data on Indian production. Source } \\
\text { of methanol is natural gas. }\end{array}$ \\
\hline $\begin{array}{l}\text { Glycerine from } \\
\text { Epicholorhydrin }\end{array}$ & $\begin{array}{l}\text { This } 2.0 \text { module quantifies the impacts } \\
\text { that are offset through the generation of } \\
\text { the co-product glycerol replacing some } \\
\text { synthetic glycerine production. }\end{array}$ & $\begin{array}{l}\text { The module is based on Western } \\
\text { European conditions because of a } \\
\text { lack of Indian data. }\end{array}$ \\
\hline
\end{tabular}


Table 9. Base case data inputs for biodiesel transesterification via Jatropha oil transesterification

\begin{tabular}{|c|c|c|c|c|}
\hline Parameter & Value & Units & Assumptions/Notes & Source \\
\hline $\begin{array}{l}\text { Conversion } \\
\text { Efficiency }\end{array}$ & $95 \%$ & Mass percent & $\begin{array}{l}\text { Conversion efficiency of Jatropha } \\
\text { oil to biodiesel }\end{array}$ & Lele $2008 \mathrm{c}$ \\
\hline Electricity Use & 38 & $\begin{array}{l}\mathrm{kWh} / \text { tonne of } \\
\text { biodiesel } \\
\text { produced }\end{array}$ & $\begin{array}{l}\text { Electricity use based on a } 100,000 \\
\text { tonne biodiesel/year plant }\end{array}$ & $\begin{array}{l}\text { Planning Commission } \\
\text { 2003; Lele 2008d }\end{array}$ \\
\hline Steam Use & 851 & $\begin{array}{l}\mathrm{kg} / \text { tonne of } \\
\text { biodiesel } \\
\text { produced }\end{array}$ & $\begin{array}{l}\text { Steam use based on a } 100,000 \\
\text { tonne biodiesel/year plant }\end{array}$ & $\begin{array}{l}\text { Planning Commission } \\
\text { 2003; Lele 2008d }\end{array}$ \\
\hline Water Use & 55 & $\mathrm{~m}^{3}$ circulated & $\begin{array}{l}\text { Water is circulated, not consumed, } \\
\text { so the amount reported here is for } \\
\text { initial loading of the system. }\end{array}$ & $\begin{array}{l}\text { Planning Commission } \\
2003\end{array}$ \\
\hline $\begin{array}{l}\text { Base Catalyst } \\
\text { Required }(\mathrm{KOH})\end{array}$ & 18 & $\begin{array}{l}\mathrm{kg} / \text { tonne of } \\
\text { biodiesel } \\
\text { produced }\end{array}$ & $\begin{array}{l}\mathrm{KOH} \text { used as base catalyst for a } \\
100,000 \text { tonne biodiesel/year plant }\end{array}$ & $\begin{array}{l}\text { Planning Commission } \\
2003\end{array}$ \\
\hline $\begin{array}{l}\text { Methanol } \\
\text { Required }\end{array}$ & 110 & $\begin{array}{l}\mathrm{kg} / \text { tonne of } \\
\text { biodiesel } \\
\text { produced }\end{array}$ & $\begin{array}{l}\text { Methanol use based on a } 100,000 \\
\text { tonne biodiesel/year plant; amount } \\
\text { of methanol consumed, data on } \\
\text { methanol recycling incorporated }\end{array}$ & $\begin{array}{l}\text { Planning Commission } \\
\text { (2003) }\end{array}$ \\
\hline $\begin{array}{l}\text { Mineral Acid } \\
\text { Required }\end{array}$ & 6 & $\begin{array}{l}\mathrm{kg} / \text { tonne of } \\
\text { biodiesel } \\
\text { produced }\end{array}$ & $\begin{array}{l}\text { Sulfuric acid used to represent the } \\
\text { required mineral acid }\end{array}$ & $\begin{array}{l}\text { Planning Commission } \\
\text { (2003) }\end{array}$ \\
\hline Glycerine Yield & 0.08 & Mass fraction & $\begin{array}{l}\text { Mass fraction yield of glycerine as } \\
\text { co-product during production of } \\
\text { biodiesel }\end{array}$ & Lele (2008d) \\
\hline $\begin{array}{l}\text { Biodiesel } \\
\text { Transportation }\end{array}$ & 20 & $\mathrm{~km}$ & $\begin{array}{l}\text { Distance between the } \\
\text { transesterification facility at Raipur } \\
\text { and the Bhilai fuel depots }\end{array}$ & $\begin{array}{l}\text { Distance Calculator } \\
\text { India (2008) }\end{array}$ \\
\hline
\end{tabular}

\subsection{Vehicle Operation}

Both the reference-petroleum diesel life cycle and the comparison-blended biodiesel scenarios end with the fuels being combusted to operate transport vehicles in India. Road transit is examined for both freight transport in long-distance trucks and passenger transport in buses. Rail transit is analyzed for both IR freight and passenger trains. This module also includes blending the fuels, distributing blended fuels to fueling stations, and fueling transport vehicles. Figure 14 displays the primary SimaPro modules for analyzing the vehicle operation, while Table 10 describes each process and Table 11outlines the key parameters.

Note that fuel consumption per GTK data for the Indian road freight transport sector was not available in the literature. As a result, European trucking data was used as a proxy. It is possible that the use of European trucking data will underestimate specific fuel consumption for Indian road freight transport. However, Whitaker (2007) discussed that Indian buses consume less fuel than U.S. buses, due in part to fewer auxiliary systems and lighter vehicle weights, so the direction of the bias of the proxy data is not clear on a per GTK basis. The use of this proxy data will only affect the relative GHG emissions and petroleum consumption between transport modes (e.g., road freight vs. road passenger) while not affecting the percentage changes in GHG emissions or petroleum consumption for biodiesel blends compared with conventional petroleum diesel for a selected transport mode (e.g., road freight B20 vs. road freight diesel). 


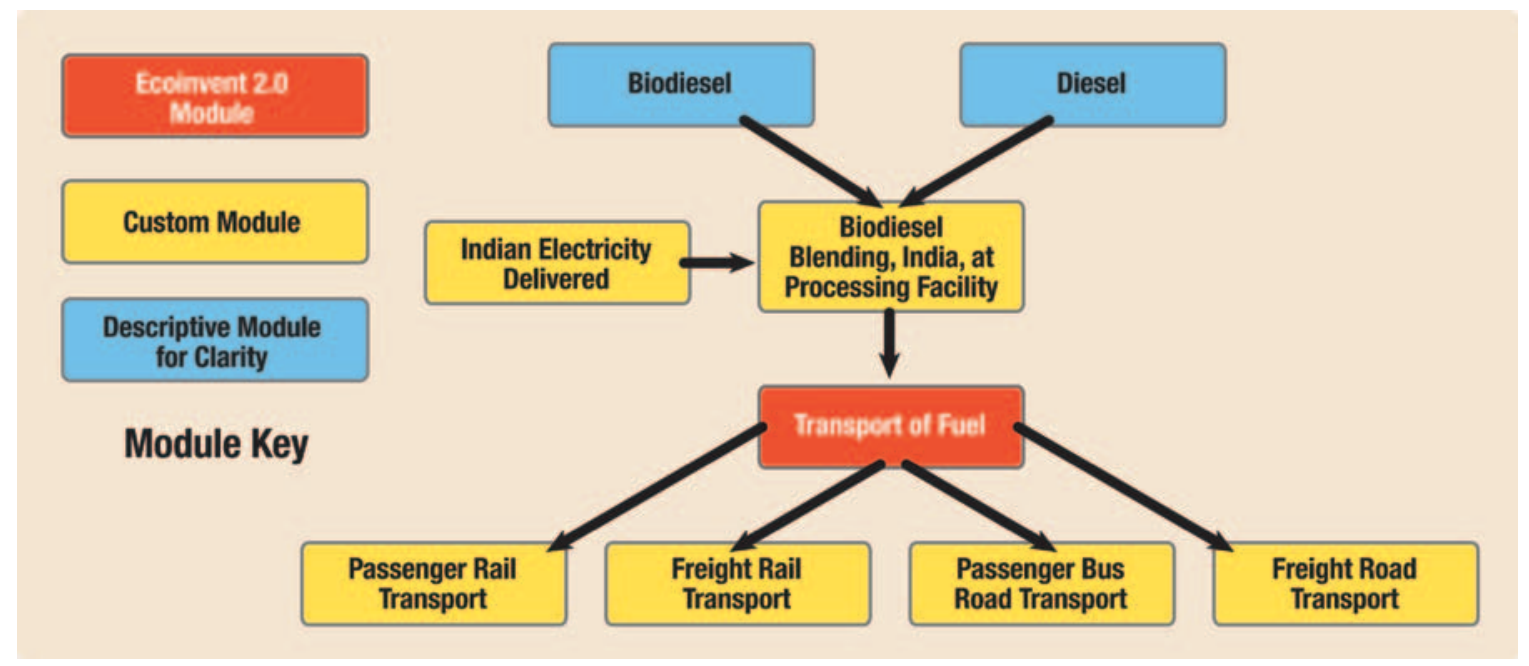

Figure 14. Modeling schematic for transport vehicle operation

Table 10. SimaPro module descriptions for vehicle operation

Module Name
Indian Electricity
Delivered
Biodiesel Blending,
India, At Processing
Facility

Fuel Transport

Passenger-rail Transport

Freight-rail Transport

Passenger BusRoad Transport

Freight-Road Transport

Module Purpose
This custom module represents the Indian electric grid
mix supplied to the biodiesel blending unit.
mix supplied to the biodiesel blending unit.

This custom module calls biodiesel from the transesterification plant and diesel fuel at regional storage and blends them using Indian electricity into the desired mix for the analysis.

This ecoinvent 2.0 module calculates the impacts of transporting the blended biodiesel a short distance via truck from the Bhilai depot to the fueling location for fueling locomotives (freight and passenger), trucks, and buses.

This custom module calls the required amount of blended biodiesel to operate a passenger locomotive over the entire life cycle. Carbon dioxide emissions from the diesel portion of the blended biodiesel are also calculated in this module.

This custom module calls the required amount of blended biodiesel to operate a freight locomotive over the entire life cycle. Carbon dioxide emissions from the diesel portion of the blended biodiesel are also calculated in this module.

This custom module calls the required amount of blended biodiesel to operate a bus over the entire life cycle. Carbon dioxide emissions from the diesel portion of the blended biodiesel are also calculated in this module.

This custom module calls the required amount of blended biodiesel to operate a truck over the entire life cycle. Carbon dioxide emissions from the diesel portion of the blended biodiesel are also calculated in this module.
Comments

See Section 4.6 for more details on the Indian Electricity module.

Analyzed biodiesel blends include $0 \%$, $5 \%, 10 \%, 20 \%$, and $100 \%$.

Blended biodiesel transport has a small impact in the overall life cycle.

The base case analysis assumes an operating lifetime of 2 billion GTK.

The base case analysis assumes an operating lifetime of 2 billion GTK.

The base case analysis assumes an operating lifetime of 2 billion GTK.

The base case analysis assumes an operating lifetime of 2 billion GTK. 
Table 11. Base case data inputs for transport vehicle operation

\begin{tabular}{|c|c|c|c|c|}
\hline Parameter & Value & Units & Assumptions/Notes & Source \\
\hline Biodiesel Blend & $\begin{array}{l}0.0 \\
0.05 \\
0.1 \\
0.2, \\
1.0\end{array}$ & $\begin{array}{l}\text { Fraction biodiesel by } \\
\text { volume }\end{array}$ & $\begin{array}{l}\text { Base analysis covers } 0 \%, 5 \%, 10 \%, 20 \% \text {, and } 100 \% \\
\text { biodiesel blends. }\end{array}$ & $\begin{array}{l}\text { Sarin 2008a; Kathpal } \\
2008\end{array}$ \\
\hline Biodiesel Efficiency & 0 & $\begin{array}{l}\text { Fractional reduction in } \\
\text { fuel economy due to } \\
\text { biodiesel blend }\end{array}$ & $\begin{array}{l}\text { Preliminary IR field trials showed a negligible negative } \\
\text { effect in volumetric fuel consumption for B5, B10, and B20 } \\
\text { (checked through sensitivity analysis). }\end{array}$ & $\begin{array}{l}\text { Kathpal 2008; Skinner et } \\
\text { al. } 2007 \text {; Basha et al. } \\
2009\end{array}$ \\
\hline $\begin{array}{l}\text { Calorific Value } \\
\text { Biodiesel }\end{array}$ & 39,500 & $\mathrm{~kJ} / \mathrm{kg}$ & \multirow{2}{*}{$\begin{array}{l}\text { Estimated calorific values of biodiesel and diesel provided } \\
\text { by IOC. Used to normalize results per fuel energy } \\
\text { delivered }\end{array}$} & \multirow{2}{*}{ Sarin $2008 a$} \\
\hline $\begin{array}{l}\text { Calorific Value } \\
\text { Diesel }\end{array}$ & 42,000 & $\mathrm{~kJ} / \mathrm{kg}$ & & \\
\hline $\begin{array}{l}\text { Specific Gravity } \\
\text { Biodiesel }\end{array}$ & 0.88 & kg/liter & $\begin{array}{l}\text { Specific gravity of } 100 \% \text { biodiesel used in model } \\
\text { conversions }\end{array}$ & $\begin{array}{l}\text { Planning Commission } \\
\text { 2003; Gubler } 2006\end{array}$ \\
\hline $\begin{array}{l}\text { Specific Gravity } \\
\text { Diesel }\end{array}$ & 0.84 & kg/liter & $\begin{array}{l}\text { Specific gravity of diesel fuel used in the model } \\
\text { conversions }\end{array}$ & $\begin{array}{l}\text { Planning Commission } \\
\text { 2003;Gubler } 2006\end{array}$ \\
\hline $\begin{array}{l}\text { Diesel Fuel } \\
\text { Consumption } \\
\text { (Freight Locomotive) }\end{array}$ & 2.63 & liters diesel/1,000 GTK & $\begin{array}{l}\text { Average fuel consumption for Indian Railways freight } \\
\text { trains; gross tonnage includes weight of both train and } \\
\text { cargo }\end{array}$ & Indian Railways 2008 \\
\hline $\begin{array}{l}\text { Diesel Fuel } \\
\text { Consumption } \\
\text { (Passenger } \\
\text { Locomotive) }\end{array}$ & 4.38 & liters diesel/1,000 GTK & $\begin{array}{l}\text { Average fuel consumption for Indian Railways passenger } \\
\text { trains; gross tonnage includes weight of both train and } \\
\text { passengers }\end{array}$ & Indian Railways 2008 \\
\hline $\begin{array}{l}\text { Diesel Fuel } \\
\text { Consumption (Long } \\
\text { Distance Truck) }\end{array}$ & 12.8 & liters diesel/1,000 GTK & $\begin{array}{l}\text { Average fuel consumption for long distance trucks based } \\
\text { on European data used for base case; urban trucks } \\
\text { consume approximately } 28.8 \text { liters diesel/1,000 GTK. }\end{array}$ & $\begin{array}{l}\text { European Automobile } \\
\text { Manufacturers } \\
\text { Association 2009, p. } 6\end{array}$ \\
\hline $\begin{array}{l}\text { Diesel Fuel } \\
\text { Consumption (Bus) }\end{array}$ & 3.94 & kilometers/liter & $\begin{array}{l}\text { Average fuel consumption for the bus fleet in Chennai, } \\
\text { India }\end{array}$ & $\begin{array}{l}\text { Metropolitan Transport } \\
\text { Corporation Chennai } \\
\text { 2009a }\end{array}$ \\
\hline
\end{tabular}




\begin{tabular}{|c|c|c|c|c|}
\hline Parameter & Value & Units & Assumptions/Notes & Source \\
\hline $\begin{array}{l}\text { Bus Operational } \\
\text { Weight }\end{array}$ & 15 & Tonnes & $\begin{array}{l}\text { Operational weight of bus plus passengers for typical } \\
\text { Indian transit bus }\end{array}$ & $\begin{array}{l}\text { Metropolitan Transpor } \\
\text { Corporation Chennai } \\
\text { 2009b; Whitaker } 2007\end{array}$ \\
\hline $\begin{array}{l}\text { Diesel Fuel } \\
\text { Consumption (Bus) }\end{array}$ & 16.9 & liters diesel/1,000 GTK & $\begin{array}{l}\text { Fuel consumption for passenger bus converted to fuel } \\
\text { consumption per } 1,000 \mathrm{GTK} \text { based on bus weight and fuel } \\
\text { consumption per kilometer }\end{array}$ & Calculated \\
\hline $\begin{array}{l}\text { Lifetime Gross } \\
\text { Tonne Kilometers } \\
\text { (GTK) }\end{array}$ & $\begin{array}{c}2 \\
\text { billion }\end{array}$ & $\begin{array}{l}\text { Total GTK analyzed } \\
\text { over vehicle life cycle }\end{array}$ & $\begin{array}{l}\text { Lifetime GTK calculated based on assumption of a } 20-y r \text {. } \\
\text { system lifetime and average operation of Indian Railways } \\
\text { locomotives of } 100 \text { million GTK per year; the functional } \\
\text { unit for this study is } 1,000 \text { GTK. }\end{array}$ & Indian Railways 2008 \\
\hline $\begin{array}{l}\text { Diesel } \mathrm{CO}_{2} \text { Emission } \\
\text { Factor }\end{array}$ & 2.68 & $\begin{array}{l}\mathrm{kg} \mathrm{CO}_{2} / \text { liter of diesel } \\
\text { combusted }\end{array}$ & $\begin{array}{l}\mathrm{CO}_{2} \text { emission factor for the combustion of diesel fuel in } \\
\text { road and rail vehicles }\end{array}$ & $\begin{array}{l}\text { The Climate Registry } \\
2008\end{array}$ \\
\hline $\begin{array}{l}\text { Biodiesel } \mathrm{CO}_{2} \\
\text { Emission Factor }\end{array}$ & 0 & $\begin{array}{l}\mathrm{kg} \mathrm{CO}_{2} / \mathrm{liter} \text { of biodiesel } \\
\text { combusted }\end{array}$ & $\begin{array}{l}\text { Combustion of } 100 \% \text { biodiesel assumed to emit no } \mathrm{CO}_{2} \\
\text { emissions to account for the carbon sequestered in } \\
\text { Jatropha during cultivation }\end{array}$ & By definition \\
\hline
\end{tabular}




\subsection{Supporting Processes}

Many of the biodiesel processes, including cultivation, oil extraction, and transesterification, require supporting processes such as generation of electricity or transportation of goods. Many of the supporting processes (e.g. electricity generation and steam production) rely heavily on the direct combustion of fossil fuels leading them to be significant contributors to the life cycle GHG emissions for biodiesel production and use. An Indian-specific electricity-generation profile was created based on the national average annual proportion of electricity generation by fuel type. The impacts of each generating technology were calculated using ecoinvent 2.0 data modules as outlined in Figure 15 and described in Table 12. European electricity-generation technologies were used as proxies for Indian-specific plants owing to lack of Indian data. However, because the vast majority of life cycle greenhouse gas emissions and energy use - at least for combustion systems - are inherent characteristics of the fuels rather than of the generation technologies, estimates based on European technologies should not differ significantly from those in India. In addition, use of Indian data on electricity generation by source provides useful customization (Table 13).

The Indian electric grid suffers from significant electricity transmission and distribution (T\&D) losses. The base case assumes T\&D losses of 32\% and includes impacts from T\&D infrastructure in the calculations to test the potential impact of electricity infrastructure on the results (Indian Central Electricity Authority 2008). The inclusion of the T\&D infrastructure proved to have a negligible impact on model results. Table 14 describes key ecoinvent 2.0 modules for transportation.

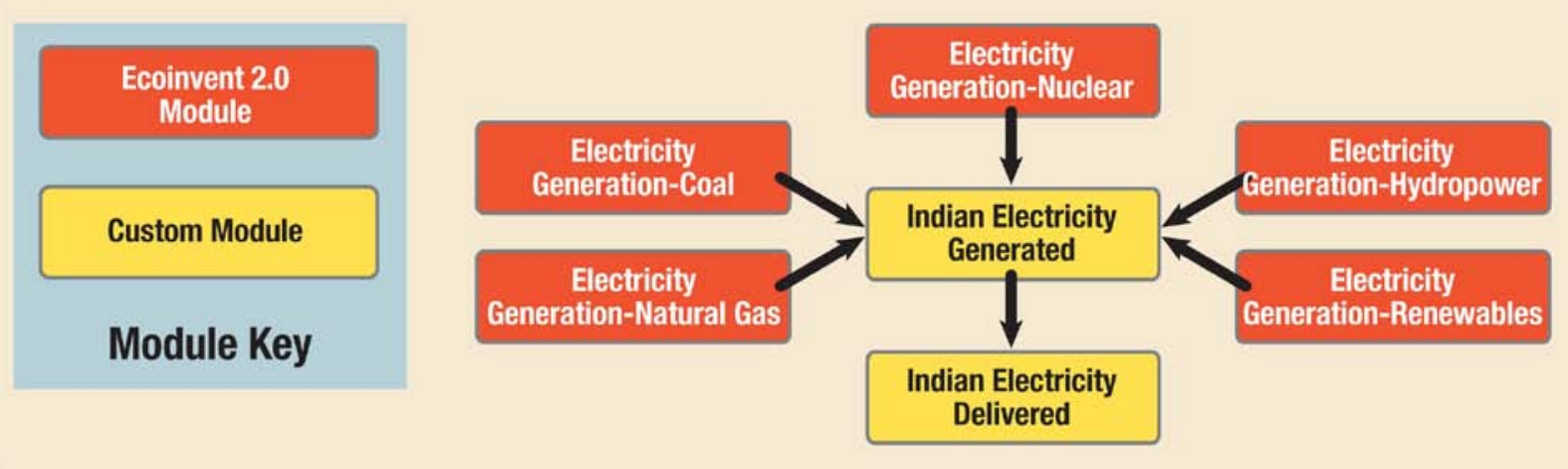

Figure 15. Modeling schematic for Indian electricity 
Table 12. SimaPro module descriptions for Indian electricity

\begin{tabular}{|c|c|c|}
\hline Module Name & Module Purpose & Comments \\
\hline $\begin{array}{l}\text { Electricity } \\
\text { Generation- } \\
\text { Natural Gas }\end{array}$ & $\begin{array}{l}\text { This ecoinvent } 2.0 \text { module calculates } \\
\text { the impacts of electricity generation } \\
\text { from natural gas in Western Europe. } \\
\text { Indian data were unavailable. }\end{array}$ & $\begin{array}{l}\text { The amount of natural gas used in the } \\
\text { Indian Electricity module is based on } \\
\text { average annual electricity generation by } \\
\text { fuel type in India. }\end{array}$ \\
\hline $\begin{array}{l}\text { Electricity } \\
\text { Generation-Coal }\end{array}$ & $\begin{array}{l}\text { This ecoinvent } 2.0 \text { module calculates } \\
\text { the impacts of electricity generation } \\
\text { from coal in Western Europe. Indian } \\
\text { data were unavailable. }\end{array}$ & $\begin{array}{l}\text { The amount of coal used in the Indian } \\
\text { Electricity module is based on average } \\
\text { annual electricity generation by fuel type in } \\
\text { India. }\end{array}$ \\
\hline $\begin{array}{l}\text { Electricity } \\
\text { Generation- } \\
\text { Nuclear }\end{array}$ & $\begin{array}{l}\text { This ecoinvent } 2.0 \text { module calculates } \\
\text { the impacts of electricity generation } \\
\text { from nuclear energy in Western } \\
\text { Europe. Indian data were unavailable. }\end{array}$ & $\begin{array}{l}\text { The amount of nuclear power used in the } \\
\text { Indian Electricity module is based on } \\
\text { average annual electricity generation by } \\
\text { fuel type in India. }\end{array}$ \\
\hline $\begin{array}{l}\text { Electricity } \\
\text { Generation- } \\
\text { Hydropower }\end{array}$ & $\begin{array}{l}\text { This ecoinvent } 2.0 \text { module calculates } \\
\text { the impacts of electricity generation } \\
\text { from hydropower in Western Europe. } \\
\text { Indian data were unavailable. }\end{array}$ & $\begin{array}{l}\text { The amount of hydropower used in the } \\
\text { Indian Electricity module is based on } \\
\text { average annual electricity generation by } \\
\text { fuel type in India. }\end{array}$ \\
\hline $\begin{array}{l}\text { Electricity } \\
\text { Generation- } \\
\text { Renewables }\end{array}$ & $\begin{array}{l}\text { This module calls two ecoinvent } 2.0 \\
\text { modules that calculate the impacts of } \\
\text { electricity generation from solar } \\
\text { photovoltaics and wind energy in } \\
\text { Western Europe. Indian data were } \\
\text { unavailable. }\end{array}$ & $\begin{array}{l}\text { Indian electricity generation data were listed } \\
\text { with renewables as a category. To match } \\
\text { with existing ecoinvent } 2.0 \text { modules, the } \\
\text { authors assumed that } 50 \% \text { of the } \\
\text { renewable electricity came from solar } \\
\text { photovoltaics with the other } 50 \% \text { coming } \\
\text { from wind. }\end{array}$ \\
\hline $\begin{array}{l}\text { Indian Electricity } \\
\text { Generated }\end{array}$ & $\begin{array}{l}\text { This custom module defines the source } \\
\text { mix for Indian electricity using } \\
\text { ecoinvent } 2.0 \text { modules for each } \\
\text { generation type. }\end{array}$ & \\
\hline $\begin{array}{l}\text { Indian Electricity } \\
\text { Delivered }\end{array}$ & $\begin{array}{l}\text { This custom module includes impacts } \\
\text { from T\&D infrastructure and accounts } \\
\text { for transmission and distribution losses } \\
\text { in India. }\end{array}$ & $\begin{array}{l}\text { Transmission and distribution losses in } \\
\text { India on a national average basis are } \\
\text { greater than } 30 \% \text {. }\end{array}$ \\
\hline
\end{tabular}


Table 13. Base case data inputs for Indian electricity*

\begin{tabular}{lcl}
\hline Fuel & \% Generation & Source \\
\cline { 2 - 3 } Coal & $70 \%$ & Indian Central Electricity Authority (2008) \\
Natural Gas & $12 \%$ & U.S. Energy Information Administration (2007b) \\
Hydroelectric & $15 \%$ & U.S. Energy Information Administration (2007b) \\
Nuclear & $2 \%$ & U.S. Energy Information Administration (2007b) \\
Renewable (solar, wind, etc) & $1 \%$ & U.S. Energy Information Administration (2007b) \\
Transmission \& Distribution Loss & $-32 \%$ & Indian Central Electricity Authority (2008) \\
\hline
\end{tabular}

* Impacts from electricity infrastructure are included in the analysis. Transmission \& Distribution Loss refers to national average electricity that is lost between generation and delivery to end users. U.S. Energy Information Administration (2007b) listed thermal energy generation as a combined category. Electricity generation was apportioned to coal and natural gas using the estimated generation capacities listed in Indian Central Electricity Authority (2008).

Table 14. SimaPro module descriptions for transportation of goods

\begin{tabular}{|c|c|c|}
\hline Module Name & Module Purpose & Comments \\
\hline Truck-Lorry & $\begin{array}{l}\text { This ecoinvent } 2.0 \text { module is used to calculate the } \\
\text { impacts of road transport and associated infrastructure } \\
\text { whenever truck transport is required in the model. }\end{array}$ & $\begin{array}{l}\text { Data are for Western } \\
\text { European conditions. India- } \\
\text { specific data were not } \\
\text { available. }\end{array}$ \\
\hline Ocean Tanker & $\begin{array}{l}\text { This ecoinvent } 2.0 \text { module is used to calculate the } \\
\text { impacts of transoceanic transport and associated } \\
\text { infrastructure whenever ocean tanker transport is } \\
\text { required in the model. }\end{array}$ & $\begin{array}{l}\text { Data are for Western } \\
\text { European conditions. India- } \\
\text { specific data were not } \\
\text { available. }\end{array}$ \\
\hline Rail & $\begin{array}{l}\text { This ecoinvent } 2.0 \text { module is used to calculate the } \\
\text { impacts of freight-rail transport and associated } \\
\text { infrastructure whenever railcar transport is required in } \\
\text { the model. }\end{array}$ & $\begin{array}{l}\text { Data are for Western } \\
\text { European conditions. India- } \\
\text { specific data were not } \\
\text { available. }\end{array}$ \\
\hline Pipeline & $\begin{array}{l}\text { This ecoinvent } 2.0 \text { module is used to calculate the } \\
\text { impacts of pipeline transport and associated } \\
\text { infrastructure whenever pipeline transport is required in } \\
\text { the model. }\end{array}$ & $\begin{array}{l}\text { Data are for Western } \\
\text { European conditions. India- } \\
\text { specific data were not } \\
\text { available. }\end{array}$ \\
\hline
\end{tabular}




\section{Normalized Base Case Results}

The base case results are presented using three impact assessment metrics, each normalized to the functional unit of this study of 1,000 GTK:

1. Net greenhouse gas emission intensity - net emissions of the IPCC-identified GHGs calculated with results grouped according to the six Kyoto Protocol gas classifications $\left(\mathrm{CO}_{2}, \mathrm{CH}_{4}, \mathrm{~N}_{2} \mathrm{O}, \mathrm{PFCs}, \mathrm{HFCs}, \mathrm{SF}_{6}\right)$ expressed in carbon dioxide equivalents (kilograms $\mathrm{CO}_{2}$ e per $\left.1,000 \mathrm{GTK}\right)$.

2. Net energy value - useful fuel energy delivered to the transport vehicle minus cumulative energy demand of the system including offsets (Farrell et al. 2006). Net energy ratio (useful fuel energy delivered to the transport vehicle divided by the cumulative energy demand of the system) is de-emphasized but is presented for the base case to enable comparison with Whitaker and Heath (2009) and other biodiesel LCA studies.

3. Petroleum consumption and displacement intensity — crude oil consumption and displacement (kilograms crude oil per 1,000 GTK) for the biodiesel analysis scenarios compared with the conventional diesel baseline.

Base case results are presented for conventional diesel and biodiesel blends of B5, B10, and B20. Results for B100 (neat biodiesel), although not envisioned for use in the Indian transport system, are shown for informational purposes and to enable the reader to calculate results for other blends (by the linearly proportional combination of results for conventional diesel and B100). Section 7 explores the relative influence of certain key parameters.

\subsection{Net Greenhouse Gas Emissions}

Table 15 presents the net life cycle GHG emissions normalized by the functional unit of the study (1,000 GTK). The percent change for each biodiesel blend compared with conventional diesel is also reported. The results suggest that, for the case considered and without considering the impact of land-use change or soil carbon sequestration, all modes and blends yield significant GHG-emission benefits over conventional diesel fuel use. Proportional reduction ("percent change from diesel") is constant for all modes because the point of comparison is diesel fuel used in the same system and used with the same fuel economy. Thus, life cycle GHG emissions will decrease by approximately $3.4 \%$ for B, $6.8 \%$ for B10, $14 \%$ for $\mathrm{B} 20$ and $72 \%$ for B100 compared with conventional diesel emissions. Note that, as expected, GHG emission reductions trend proportionally with increasing biodiesel blend percent. The absolute GHG emissions for each transport vehicle are strongly dependent on the fuel consumption of the mode. As shown in Table 11, freight-rail transport is the most fuel-efficient mode followed by passenger-rail transport, freight-road transport, and passenger-road transport. The influence of the fuel economy on the life cycle GHG emissions is reflected in the results displayed in Table 15. 
Table 15. Comparison of net life cycle GHG emission intensity $\left(\mathrm{kg} \mathrm{CO}_{2} \mathrm{e}\right.$ per $\left.1,000 \mathrm{GTK}\right)$ for the base cases for each of the four transport modes evaluated in this study*

\begin{tabular}{lccccc}
\hline & Diesel & B5 & B10 & B20 & B100 \\
\cline { 2 - 6 } Rail Transport-Freight & 7.9 & 7.6 & 7.4 & 6.8 & 2.3 \\
Rail Transport-Passenger & 13 & 13 & 12 & 11 & 3.8 \\
Road Transport-Freight & 39 & 37 & 36 & 33 & 11 \\
Road Transport-Passenger & 51 & 49 & 47 & 44 & 15 \\
\hline Percent Change from Diesel $^{* *}$ & - & $-3.4 \%$ & $-6.8 \%$ & $-14 \%$ & $-72 \%$ \\
\hline
\end{tabular}

* The reported results assume a 20 -year system lifetime with 2 billion GTK transported over that time. The study employs IPCC (2007) GWP values. Results are rounded to two significant figures as an indication of their uncertainty. ${ }^{* *}$ Percent change from the diesel reference system is constant for all transport modes as it is due to variations in the wells-to-pump portion of the life cycle, assuming that the fuel economy decrement (biodiesel compared to diesel) does not vary by transport mode (Kathpal 2008, Basha et al. 2009). The percent changes reported here may not equal those achieved by calculation using the results reported above owing to independent rounding.

Jatropha biodiesel has a significant GHG-emission benefit compared to petroleum diesel, according to the analysis of the base case conditions considered in this study and without considering the impacts of land-use change or soil carbon sequestration. Table 16 shows these results on the basis of one $\mathrm{MJ}$ of fuel combusted in the vehicle to remove the influence of the fuels' end use efficiency in the various transport vehicles. This analysis can be deemed well-topump (WTP) as it includes all biodiesel and diesel stages required to produce, transport, and deliver the fuels to the pump. For GHG-emission calculations, the carbon content of the fuels delivered to the vehicles is included in the analysis to account for the study methodology, which assigns no carbon credit to Jatropha biodiesel for plant growth but which also assumes no $\mathrm{CO}_{2}$ emissions from biodiesel combustion. Carbon contents of diesel and biodiesel must be included in the WTP analysis in order to compare GHG emission on an equal basis. The results reported in Table 15, as well as all subsequent calculations that are presented on a per 1,000 GTK basis, include operation of the vehicles and the associated differences in fuel economies for the analyzed transport modes. The percent changes from diesel are identical in Table 15 and Table 16 because all GHG-emission differences stem from the fuel processing and delivery portion of the life cycle and not the vehicle operation phase (under base case conditions).

Table 16. Well-to-pump GHG emissions $\left(\mathrm{g} \mathrm{CO}_{2} \mathrm{e} / \mathrm{MJ}\right.$ fuel) for Jatropha biodiesel and conventional diesel plus carbon content of fuel

\begin{tabular}{lcllll}
\hline & Diesel & B5 & B10 & B20 & B100 \\
\cline { 2 - 6 } GHG Emission Intensity & 85 & 82 & 79 & 74 & 24 \\
Percent Change from Diesel & - & $-3.4 \%$ & $-6.8 \%$ & $-14 \%$ & $-72 \%$ \\
\hline
\end{tabular}

The results shown in Table 15 and Table 16 demonstrate that net GHG emissions reductions compared to petroleum diesel are proportional to the biodiesel content of the fuel. This result is mainly a consequence of the modeling assumption that all $\mathrm{CO}_{2}$ emitted during combustion of biodiesel in vehicles are offset by $\mathrm{CO}_{2}$ uptake during growth of the Jatropha plants (assuming non- $\mathrm{CO}_{2} \mathrm{GHG}$ emissions from biodiesel combustion are negligible), whereas considerable $\mathrm{CO}_{2}$ is emitted during combustion of diesel fuel by the vehicles. 
Also, identifying the life cycle processes responsible for the greatest contribution of GHG emissions is informative. Identifying key processes can better focus sensitivity analyses to test the assumptions in those modules and to determine which parameters are likely to be critical in potentially changing the conclusions of the study. As Table 17 shows, vehicle operations are responsible for $89 \%$ of diesel life cycle GHG emissions trending down to $83 \%$ for $\mathrm{B} 20$. Vehicle operations account for $0 \%$ of the B $100 \mathrm{GHG}$ emissions because biodiesel combustion in vehicles is assumed to be carbon neutral over the life cycle, as explained in Section 3.

Table 17. Life cycle GHG process contributions by fuel blend*

\begin{tabular}{lccccr}
\hline Process & Diesel & B5 & B10 & B20 & B100 \\
\cline { 2 - 6 } Vehicle Operations & $89 \%$ & $88 \%$ & $86 \%$ & $83 \%$ & $0 \%$ \\
$\begin{array}{l}\text { Fuel Production and } \\
\text { Processing }\end{array}$ & $11 \%$ & $12 \%$ & $14 \%$ & $17 \%$ & \multirow{2}{*}{$100 \%$} \\
\cline { 2 - 6 } * These results are independent of the vehicle transport mode. & & & &
\end{tabular}

To better understand the life cycle processes that contribute most to the net GHG emissions, Table 18 and Table 19 respectively report process contribution results for biodiesel and conventional diesel with the influence of the vehicle operations stage removed. For biodiesel, Table 18 shows the process contributions to the field-to-pump GHG emissions (defined by the life cycle excluding vehicle operation) because the vehicle operation stage does not add any GHG emissions to the results. Note that the energy used for fertilizer application is assumed to be the same for both chemical fertilizer and Jatropha seed cake. For diesel, Table 19 displays the process contributions that comprise the $11 \%$ of life cycle GHG emissions that are emitted during the fuel production and processing phases. 
Table 18. Contributions to field-to-pump (life cycle excluding vehicle operation) GHG emissions for biodiesel production from Jatropha*

\begin{tabular}{lc}
\hline Process & Percent Contribution \\
\cline { 2 - 2 } Jatropha Cultivation & $16 \%$ \\
$\mathrm{~N}_{2}$ O Release from Fertilizer & $22 \%$ \\
Irrigation & $0.30 \%$ \\
Fertilizer Application & $4.5 \%$ \\
Net Contribution of Chemical Fertilizer Production Minus Offsets & \\
$\quad$ from Use of Jatropha Seed Cake as a Chemical Fertilizer & $-11 \%$ \\
$\quad$ Substitute & \\
Jatropha Oil Extraction & $1.2 \%$ \\
Hexane Production (accounting for recycling) & $1.2 \%$ \\
Base-catalyzed Transesterification & $-30 \%$ \\
Methanol Production (accounting for recycling) & $8.4 \%$ \\
Potassium Hydroxide Production & $3.6 \%$ \\
Glycerine Offset & $-42 \%$ \\
Supporting Processes & $110 \%$ \\
Indian Electricity (including offset from combustion of trimmings) & $55 \%$ \\
Truck Transport & $2.5 \%$ \\
Steam Production & $43 \%$ \\
Diesel Fuel & $5.0 \%$ \\
Tap Water & $1.3 \%$ \\
\hline
\end{tabular}

${ }^{*}$ Percent contributions for each process to total GHG emissions are displayed. Negative percentages represent emission credits due to boundary expansion (co-product offsets). Column totals may not sum to $100 \%$ because of rounding and contributions of minor processes throughout the life cycle. Indian electricity and steam production contribute to impacts for multiple life cycle stages but are aggregated separately because of model limitations. Results are rounded to two significant figures as an indication of their uncertainty.

The results in Table 18 are separated into four main categories: Jatropha cultivation, Jatropha oil extraction, base-catalyzed transesterification, and supporting processes. Positive percentages contribute to the total net GHG emissions while negative percentages indicate credits that are deducted from net GHG emissions.

Supporting processes are the largest contributors to net GHG emissions. These processes include resources - such as Indian electricity, truck transport, steam production, diesel fuel usage in agricultural equipment and other engines - that are used across multiple modules and tend to require the direct combustion of fossil fuels resulting in GHG emissions. The modeling and reporting in SimaPro 7.1 makes it difficult to partition these impacts to individual processes such as oil extraction and transesterification, but the results highlight the importance of minimizing these inputs wherever possible in order to achieve GHG-emission reductions.

The primary contributor to GHG emissions from the cultivation life cycle stage is volatilization of gaseous $\mathrm{N}_{2} \mathrm{O}$ following the application of chemical nitrogen fertilizer, accounting for approximately $22 \%$ of field-to-pump GHG emissions associated with the production of Jatropha biodiesel. The impact of uncertainty in the rate of $\mathrm{N}_{2} \mathrm{O}$ emissions on life cycle $\mathrm{GHG}$ emissions is further tested in Section 7. Mechanical fertilizer application accounts for less than 5\% of field-topump GHG emissions, while fertilizer production actually leads to a GHG-emission offset as credit is taken for the use of Jatropha seed cake to offset the production of inorganic fertilizers. The application of irrigation water accounts for less than $1 \%$ of field-to-pump GHG emissions. 
Hexane production for Jatropha oil extraction contributes just over 1\% to field-to-pump GHG emissions. (The electricity and steam required to operate the Jatropha oil solvent extraction process are accounted for as supporting processes.) The production processes for methanol and potassium hydroxide for base-catalyzed transesterification are energy intensive and combine to account for nearly $12 \%$ of field-to-pump GHG emissions. Significant GHG-emission credits are realized from offsetting the production of synthetic glycerine with the glycerine that is produced from the refining of the glycerol produced during biodiesel transesterification.

Table 19. Process contributions to well-to-pump GHG emissions for the production and distribution of diesel fuel (vehicle operation excluded)

\begin{tabular}{lc}
\hline Process & Percent Contribution \\
\hline Crude Oil & $31 \%$ \\
Crude Oil Extraction & $24 \%$ \\
Crude Oil Ocean Tanker Transport & $7.2 \%$ \\
Diesel Refining & $59 \%$ \\
Diesel Distribution and Fueling & $10 \%$ \\
\hline
\end{tabular}

As a reminder, the GHG emissions shown in Table 19 represent only $11 \%$ of the well-to-pump GHG emissions for conventional diesel production and use. Within this context, diesel refining emits the highest proportion of GHGs, accounting for nearly $60 \%$, with diesel distribution and fueling accounting for only about $10 \%$. The remaining GHG emissions are from the extraction and transport of crude oil from both the Middle East and from offshore at the Bombay High oil field.

Analyzing the proportionate contribution of each major GHG to net carbon dioxide equivalent emissions and examining how those contributions vary across different biodiesel blends is also informative. The results in Table 20 are presented on a WTP basis to remove the influence of fuel combustion in vehicle operation phase, which almost exclusively emits $\mathrm{CO}_{2}$. The goal is to better understand the proportional contribution of various GHGs throughout the production and processing of both Jatropha biodiesel and conventional diesel. The categories of gases considered in this analysis include $\mathrm{CO}_{2}, \mathrm{CH}_{4}, \mathrm{~N}_{2} \mathrm{O}, \mathrm{PFCs}, \mathrm{HFCs}$, and $\mathrm{SF}_{6}$.

Table 20. Contribution by GHG to well-to-pump life cycle global warming potential*

\begin{tabular}{lccccc}
\hline Greenhouse Gas & Diesel & B5 & B10 & B20 & B100 \\
\cline { 2 - 6 } $\mathrm{CO}_{2}$ & $93 \%$ & $90 \%$ & $88 \%$ & $85 \%$ & $71 \%$ \\
$\mathrm{CH}_{4}$ & $6.6 \%$ & $6.5 \%$ & $6.4 \%$ & $6.3 \%$ & $5.7 \%$ \\
$\mathrm{~N}_{2} \mathrm{O}$ & $0.66 \%$ & $3.2 \%$ & $5.4 \%$ & $9.2 \%$ & $24 \%$ \\
$\mathrm{HFCs}, \mathrm{PFCs}, \mathrm{SF}_{6}$ (combined) & $0.13 \%$ & $0.11 \%$ & $0.088 \%$ & $0.054 \%$ & $-0.076 \%$ \\
\hline
\end{tabular}

* Percentages are based on carbon dioxide equivalents using global warming potentials from IPCC 2007 as shown in Table 1. Results are rounded to two significant figures as an indication of their uncertainty.

As shown in Table 20, $\mathrm{CO}_{2}$ has the greatest contribution in all scenarios, as would be expected for a life cycle that heavily relies on combustion of fossil fuels. $\mathrm{CO}_{2}$ contributes from $93 \%$ of well-to-pump GHG emissions for diesel to $71 \%$ for B100. Methane and $\mathrm{N}_{2} \mathrm{O}$ emissions constitute the majority of the remainder depending on the biodiesel blend, where methane emissions are a greater contributor to well/field-to-pump GHG emissions for diesel through B10. 
As the biodiesel blend percentage increases, additional fertilizer is required to grow the seeds to meet the biodiesel demand resulting in greater $\mathrm{N}_{2} \mathrm{O}$ contributions to well/field-to-pump emissions. $\mathrm{N}_{2} \mathrm{O}$ emissions contribute from less than $1 \%$ of total $\mathrm{GHG}$ emissions in the diesel case up to approximately $24 \%$ of well/field-to-pump GHG emissions for B100. This contribution can increase even more if greater volatilization rates of $\mathrm{N}_{2} \mathrm{O}$ from nitrogen fertilizer during plantation operation are assumed. HFCs, PFCs, and $\mathrm{SF}_{6}$ combined contribute less than $0.2 \%$ to well/fieldto-pump GHG emissions for diesel and all biodiesel blends.

\subsection{Net Energy Value}

Net energy value measures whether more useful energy output is realized from a system than is input, accounting for offsets from co-products. As the NEV formula simply subtracts inputs from outputs, whether offsets are added to energy outputs or subtracted from energy inputs is irrelevant. Biologically based products such as Jatropha biodiesel can have positive net energy values because solar energy used for plant growth is not accounted for in the equation. The most desirable systems have positive net energy values; the greater the NEV-even if less negative than an alternative system with a larger negative NEV - the more efficient that system is.

In this study, NEV is calculated as:

$$
\mathrm{NEV}=\text { Energy Out }(\mathrm{MJ})-\text { Net Energy Demand }(\mathrm{MJ})
$$

where, Energy Out is defined as the useful energy delivered to the transport vehicle to produce motion, and Net Energy Demand is defined as all source energy consumed by the system (e.g. fossil, nuclear, renewable) minus energy saved or produced because of system offsets such as biomass combustion.

Table 21 reports the results for the base case.

Table 21: Comparison of NEV (MJ/1,000 GTK) for the base case for each of the four transport modes evaluated in this study*

\begin{tabular}{lllllc}
\hline & Diesel & B5 & B10 & B20 & B100 \\
\cline { 2 - 6 } Rail Transport-Freight & -26 & -22 & -18 & -11 & 52 \\
Rail Transport-Passenger & -42 & -36 & -30 & -18 & 87 \\
Road Transport-Freight & -120 & -110 & -88 & -52 & 250 \\
Road Transport-Passenger & -160 & -140 & -120 & -68 & 340 \\
\hline Percent Change from Diesel $^{* *}$ & - & $14 \%$ & $29 \%$ & $58 \%$ & $300 \%$ \\
\hline
\end{tabular}

* The reported results assume a 20-year system lifetime with 2 billion GTK transported over that time. The study employs IPCC (2007) GWP values. Results are rounded to two significant figures as an indication of their uncertainty. ${ }^{* *}$ Percent change from the diesel reference system is constant for all transport modes as it is due to variations in the wells-to-pump portion of the life cycle, assuming that the fuel economy decrement (biodiesel compared to diesel) does not vary by transport mode (Kathpal 2008, Basha et al. 2009). The percent changes reported here may not equal those achieved by calculation using the results reported above owing to independent rounding.

As shown in Table 21, the B100 results for all four transport modes show positive NEVs, reinforcing the beneficial nature of the Jatropha biodiesel system under base case conditions. As reported in Table 22, Jatropha biodiesel has a WTP-positive NEV of 0.59 MJ/MJ fuel compared to a negative NEV for conventional diesel of $-0.27 \mathrm{MJ} / \mathrm{MJ}$ fuel. As shown in Table 21, the modes that consume more fuel per 1,000 GTK (the road transport modes) will have higher absolute 
values for NEV (positive or negative) than the rail modes as the WTP NEVs in Table 22 are multiplied by the fuel consumed to achieve 1,000 GTK of transport.

Table 22. Well-to-pump NEV (MJ net energy value*) for the base case scenario

\begin{tabular}{lccccc}
\hline & Diesel & B5 & B10 & B20 & B100 \\
\cline { 2 - 6 } Net Energy Value & -0.27 & -0.24 & -0.20 & -0.11 & 0.56 \\
Percent Change from Diesel & - & $14 \%$ & $29 \%$ & $58 \%$ & $300 \%$ \\
\hline
\end{tabular}

${ }^{*} \mathrm{MJ}$ net energy value is reported on a per $\mathrm{MJ}$ of fuel energy delivered to vehicle basis.

\subsection{Net Energy Ratio}

Net energy ratio (NER) is de-emphasized in this report because of the instability of results and lack of uniform calculation method leading to incomparability of NER results across studies. Nevertheless, its intuitive meaning finds broad appeal, and it is calculated here (with results reported in Table 23) to enable comparison with other studies (e.g., Whitaker and Heath 2009). The following section describing the NER is adapted from Whitaker and Heath (2009).

The net energy ratio is used to compare the useful energy produced by the system to the net energy consumed by the system. As described in the supporting materials to Farrell et al. (2006), NER is a problematic metric. Chiefly, the NER is problematic because it is difficult to compare between studies as it is often poorly defined and is strongly influenced by the analyst's method of calculation such as whether energy offsets produced by the system are added to the energy output or subtracted from the energy input.

In this study, NER is calculated as

$$
\mathrm{NER}=\frac{\text { Energy Out }(\mathrm{MJ})}{\text { Net Energy Demand (MJ) }}
$$

where, Energy Out is defined as the useful energy delivered to the transport vehicle to produce motion, and Net Energy Demand is defined as all energy consumed by the system minus energy saved or produced because of system offsets such as biomass combustion. 
Table 23. Net energy ratio evaluated at the point of refueling a vehicle (excluding vehicle operation)*

\begin{tabular}{lccccr}
\hline & Diesel & B5 & B10 & B20 & B100 \\
\cline { 2 - 6 } Net Energy Ratio & 0.78 & 0.81 & 0.84 & 0.90 & 2.3 \\
Percent Change from Diesel $^{* *}(\%)$ & - & $3.2 \%$ & $6.7 \%$ & $14 \%$ & $190 \%$ \\
\hline
\end{tabular}

* The reported results assume a 20-year system lifetime with 2 billion GTK transported over that time. The study employs IPCC (2007) GWP values. Results are rounded to two significant figures as an indication of their uncertainty. ** Percent change from the diesel reference system is constant for all transport modes as it is due to variations in the wells-to-pump portion of the life cycle, assuming that the fuel economy decrement (biodiesel compared to diesel) does not vary by transport mode (Kathpal 2008, Basha et al. 2009)

As Table 23 shows, conventional diesel has a NER of only 0.78 while the NER for B100 is approximately 2.3. Whitaker and Heath (2009) estimated an NER of 1.9. The difference in NER between the two studies results from a decrease in the assumed irrigation requirement for the present study compared to the previous and other small modeling changes, further discussed in Section 6.

\subsection{Net Petroleum Displacement}

Biodiesel use is often cited as a means to decrease dependence on petroleum. This issue is of particular importance to India as approximately $75 \%$ of all crude oil used in India is imported (Sarin 2008e). Reduction in petroleum use is defined as the net consumption of petroleum (including accounting for co-products) by the reference system (here, diesel) minus the net petroleum consumption in an alternative scenario (here, various biodiesel blends), often termed petroleum displacement. By examining petroleum displacement over the full life cycle, this study analyzes to what degree the reduction in combustion of diesel fuel in the transport vehicles is offset by petroleum consumption during the cultivation of Jatropha and transportation and processing of Jatropha oil and biodiesel. Table 24 shows petroleum consumption and displacement over the life cycle normalized by the functional unit, 1,000 GTK. The percent decrease in petroleum consumption compared with the conventional diesel base case is also tabulated. 
Table 24. Comparison of net life cycle petroleum consumption and displacement intensities (kg crude oil/1,000 GTK) for the base case for each of four transport modes evaluated in this study*

\begin{tabular}{lccccc}
\hline & Diesel & B5 & B10 & B20 & B100 \\
\cline { 2 - 6 } & 2.5 & 2.4 & 2.3 & 2.1 & 0.30 \\
$\begin{array}{l}\text { Rail Transport-Freight } \\
\text { Net Petroleum }\end{array}$ & - & 0.10 & 0.21 & 0.42 & 2.2 \\
$\begin{array}{l}\text { Nensumption Intensity } \\
\text { Displacement Intensity }\end{array}$ & & & & & \\
$\begin{array}{l}\text { Rail Transport-Passenger } \\
\text { Net Petroleum }\end{array}$ & 4.1 & 4.0 & 3.8 & 3.4 & 0.50 \\
$\begin{array}{l}\text { Consumption Intensity } \\
\text { Net Petroleum }\end{array}$ & - & 0.17 & 0.35 & 0.70 & 3.6 \\
$\begin{array}{l}\text { Displacement Intensity } \\
\text { Road Transport-Freight }\end{array}$ & 12 & 12 & 11 & 10 & 1.5 \\
$\begin{array}{l}\text { Net Petroleum } \\
\text { Consumption Intensity }\end{array}$ & - & 0.51 & 1.0 & 2.0 & 11 \\
$\begin{array}{l}\text { Net Petroleum } \\
\text { Displacement Intensity }\end{array}$ & & & & & 1.9 \\
$\begin{array}{l}\text { Road Transport-Passenger } \\
\text { Net Petroleum }\end{array}$ & 16 & 15 & 15 & 13 & 14 \\
$\begin{array}{l}\text { Consumption Intensity } \\
\text { Net Petroleum } \\
\text { Displacement Intensity }\end{array}$ & - & 0.67 & 1.3 & 2.7 & 14 \\
\hline $\begin{array}{l}\text { Percent Change from Diesel** } \\
\text { Net Petroleum } \\
\text { Consumption Intensity }\end{array}$ & - & $-4.2 \%$ & $-8.4 \%$ & $-17 \%$ & $-88 \%$ \\
\hline
\end{tabular}

* The reported results assume a 20-year system lifetime with 2 billion GTK transported over that time. The study employs IPCC (2007) GWP values. Results are rounded to two significant figures as an indication of their uncertainty. ${ }^{* *}$ Percent change from the diesel reference system is constant for all transport modes as it is due to variations in the wells-to-pump portion of the life cycle, assuming that the fuel economy decrement (biodiesel compared to diesel) does not vary by transport mode (Kathpal 2008, Basha et al. 2009). The percent changes reported here may not equal those achieved by calculation using the results reported above owing to independent rounding.

All four transport modes realize significant reductions in petroleum consumption for all blends of biodiesel compared with conventional petroleum diesel. B5 yields a reduction of $4.2 \%$, with $\mathrm{B} 10, \mathrm{~B} 20$, and $\mathrm{B} 100$ yielding reductions of $8.4 \%, 17 \%$, and $88 \%$ respectively. Table 25 reports the petroleum consumption and petroleum displacement intensity on a WTP basis to remove the influence of vehicle operation efficiency on the results. For base case conditions, all of the reductions in petroleum consumption occur during the WTP phase of the life cycle, as evidenced by the change from diesel results in Table 24 (full life cycle) and Table 25 (WTP only) being identical. 
Table 25. Well-to-pump net petroleum consumption and displacement (g crude oil/MJ fuel delivered) for the base case scenario

\begin{tabular}{lccccc}
\hline & Diesel & B5 & B10 & B20 & B100 \\
\cline { 2 - 6 } Net Petroleum Consumption Intensity & 27 & 26 & 25 & 22 & 3.2 \\
Net Petroleum Displacement Intensity & & 1.1 & 2.3 & 4.5 & 24 \\
\hline $\begin{array}{l}\text { Percent Change from Diesel for Net } \\
\text { Petroleum Displacement Intensity }\end{array}$ & - & $-4.2 \%$ & $-8.4 \%$ & $-17 \%$ & $-88 \%$ \\
\hline
\end{tabular}

It is evident on the basis of the results in Table 24 and Table 25 that replacing conventional diesel with biodiesel blends in India will lead to significant savings in petroleum consumption. Sensitivity analyses are used to test how petroleum savings differ with changes to selected model input parameters. 


\section{Benchmarking}

The base case GHG-emission results of this study are benchmarked against five Jatropha LCA studies. These include the authors' previous report (Whitaker and Heath 2009), the Renewable Fuels Agency's (RFA) analysis (2009), ${ }^{6}$ and Reinhardt et al.'s (2007) study that all examine Jatropha biodiesel production in India, along with Ndong et al.'s (2009) study of Jatropha production in the Ivory Coast in West Africa and Prueksakorn and Gheewala's (2006) analysis of Jatropha production in Thailand. Table 26 summarizes the WTP GHG emissions in grams of $\mathrm{CO}_{2} \mathrm{e}$ per $\mathrm{MJ}$ of biodiesel (B100) or diesel delivered to the vehicle for the above-mentioned studies. Percent reduction in GHG emissions from the conventional petroleum diesel baseline is calculated on a WTP basis (plus the carbon content of the fuel) for each study.

Both Whitaker and Heath studies, along with Reinhardt et al. and Ndong et al., estimate the impacts of the conventional well-to-wheel diesel baseline at 84-87 grams $\mathrm{CO}_{2} \mathrm{e} / \mathrm{MJ}$, which is in line with estimates for conventional and reformulated low sulfur diesel from Argonne National Laboratory's GREET model (Argonne National Laboratory 2009). Prueksakorn and Gheewala use a significantly higher conventional well-to-wheel diesel baseline of 246 grams $\mathrm{CO}_{2} \mathrm{e} / \mathrm{MJ}$ based on the results of Sheehan et al.'s (1998) study of soybean biodiesel and conventional diesel production. Prueksakorn and Gheewala also use Sheehan et al.'s estimates of oil extraction and biodiesel processing energy consumption for soybean oil to apply to Jatropha biodiesel production.

Table 26. Benchmarking the net life cycle GHG-emission results of the present study against results from other published studies

\begin{tabular}{llcc}
\hline Source & Feedstock-Country & $\begin{array}{l}\text { Biodiesel } \\
\text { (B100) GHG } \\
\text { Emissions } \\
\left.\text { (g CO }_{\mathbf{2}} \mathbf{e} / \mathbf{M}\right)\end{array}$ & $\begin{array}{l}\text { \% Reduction in Well- } \\
\text { to-Wheel GHG } \\
\text { Emissions for B100 } \\
\text { Compared with Diesel }\end{array}$ \\
\hline This Study-Base Case Analysis & Jatropha-India & 24 & $72 \%$ \\
Whitaker and Heath (2009) & Jatropha-India & 33 & $62 \%$ \\
Renewable Fuels Agency (2009) & Jatropha-India & 25 & $71 \%$ \\
Reinhardt et al. (2007) & Jatropha-India & 75 & $11 \%$ \\
Ndong et al. (2009) & Jatropha-West Africa & 24 & $72 \%$ \\
Prueksakorn and Gheewala (2006) & Jatropha-Thailand & 57 & $77 \%$ \\
\hline
\end{tabular}

Ndong et al.'s study uses methodology and boundaries similar to this study including (1) considering that all $\mathrm{CO}_{2}$ emitted during biodiesel combustion is offset by carbon uptake during the growth phase of the Jatropha, (2) using a combination of country specific field data and literature searching to fill data gaps, and (3) utilizing the ecoinvent 2.0 database to provide key process modules. WTP GHG-emission results for this study agree closely with results from Ndong et al. The Ndong et al. study uses a similar base case yield of 4 tonnes of dry seed per hectare per year compared with 3.75 tonnes of dry seed per hectare per year for this study.

\footnotetext{
${ }^{6}$ The Renewable Fuels Agency's report establishes GHG emission factors for conventional diesel and renewable fuels for reporting under the United Kingdom's renewable transport fuel obligation and includes country-specific emission factors for multiple fuel types including Jatropha.
} 
The Reinhardt et al. study assumed cultivation on poor soils and a yield of only 1.4 tonnes of dry seed per hectare per year. As explored in Section 7, the net GHG-emission benefit for utilizing Jatropha biodiesel is heavily dependent on the yield achieved per hectare. Therefore, that Reinhardt et al.'s lower yield estimate leads to less of a net GHG-emission benefit for its analysis is unsurprising.

The RFA report provides default GHG-emission values for a wide variety of biofuels that qualify under the United Kingdom's renewable transport fuel obligation. The value listed in Table 26 is the default value for Jatropha biodiesel produced in India, and it agrees closely with the GHGemission results of this study. The RFA study references Reinhardt et al. for cultivation data and uses 2.27 tonnes of seed yield per hectare-year as its default value. On the other hand, it assumes a lower rate of fertilizer input than those suggested by Reinhardt et al. for the optimized scenario (and lower than those used in this study), and it omits diesel fuel consumption for plantation management. Impacts associated with the transport of goods during the production of biodiesel are calculated based on aggregate fuel consumption and modal share of vehicle travel in India.

The diesel GHG-emission estimates in this study and Whitaker and Heath (2009) are the same. The difference in biodiesel GHG emissions is primarily due to a reduction in the assumed irrigation water required. The previous report estimated required irrigation input as the difference between the rainfall at the site and the rainfall for a site known to require no irrigation. Since the LCA model supporting the previous report was frozen, a publication reporting results from Jatropha water requirement experiments was found (Kheira and Atta 2008). The current publication should provide a much more accurate estimate of irrigation demand. It is now believed that the irrigation water requirement estimated in the previous Whitaker and Heath report (2009) was likely overestimated by a factor of more than 100. While the base case scenario only assumed irrigation for three years, this difference in estimated water requirement was still significant enough to account for over $90 \%$ of the difference between the biodiesel GHG-emission estimates for this study and for Whitaker and Heath (2009). The remainder of the difference can be accounted for by minor changes in the modeling: removing a potential double counting of transportation and all transportation infrastructure (to better match the defined scope of the study, which utilizes India's existing transportation infrastructure). 


\section{Sensitivity Analyses}

The sensitivity analyses for this study take two primary approaches. Scenario sensitivity analyses evaluate coherent sets of parameters that define plausible alternative scenarios for Jatropha biodiesel production, distribution, and use in India. Parametric sensitivity analyses vary the values of individual parameters to determine which inputs have the greatest impacts on GHG emissions, NEV, and petroleum displacement.

\subsection{Scenario Sensitivity Analysis}

This section analyzes plausible alternative scenarios for the production of Jatropha biodiesel in India, including alternative co-product offset scenarios, cultivation inputs, and assumed yields. If a specific biodiesel blend is not identified in the subsections that follow, the discussion refers to the results for B100. In comparing sensitivity scenario results to the base case scenario, negative percent changes are considered environmentally beneficial for GHG emissions and petroleum consumption (indicating a reduction in impacts) while positive percent changes are beneficial for NEV (indicating a greater difference between useful energy out of the system and cumulative energy demanded by the system).

\subsubsection{Sensitivity Scenario A: Marginal Land, Low Irrigation}

Much of the uncertainty related to modeling the life cycle production of Jatropha biodiesel resides in the estimation of expected yield of seeds and Jatropha oil from given cultivation inputs. However, certain directional relationships between key cultivation parameters are well known even if an exact quantitative relationship is not well established. For instance, marginal land conditions coupled with no irrigation or less intensive cultivation practices lead to lower seed yields and oil content. Sensitivity scenario A models a $40 \%$ reduction in seed yield compared with the more optimized Jatropha cultivation conditions of the base case scenario. The reduction in seed yield is based on Reinhardt et al.'s (2008) estimate for India's current Jatropha cultivation conditions. Also well known is that omitting irrigation may result in a water deficit for the trees during the growing season. According to Kheira and Atta (2008), sensitivity scenario A models the oil content of Jatropha seeds under water stress as $25 \%$ (compared to the base case estimate of $35 \%$ ). Estimates for parameters in sensitivity scenario A whose values have changed compared to the base case scenario are detailed in Table 27. Table 28, Table 29, and Table 30 report the GHG emission, NEV, and petroleum consumption and displacement intensity results, respectively.

Table 27. Sensitivity scenario A—marginal land, low irrigation-input parameters

\begin{tabular}{lllcc}
\hline Parameter Description & \multirow{2}{*}{ Input Parameter } & Units & $\begin{array}{c}\text { Base Case } \\
\text { Value }\end{array}$ & $\begin{array}{c}\text { Sensitivity } \\
\text { Scenario A }\end{array}$ \\
\cline { 2 - 5 } Years of irrigation required & irr_years & Years & 3 & 0 \\
Jatropha seed oil content & oil_content & Mass fraction & 0.35 & 0.25 \\
Seed yield reduction & seed_yield_red & $\begin{array}{l}\text { Fraction reduction } \\
\text { in seed yield }\end{array}$ & 0 & 0.40 \\
\hline
\end{tabular}


Table 28. Comparison of net life cycle GHG emission intensity $\left(\mathrm{kg} \mathrm{CO}_{2} \mathrm{e} / 1,000 \mathrm{GTK}\right.$ ) for sensitivity scenario A for each of the four transport modes evaluated in this study ${ }^{*}$

\begin{tabular}{|c|c|c|c|c|c|}
\hline & Diesel & B5 & B10 & B20 & B100 \\
\hline Rail Transport-Freight & 7.9 & 7.8 & 7.7 & 7.4 & 5.5 \\
\hline Rail Transport-Passenger & 13 & 13 & 13 & 12 & 9.1 \\
\hline Road Transport-Freight & 39 & 38 & 37 & 36 & 27 \\
\hline Road Transport-Passenger & 51 & 50 & 49 & 48 & 35 \\
\hline $\begin{array}{l}\text { Fuel Delivered to Transport Vehicles } \\
\left(\mathrm{g} \mathrm{CO}_{2} \mathrm{e} / \mathrm{MJ} \text { fuel delivered }\right)\end{array}$ & 85 & 84 & 83 & 80 & 59 \\
\hline Percent Change from Diesel ${ }^{* * *}$ & - & $-1.4 \%$ & $-2.9 \%$ & $-5.9 \%$ & $-31 \%$ \\
\hline Percent Change from Base Case Result ${ }^{\star * *}$ & $0.0 \%$ & $2.0 \%$ & $4.2 \%$ & $9.1 \%$ & $140 \%$ \\
\hline
\end{tabular}

* The reported results assume a 20 -year system lifetime with 2 billion GTK transported over that time. The study employs IPCC (2007) GWP values. Results are rounded to two significant figures as an indication of their uncertainty. ** The system boundaries for this calculation are well to pump plus carbon content of fuel.

${ }^{* * *}$ Percent change from the diesel reference system and from the base case result is constant for all transport modes as it is due to variations in the wells-to-pump portion of the life cycle, assuming that the fuel economy decrement (biodiesel compared to diesel) does not vary by transport mode (Kathpal 2008, Basha et al. 2009). The percent changes reported here may not equal those achieved by calculation using the results reported above owing to independent rounding.

As Table 28 shows, Jatropha biodiesel maintains a net GHG-emission advantage over conventional diesel even if seed yields are reduced by $40 \%$ and oil content of the seeds is reduced from $35 \%$ to $25 \%$. However, the net GHG-emission advantage is reduced from approximately $72 \%$ in the base case to only $31 \%$ under these cultivation conditions.

Similarly, the base case estimate of NEV is negatively impacted by the reduced seed yield and oil content, even after accounting for eliminating irrigation requirements. The NEV of B100 is reduced by $99 \%$ compared with the base case (Table 29 ).

Table 29. Comparison of NEV (MJ/1,000 GTK) for sensitivity scenario A for each of the four transport modes evaluated in this study

\begin{tabular}{|c|c|c|c|c|c|}
\hline & Diesel & B5 & B10 & B20 & B100 \\
\hline Rail Transport-Freight & -26 & -24 & -23 & -21 & 0.39 \\
\hline Rail Transport-Passenger & -42 & -40 & -38 & -34 & 0.65 \\
\hline Road Transport-Freight & -120 & -120 & -110 & -100 & 1.9 \\
\hline Road Transport-Passenger & -160 & -160 & -150 & -130 & 2.5 \\
\hline $\begin{array}{l}\text { Fuel Delivered to Transport Vehicles }{ }^{* *} \\
\text { (MJ net energy benefit / MJ fuel delivered) }\end{array}$ & -0.27 & -0.26 & -0.25 & -0.22 & 0.0042 \\
\hline Percent Change from Diesel ${ }^{\star * *}$ & - & $4.7 \%$ & $10 \%$ & $19 \%$ & $100 \%$ \\
\hline Percent Change from Base Case Result*** & $0.0 \%$ & $-11 \%$ & $-27 \%$ & $-94 \%$ & $-99 \%$ \\
\hline
\end{tabular}

* The reported results assume a 20-year system lifetime with 2 billion GTK transported over that time. The study employs IPCC (2007) GWP values. Results are rounded to two significant figures as an indication of their uncertainty.

** The system boundaries for this calculation are well to pump plus carbon content of fuel.

${ }^{* * *}$ Percent change from the diesel reference system and from the base case result is constant for all transport modes as it is due to variations in the wells-to-pump portion of the life cycle, assuming that the fuel economy decrement (biodiesel compared to diesel) does not vary by transport mode (Kathpal 2008, Basha et al. 2009). The percent changes reported here may not equal those achieved by calculation using the results reported above owing to independent rounding. 
Finally, as expected, petroleum consumption intensity increases as seed yield and oil content decrease (Table 30). For this scenario, petroleum consumption intensity nearly doubles in comparison to the base case, although a reduction in petroleum consumption of approximately $66 \%$ is still achieved compared with conventional diesel.

Table 30. Comparison of net petroleum consumption and displacement intensity for sensitivity scenario A for each of the four transport modes evaluated in this study

\begin{tabular}{|c|c|c|c|c|c|c|}
\hline & Units & Diesel & B5 & B10 & B20 & B100 \\
\hline \multicolumn{7}{|l|}{ Rail Transport-Freight } \\
\hline $\begin{array}{l}\text { Net Petroleum } \\
\text { Consumption Intensity }\end{array}$ & $\begin{array}{l}\text { kg crude oil/ } \\
1,000 \text { GTK }\end{array}$ & 2.5 & 2.4 & 2.3 & 2.2 & 0.84 \\
\hline $\begin{array}{l}\text { Net Petroleum } \\
\text { Displacement Intensity }\end{array}$ & $\begin{array}{l}\text { kg crude oil/ } \\
1,000 \text { GTK }\end{array}$ & - & 0.078 & 0.16 & 0.32 & 1.6 \\
\hline \multicolumn{7}{|l|}{ Rail Transport-Passenger } \\
\hline $\begin{array}{l}\text { Net Petroleum } \\
\text { Consumption Intensity }\end{array}$ & $\begin{array}{l}\text { kg crude oil/ } \\
1,000 \text { GTK }\end{array}$ & 4.1 & 4.0 & 3.9 & 3.6 & 1.4 \\
\hline $\begin{array}{l}\text { Net Petroleum } \\
\text { Displacement Intensity }\end{array}$ & $\begin{array}{l}\text { kg crude oil/ } \\
1,000 \text { GTK }\end{array}$ & - & 0.13 & 0.26 & 0.53 & 2.7 \\
\hline \multicolumn{7}{|l|}{ Road Transport-Freight } \\
\hline $\begin{array}{l}\text { Net Petroleum } \\
\text { Consumption Intensity }\end{array}$ & $\begin{array}{l}\text { kg crude oil/ } \\
1,000 \text { GTK }\end{array}$ & 12 & 12 & 11 & 11 & 4.1 \\
\hline $\begin{array}{l}\text { Net Petroleum } \\
\text { Displacement Intensity }\end{array}$ & $\begin{array}{l}\text { kg crude oil/ } \\
1,000 \text { GTK }\end{array}$ & - & 0.38 & 0.76 & 1.5 & 8.0 \\
\hline \multicolumn{7}{|l|}{ Road Transport-Passenger } \\
\hline $\begin{array}{l}\text { Net Petroleum } \\
\text { Consumption Intensity }\end{array}$ & $\begin{array}{l}\text { kg crude oil/ } \\
1,000 \text { GTK }\end{array}$ & 16 & 15 & 15 & 14 & 5.4 \\
\hline $\begin{array}{l}\text { Net Petroleum } \\
\text { Displacement Intensity }\end{array}$ & $\begin{array}{l}\text { kg crude oil/ } \\
1,000 \text { GTK }\end{array}$ & - & 0.50 & 1.0 & 2.0 & 11 \\
\hline \multicolumn{7}{|l|}{ Fuel Delivered to Transport Vehicles** } \\
\hline $\begin{array}{l}\text { Net Petroleum } \\
\text { Consumption Intensity }\end{array}$ & $\begin{array}{l}\text { g crude oil/ } \\
\text { MJ fuel delivered }\end{array}$ & 27 & 26 & 25 & 23 & 9.1 \\
\hline $\begin{array}{l}\text { Net Petroleum } \\
\text { Displacement Intensity }\end{array}$ & $\begin{array}{l}\text { g crude oil/ } \\
\text { MJ fuel delivered }\end{array}$ & & 0.84 & 1.7 & 3.4 & 18 \\
\hline Percent Change from Diesel ${ }^{* * *}$ & $\%$ & - & $-3.2 \%$ & $-6.3 \%$ & $-13 \%$ & $-66 \%$ \\
\hline $\begin{array}{l}\text { Percent Change from Base Case Value } \\
\text { for Petroleum Consumption Intensity }\end{array}$ & $\%$ & $0.0 \%$ & $1.1 \%$ & $2.3 \%$ & $5.1 \%$ & $180 \%$ \\
\hline
\end{tabular}

* The reported results assume a 20 -year system lifetime with 2 billion GTK transported over that time. The study employs IPCC (2007) GWP values. Results are rounded to two significant figures as an indication of their uncertainty. ** The system boundaries for this calculation are well to pump plus carbon content of fuel.

*** Percent change from the diesel reference system and from the base case value for petroleum consumption intensity is constant for all transport modes as it is due to variations in the wells-to-pump portion of the life cycle, assuming that the fuel economy decrement (biodiesel compared to diesel) does not vary by transport mode (Kathpal 2008, Basha et al. 2009). The percent changes reported here may not equal those achieved by calculation using the results reported above owing to independent rounding. 


\subsubsection{Sensitivity Scenario B: Marginal Land, High Cultivation Maintenance}

This sensitivity scenario tests the impact of increasing cultivation inputs to achieve base case seed yields and oil content on marginal land. The scenario is designed to test whether there is a positive tradeoff when additional fertilizer and irrigation are used to overcome the yield reductions associated with use of marginal land. Table 31 details the parameters used in the sensitivity analysis. Table 32, Table 33, and Table 34 report the GHG emission, NEV, and petroleum consumption results, respectively.

Table 31. Sensitivity scenario B: marginal land, high cultivation maintenance-parameter inputs

\begin{tabular}{lllcc}
\hline Parameter Description & Input Parameter & Units & $\begin{array}{c}\text { Base Case } \\
\text { Value }\end{array}$ & $\begin{array}{c}\text { Sensitivity } \\
\text { Scenario B }\end{array}$ \\
\cline { 2 - 5 } Fraction irrigation needs met & Frac_met_irr & Mass fraction & 0.20 & 0.40 \\
Diesel fuel consumed for & diesel_fuel_cul & liters/ha & 86 & 128 \\
cultivation & $\mathrm{N}$ ffert_req & $\mathrm{kg} \mathrm{N} / \mathrm{ha}-\mathrm{yr}$ & 81 & 124 \\
$\mathrm{~N}$ fertilizer required & $\mathrm{P} 2 \mathrm{O} 5$ _fert_req & $\mathrm{kg} \mathrm{P}_{2} \mathrm{O}_{5} / \mathrm{ha}-\mathrm{yr}$ & 31 & 49 \\
$\mathrm{P}_{2} \mathrm{O}_{5}$ fertilizer required & K2O_fert_req & $\mathrm{kg} \mathrm{K}_{2} \mathrm{O} / \mathrm{ha}-\mathrm{yr}$ & 89 & 128 \\
$\mathrm{~K}_{2} \mathrm{O}$ fertilizer required & & & \\
\hline
\end{tabular}

The increased diesel fuel and fertilizer estimates are based on scaling the optimized scenario inputs of Reinhardt et al. (2008) to achieve the base case yield value of 3,750 kg dry seed per hectare (Planning Commission 2003). While Achten et al. (2008) suggest that oil content of approximately $35 \%$ is achievable even on marginal land, Kheira and Atta (2008) warn that water deficits (often associated with marginal lands) can significantly decrease final oil content. Therefore, the irrigation assumptions of this scenario are increased to twice those of the base case to model a higher cultivation input scenario designed to achieve base case yields and oil content from marginal land.

As Table 33 shows, increasing fertilizer and irrigation to achieve base case yields and oil content from marginal land would result in life cycle GHG emissions decreasing by $59 \%$ compared to conventional diesel, as opposed to decreasing by $72 \%$ as in the base case. As shown later in the parametric sensitivity analysis (Section 7.2), irrigation has a smaller impact on net life cycle GHG emissions compared with other input parameters. Even if irrigation is required for 20 years at the higher level of $40 \%$ of water needs met by irrigation (tested in separate modeling as a contrast with the base case assumption of 3 years of irrigation required for plantation establishment) GHG-emission reductions compared with conventional diesel still exceed 58\%. 
Table 32. Comparison of net life cycle GHG emission intensity ( $\left.\mathrm{kg} \mathrm{CO}_{2} \mathrm{e} / 1,000 \mathrm{GTK}\right)$ for sensitivity scenario $B$ for each of the four transport modes evaluated in this study*

\begin{tabular}{lccccc}
\hline & Diesel & B5 & B10 & B20 & B100 \\
\cline { 2 - 6 } Rail Transport-Freight & 7.9 & 7.7 & 7.5 & 7.0 & 3.2 \\
Rail Transport-Passenger & 13 & 13 & 12 & 12 & 5.4 \\
Road Transport-Freight & 39 & 37 & 36 & 34 & 16 \\
Road Transport-Passenger & 51 & 50 & 48 & 45 & 21 \\
$\begin{array}{l}\text { Fuel Delivered to Transport Vehicles } \\
\text { (g CO } \mathrm{g}_{2} \text { / MJ fuel delivered) }\end{array}$ & 85 & 83 & 81 & 76 & 35 \\
\hline Percent Change from Diesel $^{* * *}$ & - & $-2.8 \%$ & $-5.6 \%$ & $-11 \%$ & $-59 \%$ \\
Percent Change from Base Case Result*** $^{*}$ & $0.0 \%$ & $0.61 \%$ & $1.3 \%$ & $2.8 \%$ & $43 \%$ \\
\hline
\end{tabular}

* The reported results assume a 20-year system lifetime with 2 billion GTK transported over that time. The study employs IPCC (2007) GWP values. Results are rounded to two significant figures as an indication of their uncertainty. ** The system boundaries for this calculation are well to pump plus carbon content of fuel.

*** Percent change from the diesel reference system and from the base case result is constant for all transport modes as it is due to variations in the wells-to-pump portion of the life cycle, assuming that the fuel economy decrement (biodiesel compared to diesel) does not vary by transport mode (Kathpal 2008, Basha et al. 2009). The percent changes reported here may not equal those achieved by calculation using the results reported above owing to independent rounding.

Table 33. Comparison of NEV intensity (MJ/1,000 GTK) for sensitivity scenario $B$ for each of the four transport modes evaluated in this study*

\begin{tabular}{|c|c|c|c|c|c|}
\hline & Diesel & B5 & B10 & B20 & B100 \\
\hline Rail Transport-Freight & -26 & -23 & -20 & -14 & 35 \\
\hline Rail Transport-Passenger & -42 & -38 & -33 & -23 & 58 \\
\hline Road Transport-Freight & -120 & -110 & -96 & -68 & 170 \\
\hline Road Transport-Passenger & -160 & -150 & -130 & -90 & 220 \\
\hline $\begin{array}{l}\text { Fuel Delivered to Transport Vehicles }{ }^{* *} \\
\text { (MJ net energy benefit / MJ fuel delivered) }\end{array}$ & -0.27 & -0.24 & -0.21 & -0.15 & 0.37 \\
\hline Percent Change from Diesel ${ }^{* * *}$ & - & $11 \%$ & $22 \%$ & $45 \%$ & $240 \%$ \\
\hline Percent Change from Base Case Result ${ }^{* * *}$ & $0.0 \%$ & $-3.8 \%$ & $-9.2 \%$ & $-31 \%$ & $-33 \%$ \\
\hline
\end{tabular}

* The reported results assume a 20-year system lifetime with 2 billion GTK transported over that time. The study employs IPCC (2007) GWP values. Results are rounded to two significant figures as an indication of their uncertainty ** The system boundaries for this calculation are well to pump plus carbon content of fuel.

*** Percent change from the diesel reference system and from the base case result is constant for all transport modes as it is due to variations in the wells-to-pump portion of the life cycle, assuming that the fuel economy decrement (biodiesel compared to diesel) does not vary by transport mode (Kathpal 2008, Basha et al. 2009). The percent changes reported here may not equal those achieved by calculation using the results reported above owing to independent rounding.

Table 33 reveals that on a WTP basis, Jatropha biodiesel still maintains a positive NEV if fertilizer and irrigation requirements are increased as shown in Table 31. Finally, as Table 34 reports, petroleum consumption increases by more than $60 \%$ under this scenario, however, Jatropha biodiesel production still results in a reduction in petroleum consumption of approximately $80 \%$ compared with conventional diesel. 
Table 34. Comparison of net petroleum consumption and displacement intensity for sensitivity scenario B for each of the four transport modes evaluated in this study*

\begin{tabular}{|c|c|c|c|c|c|c|}
\hline & Units & Diesel & B5 & B10 & B20 & B100 \\
\hline \multicolumn{7}{|l|}{ Rail Transport-Freight } \\
\hline $\begin{array}{l}\text { Net Petroleum } \\
\text { Consumption Intensity }\end{array}$ & $\begin{array}{l}\text { kg crude oil/ } \\
1,000 \text { GTK }\end{array}$ & 2.5 & 2.4 & 2.3 & 2.1 & 0.49 \\
\hline $\begin{array}{l}\text { Net Petroleum } \\
\text { Displacement Intensity }\end{array}$ & $\begin{array}{l}\text { kg crude oil/ } \\
1,000 \text { GTK }\end{array}$ & - & 0.095 & 0.19 & 0.38 & 2.0 \\
\hline \multicolumn{7}{|c|}{ Rail Transport-Passenger } \\
\hline $\begin{array}{l}\text { Net Petroleum } \\
\text { Consumption Intensity }\end{array}$ & $\begin{array}{l}\text { kg crude oil/ } \\
1,000 \text { GTK }\end{array}$ & 4.1 & 4.0 & 3.8 & 3.5 & 0.81 \\
\hline $\begin{array}{l}\text { Net Petroleum } \\
\text { Displacement Intensity }\end{array}$ & $\begin{array}{l}\text { kg crude oil/ } \\
\text { 1,000 GTK }\end{array}$ & - & 0.16 & 0.32 & 0.64 & 3.3 \\
\hline \multicolumn{7}{|l|}{ Road Transport-Freight } \\
\hline $\begin{array}{l}\text { Net Petroleum } \\
\text { Consumption Intensity }\end{array}$ & $\begin{array}{l}\text { kg crude oil/ } \\
1,000 \text { GTK }\end{array}$ & 12 & 12 & 11 & 10 & 2.4 \\
\hline $\begin{array}{l}\text { Net Petroleum } \\
\text { Displacement Intensity }\end{array}$ & $\begin{array}{l}\text { kg crude oil/ } \\
1,000 \text { GTK }\end{array}$ & - & 0.46 & 0.93 & 1.9 & 9.7 \\
\hline \multicolumn{7}{|c|}{ Road Transport-Passenger } \\
\hline $\begin{array}{l}\text { Net Petroleum } \\
\text { Consumption Intensity }\end{array}$ & $\begin{array}{l}\text { kg crude oil/ } \\
1,000 \text { GTK }\end{array}$ & 16 & 15 & 15 & 14 & 3.1 \\
\hline $\begin{array}{l}\text { Net Petroleum } \\
\text { Displacement Intensity }\end{array}$ & $\begin{array}{l}\text { kg crude oil/ } \\
\text { 1,000 GTK }\end{array}$ & - & 0.61 & 1.2 & 2.5 & 13 \\
\hline \multicolumn{7}{|c|}{ Fuel Delivered to Transport Vehicles*** } \\
\hline $\begin{array}{l}\text { Net Petroleum } \\
\text { Consumption Intensity }\end{array}$ & $\begin{array}{l}\text { g crude oil/ } \\
\text { MJ fuel delivered }\end{array}$ & 27 & 26 & 25 & 23 & 5.2 \\
\hline $\begin{array}{l}\text { Net Petroleum } \\
\text { Displacement Intensity }\end{array}$ & $\begin{array}{l}\text { g crude oil/ } \\
\text { MJ fuel delivered }\end{array}$ & & 1.0 & 2.1 & 4.1 & 22 \\
\hline $\begin{array}{l}\text { Percent Change from } \\
\text { Diesel for Petroleum } \\
\text { Consumption Intensity }\end{array}$ & $\%$ & - & $-3.8 \%$ & $-7.7 \%$ & $-15 \%$ & $-80 \%$ \\
\hline $\begin{array}{l}\text { Percent Change from } \\
\text { Base Case Value for } \\
\text { Petroleum Consumption } \\
\text { Intensity*** }\end{array}$ & $\%$ & $0.0 \%$ & $0.37 \%$ & $0.79 \%$ & $1.7 \%$ & $62 \%$ \\
\hline
\end{tabular}

* The reported results assume a 20-year system lifetime with 2 billion GTK transported over that time. The study employs IPCC (2007) GWP values. Results are rounded to two significant figures as an indication of their uncertainty. ** The system boundaries for this calculation are well to pump plus carbon content of fuel.

${ }^{* * *}$ Percent change in petroleum consumption intensity from the diesel reference system and from the base case value is constant for all transport modes as it is due to variations in the wells-to-pump portion of the life cycle, assuming that the fuel economy decrement (biodiesel compared to diesel) does not vary by transport mode (Kathpal 2008, Basha et al. 2009). The percent changes reported here may not equal those achieved by calculation using the results reported above owing to independent rounding. 


\subsubsection{Sensitivity Scenario C: Good Land, High Cultivation Maintenance}

This sensitivity scenario explores a scenario where Jatropha is grown on high quality land with high inputs of fertilizer and irrigation that lead to high seed yield and oil content. Fertilizer and diesel fuel input requirements are based on Reinhardt et al.'s (2008) "best" scenario that accounts for the increased nutrient and maintenance needs associated with higher seed yields. The assumption of good soil and irrigation for all life cycle years instead of just the first three results in assumed increases in oil content ( $40 \%$ vs. $35 \%$ of the base case) and a doubling of seed yield compared to the base case from $3,750 \mathrm{~kg} / \mathrm{ha}$ to $7,500 \mathrm{~kg} / \mathrm{ha}$. Table 35 outlines the parameters adjusted in this scenario.

Table 35. Sensitivity scenario C: good land, high cultivation maintenance-parameter inputs

\begin{tabular}{|c|c|c|c|c|}
\hline $\begin{array}{l}\text { Parameter } \\
\text { Description }\end{array}$ & $\begin{array}{l}\text { Input } \\
\text { Parameter }\end{array}$ & Units & $\begin{array}{l}\text { Base Case } \\
\text { Value }\end{array}$ & $\begin{array}{l}\text { Sensitivity } \\
\text { Scenario C }\end{array}$ \\
\hline $\begin{array}{l}\text { Years of irrigation } \\
\text { required }\end{array}$ & irr_years & Years & 3 & 20 \\
\hline $\begin{array}{l}\text { Diesel fuel consumed } \\
\text { for cultivation }\end{array}$ & diesel_fuel_cul & liters/ha & 86 & 141 \\
\hline $\mathrm{N}$ fertilizer required & $\mathrm{N}$ fert_req & $\mathrm{kg} \mathrm{N} /$ ha-yr & 81 & 141 \\
\hline $\mathrm{P}_{2} \mathrm{O}_{5}$ fertilizer required & $\mathrm{P} \overline{2} \mathrm{O} 5$ fert_req & $\mathrm{kg} \mathrm{P}_{2} \mathrm{O}_{5} / \mathrm{ha}-\mathrm{yr}$ & 31 & 56 \\
\hline $\mathrm{K}_{2} \mathrm{O}$ fertilizer required & $\mathrm{K} 2 \mathrm{O}$ - fert_req & $\mathrm{kg} \mathrm{K}_{2} \mathrm{O} / \mathrm{ha}-\mathrm{yr}$ & 89 & 139 \\
\hline Seed yield reduction & seed_yield_red & $\begin{array}{l}\text { Fraction reduction in } \\
\text { seed yield }\end{array}$ & 0 & $-1^{*}$ \\
\hline $\begin{array}{l}\text { Jatropha seed oil } \\
\text { content }\end{array}$ & oil_content & Mass fraction & 0.35 & 0.40 \\
\hline
\end{tabular}

* A negative seed yield reduction equates to a fractional increase in seed yield, in this case a doubling of seed yield (or $100 \%$ increase).

The results displayed in Table 36 reveal that Jatropha biodiesel produced under this scenario reduces GHG emissions by approximately $36 \%$ compared with the base case value for an overall GHG-emission reduction compared to diesel of $82 \%$. Doubling of the seed yield more than offsets the additional GHG-emission impacts from additional fertilizer and irrigation inputs. 
Table 36. Comparison of net life cycle GHG emission intensity $\left(\mathrm{kg} \mathrm{CO}_{2} \mathrm{e} / 1,000 \mathrm{GTK}\right.$ ) for sensitivity scenario $\mathrm{C}$ for each of four transport modes evaluated in this study*

\begin{tabular}{lccccc}
\hline & Diesel & B5 & B10 & B20 & B100 \\
\cline { 2 - 6 } Rail Transport-Freight & 7.9 & 7.6 & 7.3 & 6.7 & 1.4 \\
Rail Transport-Passenger & 13 & 13 & 12 & 11 & 2.4 \\
Road Transport-Freight & 39 & 37 & 36 & 32 & 7.0 \\
Road Transport-Passenger & 51 & 49 & 47 & 43 & 9.3 \\
$\begin{array}{l}\text { Fuel Delivered to Transport Vehicles } \\
\text { (g CO }\end{array}$ e / MJ fuel delivered) $^{* *}$ & 85 & 82 & 79 & 72 & 16 \\
\hline Percent Change from Diesel $^{* * *}$ & - & $-3.9 \%$ & $-7.8 \%$ & $-16 \%$ & $-82 \%$ \\
Percent Change from Base Case Result $^{* * *}$ & $0.0 \%$ & $-0.51 \%$ & $-1.1 \%$ & $-2.3 \%$ & $-36 \%$ \\
\hline
\end{tabular}

* The reported results assume a 20-year system lifetime with 2 billion GTK transported over that time. The study employs IPCC (2007) GWP values. Results are rounded to two significant figures as an indication of their uncertainty. ** The system boundaries for this calculation are well to pump plus carbon content of fuel.

*** Percent change from the diesel reference system and from the base case result is constant for all transport modes as it is due to variations in the wells-to-pump portion of the life cycle, assuming that the fuel economy decrement (biodiesel compared to diesel) does not vary by transport mode (Kathpal 2008, Basha et al. 2009). The percent changes reported here may not equal those achieved by calculation using the results reported above owing to independent rounding.

Table 37 shows that, similar to the results for GHG emissions, the increased seed yield results in a NEV that is $24 \%$ greater than the base case value.

Table 37. Comparison of net NEV (MJ/1,000 GTK) for sensitivity scenario C for each of four transport modes evaluated in this study*

\begin{tabular}{|c|c|c|c|c|c|}
\hline & Diesel & B5 & B10 & B20 & B100 \\
\hline Rail Transport-Freight & -26 & -21 & -17 & -8.2 & 64 \\
\hline Rail Transport-Passenger & -42 & -35 & -28 & -14 & 110 \\
\hline Road Transport-Freight & -120 & -100 & -82 & -40 & 310 \\
\hline Road Transport-Passenger & -160 & -140 & -110 & -53 & 420 \\
\hline $\begin{array}{l}\text { Fuel Delivered to Transport Vehicles }{ }^{* *} \\
\text { (MJ net energy benefit / MJ fuel delivered) }\end{array}$ & -0.27 & -0.23 & -0.18 & -0.089 & 0.69 \\
\hline Percent Change from Diesel ${ }^{* \star *}$ & - & $17 \%$ & $34 \%$ & $68 \%$ & $350 \%$ \\
\hline Percent Change from Base Case Result ${ }^{* * *}$ & $0.0 \%$ & $2.7 \%$ & $6.6 \%$ & $22 \%$ & $24 \%$ \\
\hline
\end{tabular}

* The reported results assume a 20-year system lifetime with 2 billion GTK transported over that time. The study employs IPCC (2007) GWP values. Results are rounded to two significant figures as an indication of their uncertainty. ** The system boundaries for this calculation are well to pump plus carbon content of fuel.

*** Percent change from the diesel reference system and from the base case result is constant for all transport modes as it is due to variations in the wells-to-pump portion of the life cycle, assuming that the fuel economy decrement (biodiesel compared to diesel) does not vary by transport mode (Kathpal 2008, Basha et al. 2009). The percent changes reported here may not equal those achieved by calculation using the results reported above owing to independent rounding. 
Finally, Table 38 reports that Jatropha biodiesel produced under these high cultivation input/high seed yield conditions reduces petroleum consumption by $42 \%$ compared with the base case, leading to an overall petroleum consumption reduction of $93 \%$ compared with petroleum diesel.

Table 38. Comparison of net life cycle GHG emission intensity for sensitivity scenario C for each of four transport modes evaluated in this study*

\begin{tabular}{|c|c|c|c|c|c|c|}
\hline & Units & Diesel & B5 & B10 & B20 & B100 \\
\hline \multicolumn{7}{|l|}{ Rail Transport-Freight } \\
\hline $\begin{array}{l}\text { Net Petroleum } \\
\text { Consumption Intensity }\end{array}$ & $\begin{array}{l}\text { kg crude oil/ } \\
1,000 \text { GTK }\end{array}$ & 2.5 & 2.4 & 2.3 & 2.0 & 0.17 \\
\hline $\begin{array}{l}\text { Net Petroleum } \\
\text { Displacement Intensity }\end{array}$ & $\begin{array}{l}\text { kg crude oil/ } \\
1,000 \text { GTK }\end{array}$ & - & 0.11 & 0.22 & 0.44 & 2.3 \\
\hline \multicolumn{7}{|l|}{ Rail Transport-Passenger } \\
\hline $\begin{array}{l}\text { Net Petroleum } \\
\text { Consumption Intensity }\end{array}$ & $\begin{array}{l}\text { kg crude oil/ } \\
1,000 \text { GTK }\end{array}$ & 4.1 & 4.0 & 3.8 & 3.4 & 0.29 \\
\hline $\begin{array}{l}\text { Net Petroleum } \\
\text { Displacement Intensity }\end{array}$ & $\begin{array}{l}\text { kg crude oil/ } \\
1,000 \text { GTK }\end{array}$ & - & 0.18 & 0.37 & 0.74 & 3.8 \\
\hline \multicolumn{7}{|l|}{ Road Transport-Freight } \\
\hline $\begin{array}{l}\text { Net Petroleum } \\
\text { Consumption Intensity }\end{array}$ & $\begin{array}{l}\text { kg crude oil/ } \\
1,000 \mathrm{GTK}\end{array}$ & 12 & 12 & 11 & 10 & 0.84 \\
\hline $\begin{array}{l}\text { Net Petroleum } \\
\text { Displacement Intensity }\end{array}$ & $\begin{array}{l}\text { kg crude oil/ } \\
1,000 \text { GTK }\end{array}$ & - & 0.54 & 1.1 & 2.2 & 11 \\
\hline \multicolumn{7}{|l|}{ Road Transport-Passenger } \\
\hline $\begin{array}{l}\text { Net Petroleum } \\
\text { Consumption Intensity }\end{array}$ & $\begin{array}{l}\text { kg crude oil/ } \\
1,000 \text { GTK }\end{array}$ & 16 & 15 & 15 & 13 & 1.1 \\
\hline $\begin{array}{l}\text { Net Petroleum } \\
\text { Displacement Intensity }\end{array}$ & $\begin{array}{l}\text { kg crude oil/ } \\
1,000 \text { GTK }\end{array}$ & - & 0.71 & 1.4 & 2.9 & 15 \\
\hline \multicolumn{7}{|c|}{ Fuel Delivered to Transport Vehicles** } \\
\hline $\begin{array}{l}\text { Net Petroleum } \\
\text { Consumption Intensity }\end{array}$ & $\begin{array}{l}\text { g crude oil/ } \\
\text { MJ fuel delivered }\end{array}$ & 27 & 26 & 24 & 22 & 1.9 \\
\hline $\begin{array}{l}\text { Net Petroleum } \\
\text { Displacement Intensity }\end{array}$ & $\begin{array}{l}\text { g crude oil/ } \\
\text { MJ fuel delivered }\end{array}$ & & 1.2 & 2.4 & 4.8 & 25 \\
\hline $\begin{array}{l}\text { Percent Change from Diesel for } \\
\text { Petroleum Consumption } \\
\text { Intensity*** }\end{array}$ & $\%$ & - & $-4.4 \%$ & $-8.9 \%$ & $-18 \%$ & $-93 \%$ \\
\hline $\begin{array}{l}\text { Percent Change from Base Case } \\
\text { Value for Petroleum Consumption } \\
\text { Intensity }\end{array}$ & $\%$ & $0.0 \%$ & $-0.25 \%$ & $-0.53 \%$ & $-1.2 \%$ & $-42 \%$ \\
\hline
\end{tabular}

* The reported results assume a 20-year system lifetime with 2 billion GTK transported over that time. The study employs IPCC (2007) GWP values. Results are rounded to two significant figures as an indication of their uncertainty. ** The system boundaries for this calculation are well to pump plus carbon content of fuel.

${ }^{* * *}$ Percent change in petroleum consumption intensity from the diesel reference system and from the base case value is constant for all transport modes as it is due to variations in the wells-to-pump portion of the life cycle, assuming that the fuel economy decrement (biodiesel compared to diesel) does not vary by transport mode (Kathpal 2008, Basha et al. 2009). The percent changes reported here may not equal those achieved by calculation using the results reported above owing to independent rounding. 


\subsubsection{Sensitivity Scenario D: Increased Seed Catchment and Biodiesel Distribution Distances}

This sensitivity scenario tests the impacts of adjusting Jatropha feedstock and processed biodiesel transportation distances to represent a more centralized biodiesel processing and distribution infrastructure. The scenario assumes that the truck transport distance for Jatropha seeds is increased from $50 \mathrm{~km}$ for a local feedstock catchment zone in the base case to $100 \mathrm{~km}$, representing a more centralized oil extraction facility ${ }^{7}$. Similarly, the transport distance for the Jatropha biodiesel is increased from $25 \mathrm{~km}$ for distribution to local markets to $500 \mathrm{~km}$, representing distribution to larger and more distant urban centers. Table 39 outlines the parameters adjusted to create this scenario.

Table 39. Sensitivity scenario D—centralized biodiesel production-input parameters

\begin{tabular}{llcc}
\hline Parameter Description & Input Parameter & $\begin{array}{l}\text { Base Case } \\
\text { Value }\end{array}$ & $\begin{array}{l}\text { Sensitivity } \\
\text { Scenario B }\end{array}$ \\
\cline { 2 - 4 } Seed transport distance $(\mathrm{Km})$ & seed_tran_dist & 50 & 100 \\
Biodiesel transport distance $(\mathrm{Km})$ & biodiesel_dist & 25 & 500 \\
\hline
\end{tabular}

As shown in Table 40, increasing the transport distances for both Jatropha seeds and biodiesel to represent a more centralized production scenario only slightly increases life cycle GHG emissions ( $+2 \%$ ). The Jatropha biodiesel maintains a more than $70 \%$ decrease in GHG emissions when compared to petroleum diesel despite seed transport distance doubling and biodiesel transport distance increasing by a factor of 20 indicating that Jatropha feedstock and biodiesel transport distances have relatively small influences on the total GHG emissions of the Jatropha biodiesel life cycle.

\footnotetext{
${ }^{7}$ For reference, Reinhardt et al. (2008) examine a maximum transport distance of approximately $40 \mathrm{~km}$ for seed transport to the oil extraction and biodiesel production facility in India.
} 
Table 40. Comparison of net life cycle GHG emission intensity (kg $\mathrm{CO}_{2} \mathrm{e} / 1,000 \mathrm{GTK}$ ) for sensitivity scenario $D$ for each of four transport modes evaluated in this study*

\begin{tabular}{lccccc}
\hline & Diesel & B5 & B10 & B20 & B100 \\
\cline { 2 - 6 } Rail Transport-Freight & 7.9 & 7.6 & 7.4 & 6.8 & 2.3 \\
Rail Transport-Passenger & 13 & 13 & 12 & 11 & 3.8 \\
Road Transport-Freight & 39 & 37 & 36 & 33 & 11 \\
Road Transport-Passenger & 51 & 49 & 47 & 44 & 15 \\
$\begin{array}{l}\text { Fuel Delivered to Transport Vehicles } \\
\text { (g CO } \mathrm{CO}_{2} \text { / MJ fuel) }\end{array}$ & 85 & 82 & 80 & 74 & 25 \\
\hline Percent Change from Diesel $^{* * *}$ & - & $-3.4 \%$ & $-6.8 \%$ & $-14 \%$ & $-71 \%$ \\
Percent Change from Base Case Result*** $^{\text {Percen }}$ & $0.0 \%$ & $0.029 \%$ & $0.061 \%$ & $0.13 \%$ & $2.1 \%$ \\
\hline
\end{tabular}

* The reported results assume a 20-year system lifetime with 2 billion GTK transported over that time. The study employs IPCC (2007) GWP values. Results are rounded to two significant figures as an indication of their uncertainty. ** The system boundaries for this calculation are well to pump plus carbon content of fuel.

*** Percent change from the diesel reference system and from the base case result is constant for all transport modes as it is due to variations in the wells-to-pump portion of the life cycle, assuming that the fuel economy decrement (biodiesel compared to diesel) does not vary by transport mode (Kathpal 2008, Basha et al. 2009). The percent changes reported here may not equal those achieved by calculation using the results reported above owing to independent rounding.

Similarly, Table 41 reveals that changes to NEV are also minimal as diesel fuel consumed in the Jatropha life cycle transport modules represents a relatively small percentage of total life cycle energy consumption. The centralized biodiesel scenario only decreases the NEV for B100 by $1.2 \%$.

Table 41. Comparison of NEV (MJ/1,000 GTK) for sensitivity scenario D for each of four transport modes evaluated in this study*

\begin{tabular}{lccccc}
\hline & Diesel & B5 & B10 & B20 & B100 \\
\cline { 2 - 6 } Rail Transport-Freight & -26 & -22 & -18 & -11 & 51 \\
Rail Transport-Passenger & -42 & -36 & -30 & -18 & 86 \\
Road Transport-Freight & -120 & -110 & -88 & -52 & 250 \\
Road Transport-Passenger & -160 & -140 & -120 & -69 & 330 \\
Fuel Delivered to Transport Vehicles** & -0.27 & -0.24 & -0.20 & -0.12 & 0.55 \\
(MJ net energy benefit / MJ fuel delivered) & - & $14 \%$ & $29 \%$ & $58 \%$ & $300 \%$ \\
\hline Percent Change from Diesel** & $0.0 \%$ & $-0.14 \%$ & $-0.33 \%$ & $-1.1 \%$ & $-1.2 \%$ \\
\hline Percent Change from Base Case Result
\end{tabular}

* The reported results assume a 20-year system lifetime with 2 billion GTK transported over that time. The study employs IPCC (2007) GWP values. Results are rounded to two significant figures as an indication of their uncertainty. ** The system boundaries for this calculation are well to pump plus carbon content of fuel.

*** Percent change from the diesel reference system and from the base case result is constant for all transport modes as it is due to variations in the wells-to-pump portion of the life cycle, assuming that the fuel economy decrement (biodiesel compared to diesel) does not vary by transport mode (Kathpal 2008, Basha et al. 2009). The percent changes reported here may not equal those achieved by calculation using the results reported above owing to independent rounding. 
Finally, Table 42 reveals that even net petroleum consumption intensity and net petroleum displacement intensity - which are directly impacted by diesel fuel consumption in Jatropha feedstock and biodiesel truck transportation - are increased by only $2.6 \%$ compared to the base case under the increased transportation distances tested in this scenario, and Jatropha biodiesel still maintains an approximately $88 \%$ net petroleum consumption intensity reduction compared with conventional diesel.

Table 42. Comparison of net petroleum consumption and displacement intensity for sensitivity scenario $D$ for each of four transport modes evaluated in this study*

\begin{tabular}{|c|c|c|c|c|c|c|}
\hline & Units & Diesel & B5 & B10 & B20 & B100 \\
\hline \multicolumn{7}{|l|}{ Rail Transport-Freight } \\
\hline $\begin{array}{l}\text { Net Petroleum } \\
\text { Consumption Intensity }\end{array}$ & $\begin{array}{l}\text { kg crude oil/ } \\
1,000 \text { GTK }\end{array}$ & 2.5 & 2.4 & 2.3 & 2.1 & 0.31 \\
\hline $\begin{array}{l}\text { Net Petroleum } \\
\text { Displacement Intensity }\end{array}$ & $\begin{array}{l}\text { kg crude oil/ } \\
1,000 \text { GTK }\end{array}$ & - & 0.10 & 0.21 & 0.42 & 2.2 \\
\hline \multicolumn{7}{|l|}{ Rail Transport-Passenger } \\
\hline $\begin{array}{l}\text { Net Petroleum } \\
\text { Consumption Intensity }\end{array}$ & $\begin{array}{l}\text { kg crude oil/ } \\
1,000 \text { GTK }\end{array}$ & 4.1 & 4.0 & 3.8 & 3.4 & 0.51 \\
\hline $\begin{array}{l}\text { Net Petroleum } \\
\text { Displacement Intensity }\end{array}$ & $\begin{array}{l}\text { kg crude oil/ } \\
1,000 \text { GTK }\end{array}$ & - & 0.17 & 0.35 & 0.70 & 3.6 \\
\hline \multicolumn{7}{|l|}{ Road Transport-Freight } \\
\hline $\begin{array}{l}\text { Net Petroleum } \\
\text { Consumption Intensity }\end{array}$ & $\begin{array}{l}\text { kg crude oil/ } \\
1,000 \text { GTK }\end{array}$ & 12 & 12 & 11 & 10 & 1.5 \\
\hline $\begin{array}{l}\text { Net Petroleum } \\
\text { Displacement Intensity }\end{array}$ & $\begin{array}{l}\text { kg crude oil/ } \\
1,000 \text { GTK }\end{array}$ & - & 0.51 & 1.0 & 2.0 & 11 \\
\hline \multicolumn{7}{|c|}{ Road Transport-Passenger } \\
\hline $\begin{array}{l}\text { Net Petroleum } \\
\text { Consumption Intensity }\end{array}$ & $\begin{array}{l}\text { kg crude oil/ } \\
1,000 \text { GTK }\end{array}$ & 16 & 15 & 15 & 13 & 2.0 \\
\hline $\begin{array}{l}\text { Net Petroleum } \\
\text { Displacement Intensity }\end{array}$ & $\begin{array}{l}\text { kg crude oil/ } \\
1,000 \text { GTK }\end{array}$ & - & 0.67 & 1.3 & 2.7 & 14 \\
\hline \multicolumn{7}{|c|}{ Fuel Delivered to Transport Vehicles** } \\
\hline $\begin{array}{l}\text { Net Petroleum } \\
\text { Consumption Intensity }\end{array}$ & $\begin{array}{l}\text { g crude oil/ } \\
\text { MJ fuel delivered }\end{array}$ & 27 & 26 & 25 & 22 & 3.3 \\
\hline $\begin{array}{l}\text { Net Petroleum } \\
\text { Displacement Intensity }\end{array}$ & $\begin{array}{l}\text { g crude oil/ } \\
\text { MJ fuel delivered }\end{array}$ & & 1.1 & 2.2 & 4.5 & 23 \\
\hline $\begin{array}{l}\text { Percent Change from Diesel } \\
\text { for Petroleum Consumption } \\
\text { Intensity*** }\end{array}$ & $\%$ & - & $-4.2 \%$ & $-8.4 \%$ & $-17 \%$ & $-88 \%$ \\
\hline $\begin{array}{l}\text { Percent Change from Base } \\
\text { Case Value for Petroleum } \\
\text { Consumption Intensity*** }\end{array}$ & $\%$ & $0.0 \%$ & $0.016 \%$ & $0.033 \%$ & $0.072 \%$ & $2.6 \%$ \\
\hline \multicolumn{7}{|c|}{$\begin{array}{l}\text { * The reported results assume a 20-year system lifetime with } 2 \text { billion GTK transported over that time. The study } \\
\text { employs IPCC (2007) GWP values. Results are rounded to two significant figures as an indication of their uncertainty } \\
{ }^{* *} \text { The system boundaries for this calculation are well to pump plus carbon content of fuel. } \\
\text { *** Percent change in petroleum consumption intensity from the diesel reference system and from the base case } \\
\text { value is constant for all transport modes as it is due to variations in the wells-to-pump portion of the life cycle, } \\
\text { assuming that the fuel economy decrement (biodiesel compared to diesel) does not vary by transport mode (Kathpal } \\
2008 \text {, Basha et al. 2009). The percent changes reported here may not equal those achieved by calculation using the } \\
\text { results reported above owing to independent rounding. }\end{array}$} \\
\hline
\end{tabular}




\subsubsection{Sensitivity Scenario E: Biomass Offset-Heat}

This sensitivity scenario tests another aspect of scenario uncertainty. It is unclear whether the biomass collected during Jatropha cultivation and harvesting will be combusted for conversion to electricity or simply burned for process heat. The heat-offset scenario employs the ecoinvent 2.0 module for burning mixed wood chips from the forest in a $50-\mathrm{kW}$ furnace with an efficiency of $80 \%$ as the offset module (Swiss Centre for Life Cycle Inventories 2008) instead of the 25\% biomass to electricity conversion efficiency assumed in the base case analyses (U.S. Climate Change Technology Program 2005). The total amount of biomass assumed available for conversion does not change from the base case analysis. The ecoinvent 2.0 module chosen as a proxy to represent the production of process heat is based on European conditions and is unlikely to match the actual production of process heat in India. Therefore, the results of this sensitivity analysis may not represent the actual impacts of the tradeoff of using collected biomass to generate either heat or electricity. However, the conversion efficiency of biomass to process heat is expected to be greater than the conversion efficiency of biomass to electricity for the actual process used on the ground in India, suggesting these results are accurate. Table 44 and Table 45 report the GHG emission, NEV, and petroleum consumption intensity impacts of offsetting process heat instead of Indian electricity.

Table 43. Comparison of net life cycle GHG emission intensity $\left(\mathrm{kg} \mathrm{CO}_{2} \mathrm{e} / 1,000 \mathrm{GTK}\right)$ for the biomass offset heat sensitivity scenario for each of four transport modes evaluated in this study*

\begin{tabular}{lccccc}
\hline & Diesel & B5 & B10 & B20 & B100 \\
\cline { 2 - 6 } Rail Transport-Freight & 7.9 & 7.6 & 7.3 & 6.7 & 1.4 \\
Rail Transport-Passenger & 13 & 13 & 12 & 11 & 2.3 \\
Road Transport-Freight & 39 & 37 & 36 & 32 & 6.9 \\
Road Transport-Passenger & 51 & 49 & 47 & 43 & 9.1 \\
$\begin{array}{l}\text { Fuel Delivered to Transport Vehicles } \\
\text { (g CO } \mathrm{g}_{2} \mathrm{e} / \text { MJ fuel delivered) }\end{array}$ & 85 & 82 & 79 & 72 & 15 \\
\hline Percent Change from Diesel*** & - & $-3.9 \%$ & $-7.8 \%$ & $-16 \%$ & $-82 \%$ \\
Percent Change from Base Case Result*** $^{* *}$ & $0.0 \%$ & $-0.53 \%$ & $-1.1 \%$ & $-2.4 \%$ & $-37 \%$ \\
\hline
\end{tabular}

* The reported results assume a 20-year system lifetime with 2 billion GTK transported over that time. The study employs IPCC (2007) GWP values. Results are rounded to two significant figures as an indication of their uncertainty. ** The system boundaries for this calculation are well to pump plus carbon content of fuel.

*** Percent change from the diesel reference system and from the base case result is constant for all transport modes as it is due to variations in the wells-to-pump portion of the life cycle, assuming that the fuel economy decrement (biodiesel compared to diesel) does not vary by transport mode (Kathpal 2008, Basha et al. 2009). The percent changes reported here may not equal those achieved by calculation using the results reported above owing to independent rounding.

Results of this sensitivity scenario analysis reveal that Jatropha biodiesel production receives a larger net GHG-emission credit from offsetting process heat than Indian electricity. Life cycle GHG emissions are decreased by approximately $37 \%$ yielding an $82 \%$ net GHG-emission advantage over the conventional diesel processing scenario, as displayed in Table 44. This result highlights the greater life cycle NEV for Jatropha biodiesel utilizing biomass rather than electricity to offset heat. The improvement is likely due to the increased process efficiency of generating process heat instead of electricity. The NEV for Jatropha biodiesel in this scenario increases by $18 \%$ from the base case value. 
Table 44. Comparison of NEV (MJ/1,000 GTK) for the biomass offset heat sensitivity scenario for each of four transport modes evaluated in this study*

\begin{tabular}{|c|c|c|c|c|c|}
\hline & Diesel & B5 & B10 & B20 & B100 \\
\hline Rail Transport-Freight & -26 & -21 & -17 & -8.8 & 62 \\
\hline Rail Transport-Passenger & -42 & -36 & -29 & -15 & 100 \\
\hline Road Transport-Freight & -120 & -100 & -84 & -43 & 300 \\
\hline Road Transport-Passenger & -160 & -140 & -110 & -56 & 400 \\
\hline $\begin{array}{l}\text { Fuel Delivered to Transport Vehicles }{ }^{* *} \\
\text { (MJ net energy benefit / MJ fuel delivered) }\end{array}$ & -0.27 & -0.23 & -0.19 & -0.095 & 0.66 \\
\hline Percent Change from Diesel ${ }^{* * *}$ & - & $16 \%$ & $33 \%$ & $66 \%$ & $340 \%$ \\
\hline Percent Change from Base Case Resultt** & $0.0 \%$ & $2.1 \%$ & $5.1 \%$ & $17 \%$ & $18 \%$ \\
\hline
\end{tabular}

* The reported results assume a 20 -year system lifetime with 2 billion GTK transported over that time. The study employs IPCC (2007) GWP values. Results are rounded to two significant figures as an indication of their uncertainty. ** The system boundaries for this calculation are well to pump plus carbon content of fuel.

*** Percent change from the diesel reference system and from the base case result is constant for all transport modes as it is due to variations in the wells-to-pump portion of the life cycle, assuming that the fuel economy decrement (biodiesel compared to diesel) does not vary by transport mode (Kathpal 2008, Basha et al. 2009). The percent changes reported here may not equal those achieved by calculation using the results reported above owing to independent rounding.

Finally, net petroleum consumption decreases by approximately $46 \%$ as compared to the base case, as shown in Table 45. While the mix of energy sources for Indian electricity minimally uses petroleum products, the process heat furnace that is offset in this scenario is modeled as one that relies on petroleum products for its operation. Therefore, offsetting process heat production yields a greater net petroleum consumption benefit than does offset Indian grid electricity. The actual energy sources for process heat in India are unknown, so the accuracy of the results for this metric is uncertain. 
Table 45. Comparison of net petroleum consumption and displacement intensity for the biomass offset heat sensitivity scenario for each of four transport modes evaluated in this study*

\begin{tabular}{|c|c|c|c|c|c|c|}
\hline & Units & Diesel & B5 & B10 & B20 & B100 \\
\hline \multicolumn{7}{|l|}{ Rail Transport-Freight } \\
\hline $\begin{array}{l}\text { Net Petroleum } \\
\text { Consumption Intensity }\end{array}$ & $\begin{array}{l}\text { kg crude oil/ } \\
1,000 \text { GTK }\end{array}$ & 2.5 & 2.4 & 2.3 & 2.0 & 0.16 \\
\hline $\begin{array}{l}\text { Net Petroleum } \\
\text { Displacement Intensity }\end{array}$ & $\begin{array}{l}\text { kg crude oil/ } \\
1,000 \text { GTK }\end{array}$ & - & 0.11 & 0.22 & 0.45 & 2.3 \\
\hline \multicolumn{7}{|l|}{ Rail Transport-Passenger } \\
\hline $\begin{array}{l}\text { Net Petroleum } \\
\text { Consumption Intensity }\end{array}$ & $\begin{array}{l}\text { kg crude oil/ } \\
1,000 \text { GTK }\end{array}$ & 4.1 & 4.0 & 3.8 & 3.4 & 0.27 \\
\hline $\begin{array}{l}\text { Net Petroleum } \\
\text { Displacement Intensity }\end{array}$ & $\begin{array}{l}\text { kg crude oil/ } \\
\text { 1,000 GTK }\end{array}$ & - & 0.18 & 0.37 & 0.74 & 3.9 \\
\hline \multicolumn{7}{|l|}{ Road Transport-Freight } \\
\hline $\begin{array}{l}\text { Net Petroleum } \\
\text { Consumption Intensity }\end{array}$ & $\begin{array}{l}\text { kg crude oil/ } \\
1,000 \text { GTK }\end{array}$ & 12 & 12 & 11 & 10 & 0.79 \\
\hline $\begin{array}{l}\text { Net Petroleum } \\
\text { Displacement Intensity }\end{array}$ & $\begin{array}{l}\text { kg crude oil/ } \\
1,000 \text { GTK }\end{array}$ & - & 0.54 & 1.1 & 2.2 & 11 \\
\hline \multicolumn{7}{|c|}{ Road Transport-Passenger } \\
\hline $\begin{array}{l}\text { Net Petroleum } \\
\text { Consumption Intensity }\end{array}$ & $\begin{array}{l}\text { kg crude oil/ } \\
1,000 \text { GTK }\end{array}$ & 16 & 15 & 15 & 13 & 1.0 \\
\hline $\begin{array}{l}\text { Net Petroleum } \\
\text { Displacement Intensity }\end{array}$ & $\begin{array}{l}\text { kg crude oil/ } \\
1,000 \text { GTK }\end{array}$ & - & 0.71 & 1.4 & 2.9 & 15 \\
\hline \multicolumn{7}{|c|}{ Fuel Delivered to Transport Vehicles** } \\
\hline $\begin{array}{l}\text { Net Petroleum } \\
\text { Consumption Intensity }\end{array}$ & $\begin{array}{l}\text { g crude oil/ } \\
\text { MJ fuel } \\
\text { delivered }\end{array}$ & 27 & 26 & 24 & 22 & 1.7 \\
\hline $\begin{array}{l}\text { Net Petroleum } \\
\text { Displacement Intensity }\end{array}$ & $\begin{array}{l}\text { g crude oil/ } \\
\text { MJ fuel } \\
\text { delivered }\end{array}$ & & 1.2 & 2.4 & 4.8 & 25 \\
\hline $\begin{array}{l}\text { Percent Change from } \\
\text { Diesel for Petroleum } \\
\text { Consumption Intensity*** }\end{array}$ & $\%$ & - & $-4.5 \%$ & $-8.9 \%$ & $-18 \%$ & $-93 \%$ \\
\hline $\begin{array}{l}\text { Percent Change from Base } \\
\text { Case Value for Petroleum } \\
\text { Consumption Intensity*** }\end{array}$ & $\%$ & $0.0 \%$ & $-0.28 \%$ & $-0.58 \%$ & $-1.3 \%$ & $-46 \%$ \\
\hline
\end{tabular}

* The reported results assume a 20-year system lifetime with 2 billion GTK transported over that time. The study employs IPCC (2007) GWP values. Results are rounded to two significant figures as an indication of their uncertainty. ** The system boundaries for this calculation are well to pump plus carbon content of fuel.

${ }^{* * *}$ Percent change in petroleum consumption intensity from the diesel reference system and from the base case values is constant for all transport modes as it is due to variations in the wells-to-pump portion of the life cycle, assuming that the fuel economy decrement (biodiesel compared to diesel) does not vary by transport mode (Kathpal 2008, Basha et al. 2009). The percent changes reported here may not equal those achieved by calculation using the results reported above owing to independent rounding. 


\subsection{Parametric Sensitivity Analyses 7.2.1 Local Sensitivity Coefficient}

Ten parameters were selected for calculating their local sensitivity coefficients to determine the impact of changes in the magnitude of the single input parameter on the overall results of the model. Refer to Whitaker and Heath (2009) for a detailed description of how local sensitivity coefficients are calculated. The normalized local sensitivity coefficient can be interpreted as the fractional change in model output resulting from a 100\% change in model input. Local sensitivity coefficients greater than one in absolute value indicate input parameters with outsized influence on the model result; local sensitivity coefficients less than one indicate parameters that have proportionally less influence on model outcomes. Negative local sensitivity coefficients indicate that the model output and input are anti-correlated; i.e., the value of the model output decreases as the value of the model input increases. Positive local sensitivity coefficients can be interpreted in the opposite manner. As LCAs are typically linear models, the local sensitivity coefficient is expected to remain consistent throughout the likely range of input parameter values.

Analyses in Whitaker and Heath (2009) were used to help determine the parameters selected for this analysis based on their relative influence on model results. The selected parameters were:

1. Dry seed yield — seeds harvested per hectare per year

2. Biodiesel efficiency - relative fuel consumption efficiency of using biodiesel vs. diesel ${ }^{8}$

3. Seed oil content - mass of Jatropha oil per mass of Jatropha seed

4. Tree density — number of Jatropha trees per hectare (impacts yield per hectare)

5. Seed cake offset - amount of fertilizer Jatropha seedcake receives credit for offsetting

6. Fertilizer use - amount of fertilizer used to manage the plantation

7. Glycerine offset-yield of refined glycerine after biodiesel transesterification

8. Plantation electricity - operational electricity consumption for plantation management

9. $\mathrm{N}_{2} \mathrm{O}$ volatilization $-\mathrm{kg} \mathrm{N} \mathrm{N}_{2} \mathrm{O}$ released/ $\mathrm{kg} \mathrm{N}$ fertilizer applied

10. Irrigation required-liters of water per year required to irrigate the plantation.

Table 46 displays the local sensitivity coefficients for the life cycle GHG emissions resulting from all modes of transport. As expected, the coefficients are the same across modes as local sensitivity coefficients measure proportional changes in output results compared with input parameters, not absolute changes in values.

\footnotetext{
${ }^{8}$ Further discussion of this topic is available in Section 3. See the first base case assumption: Fuel economy does not decrease with increasing biodiesel blends.
} 
Table 46. Local sensitivity coefficient of selected input parameters for net life cycle GHG emissions*

\begin{tabular}{|c|c|c|c|c|c|c|}
\hline \multirow[b]{2}{*}{ Rank $^{* * *}$} & \multirow[b]{2}{*}{$\begin{array}{l}\text { Parameter } \\
\text { Tested }\end{array}$} & \multirow[b]{2}{*}{ Sensitivity Scenario Description } & \multicolumn{4}{|c|}{$\begin{array}{c}\text { Normalized Local Sensitivity Coefficient (Sij) for } \\
\text { B100 Greenhouse Gas Emissions }{ }^{* *}\end{array}$} \\
\hline & & & $\begin{array}{l}\text { Road- } \\
\text { Freight } \\
\text { Transport }\end{array}$ & $\begin{array}{l}\text { Road- } \\
\text { Passenger } \\
\text { Transport }\end{array}$ & $\begin{array}{l}\text { Rail- } \\
\text { Freight } \\
\text { Transport }\end{array}$ & $\begin{array}{l}\text { Rail- } \\
\text { Passenger } \\
\text { Transport }\end{array}$ \\
\hline 1 & $\begin{array}{l}\text { Dry Seed } \\
\text { Yield }\end{array}$ & Varies the seed yield per tree & -3.7 & -3.7 & -3.7 & -3.7 \\
\hline 2 & $\begin{array}{l}\text { Biodiesel } \\
\text { Efficiency }\end{array}$ & $\begin{array}{l}\text { Varies the efficiency of B100 vs. } \\
\text { diesel }\end{array}$ & -1.1 & -1.1 & -1.1 & -1.1 \\
\hline 3 & $\begin{array}{l}\text { Seed Oil } \\
\text { Content }\end{array}$ & Varies the oil content of the seeds & -1.0 & -1.0 & -1.0 & -1.0 \\
\hline 4 & Tree Density & $\begin{array}{l}\text { Varies the density of planted trees } \\
\text { per hectare }\end{array}$ & -0.83 & -0.83 & -0.83 & -0.83 \\
\hline 5 & $\begin{array}{l}\text { Seed Cake } \\
\text { Offset }\end{array}$ & $\begin{array}{l}\text { Varies the amount of credit for the } \\
\text { seed cake offsets }\end{array}$ & -0.69 & -0.69 & -0.69 & -0.69 \\
\hline 6 & Fertilizer Use & $\begin{array}{l}\text { Varies the amount of fertilizer used } \\
\text { on the plantation }\end{array}$ & 0.59 & 0.59 & 0.59 & 0.59 \\
\hline 7 & $\begin{array}{l}\text { Glycerine } \\
\text { Offset }\end{array}$ & $\begin{array}{l}\text { Varies the assumed credit for } \\
\text { glycerine offset }\end{array}$ & -0.42 & -0.42 & -0.42 & -0.42 \\
\hline 8 & $\begin{array}{l}\text { Plantation } \\
\text { Electricity }\end{array}$ & $\begin{array}{l}\text { Varies the amount electricity used } \\
\text { to manage the plantation }\end{array}$ & 0.27 & 0.27 & 0.27 & 0.27 \\
\hline 9 & $\begin{array}{l}\mathrm{N}_{2} \mathrm{O} \\
\text { Volatilization }\end{array}$ & $\begin{array}{l}\text { Varies the } \mathrm{N}_{2} \mathrm{O} \text { volatilization rate } \\
\text { for applied nitrogen fertilizer }\end{array}$ & 0.22 & 0.22 & 0.22 & 0.22 \\
\hline 10 & $\begin{array}{l}\text { Irrigation } \\
\text { Required }\end{array}$ & $\begin{array}{l}\text { Varies the amount of irrigation } \\
\text { water required }\end{array}$ & 0.0030 & 0.0030 & 0.0030 & 0.0030 \\
\hline
\end{tabular}

* Model results, Sij values, and sensitivity run differences are rounded to two significant figures as an indication of their uncertainty.

${ }^{* *}$ Normalized Sij represents the percent change in model output per $100 \%$ percent change in an input parameter. Greater absolute Sij values indicated greater model sensitivity to change in the specified input parameter.

*** This column ranks the absolute value of $\mathrm{B} 100 \mathrm{Sij}$ value from greatest to least.

The results displayed in Table 46 identify dry seed yield as having the greatest absolute value of $\mathrm{Sij}$ and thus having the greatest influence of any single input parameter (when considered one at a time) on model results. Seed oil content and tree density also rank in the top four. The high ranks of these three parameters suggest that increasing the amount of oil obtained from a managed hectare is critical to achieving net GHG-emission benefits as a greater return is received from the same fertilizer, energy, and water inputs. These results assume that plantation operational energy consumption, fertilizer requirements, and water do not increase as the tree density or seed yield increases. Further research is needed to validate these assumptions and to better define the Jatropha plantation processes.

The base case analysis for this study (without consideration of the potential impacts of land-use change or soil carbon sequestration) estimates a net life cycle GHG-emission reduction of 72\% from switching from conventional diesel to Jatropha biodiesel at a seed yield of 3,750 kg dry seed yield per hectare per year (1.5 kg dry seed yield per tree). After identification of seed yield as the critical sensitivity parameter, the analysis was re-run with all of the same inputs except that assumed seed yield per tree was varied to determine the break-even point at which a GHG- 
emission reduction would no longer be realized. Assuming the same cultivation inputs, maintenance, transport, and processing practices, the model predicts that no GHG-emission reduction will be realized if seed yield falls below $1,250 \mathrm{~kg}$ dry seed/ha-yr $(0.50 \mathrm{~kg}$ dry seed yield/tree-year). For context, the Planning Commission of India (2003) suggests that rain-fed, poor soils may have yields as low as $1,500 \mathrm{~kg}$ dry seed yield per hectare per year. Jongschaap et al. (2007) state that currently observed seed yields for Jatropha range from $600 \mathrm{~kg}$ dry seed to $4,100 \mathrm{~kg}$ dry seed per hectare per year. The Jongschaap et al. study also cites a realistic seed yield of less than 1,000 kg dry seed yield/ha-yr under limited water conditions of 500-600 mm of rain per year with no irrigation and a seed yield of $1,450 \mathrm{~kg}$ dry seed/ha (with a plant density of 1,667 plants/ha) for an experiment conducted on marginal lands in India. While well-correlated data sets for Jatropha seed yield do not exist, current observations of Jatropha cultivation in the literature suggest that seed yields below 1,250 kg dry seed/ha are possible if land conditions are poor or if water availability is limited. Therefore, it appears unlikely that reductions in GHG emissions from the production and use of Jatropha biodiesel are guaranteed in India, and local conditions must be considered in determining the sustainability of individual projects.

Interestingly, Table 46 shows that $\mathrm{N}_{2} \mathrm{O}$ volatilization rate and irrigation requirements, which are subject to significant expert uncertainty, are among the least influential, single parameters tested in the sensitivity analyses on GWP. Results suggest that the GHG emissions resulting from additional cultivation inputs of irrigation water and fertilizer may be more than offset by the GHG-emission reduction benefits associated with achieving higher seed yields.

The same set of sensitivity cases as tested for GHG emissions were evaluated for their affect on NEV. As for GHG emissions, seed yield and biodiesel efficiency are highlighted as critically important input parameters for determining life cycle net energy values (Table 47). With the focus on energy instead of GHG emissions, fertilizer use and glycerine offset rise in importance relative to the other parameters as they directly affect the amount of synthetic chemicals that need to be produced. As expected, $\mathrm{N}_{2} \mathrm{O}$ volatilization rate does not affect the NEV of the system. 
Table 47. Local sensitivity coefficient of selected input parameters for net energy value (NEV)*

\begin{tabular}{|c|c|c|c|c|c|c|}
\hline \multirow[b]{2}{*}{$\operatorname{Rank}^{* \star *}$} & \multirow[b]{2}{*}{$\begin{array}{l}\text { Parameter } \\
\text { Tested }\end{array}$} & \multirow{2}{*}{$\begin{array}{l}\text { Sensitivity } \\
\text { Scenario } \\
\text { Description }\end{array}$} & \multicolumn{4}{|c|}{$\begin{array}{c}\text { Normalized Local Sensitivity Coefficient (Sij) } \\
\text { for B100 Net Energy Value }\end{array}$} \\
\hline & & & $\begin{array}{l}\text { Road- } \\
\text { Freight } \\
\text { Transport }\end{array}$ & $\begin{array}{l}\text { Road- } \\
\text { Passenger } \\
\text { Transport }\end{array}$ & $\begin{array}{l}\text { Rail- } \\
\text { Freight } \\
\text { Transport }\end{array}$ & $\begin{array}{l}\text { Rail- } \\
\text { Passenger } \\
\text { Transport }\end{array}$ \\
\hline 1 & $\begin{array}{l}\text { Dry Seed } \\
\text { Yield }\end{array}$ & $\begin{array}{l}\text { Varies the seed } \\
\text { yield per tree }\end{array}$ & 2.6 & 2.6 & 2.6 & 2.6 \\
\hline 2 & $\begin{array}{l}\text { Biodiesel } \\
\text { Efficiency }\end{array}$ & $\begin{array}{l}\text { Varies the } \\
\text { efficiency of B100 } \\
\text { vs. diesel }\end{array}$ & 0.85 & 0.85 & 0.85 & 0.85 \\
\hline 3 & $\begin{array}{l}\text { Seed Oil } \\
\text { Content }\end{array}$ & $\begin{array}{l}\text { Varies the oil } \\
\text { content of the } \\
\text { seeds }\end{array}$ & 0.63 & 0.63 & 0.63 & 0.63 \\
\hline 4 & $\begin{array}{l}\text { Seed Cake } \\
\text { Offset }\end{array}$ & $\begin{array}{l}\text { Varies the amount } \\
\text { of credit for the } \\
\text { seed cake offsets }\end{array}$ & 0.51 & 0.51 & 0.51 & 0.51 \\
\hline 5 & Fertilizer Use & $\begin{array}{l}\text { Varies the amount } \\
\text { of fertilizer used } \\
\text { on the plantation }\end{array}$ & -0.44 & -0.44 & -0.44 & -0.44 \\
\hline 6 & $\begin{array}{l}\text { Glycerine } \\
\text { Offset }\end{array}$ & $\begin{array}{l}\text { Varies the } \\
\text { assumed credit } \\
\text { for glycerine offset }\end{array}$ & 0.29 & 0.29 & 0.29 & 0.29 \\
\hline 7 & Tree Density & $\begin{array}{l}\text { Varies the density } \\
\text { of planted trees } \\
\text { per hectare }\end{array}$ & 0.27 & 0.27 & 0.27 & 0.27 \\
\hline 8 & $\begin{array}{l}\text { Plantation } \\
\text { Electricity }\end{array}$ & $\begin{array}{l}\text { Varies the amount } \\
\text { electricity use to } \\
\text { manage the } \\
\text { plantation }\end{array}$ & -0.14 & -0.14 & -0.14 & -0.14 \\
\hline 9 & $\begin{array}{l}\text { Irrigation } \\
\text { Required }\end{array}$ & $\begin{array}{l}\text { Varies the amount } \\
\text { of irrigation water } \\
\text { required }\end{array}$ & -0.0022 & -0.0022 & -0.0022 & -0.0022 \\
\hline 10 & $\begin{array}{l}\mathrm{N}_{2} \mathrm{O} \\
\text { Volatilization }\end{array}$ & $\begin{array}{l}\text { Varies the } \mathrm{N}_{2} \mathrm{O} \\
\text { volatilization rate } \\
\text { for applied } \\
\text { nitrogen fertilizer }\end{array}$ & 0.00 & 0.00 & 0.00 & 0.00 \\
\hline
\end{tabular}

* Model results, Sij values, and sensitivity run differences are rounded to two significant figures as an indication of their uncertainty.

** Normalized Sij represents the percent change in model output per 100\% percent change in an input parameter. Greater absolute Sij values indicated greater model sensitivity to change in the specified input parameter.

${ }^{* * *}$ This column ranks the absolute value of B100 Sij value from greatest to least.

Table 48 reports the local sensitivity coefficients for petroleum consumption intensity and again highlights dry seed yield as the critical input parameter because it impacts numerous calculations within the model. Increased seed oil content also significantly reduces petroleum consumption intensity by improving the overall efficiency of the biodiesel production system. Biodiesel efficiency also clearly has a direct impact on petroleum consumption intensity as it influences the amount of biodiesel required to be supplied. Plantation electricity has minimal influence as the Indian electricity grid uses very little petroleum. 
Table 48. Local sensitivity coefficient of selected input parameters for net petroleum consumption intensity*

\begin{tabular}{|c|c|c|c|c|c|c|}
\hline \multirow[b]{2}{*}{ Rank $^{* * *}$} & \multirow{2}{*}{$\begin{array}{l}\text { Parameter } \\
\text { Tested }\end{array}$} & \multirow{2}{*}{$\begin{array}{l}\text { Sensitivity } \\
\text { Scenario } \\
\text { Description }\end{array}$} & \multicolumn{4}{|c|}{$\begin{array}{l}\text { Normalized Local Sensitivity Coefficient (Sij) } \\
\text { for B100 Petroleum Consumption Intensity** }\end{array}$} \\
\hline & & & $\begin{array}{l}\text { Road- } \\
\text { Freight } \\
\text { Transport }\end{array}$ & $\begin{array}{l}\text { Road- } \\
\text { Passenger } \\
\text { Transport }\end{array}$ & $\begin{array}{l}\text { Rail- } \\
\text { Freight } \\
\text { Transport }\end{array}$ & $\begin{array}{l}\text { Rail- } \\
\text { Passenger } \\
\text { Transport }\end{array}$ \\
\hline 1 & $\begin{array}{l}\text { Dry Seed } \\
\text { Yield }\end{array}$ & $\begin{array}{l}\text { Varies the seed } \\
\text { yield per tree }\end{array}$ & -4.5 & -4.5 & -4.5 & -4.5 \\
\hline 2 & $\begin{array}{l}\text { Seed Oil } \\
\text { Content }\end{array}$ & $\begin{array}{l}\text { Varies the oil } \\
\text { content of the } \\
\text { seeds }\end{array}$ & -1.4 & -1.4 & -1.4 & -1.4 \\
\hline 3 & $\begin{array}{l}\text { Biodiesel } \\
\text { Efficiency }\end{array}$ & $\begin{array}{l}\text { Varies the } \\
\text { efficiency of B100 } \\
\text { vs. diesel }\end{array}$ & -1.1 & -1.1 & -1.1 & -1.1 \\
\hline 4 & $\begin{array}{l}\text { Seed Cake } \\
\text { Offset }\end{array}$ & $\begin{array}{l}\text { Varies the amount } \\
\text { of credit for the } \\
\text { seed cake offsets }\end{array}$ & -0.52 & -0.52 & -0.52 & -0.52 \\
\hline 5 & Fertilizer Use & $\begin{array}{l}\text { Varies the amount } \\
\text { of fertilizer used } \\
\text { on the plantation }\end{array}$ & 0.50 & 0.50 & 0.50 & 0.50 \\
\hline 6 & $\begin{array}{l}\text { Glycerine } \\
\text { Offset }\end{array}$ & $\begin{array}{l}\text { Varies the } \\
\text { assumed credit } \\
\text { for glycerine } \\
\text { offset }\end{array}$ & -0.43 & -0.43 & -0.43 & -0.43 \\
\hline 7 & Tree Density & $\begin{array}{l}\text { Varies the density } \\
\text { of planted trees } \\
\text { per hectare }\end{array}$ & -0.21 & -0.21 & -0.21 & -0.21 \\
\hline 8 & $\begin{array}{l}\text { Plantation } \\
\text { Electricity }\end{array}$ & $\begin{array}{l}\text { Varies the amount } \\
\text { electricity use to } \\
\text { manage the } \\
\text { plantation }\end{array}$ & 0.020 & 0.020 & 0.020 & 0.020 \\
\hline 9 & $\begin{array}{l}\text { Irrigation } \\
\text { Required }\end{array}$ & $\begin{array}{l}\text { Varies the amount } \\
\text { of irrigation water } \\
\text { required }\end{array}$ & 0.0031 & 0.0031 & 0.0031 & 0.0031 \\
\hline 10 & $\begin{array}{l}\mathrm{N}_{2} \mathrm{O} \\
\text { Volatilization }\end{array}$ & $\begin{array}{l}\text { Varies the } \mathrm{N}_{2} \mathrm{O} \\
\text { volatilization rate } \\
\text { for applied } \\
\text { nitrogen fertilizer }\end{array}$ & 0.00 & 0.00 & 0.00 & 0.00 \\
\hline
\end{tabular}

* Model results, $S_{i j}$ values, and sensitivity run differences are rounded to two significant figures as an indication of their uncertainty.

${ }^{* *}$ Normalized $\mathrm{S}_{\mathrm{ij}}$ represents the percent change in model output per $100 \%$ percent change in an input parameter.

Greater absolute $S_{i j}$ values indicated greater model sensitivity to change in the specified input parameter.

$* * *$ This column ranks the absolute value of $B 100 \mathrm{~S}_{\mathrm{ij}}$ value from greatest to least. 


\subsubsection{Individual Parameters Alternate Values}

In addition to the five scenarios that tested the impacts of combinations of parameters and the local sensitivity coefficient analysis that compared the relative influence of a one hundred percent variation in the estimate of individual input parameters on model outputs, this study also selected two single parameters for which an alternate parameter estimate was evaluated. These two parameters were selected owing to significant expert uncertainty in the estimation of their value.

\section{$\mathrm{N}_{2} \mathrm{O}$ Volatilization Rate}

The volatilization rate of $\mathrm{N}_{2} \mathrm{O}$ from applied nitrogen fertilizer is highly uncertain and can vary by location. The relationship between $\mathrm{N}_{2} \mathrm{O}$ emissions and $\mathrm{N}$ fertilizer applied is not well-known, leading to model uncertainty. The base case uses the IPCC (2006) estimated direct emission factor of $0.01 \mathrm{~kg} \mathrm{~N} 2 \mathrm{O} / \mathrm{kg} \mathrm{N}$ fertilizer. This alternative scenario tests the potential impact of including indirect $\mathrm{N}_{2} \mathrm{O}$ emissions by using the midpoint of Crutzen et al.'s (2008) estimates for the volatilization factor, $0.04 \mathrm{~kg} \mathrm{~N}_{2} \mathrm{O} / \mathrm{kg} \mathrm{N}$ fertilizer, a quadrupling of the base case estimate. Table 49 reports the results for life cycle GHG emissions. Life cycle NEV and petroleum consumption intensity are unaffected by $\mathrm{N}_{2} \mathrm{O}$ volatilization rates.

Table 49. Comparison of net life cycle GHG emission intensity $\left(\mathrm{kg} \mathrm{CO}_{2} \mathrm{e} / 1,000 \mathrm{GTK}\right)$ for the $\mathrm{N}_{2} \mathrm{O}$ volatilization rate sensitivity scenario for each of four transport modes evaluated in this study*

\begin{tabular}{|c|c|c|c|c|c|}
\hline & Diesel & B5 & B10 & B20 & B100 \\
\hline Rail Transport-Freight & 7.9 & 7.7 & 7.5 & 7.1 & 3.7 \\
\hline Rail Transport-Passenger & 13 & 13 & 13 & 12 & 6.2 \\
\hline Road Transport-Freight & 39 & 38 & 37 & 35 & 18 \\
\hline Road Transport-Passenger & 51 & 50 & 48 & 46 & 24 \\
\hline $\begin{array}{l}\text { Fuel Delivered to Transport Vehicles } \\
\left(\mathrm{g} \mathrm{CO}_{2} \mathrm{e} / \mathrm{MJ} \text { fuel delivered) }\right.\end{array}$ & 85 & 83 & 81 & 77 & 40 \\
\hline Percent Change from Diesel $^{\star \star \star}$ & - & $-2.5 \%$ & $-5.0 \%$ & $-10 \%$ & $-53 \%$ \\
\hline Percent Change from Base Case Result*** & $0.0 \%$ & $0.92 \%$ & $1.9 \%$ & $4.2 \%$ & $66 \%$ \\
\hline
\end{tabular}

* The reported results assume a 20-year system lifetime with 2 billion GTK transported over that time. The study employs IPCC (2007) GWP values. Results are rounded to two significant figures as an indication of their uncertainty ** The system boundaries for this calculation are well to pump plus carbon content of fuel.

*** Percent change from the diesel reference system and from the base case result is constant for all transport modes as it is due to variations in the wells-to-pump portion of the life cycle, assuming that the fuel economy decrement (biodiesel compared to diesel) does not vary by transport mode (Kathpal 2008, Basha et al. 2009). The percent changes reported here may not equal those achieved by calculation using the results reported above owing to independent rounding.

The results show that quadrupling the $\mathrm{N}_{2} \mathrm{O}$ volatilization rate leads to an increase in life cycle GHG emissions for Jatropha biodiesel production of $66 \%$, thereby reducing the net GHGemission advantage compared with convention diesel from $72 \%$ in the base case to $53 \%$ in this scenario. While it is possible that $\mathrm{N}_{2} \mathrm{O}$ volatilization could be even higher than the rate tested in this scenario, it would appear that the conclusion that Jatropha biodiesel provides a life cycle GHG-emission reduction compared to diesel (without consideration of the impact of land-use change or soil carbon sequestration) is robust. 


\section{Biodiesel efficiency loss}

The base case for this study assumes there is no efficiency loss when biodiesel is used in place of conventional diesel in transport vehicles, according to results of Indian Railways studies (Kathpal 2008) and a literature survey of studies on the performance of engines used for road transport operating on biodiesel blends (Basha et al. 2009). However, Van Gerpen (2009) suggests that biodiesel efficiency loss may be as high as $8 \%$ for B100, scaling proportionally with biodiesel blends. This scenario tests the impact on results of assuming an $8 \%$ efficiency loss for the use of B100. Table 50, Table 51, and Table 52 report the model results for GHG emissions, NEV, and petroleum consumption intensity for each of the transport modes.

Table 50. Comparison of net life cycle GHG emission intensity ( $\left.\mathrm{kg} \mathrm{CO}_{2} \mathrm{e} / 1,000 \mathrm{GTK}\right)$ for the biodiesel efficiency loss sensitivity scenario for each of four transport modes evaluated in this study*

\begin{tabular}{lccccc}
\hline & Diesel & B5 & B10 & B20 & B100 \\
\cline { 2 - 6 } Rail Transport-Freight & 7.9 & 7.7 & 7.4 & 6.9 & 2.5 \\
Rail Transport-Passenger & 13 & 13 & 12 & 12 & 4.1 \\
Road Transport-Freight & 39 & 37 & 36 & 34 & 12 \\
Road Transport-Passenger $^{*}$ & 51 & 49 & 48 & 45 & 16 \\
\hline Percent Change from Diesel $^{* *}$ & $0.0 \%$ & $-3.0 \%$ & $-6.1 \%$ & $-12 \%$ & $-69 \%$ \\
Percent Change from Base Case Result** $^{*}$ & $0.0 \%$ & $0.40 \%$ & $0.81 \%$ & $1.6 \%$ & $8.7 \%$ \\
\hline
\end{tabular}

* The reported results assume a 20-year system lifetime with 2 billion GTK transported over that time. The study employs IPCC (2007) GWP values. Results are rounded to two significant figures as an indication of their uncertainty. ** Percent change from the diesel reference system and from the base case result is constant for all transport modes as it is due to variations in the wells-to-pump portion of the life cycle, assuming that the fuel economy decrement (biodiesel compared to diesel) does not vary by transport mode (Kathpal 2008, Basha et al. 2009). The percent changes reported here may not equal those achieved by calculation using the results reported above owing to independent rounding.

Table 50 shows that although net GHG emissions are greater for each of the transport modes compared with the base case scenario, the use of B100 still maintains an approximately $69 \%$ GHG-emission advantage compared with conventional diesel. Net GHG emissions increase for each transport mode for the B100 scenario by approximately $8.7 \%$ from the base case because of the assumed efficiency drop of operating the vehicles on Jatropha biodiesel, leading to increases in fuel consumption. End-use efficiency leverages all upstream processes such that there is an approximately proportional increase in GHG emissions that results from a fuel efficiency decrease.

Table 51 shows that despite the loss in efficiency in this scenario, B100 still maintains a positive net energy value for all modes of transport, losing only $6.8 \%$ in NEV compared with the base case. 
Table 51. Comparison of NEV (MJ/1,000 GTK) for the biodiesel efficiency loss sensitivity scenario for each

of four transport modes evaluated in this study*

\begin{tabular}{lccccc}
\hline & Diesel & B5 & B10 & B20 & B100 \\
\cline { 2 - 5 } Rail Transport-Freight & -26 & -22 & -19 & -12 & 49 \\
Rail Transport-Passenger & -42 & -37 & -32 & -20 & 81 \\
Road Transport-Freight & -120 & -110 & -93 & -60 & 240 \\
Road Transport-Passenger & -160 & -140 & -120 & -79 & 310 \\
\hline Percent Change from Diesel** $_{\text {Percent Change from Base Case Result** }}^{*}$ & $0.0 \%$ & $-13 \%$ & $-26 \%$ & $-52 \%$ & $-290 \%$ \\
P $^{* *}$ & $0.0 \%$ & $-2.1 \%$ & $-4.9 \%$ & $-16 \%$ & $-6.8 \%$ \\
\hline
\end{tabular}

* The reported results assume a 20-year system lifetime with 2 billion GTK transported over that time. The study employs IPCC (2007) GWP values. Results are rounded to two significant figures as an indication of their uncertainty. ** Percent change from the diesel reference system and from base case result is constant for all transport modes as it is due to variations in the wells-to-pump portion of the life cycle, assuming that the fuel economy decrement (biodiesel compared to diesel) does not vary by transport mode (Kathpal 2008, Basha et al. 2009). The percent changes reported here may not equal those achieved by calculation using the results reported above owing to independent rounding.

Finally, as expected, petroleum consumption intensity also increases because of the increased demand for fuel created by the drop in fuel consumption efficiency in this scenario (Table 52). Base case values increase by approximately $8.7 \%$ for B100 but Jatropha biodiesel production and use still reduces petroleum consumption by $87 \%$ compared with conventional diesel. 
Table 52. Comparison of net petroleum consumption and displacement intensity for the biodiesel efficiency loss sensitivity scenario for each of four transport modes evaluated in this study*

\begin{tabular}{|c|c|c|c|c|c|c|}
\hline & Units & Diesel & B5 & B10 & B20 & B100 \\
\hline \multicolumn{7}{|l|}{ Rail Transport-Freight } \\
\hline $\begin{array}{l}\text { Net Petroleum } \\
\text { Consumption Intensity }\end{array}$ & $\begin{array}{l}\text { kg crude oil/ } \\
1,000 \text { GTK }\end{array}$ & 2.5 & 2.4 & 2.3 & 2.1 & 0.32 \\
\hline $\begin{array}{l}\text { Net Petroleum } \\
\text { Displacement Intensity }\end{array}$ & $\begin{array}{l}\text { kg crude oil/ } \\
1,000 \text { GTK }\end{array}$ & - & 0.095 & 0.19 & 0.39 & 2.2 \\
\hline \multicolumn{7}{|l|}{ Rail Transport-Passenger } \\
\hline $\begin{array}{l}\text { Net Petroleum } \\
\text { Consumption Intensity }\end{array}$ & $\begin{array}{l}\text { kg crude oil/ } \\
1,000 \text { GTK }\end{array}$ & 4.1 & 4.0 & 3.8 & 3.5 & 0.54 \\
\hline $\begin{array}{l}\text { Net Petroleum } \\
\text { Displacement Intensity }\end{array}$ & $\begin{array}{l}\text { kg crude oil/ } \\
1,000 \text { GTK }\end{array}$ & - & 0.16 & 0.32 & 0.64 & 3.6 \\
\hline \multicolumn{7}{|l|}{ Road Transport-Freight } \\
\hline $\begin{array}{l}\text { Net Petroleum } \\
\text { Consumption Intensity }\end{array}$ & $\begin{array}{l}\text { kg crude oil/ } \\
1,000 \text { GTK }\end{array}$ & 12 & 12 & 11 & 10 & 1.6 \\
\hline $\begin{array}{l}\text { Net Petroleum } \\
\text { Displacement Intensity }\end{array}$ & $\begin{array}{l}\text { kg crude oil/ } \\
1,000 \text { GTK }\end{array}$ & - & 0.46 & 0.93 & 1.9 & 11 \\
\hline \multicolumn{7}{|l|}{ Road Transport-Passenger } \\
\hline $\begin{array}{l}\text { Net Petroleum } \\
\text { Consumption Intensity }\end{array}$ & $\begin{array}{l}\text { kg crude oil/ } \\
1,000 \text { GTK }\end{array}$ & 16 & 15 & 15 & 13 & 2.1 \\
\hline $\begin{array}{l}\text { Net Petroleum } \\
\text { Displacement Intensity }\end{array}$ & $\begin{array}{l}\text { kg crude oil/ } \\
1,000 \text { GTK }\end{array}$ & - & 0.61 & 1.2 & 2.5 & 14 \\
\hline Percent Change from Diesel $^{* \star}$ & $\%$ & $0.0 \%$ & $-3.8 \%$ & $-7.7 \%$ & $-16 \%$ & $-87 \%$ \\
\hline Percent Change from Base Case Result** & $\%$ & $0.0 \%$ & $0.40 \%$ & $0.81 \%$ & $1.6 \%$ & $8.7 \%$ \\
\hline
\end{tabular}




\subsection{Interpretation and Comparison of Sensitivity Analyses 7.3.1 Parametric Sensitivity Analysis Results}

As many of the model's input parameters are uncertain, the sensitivity analyses are useful in focusing future research on the parameters most likely to impact study results and policy decisions. The parametric sensitivity analysis of this study indicates that dry seed yield, biodiesel efficiency, and seed oil content are the most influential individual parameters. Dry seed yield and seed oil content both directly determine the amount of Jatropha oil that can be extracted from one hectare of land, and thus are functions of not only land quality and location but also of human inputs such as fertilizer and irrigation water. As the seed yield and oil content improve through optimal cultivation, inputs of fertilizer and irrigation water per liter of Jatropha oil extracted from an area of cultivated land decrease, leading to lower life cycle impacts. Unfortunately, the literature does not contain well-correlated sets of data that accurately predict dry seed yield and seed oil content given a set of agro-climatic conditions and a selected tree density. Further research is needed in this area to improve the predictive quality of models that evaluate the impacts of Jatropha cultivation. However, the sensitivity analyses of this study suggest that the use of irrigation water and fertilizer do not preclude obtaining net GHG emission and petroleum consumption benefits if they more than commensurately increase seed yield and oil content thus offsetting the impacts of the additional inputs.

The parameter "biodiesel efficiency" models whether there is a fuel consumption penalty related to utilizing increasing blends of biodiesel in transport vehicles. While Indian railways studies (Kathpal 2008) have indicated no penalty for blends up to B20 for rail transport and the literature review by Basha et al. (2009) suggest similar results for road transport, Van Gerpen (2009) suggests a penalty of up to $8 \%$ with B100 (1.6\% for B20). Nevertheless, even if an $8 \%$ efficiency loss is assumed, Jatropha biodiesel still realizes significant, though slightly tempered, GHGemission and petroleum consumption savings along with positive NEVs assuming the remainder of the base case analysis conditions remain constant (Table 50, Table 51, and Table 52).

\subsubsection{Rose Plots of Scenario Sensitivity Results}

An important function of the sensitivity scenario analyses is to determine the impact on projected reductions under alternative plausible biodiesel production scenarios that are more or less optimized than the base case scenario. Figure 16, Figure 17, Figure 18, and Figure 19 display the results of all sensitivity scenario analyses in rose plots for each of the evaluated metrics. Each spur of the plots represents a distinct sensitivity scenario: scenarios A through $\mathrm{E}$, along with single parameter sensitivity scenarios focusing on $\mathrm{N}_{2} \mathrm{O}$ volatilization and biodiesel efficiency loss. Results are plotted as a ratio of the sensitivity scenario result compared to the base case result, where a result greater than 1 indicates an increase in that metric, while values less than 1 indicate reductions in that metric. These plots can be used to quickly determine whether the analyzed sensitivity scenarios are having a beneficial or negative impact on the study's results compared with the base case scenario. 


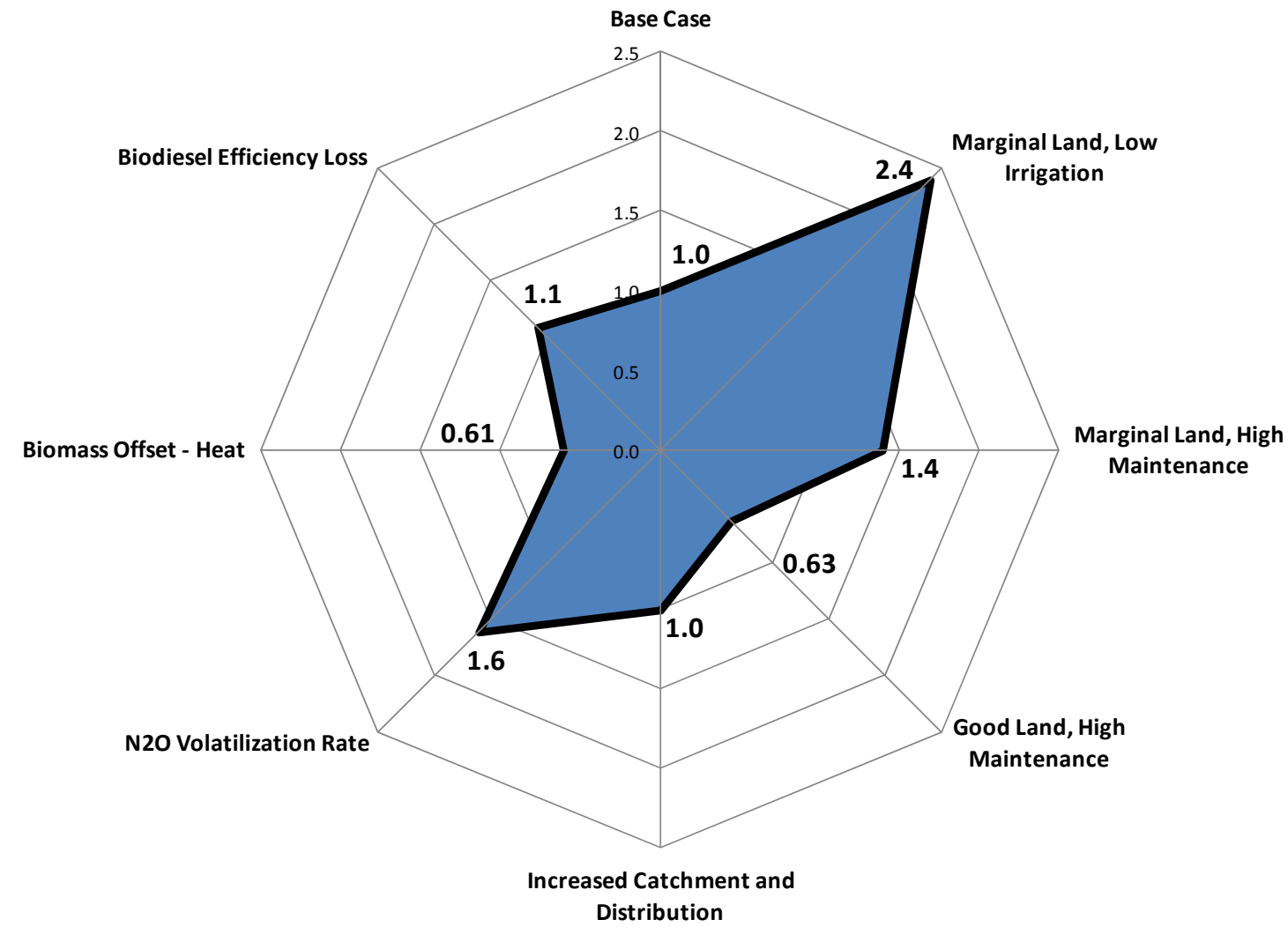

Figure 16. Result of sensitivity analysis on B100 net life cycle GHG emission intensity, as multiple of base case value

Figure 16 displays the rose plot for net life cycle GHG emissions for B100 for the base case and for all sensitivity scenarios. Five of the seven sensitivity analyses increase GHG emissions suggesting that the base case GHG-emission reductions may be near the upper end of the plausible range. Only two scenarios lead to additional GHG-emission savings. In the "Good Land, High Maintenance" scenario, the combination of fertile land and intensive cultivation practices lead to increased yields that more than offset the impacts of increased inputs. In the "Biomass Offset-Heat" scenario, biomass collected from the field is assumed to be used for local thermal energy as opposed to being used to generate electricity. The combination of these results suggests that while the magnitude of reductions under base case conditions may be somewhat optimistic, the prediction that Jatropha biodiesel offers reductions in GHG emissions compared to petroleum diesel appears robust. 


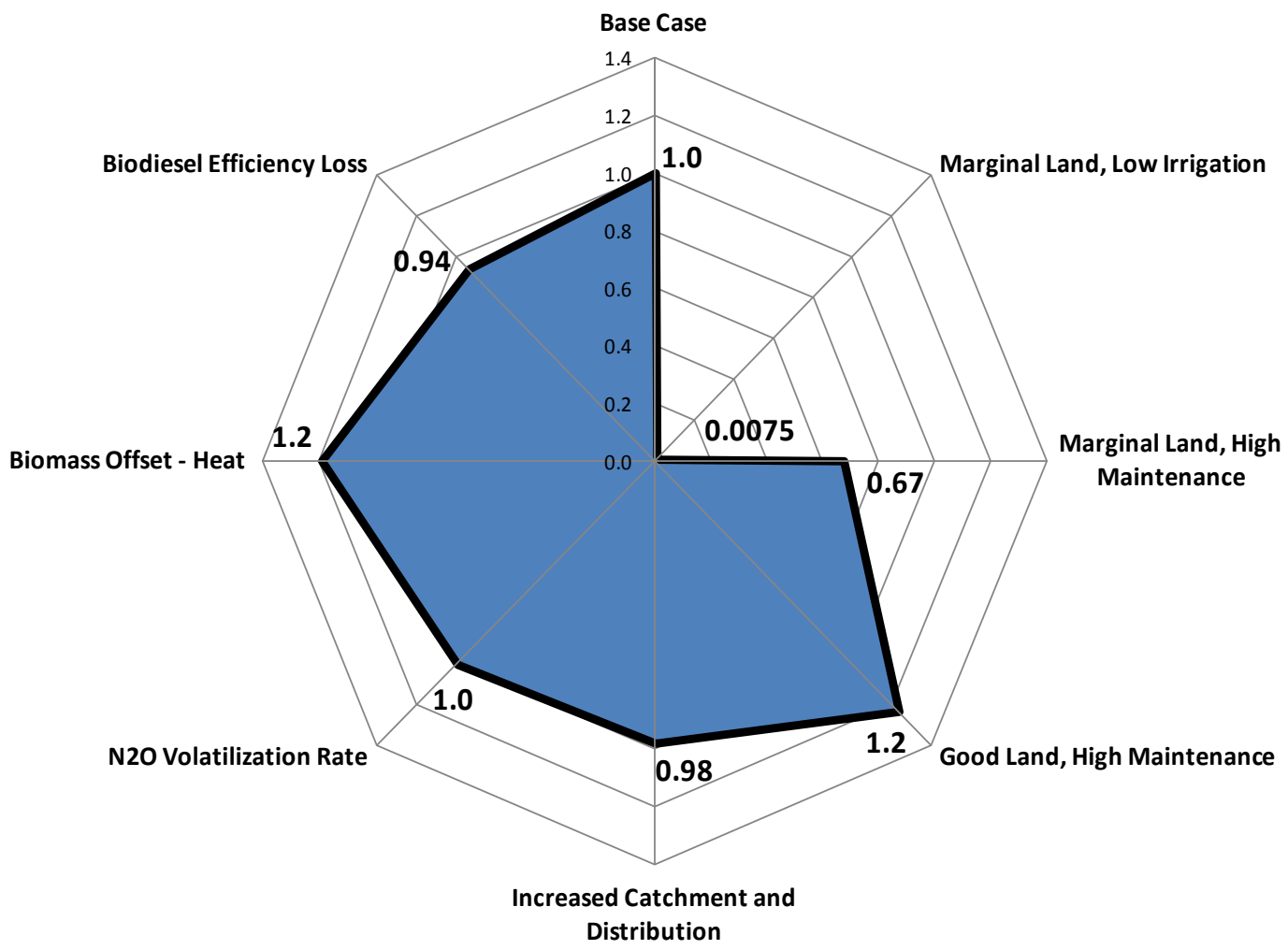

Figure 17. Result of sensitivity analysis on B100 net energy value, as multiple of base case value

Figure 17 displays the NEV for B100 under all of the sensitivity scenarios. Three of the seven scenarios result in small reductions in NEV ranging from $2 \%$ to $30 \%$. As with GHG emissions, the scenarios yielding more beneficial results are the "Good Land, High Maintenance" and "Biomass Offset-Heat scenario." $\mathrm{N}_{2} \mathrm{O}$ volatization rate has no impact on $\mathrm{NEV}$. The "Marginal Land, Low Irrigation" scenario has by far the greatest negative impact on NEV reducing the NEV for B100 by $99 \%$. However, even in that case, the NEV remains positive for B100 compared with a negative NEV for conventional petroleum diesel. Therefore, while the NEV of biodiesel may be significantly reduced by a drop in seed yield, it appears likely that Jatropha biodiesel production and processing will maintain a positive NEV. 


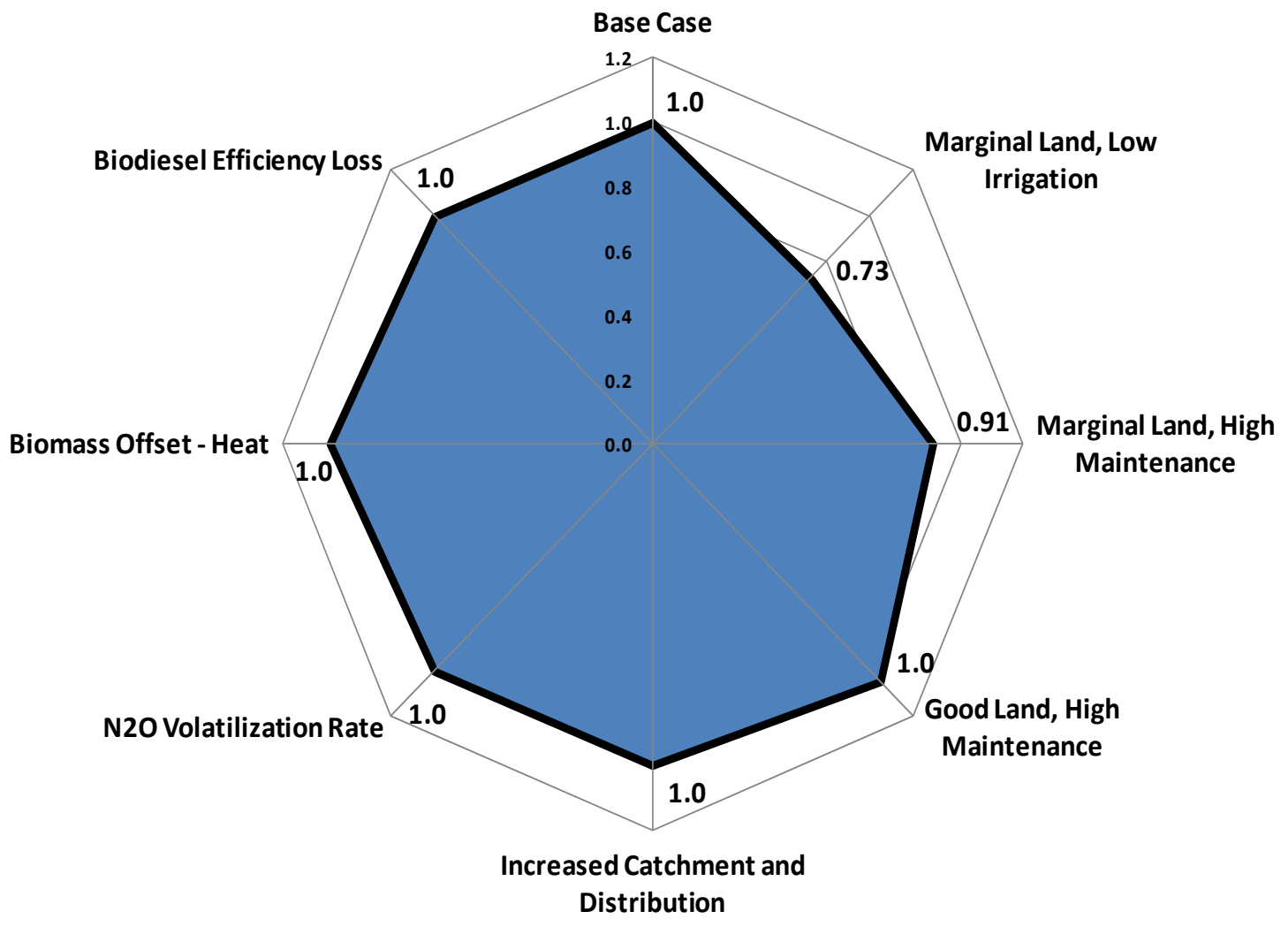

Figure 18. Result of sensitivity analysis on B100 net life cycle petroleum displacement intensity, as multiple of base case value

Figure 18 displays the results of net life cycle petroleum displacement intensity, while Figure 19 shows the correlated results for net life cycle petroleum consumption. As shown in Figure 18 the results for net petroleum displacement are relatively robust varying from being approximately equivalent to the base case value to a reduction of $27 \%$. In contrast, the net petroleum consumption values vary by a greater range of 0.53 to 2.8 times the base case value. The greater variations for petroleum consumption compared with the variations for petroleum displacement are the result of the base case value for B100 petroleum consumption being significantly smaller than the base case value for B100 petroleum displacement, thereby magnifying the relative impact of small changes in the values for the sensitivity analysis scenarios. As with GHG emissions and NEV, the "Marginal Land, Low Irrigation" scenario results in the biggest detriment to the petroleum consumption and displacement indicators. However, even the most pessimistic scenario evaluated in this study ("Marginal Land, Low Irrigation") still results in petroleum consumption reductions of $66 \%$ compared with conventional diesel strongly supporting projections of significant crude oil savings from replacing conventional diesel with Jatropha biodiesel. 


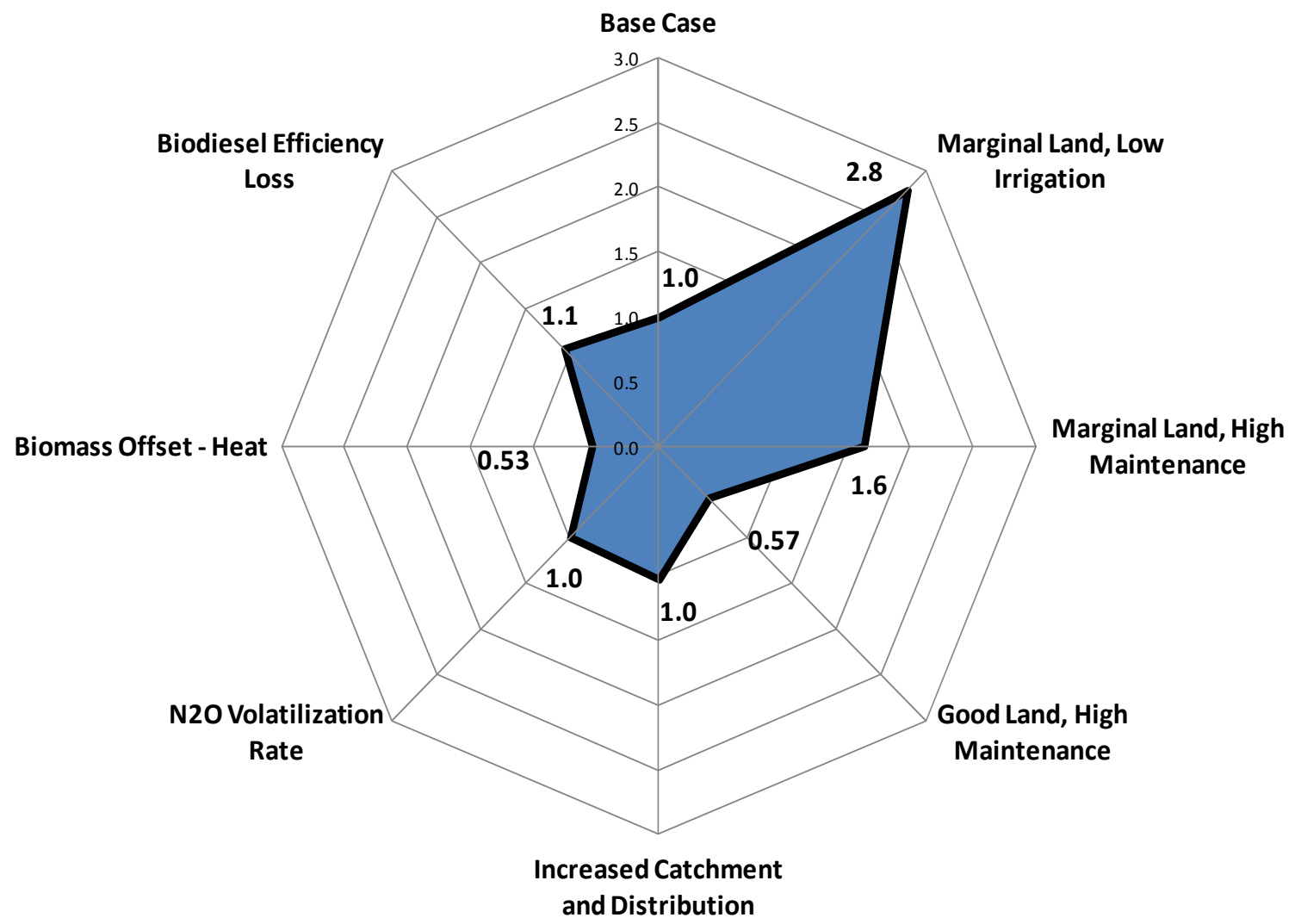

Figure 19. Result of sensitivity analysis on B100 net life cycle petroleum consumption intensity, as multiple of base case value 


\section{Discussion}

This section reviews several aspects of this study that are critical to be aware of when interpreting its results. This study has significant limitations that constrain the generalizability and certainty of its findings.

\subsection{Limitations of this Study}

As discussed in the original study, Whitaker and Heath (2009), the analysis of Jatropha biodiesel faces several limitations that constrain the interpretation and certainty of the results presented in this report. The discussion of limitations from Whitaker and Heath (2009) is repeated and expanded upon in this section. Categories of limitations include technological scope, modeling approach, data availability, economics and markets, metrics evaluated, and state of the science. Each category of limitation is discussed in further detail in the following subsections, followed by a discussion of the generalizability of the conclusions of this study.

\section{Technological Scope}

1. The scope of this study is limited in terms of the technologies evaluated. Upon the advice of the IOC, this study focused on large-scale methods of Jatropha cultivation and biodiesel production technologies. This study did not evaluate alternative methods and technologies, and thus its results should not be considered reflective of the impacts or benefits of alternative systems.

2. Jatropha as a feedstock for production of biodiesel was the focus of this study. The results of this study are not applicable to biodiesel production systems using other feedstocks nor to other biofuels as cultivation and processing requirements can vary greatly amongst biofuels and feedstocks.

\section{Modeling Approach}

1. This study is prospective in that it attempts to evaluate biodiesel production systems as they would be built in the near future in India. It is not based on data collected from an already established system. Consequently, it is unclear how well the narrative evaluated actually describes systems as they will be built.

2. This analysis was conducted using the best available published, secondary data. Data were selected for quality and applicability to IOC-recommended Jatropha biodiesel systems in the Chhattisgarh region in India. However, as these data were collected from many disparate sources most of which were not describing systems exactly like the base case, their applicability to the study region and technology was not perfect and not entirely internally consistent either. Therefore, results of this study will likely differ from the true impacts of real systems.

\section{Data Availability and Certainty}

1. India has not yet developed a comprehensive LCI database covering the production of basic materials, energy and fuels, transportation, and the ultimate disposal of goods based on India-specific conditions. As a result, many life cycle stages required inputs from better-established European databases, particularly to obtain infrastructure impacts. A key limitation of this study is that the authors were required to use non India-specific data to represent Indian processes where data were lacking. Specific examples of substituting non-Indian data included truck transport, ocean tanker transport, and crude oil extraction. 
This study improved upon Whitaker and Heath (2009) by customizing the European diesel-refining module with specific electricity and thermal energy consumption values for VIZAG, the selected Indian refinery. It is unclear how relevant the non-Indian data are to Indian processes and how much of an influence on the final results the use of Indian-specific data throughout the study would have.

2. Limited data were available for India-specific waste generation and end-of-life scenarios for both the biodiesel and diesel pathways. Facing this limitation, this study omitted impacts associated with the ultimate disposal of process waste. Inclusion of these impacts would likely not affect the conclusions of this study as additional GHG emissions, petroleum use, or energy demand for waste disposal in India are likely very small relative to the processes already included.

3. Site-specific data were unavailable for assessing potential GHG-emission impacts from direct land-use change. Conversion of the Planning Commission-identified lands to Jatropha production could result in greater, equal, or lesser soil carbon sequestration depending on the previous level of vegetation of the sites (Reinhardt et al. 2008). However, in the absence of strictly enforced regulations preventing the use of currently cultivated lands for Jatropha plantations, the better economics of higher yields could induce some conversion of prime agricultural land to Jatropha plantations. Reinhardt et al. (2008) estimated maximum potential GHG emissions from direct land-use change of approximately 73 tonnes of $\mathrm{CO}_{2}$ released per hectare if medium vegetated land is cleared to prepare land for cultivation with Jatropha plants based on an assumed net difference in carbon content of the vegetation pre- and post-cultivation of 20 tonnes carbon $/ \mathrm{ha}$. If Reinhardt et al.'s (2008) direct land-use change assumptions are applied to the base case analysis scenario conditions analyzed in our current study, the maximum direct land-use change GHG emissions would equate to approximately the following percentages of total 20-year net life cycle GHG emissions for the analyzed transport modes: $0.25 \%$ for passenger-road transport, $0.33 \%$ for freight-road transport, $1.0 \%$ for passenger-rail transport, and $1.6 \%$ for freight-rail transport. Therefore, the conclusions of the current study would not likely change significantly if the impacts of direct land-use change were included.

\section{Economics and Markets}

1. Economic analyses were not conducted to evaluate the feasibility of full market penetration of Jatropha biodiesel as B20 or of the economic viability of cultivating Jatropha only on marginal lands. As demand for Jatropha biodiesel increases, the higher yields and lower required inputs for cultivation on better land could potentially lead to prime agricultural land being converted to Jatropha plantations despite the projection of the Planning Commission of India that Jatropha development will occur on marginal lands. Conversion of prime agricultural lands to Jatropha plantations could result in indirect land use change impacts that would need to be evaluated. However, as shown in the sensitivity analyses, the increase in GHG benefits under the "good land, high maintenance" scenario would partially offset GHG impacts from indirect land use change. Trade-offs between using good land and indirect land use change were not examined in this study. 
2. This study does not perform an analysis of the potential market for glycerine co-product as biodiesel production increases. The results of this study assume that glycerine is fully utilized as a co-product and that it offsets the production of synthetic glycerine. If glycerine co-product benefits are omitted, the analyzed sustainability and energy security benefits of Jatropha biodiesel production and use are diminished, but the conclusions of the study do not change. For example, omitting glycerine co-product benefits from the base case analysis scenario decreases the GHG emission benefits of B100 compared with the petroleum diesel reference case from a $72 \%$ reduction to a $60 \%$ reduction.

\section{Metrics Evaluated}

The full extent of the sustainability and energy security impacts of switching from conventional diesel to Jatropha biodiesel is not fully represented by the metrics evaluated in this study. Other impacts such as hazardous waste generated, pollutant emissions to air, water, and soil, land-use changes, water consumption, and socio-economic impacts like gender equity are also important considerations in a full impact assessment. However, adequate data were not available to include an analysis of these metrics in this study.

\section{State of the Science}

Biodiesel cultivation and production systems in India are still immature. This study represents the current state of knowledge and data availability. Changes to the systems and improvements in the quality and quantity of data available are expected as the technologies and procedures mature. Thus, a reassessment using new data as they become available may alter the findings of this study.

\subsubsection{Generalizability of Results}

The previous section discussed limitations to the interpretation of the results of this study based on the conditions analyzed and data available. However, there are reasons to believe that the results of this study might be indicative to how other systems would perform. For instance, while this study was designed to address Indian-specific conditions, the results may be generalizable to other locations because much of the input data either originated from studies of other regions (e.g., use of ecoinvent data sets describing European systems) or are based on parameters whose values were not made site-specific (e.g., $\mathrm{N}_{2} \mathrm{O}$ volatilization rate). Furthermore, some parameter values reflect the crude state of the science more than they do a detailed reflection of siteappropriate values, e.g., fertilization rates. The sensitivity analyses, particularly the local sensitivity coefficients, are designed to allow researchers to evaluate net GHG-emission and petroleum consumption benefits given alternate scenarios that are due to changes in geographic location or agro-climatic conditions.

\subsection{Uncertainty Analysis}

Data limitations prevented a quantitative estimation of uncertainty. Many important parameters have not been studied in sufficient detail to enable proper characterization of variability and uncertainty, to identify causal relationships between parameters, and, in some cases, to even establish plausible value ranges for the parameters under a given scenario. However, several steps were taken in an effort to improve upon the uncertainty analysis in Whitaker and Heath (2009). These steps included analyzing five internally consistent sensitivity scenarios (scenarios A-E) in addition to analyzing the local sensitivity of model results to parameters tested one at a time, and to adding an extended benchmarking analysis to compare the results to other studies 
conducted both in India and in other regions of the world. This study does not calculate the best and worst case scenarios as Whitaker and Heath (2009) did because the best/worst scenarios were not internally consistent and were deemed to add limited value to the analysis as they only provide estimates of extreme boundary conditions that are not expected to occur.

\subsection{Projections of Absolute Petroleum Displaced and Net GHG Emission Reductions by Utilization of Jatropha Biodiesel in the Indian Road and Rail Sectors}

To provide context for the results of this study, the magnitude of potential absolute petroleum consumption and GHG-emission reductions from the complete substitution of B20 blends of Jatropha biodiesel for petroleum diesel in all four transportation sectors of India is analyzed. Current diesel demand (using year 2006 data as the latest available) is considered in making comparisons of relative magnitudes of potential reductions in the near term. Projections to the year 2020 are then used to analyze whether the relative magnitudes of potential reductions change when considering projections of Indian road and rail transport by sector.

\subsubsection{Calculation Method}

Results for projected reductions in petroleum consumption and GHG emissions for current conditions and 2020 are presented in Table 53 and Table 54. Projections for petroleum displacement in Table 53 are calculated based on the anticipated petroleum displacement per 1,000 GTK for B20 for the base case scenario (as presented in Table 17). Similarly, GHGemission reductions in Table 54 are calculated based on the anticipated GHG-emission reductions per 1,000 GTK for B20 for the base case scenario (as presented in Table 15). The calculations for petroleum displacement and GHG-emission reductions are scaled according to estimated total GTK in each of the four analyzed transportation sectors for current conditions and 2020. The following sources and method were used to obtain estimates of GTK for current conditions (represented by year 2006 data) and 2020:

1. Rail transport — freight: GTK for diesel freight-rail transport for the year 2006 (320 billion GTK) is reported on page 153 of the Indian Railways 2007-2008 Annual Statistical Statements (Ministry of Railways 2008). The Planning Commission projects that total freight transport (rail and road) will grow to 5,500 billion GTK by 2020 and that rail-freight transport will have a $20 \%$ mode share (1,100 billion GTK) (Planning Commission 2007).

2. Rail transport-passenger: GTK for passenger-rail transport for the year 2006 (230 billion GTK) is also reported by the Ministry of Railways (2008). However, the Planning Commission did not project passenger-rail GTK to 2020, so projections from Singh (2008) and average data from the Ministry of Railways (2008) are used to calculate estimated GTK. Singh (2008) estimates that total 2020 passenger transport (rail and road) in India will be approximately 13,000 billion pkm with a mode share of $8.3 \%$ for trains $\left(1,100\right.$ billion pkm) (Singh 2008). Assuming that the $3.8 \%$ share $^{9}$ of train passengerkilometers in 2006 that was supplied by diesel trains (Ministry of Railways 2008) applies to 2020 , passenger transport on diesel trains in 2020 will be approximately 42 billion

\footnotetext{
${ }^{9}$ Over $95 \%$ of Indian passenger train transport on a pkm basis takes place on electric, multiple unit, suburban trains as opposed to diesel trains (Ministry of Railways 2008)
} 
$\mathrm{pkm}$. Using an average passenger loading of $0.1 \mathrm{pkm} / \mathrm{GTK}^{10}$ for diesel passenger-rail transport yields a projection for 2020 diesel passenger-rail transport in India of 420 billion GTK.

3. Road transport - freight: Estimated GTK for freight-road transport in 2006 is based on data in Table No. 1.10 of India's Road Transport Yearbook for 2006-2007 (Ministry of Shipping, Road Transport, and Highways 2009). Estimated road-freight transport for 2020 (4,400 billion GTK) is calculated based on the Planning Commission's projections of 5,500 billion GTK of total freight transport in 2020 with an $80 \%$ modal share for roadfreight transport (Planning Commission 2007).

4. Road transport-passenger: GTK for passenger-road transport via buses was estimated using data from multiple sources. Singh (2008) estimates 5,555 billion pkm of passenger transport in 2006 with a $60.7 \%$ modal split for buses. Singh (2005) estimates an average loading factor for Indian buses of $40 \mathrm{pkm} / \mathrm{vkm}$. Whitaker (2007) estimates an average Indian passenger bus gross weight of 15 tonnes leading to a conversion factor of 15 GTK/vkm. Estimated GTK for 2020 is based on projections by Singh (2008) of a 43.6\% modal split for buses out of the approximately 13,000 billion pkm of passenger transport predicted for 2020. Bus weights and passenger loading factors are assumed to be the same as in 2006.

\subsubsection{Petroleum Displacement}

In 2006, India consumed approximately 145 million tonnes of crude oil with over $75 \%$ imported (International Energy Agency 2009). The transport sector accounted for approximately 25\% ( 36 million tonnes) of this consumption. According to India's Ministry of Railways (2008), in 20052006, Indian Railways operations accounted for approximately 230 billion GTK of passenger transport and 320 billion GTK of freight transport. Using the base case petroleum displacement results from Table 17, offsetting conventional diesel consumption with B20 would have saved about 160,000 tonnes of crude oil per year for rail passenger transport and 130,000 tonnes of crude oil per year for rail-freight transport in 2006 (Table 53). In the road sector in 2005-2006, goods carrying vehicles moved approximately 660 billion GTK of freight (Ministry of Shipping, Road Transport, and Highways 2009) and buses (with passengers) moved approximately 1,300 billion GTK. Replacing conventional diesel with B20 could have saved 1.4 million tonnes of crude oil in the road-freight sector and 3.5 million tonnes of crude oil in the passenger bus transport sector in 2006 (Table 53). The combined savings for the road and rail sectors using a blend of $20 \%$ Jatropha-based biodiesel and $80 \%$ conventional diesel could have been as high as 5.2 million tonnes of crude oil per year or $14 \%$ of annual transport sector crude oil consumption (3.5\% of total annual Indian crude oil consumption $)^{11}$. By 2020 , the total petroleum displacement from substituting B20 for conventional diesel in the four transport modes analyzed in this study is estimated at approximately 15 million tonnes of crude oil per year.

\footnotetext{
${ }^{10}$ Calculated from 2006 passenger-rail transport data in the Indian Railways 2007-2008 Annual Statistical Statements (Ministry of Railways 2008)

${ }^{11}$ These statistics are meant to illustrate the theoretical maximum and not to show what could be plausibly achieved in the short term given available land and other constraints. Results are based on LCA of Jatropha biodiesel only, not other feedstocks.
} 
Table 53. Projected petroleum displacement for complete substitution of Jatropha B20 produced under base case conditions for conventional diesel in the four transport modes analyzed in this study*

\begin{tabular}{|c|c|c|c|c|}
\hline \multirow[b]{2}{*}{ Transport Mode } & \multicolumn{2}{|c|}{ Current Conditions } & \multicolumn{2}{|c|}{2020} \\
\hline & $\begin{array}{l}\text { Estimated } \\
\text { Annual Gross } \\
\text { Tonne } \\
\text { Kilometers } \\
\text { (in billions) }\end{array}$ & $\begin{array}{l}\text { Total } \\
\text { Petroleum } \\
\text { Displacement } \\
\text { for B20 (tonnes } \\
\text { crude oil) }\end{array}$ & $\begin{array}{l}\text { Estimated } \\
\text { Annual Gross } \\
\text { Tonne } \\
\text { Kilometers } \\
\text { (in billions) }\end{array}$ & $\begin{array}{l}\text { Total } \\
\text { Petroleum } \\
\text { Displacement } \\
\text { for B20 (tonnes } \\
\text { crude oil) }\end{array}$ \\
\hline Rail Transport-Freight & 320 & 130,000 & 1,100 & 460,000 \\
\hline Rail Transport-Passenger & 230 & 160,000 & 420 & 290,000 \\
\hline Road Transport-Freight & 660 & $1,400,000$ & 4,400 & $9,000,000$ \\
\hline Road Transport-Passenger & 1,300 & $3,500,000$ & 2,100 & $5,700,000$ \\
\hline Total-All Analyzed Modes & 2,500 & $5,200,000$ & 8,000 & $15,000,000$ \\
\hline
\end{tabular}

* Figures rounded to two significant figures as an indication of their uncertainty. Columns may not sum due to independent rounding of each value to two significant figures.

\subsubsection{Greenhouse Gas Emission Reductions}

GHG-emission reductions can also be projected for each sector using the annual GTK values and the base case GHG-emission factors from Table 15. For the rail passenger and freight transportation sectors, annual GHG emissions that could potentially be reduced by substituting conventional diesel with B20 are estimated to be $420,000 \mathrm{mtCO}_{2} \mathrm{e}$ and $350,000 \mathrm{mtCO}_{2} \mathrm{e}$ under current conditions, respectively. For the road transport sector, potential savings under current conditions from freight transport and bus passenger transport could reach up to 3.5 million $\mathrm{mtCO}_{2} \mathrm{e}$ and 9.1 million $\mathrm{mt} \mathrm{CO}_{2} \mathrm{e}$ respectively. Given India's national GHG emissions inventory of approximately 1,800 million $\mathrm{mtCO}_{2} \mathrm{e} / \mathrm{yr}$ in 2006 with $6 \%$ of $\mathrm{GHG}$ emissions from the transport sector (Pew Center on Global Climate Change 2008), the combined savings for a full substitution of B20 for conventional diesel in the analyzed road and rail sectors could have been $0.7 \%$ of India's national GHG emissions or $12 \%$ of India's transport sector GHG emissions. By 2020 , the potential total GHG-emission reduction resulting from a full substitution of B20 for conventional diesel in the four transportation sectors analyzed in this study is estimated at approximately 40 million $\mathrm{mtCO}_{2} \mathrm{e} / \mathrm{yr}$.

Table 54. Projected net life cycle GHG emission reductions for complete substitution of Jatropha B20 produced under base case conditions for conventional diesel in the four transport modes analyzed in this study*

\begin{tabular}{|c|c|c|c|c|}
\hline \multirow[b]{2}{*}{ Transport Mode } & \multicolumn{2}{|c|}{ Current Conditions } & \multicolumn{2}{|c|}{2020} \\
\hline & $\begin{array}{l}\text { Estimated } \\
\text { Gross Tonne } \\
\text { Kilometers } \\
\text { (in billions) }\end{array}$ & $\begin{array}{l}\text { Total GHG } \\
\text { Emission } \\
\text { Reductions for } \\
\mathrm{B} 20\left(\mathrm{mtCO}_{2} \mathrm{e}\right)\end{array}$ & $\begin{array}{l}\text { Estimated } \\
\text { Gross Tonne } \\
\text { Kilometers } \\
\text { (in billions) }\end{array}$ & 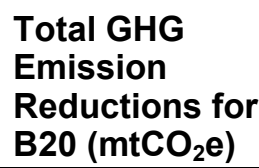 \\
\hline Rail Transport-Freight & 320 & 350,000 & 1,100 & $1,200,000$ \\
\hline Rail Transport-Passenger & 230 & 420,000 & 420 & 760,000 \\
\hline Road Transport-Freight & 660 & $3,500,000$ & 4,400 & $23,000,000$ \\
\hline Road Transport-Passenger & 1,300 & $9,100,000$ & 2,100 & $15,000,000$ \\
\hline Total-All Analyzed Modes & 2,500 & $13,000,000$ & 8,000 & $40,000,000$ \\
\hline
\end{tabular}

* Figures rounded to two significant figures as an indication of their uncertainty. Columns may not sum due to independent rounding of each value to two significant figures. 


\subsubsection{Transport Sector Comparison for Current Conditions and 2020}

The approximate amounts of biodiesel required for the complete substitution of B20 for petroleum diesel for each transport mode are shown in Table 55. Estimates are based on base case fuel economy assumptions for each transport mode evaluated in this study.

Estimates for required cultivated land to completely replace $20 \%$ of diesel fuel requirements for the evaluated transportation sectors can be made based on an assumed yield. We provide this estimate not as a prediction that such lands will be available but rather to compare to at least one estimate of available land to offer a preliminary check that the cultivation of Jatropha is feasible at the scale required under Indian policy. For this assessment, we assume a yield of 1,300-1,400 liters of biodiesel per hectare of Jatropha cultivated under the base case conditions considered in this study. In the near term, approximately 4.8 million hectares of land would have needed to be cultivated to meet B20 fuel substitution requirements for the four transportation sectors analyzed in this study. By 2020, the required amount of land would grow to over 14 million hectares. The Planning Commission (2003) identified 13.4 million hectares of land as suitable for Jatropha cultivation. That the amount of land identified by the Planning Commission nearly equals the land required for full B20 substitution does not imply a prediction that transitioning such a large, diverse and geographically disparate amount of land to Jatropha cultivation would be economically, politically and logistically achievable. Also, these projections do not account for population growth, increasing affluence and other socio-economic and demographic changes that could impact the availability of land for Jatropha cultivation. Despite these limitations, it would appear that the amount of available land is of a similar order of magnitude to support the fulfillment of Indian policy for biodiesel substitution. 
The Planning Commission noted that only about half the available land is abandoned, fallow, or wasteland, whereas the other half is composed of under-stocked forestland or farm land that requires protective hedging. Use of plantation sites with significant levels of current vegetation could increase GHG emissions related to direct land-use change, though, as shown in the bounding analysis in Section 8.1, the likely magnitude of the increase in GHG emissions is small. If determining robust estimates of the potential GHG emissions associated with the set of specific land tracts identified for Jatropha cultivation is important, then additional research on the topic of GHG emissions associated with land use change should be prioritized.

Table 55. Estimated amounts of biodiesel required to completely substitute Jatropha B20 for allpetroleum diesel for the four transport modes analyzed in this study*

\begin{tabular}{|c|c|c|c|c|}
\hline \multirow[b]{2}{*}{ Transport Mode } & \multicolumn{2}{|c|}{ Current Conditions } & \multicolumn{2}{|c|}{2020} \\
\hline & $\begin{array}{l}\text { Estimated } \\
\text { Gross Tonne } \\
\text { Kilometers } \\
\text { (in billions) }\end{array}$ & $\begin{array}{l}\text { Estimated } \\
\text { Liters Biodiesel } \\
\text { Required } \\
\text { (in millions) }\end{array}$ & $\begin{array}{l}\text { Estimated } \\
\text { Gross Tonne } \\
\text { Kilometers } \\
\text { (in billions) }\end{array}$ & $\begin{array}{l}\text { Estimated } \\
\text { Liters Biodiesel } \\
\text { Required } \\
\text { (in millions) }\end{array}$ \\
\hline Rail Transport-Freight & 320 & 170 & 1,100 & 580 \\
\hline Rail Transport-Passenger & 230 & 200 & 420 & 370 \\
\hline Road Transport-Freight & 660 & 1,700 & 4,400 & 11,000 \\
\hline Road Transport-Passenger & 1,300 & 4,400 & 2,100 & 7,100 \\
\hline Total-All Analyzed Modes & 2,500 & 6,500 & 8,000 & 19,000 \\
\hline
\end{tabular}

${ }^{*}$ Figures rounded to two significant figures as an indication of their uncertainty. Columns may not sum due to independent rounding of each value to two significant figures.

As Table 53 and Table 54 show, the potential petroleum consumption and GHG-emission reductions for a complete substitution of B20 in the road sector account for approximately $95 \%$ of estimated total reductions under current conditions. By 2020, the road sectors' potential share of petroleum consumption and GHG-emission reductions is projected to exceed $95 \%$ as the modal share of transport in India shifts even further toward road. While substitution of B20 for petroleum diesel in the rail sector in the near term may be the simplest to execute because of a smaller demand for biodiesel and because of a greater degree of centralization of refueling locations for locomotives, the greatest near-term, potential impact would come from an investment in a B20 fueling infrastructure for passenger buses. Over time, as more biodiesel becomes available, the B20 refueling infrastructure could be expanded to include more roadside refueling stations to enable B20 substitution in road-freight transport. In the long term, however, it is projected that substitution of B20 for petroleum diesel in road-freight transport will yield the greatest potential absolute reductions in both petroleum consumption and GHG emissions, though only if the required amount of biodiesel and the necessary refueling infrastructure are available. 


\section{Conclusions}

India's transportation sector relies heavily on imported petroleum-based fuels. The Planning Commission of India and the Indian government recommended increased use of blended biodiesel in transportation fleets and identified Jatropha as a potentially important feedstock. IOC and IR are collaborating to increase the use of biodiesel blends up to B20 in Indian transport vehicles, and the Planning Commission (2003) and later the Ministry of New \& Renewable Energy (2009) has set a goal of offsetting 20\% of transport-sector diesel consumption with biodiesel by 2017 . This study evaluated the life cycle GHG emissions, net energy value, and petroleum displacement impacts of integrating larger percentages of Jatropha-based biodiesel in transport vehicle operations in India and identified the parameters that have the greatest impact on selected attributes of sustainability of the system. This study was designed to evaluate Jatropha cultivation, biodiesel production, and biodiesel blend utilization under Indian conditions to the greatest degree possible.

For the base case considered, this study found that, per MJ of fuel energy content, a blend of B20 would reduce GHG emissions by $14 \%$, reduce petroleum consumption by $17 \%$ and increase the net energy value by $58 \%$ compared with the conventional diesel baseline. These results suggest that the Jatropha-based biodiesel system under consideration can achieve the identified sustainability goals of reducing net GHG emissions and displacing petroleum consumption. Using sensitivity analyses, this study also identified dry seed yield, seed oil content, and biodiesel fuel consumption efficiency as critical parameters that individually exert the greatest influence on the evaluated sustainability and energy security metrics. This study also confirmed that reductions in the GHG emissions and petroleum consumption are maintained under multiple plausible biodiesel cultivation, processing, and distribution scenarios, though GHG emission reductions compared to petroleum diesel are reduced to zero if seed yield fall below 1,250 kg / ha-yr. Furthermore, while the base case did not consider the potential impacts of direct land-use change, a bounding estimate using results from Reinhardt et al. (2008) found that the magnitude and direction of benefits would likely not change considerably even if those potential impacts were considered.

As agro-climatic conditions and optimal biodiesel feedstocks vary widely throughout the world, no one study can definitively determine the sustainability of biofuels in all scenarios. However, the results of this study and other reviewed studies suggest that under plausible growing conditions and production scenarios, Jatropha-based biodiesel shows promise for helping India achieve its GHG-emission reduction and petroleum displacement goals, with the greatest absolute potential reductions being achievable in the road bus, passenger transport sector in the near term and in the road-freight transport sector in 2020. However, as cultivation expands to the scale required to meet the mandated biodiesel production levels, seed and oil yields and the intensity of cultivation inputs must be closely evaluated in assessing the sustainability of any individual proposed Jatropha biodiesel production project. 


\section{Research Recommendations}

With the results of this study and the influence of uncertain individual parameters as shown in the sensitivity analyses in mind, four topics of future research are prioritized.

1. Additional field trial-based data sets and predictive models are needed to forecast anticipated seed yield, oil content, fertilizer use, and irrigation requirements based on a wider variety of agro-climate conditions. Such models would allow policymakers and decision makers can determine the economic viability and environmental effects of proposed projects.

2. Economic and market penetration analyses are required to evaluate the feasibility of large scale adoption of B20 using Jatropha biodiesel including anticipated direct and indirect land use impacts, potential for use of marginal lands versus prime agricultural lands, economic impact on Jatropha farmers and local communities, and market availability for Jatropha biodiesel co-products. Economic and market analyses will also assist in framing scenarios for analyses like the current study.

3. Viable co-product substitution scenarios for all Jatropha cultivation activities and biodiesel production processes need to be developed for India-specific economic and technological conditions. Particular research is needed on the use of glycerine, combustion of seed husks, and use of the de-oiled Jatropha seed cake.

4. Research on other sustainability metrics, e.g., water consumption, air, soil, and water quality, and economic and gender equity, are required to more fully understand the impacts of large-scale expansion of Jatropha biodiesel production and use on both the environment and the local population. 


\section{References}

Achten W. M. J.; Verchot L; Franken Y. J .; Mathijs, E.; Singh, V. P.; Aerts R.; Muys, B. (2008). "Jatropha Bio-diesel Production and Use." Biomass and Bioenergy (31:12); pp. 1063-1084. doi: 10.1016/j.biombioe.2008.03.003.

Adriaans, T. (2006). "Sustainability of Solvent Extraction for Jatropha Curcas." Prepared for FACT Foundation, November 2006. http://www.fact-fuels.org/media en/FACT_(2006)_Suitability of solvent extraction_for_jatropha_curcas Accessed July 29, 2008.

Argonne National Laboratory. (2009). "The Greenhouse Gases, Regulated Emissions, and Energy Use in Transportation (GREET) Model,” March 23, 2009. http://www.transportation .anl.gov/modeling_simulation/GREET/ Accessed January 08, 2010.

Basha, S.; Gopal, K.; Jebaraj, S. (2009). "A Review on Biodiesel Production, Combustion, Emissions and Performance." Renewable and Sustainable Energy Reviews (13:6-7); pp. 16281634.

Bureau of Energy Efficiency, Ministry of Power, Government of India. (2008). "Mathura Refinery - Indian Oil Corporation Limited - Mathura (Uttar Pradesh)." http://www.emtindia.net/eca2005/Award2005CD/AwardBook/Refinery.pdf Accessed February 10, 2010.

Chhattisgarh Online. (2008). "Raipur." http://chhattisgarhonline.in/profile/districts/Raipur.asp Accessed September 6, 2008.

Crutzen, P. J.; Mosier, A. R.; Smith, K. A.; Winiwarter, W. (2008). " $\mathrm{N}_{2} \mathrm{O}$ Release from Agrobiofuel Production Negates Global Warming Reduction by Replacing Fossil Fuels." Atmos.

Chem. Phys (8); pp. 389-395. http://www.atmos-chem-phys.org/8/389/2008/acp-8-389-2008.pdf Accessed July 31, 2008.

Distance Calculator India. (2008). http://www.liveindia.com/distance/Visakhapatnam.html Accessed November 12, 2008.

Distances.com (2008) "World Port Distances Calculator," Available Online: http://www.distances.com. Last Accessed: June 19, 2008.

Dunn, R. (2003). "Biodiesel as a Locomotive Fuel in Canada." Prepared for Transportation Development Centre, Transport Canada, May 2003. TP 14106E. Montreal, Quebec:

Transportation Development Centre. http://www.tc.gc.ca/innovation/tdc/publication/pdf/14100/ 14106e.pdf Accessed January 11, 2010.

European Automobile Manufacturers Association. (2009). "Commercial Vehicles and $\mathrm{CO}_{2}$ : The Business of Fuel Economy." http://www.acea.be/images/uploads/files/20090317_CV brochure.pdf Accessed August 24, 2009.

Farrell, A.; Plevin, R.; Turner, B.; Jones, A.; O’Hare, M.; Kammen, D. (2006). "Ethanol Can Contribute to Energy and Environmental Goals." Science 27 (311:5760); pp. 506-508.

doi:10.1126/science.1121416. 
Global Exchange for Social Investment. (2008). "Global Market Study on Jatropha: Final Report." Prepared for the World Wide Fund for Nature, May 8, 2008. http://www.jatrophaplatform.org/documents/GEXSI_Global-Jatropha-Study FULL-REPORT.pdf Accessed January 12, 2010.

Gubler, R. (2006). "Biodiesel" Chemical Economics Handbook Marketing Report. Menlo Park, CA: SRI Consulting, November 2006.

Hindustan Petroleum Corporation Limited. (2008). "Annual Report 2007-2008." http://www .hindustanpetroleum.com/Upload/En/AnnualReports/Files/AnnualReport2007-08.pdf Accessed January 12, 2010.

Indian Central Electricity Authority. (2008). "Highlights of Power Sector." http://cea.nic.in/ power_sec_reports/Executive_Summary/2008 04/1-2.pdf Accessed June 19, 2008.

Indian Railways. (2008). "Annual Report and Accounts: 2006-2007: Financial Statements and Operating Statistics." http://www.indianrailways.gov.in/deptts/yearbook/annual-rep-0607/fin -stmt-optg-stmt.pdf Accessed January 12, 2010.

Intergovernmental Panel on Climate Change (IPCC). (2006). "2006 IPCC Guidelines for National Greenhouse Gas Inventories." Prepared by the National Greenhouse Gas Inventories Programme, edited by: Eggleston, H.S., Buendia, L., Miwa, K., Ngara, T.; Tanabe, K. Volume 4, Chapter 11, Table 11.1, $\mathrm{N}_{2} \mathrm{O}$ Emissions from Managed Soils, and $\mathrm{CO}_{2}$ Emissions from Lime and Urea Application. Hayama, Japan: Institute for Global Environmental Strategies (IGES).

IPCC. (2007). "Contribution of Working Group I to the Fourth Assessment Report of the Intergovernmental Panel on Climate Change, 2007, chap. 2.10.2: Direct Global Warming Potentials. ” Ed. Solomon, S., Qin D.; Manning, M.; Chen Z.; Marquis M.; Averyt, K. B.; Tignor, M.; Miller H. L. Cambridge and New York: Cambridge University Press. http://www.ipcc.ch/publications_and_data/ar4/wg1/en/ch2s2-10-2.html.

International Energy Agency. (2009). “Oil in India in 2006.” http://iea.org/stats/oildata.asp? COUNTRY_CODE=IN Accessed October 20, 2009.

International Organization for Standardization (ISO). (2006). "Environmental Management Life Cycle Assessment - Requirements and Guidelines.” ISO 14044:2006. Geneva, Switzerland: ISO.

Jongschaap, R. E. E.; Corre, W. J.; Bindraban, P. S.; Brandenburg, W. A. (2007). "Claims and Facts on Jatropha curcas L.: Global Jatropha curcas Evaluation, Breeding and Propagation," Plant Research International, Report 158, October 2007.

Kathpal, A. K. (2008). "Use of Biodiesel as a Traction Fuel for Indian Railways - A Case Study," 1st Workshop on Railways and Biofuel at UIC, Paris. http://www.uic.asso.fr/reunion.php/19822/ 4 kathpal_biodiesel_roadmap_indian_railways.pps Accessed July 25, 2008.

Kheira, A.; Atta, N. (2008). "Response of Jatropha curcas L. to Water Deficit: Yield, Water Use Efficiency and Oilseed Characteristics." Biomass and Bioenergy (33:10); pp. 1343-1350.

doi:10.1016/j.biombioe.2008.05.015 
LANXESS. (2009). "Baynox - Further Information." http://www.baynox.com/bac/en/products/ baynox/further_information/ Accessed August 20, 2009.

Lele, S. (2008a). "Jatropha Cultivation," March 2008. http://www.svlele.com. Accessed June 19, 2008 .

Lele, S. (2008d). "Biodiesel," March 2008. http://www.svlele.com Accessed June 19, 2008.

Lele, S. (2008c). "Project Report for 1,000 Liters per Day BioDiesel Plant." http://www .svlele.com/biodiesel_1tpd.htm Accessed June 19, 2008.

Lele, S. (2008b). "Project Report for Jatropha Plantation," Excel Workbook, March 2008.

Leng, R.; Wang, C.; Zhang, C.; Dai, D.; Pu, G. (2008). "Life Cycle Inventory and Energy Analysis of Cassava-based Fuel Ethanol in China." Journal of Cleaner Production (16:3); pp. 374-384. doi:10.1016/j.jclepro.2006.12.003.

Lloyd, S.; Ries, R. (2007). "Characterizing, Propagating, and Analyzing Uncertainty in LifeCycle Assessment: A Survey of Quantitative Approaches." Journal of Industrial Ecology (11:1); pp. 161-179. doi: 10.1162/jiec.2007.1136

Maps of India. (2009). "Distance Chart from Raipur to over Hundreds of Cities and Towns." http://www.mapsofindia.com/distances/raipur.html Accessed August 12, 2009.

Metropolitan Transport Corporation, Ltd. Chennai. (2009a). "Performance Indicators." http://www.mtcbus.org/faq.asp Accessed August 26, 2009.

Metropolitan Transport Corporation, Ltd. Chennai. (2009b). "Services - Bus Types - Latest Info." http://www.mtcbus.org/faq.asp Accessed August 26, 2009.

Ministry of New \& Renewable Energy, Government of India. (2009). "National Policy on Biofuels." http://www.mnre.gov.in/policy/biofuel-policy.pdf Accessed on May 5, 2010.

Ministry of Petroleum and Natural Gas, Government of India. (2006). "Review of Crude Oil Production During the Month of October 2005 and Cumulatively for the Period April - October 2005 Vis-à-vis 2004." Annexure-I, Page 1. http://petroleum.nic.in/Monthly_Production/P Oct 05.pdf Accessed December 2, 2008.

Ministry of Railways, Government of India. (2008). "Indian Railways: Annual Statistical Statements: 2007-2008," p. 153. http://www.indianrailways.gov.in/deptts/yearbook/ASS 0708.pdf Accessed November 23, 2009.

Ministry of Railways, Government of India. (2003). "Indian Railways to Use Bio-diesel Fuels, Signs MOU with IOC for Production of Bio-Diesel.” Press release. February 12, 2003. http://pib.nic.in/archieve/lreleng/lyr2003/rfeb2003/12022003/r120220033.html Accessed September 6, 2008.

Ministry of Shipping, Road Transport, and Highways (MSRTH), Government of India. (2009). "Road Transport Year Book 2006-07." New Delhi, March 2009, http://www.morth.nic.in/ 
writereaddata/sublink2images/RoadTransport2006_07_Book292768426.pdf Accessed October 20, 2009.

Ndong, R.; Montrejaud-Vignoles, M.; Saint Girons, O.; Gabrielles, B.; Pirot, R.: Domergue, M.; Sablayrolles, C. (2009). "Life Cycle Assessment of Biofuels from Jatropha curcas in West Africa: A Field Study." GCB Bioenergy (2009:1); pp.197-210. doi: 10.1111/j.1757-1707 .2009.01014.x.

Nivitchanyong, S. (2007). "Zero Waste Agriculture for Jatropha Plantation." Presented at the 4th Biomass Asia Workshop, Shah Alam, Malaysia November 20-22, 2007.

Padma, T.V. (2008). "India Approves Biofuel Rise," September 17, 2008. http://www.scidev.net/ en/news/india-approves-biofuel-rise.html Accessed September 23, 2008.

Pew Center on Global Climate Change. (2008). "Climate Change Mitigation Measures in India," International Brief 2, September 2008. http://pewclimate.org/docUploads/India-FactSheet-09 -08.pdf Accessed December 1, 2008.

Planning Commission, Government of India. (2003). "Report of the Committee on Development of Bio-fuel," New Delhi, India April 13, 2003.

Planning Commission, Government of India. (2007). "India Vision 2020: The Report plus Background Papers," Report of the Committee on India Vision 2020, Planning Commission, Government of India, Chairman S.P. Gupta, New Delhi.

Prueksakorn K.; Gheewala, S. H. (2006). "Energy and Greenhouse Gas Implications of Biodiesel Production from Jatropha curcas L.," in Proceedings of the Second Joint International Conference on Sustainable Energy and Environments.

Prueksakorn, K.; Gheewala, S. H. (2008). "Full Chain Energy Analysis of Biodiesel from Jatropha curcas L. in Thailand." Environmental Science \& Technology (42:9); pp. 3388-3393. doi: $10.1021 /$ es 7022237

Puri, Suresh (IOC) (2009). Personal communication to Garvin Heath (NREL), August 19, 2009.

Raipur Government, Districts of Chhattisgarh. (2009). "Tourism." http://raipur.nic.in/tourism .htm Accessed August 12, 2009.

Reinhardt, G.; Becker, K; Chaudhary, D. R.; Chikara, J.; von Falkenstein, E.; Francis, G.; Gärtner, S.; Gandhi, M. R.; Ghosh, A.; Ghosh, P.; Makkar, H.; Münch, J.; Patolia, J. S.; Reddy, M. P.; Rettenmaier, N.; Upadhyay, S. C. (2008). "Basic Data for Jatropha Production and Use," Updated Version, Institute for Energy and Environmental Research Heidelberg GmbH, Central Salt \& Marine Chemicals Research Institute, Bhavnagar, University of Hohenheim Institute of Animal Production in the Tropics and Subtropics, June 2008.

Reinhardt, G.; Gartner, S.; Rettenmaier, N.; Munch, J.; von Falkenstein, E. (2007). "Screening Life Cycle Assessment of Jatropha Biodiesel." Commissioned by Daimler AG, Stuttgart, Prepared by the Institute for Energy and Environmental Research Heidelberg GmbH, December 11, 2007. 
Renewable Energy U.K. (2008). "Jatropha for Biodiesel Figures: Look at the Financial Costs for Jatropha Growing for Biodiesel," November 2, 2007. http://www.reuk.co.uk/Jatropha-for -Biodiesel-Figures.htm Accessed July 25, 2008.

Renewable Fuels Agency, U.K. (2009). "Carbon and Sustainability Reporting Within the Renewable Transport Fuel Obligation: Technical Guidance Parts 1 and 2," Version 2.0 March 2009.

Republic Bag. (2008). http://republicbag.com/formulas.html Accessed July 29, 2008.

Sarin, Rakesh (IOC) (2008a). Personal communication (word-processed document) to Garvin Heath (NREL), May 14, 2008.

Sarin, Rakesh (IOC) (2008b). Personal communication to Garvin Heath (NREL), June 17, 2008.

Sarin, Rakesh (IOC) (2008c). Personal communication to Garvin Heath (NREL), July 15, 2008.

Sarin, Rakesh (IOC) (2008d). Personal communication to Garvin Heath (NREL), July 28, 2008.

Sarin, Rakesh (IOC) (2008e). Personal communication to Garvin Heath (NREL), November 11, 2008.

Scientific Applications International Corporation. (2006). "Life Cycle Assessment: Principles and Practice." Prepared for the U.S. Environmental Protection Agency, May 2006. EPA/600/R06/060. Reston, VA: SAIC. http://www.epa.gov/nrmrl/lcaccess/pdfs/600r06060.pdf Accessed December 2, 2008.

Sheehan, J.; Camobreco, V.; Duffield, J.; Graboski, M.; Shapouri, H. (1998). "Life Cycle Inventory of Biodiesel and Petroleum Diesel for Use in an Urban Bus." NREL/SR-580-24089. Golden, CO: National Renewable Energy Laboratory (May 1998).

Singh, A.; Gangopadhyay, S.; Nanda, P. K.; Bhattacharya, S.; Sharma, C.; Bhan, C. (2008). "Trends of Greenhouse Gas Emissions from the Road Transport Sector in India." Science of the Total Environment (390:1); pp. 124-131. doi:10.1016/j.scitotenv.2007.09.027.

Singh, S. K. (2008). "CO 2 Emissions from Passenger Transport in India: 1950-51 to 2020-21." Better Air Quality 2008 conference publication, Bangkok, Thailand. http://www.baq2008 .org/system/files/stream2_Singh+poster.pdf Accessed November 23, 2009.

Singh, S. K. (2005). "Review of Urban Transportation in India.” Journal of Public

Transportation (8:1); pp. 79-97. http://www.nctr.usf.edu/jpt/pdf/JPT 8-1 Singh.pdf Accessed October 20, 2009.

Skinner, I.; Hill, N.; Kollamthodi, S.; Mayhew, J.; Donnelly, B. (2007). "Railways and Biofuel," First International Union of Railways Report, July 2007.

Sreenivas, A.; Sant, G. (2008). "Unravelling Myths about Subsidies in Urban Transport: A Case Study of Pune.” Prayas Energy Group, August 2008. http://www.cseindia.org/campaign/apc/pdf/ urban_transport_subsidy_myths_093A01.pdf Accessed October 20, 2009. 
SRS Engineering Corporation. (2009). "Methanol Recovery." http://www.srsbiodiesel.com/ MethanolRecovery.aspx Accessed August 19, 2009.

Swiss Centre for Life Cycle Inventories. (2008). "Ecoinvent Centre Portal: The Ecoinvent Database." http://www.ecoinvent.org/ Accessed November 24, 2008.

TDS Chemical. (2009). "Cetane-707 (Cetane Improver)." http://www.tdschem.com/UploadFile/ Cetane-707 Overview.pdf Accessed August 20, 2009.

The Climate Registry. (2008). "General Reporting Protocol - Version 1.1," May 2008. http://www.theclimateregistry.org/downloads/GRP.pdf Accessed July 29, 2008

U.S. Climate Change Technology Program, U.S. (2005). "Technology Options for the Near and Long Term: Thermochemical Conversion of Biomass" August 2005. http://www .climatetechnology.gov/library/2005/tech-options/tor2005-236.pdf Accessed September 6, 2008.

U.S. Energy Information Administration, U.S. (2007a). "Country Analysis Brief - India," Last updated January 2007. http://www.eia.doe.gov/emeu/cabs/India/Full.html Accessed December 1, 2008.

U.S. Energy Information Administration, U.S. (2007b). "Table: World Net Electricity Generation by Type, 2005." Posted September 17, 2007.

http://www.eia.doe.gov/emeu/international/

electricitygeneration.html Accessed June 19, 2008.

U.S. Environmental Protection Agency, U.S. (2009). "Fast Facts - The U.S. Inventory of Greenhouse Gas Emissions Inventory." Washington D.C. http://www.epa.gov/climatechange/ emissions/downloads/2009GHGFastFacts.pdf Accessed January 12, 2010.

Van Gerpen, J. (2009). "National Biodiesel Education Program, Technical Questions: A Sample of Questions Directed to the University of Idaho Biodiesel Education Project."

Whitaker, M. (2007). "Life Cycle Assessment of Transit Systems in the U.S. and India: Implications for a Carbon-Constrained Future." PhD diss, University of Colorado Denver, Civil Engineering, 2007.

Whitaker, M.; Heath, G. (2009). Life Cycle Assessment of the Use of Jatropha Biodiesel in Indian Locomotives. NREL/TP-6A2-44428. Golden, CO: National Renewable Energy Laboratory, March 2009. http://www.nrel.gov/docs/fy09osti/44428.pdf Accessed October 20, 2009.

Wintek Corporation. (2009). "Methanol Recovery." http://www.wintek-corp.com/ biodiesel/methanol-recovery.html Accessed August 19, 2009.

World Port Source. (2008). http://worldportsource.com/ Accessed July 29, 2008. 


\section{Appendix: SimaPro Model and Base Case Model Parameter Values}

Appendix A contains tables detailing the contents of the custom modules developed to construct the SimaPro model and the base case model parameter values. These custom modules were introduced in Section 4. Tables A-1 and A-2 list all relevant parameters in the study along with their abbreviations, values, units, and descriptions to facilitate understanding of the custom modules. The parameters are listed in alphabetical order by abbreviation. Parameters assigned specific values are listed in Table A-1. Parameters with values that are calculated based on formulas calling other parameters listed in Table A-2. Tables A-3 through A-14 show how the custom modules are coded. Modules customized for Indian-specific diesel refining and distribution cannot be displayed in detail, as they closely resemble proprietary data in ecoinvent 2.0 modules.

Table A-1. Base case input parameters that have assigned values

\begin{tabular}{|c|c|c|}
\hline $\begin{array}{l}\text { Input Parameter } \\
\text { Name }\end{array}$ & Value & Description (Source) \\
\hline annual_rain & 1385 & $\begin{array}{l}\mathrm{mm} \text {, average rainfall in Raipur province, Chhattisgarh, India, the } \\
\text { plantation's assumed location according to IOC. Used to calculate } \\
\text { parameter rainfall_def to evaluate amount of irrigation water needed for } \\
\text { the site (Chhattisgarh Online } 2008, \text { p. } 1 \text { ) }\end{array}$ \\
\hline bio_blend_elec & 0.00086 & $\begin{array}{l}\mathrm{kWh} / \mathrm{kg} \text {, energy required to blend ethanol with gasoline, assuming similar } \\
\text { requirement for blending biodiesel with diesel. Used as an } \\
\text { Electricity/heat input in the "Blended Biodiesel, India, At Processing } \\
\text { Facility" module (Leng et al. 2008, p. 381). Sensitivity could assume no } \\
\text { electricity consumption if fuels are flash blended. }\end{array}$ \\
\hline bio_elec_eff & 0.25 & $\begin{array}{l}\text { assumed efficiency of converting solid biofuel to electricity (U.S. Climate } \\
\text { Change Technology Program 2005) }\end{array}$ \\
\hline bio_fuel_drop & 0.08 & $\begin{array}{l}8 \% \text {, drop in fuel economy for B100 compared with regular diesel, } \\
\text { proportional to biodiesel blend (Van Gerpen 2009) }\end{array}$ \\
\hline bio_off_switch & 1 & $\begin{array}{l}\text { Set to "1" for electricity, set to "0" for heat. Used in Jatropha Seeds } \\
\text { Harvested from Plantation module to select whether the collected } \\
\text { biomass (leaves, stems, fruit husks) is collected and converted to } \\
\text { electricity or used to offset process heat. Electricity offset Indian } \\
\text { Electricity Generated, heat offsets mixed chips from the forest burned in } \\
\text { a small furnace ( } 50 \mathrm{~kW}) \text {. }\end{array}$ \\
\hline bio_plant_life & 50 & $\begin{array}{l}\text { yrs, lifetime of biodiesel transesterification facility in ecoinvent database. } \\
\text { Used to calculate parameter "bio_prod_life" for determining how much of } \\
\text { a biodiesel plant infrastructure is apportioned to each tonne produced } \\
\text { (Swiss Centre for Life Cycle Inventories 2009) }\end{array}$ \\
\hline bio_plant_prod & 63 & $\begin{array}{l}\text { MT/day, daily production of biodiesel in ecoinvent database. Used to } \\
\text { calculate parameter "bio_prod_life" for determining how much of a } \\
\text { biodiesel plant infrastructure is apportioned to each tonne produced } \\
\text { (Swiss Centre for Life Cycle Inventories 2009) }\end{array}$ \\
\hline biodiesel_blend & 0.05 & $\begin{array}{l}\text { biodiesel/(biodiesel + diesel) for defining the blending ratio of the } \\
\text { biodiesel mix. IOC recommended evaluating B5. B10, B20, and B100 are } \\
\text { also evaluated in the sensitivity analysis. Also supported by blends } \\
\text { tested in Indian Railways trials (Kathpal 2008; Skinner et al. 2007, p. 35) }\end{array}$ \\
\hline biodiesel_dist & 25 & $\begin{array}{l}\mathrm{km} \text {, distance biodiesel must be transported from the production facility in } \\
\text { Raipur to rail depots in Bhilai where blending occurs. Used in "Biodiesel } \\
\text { Blending, India, At Processing Facility" to calculate transport distance for } \\
\text { biodiesel (Raipur Government 2009, p. 1) }\end{array}$ \\
\hline
\end{tabular}




\begin{tabular}{|c|c|c|}
\hline $\begin{array}{l}\text { Input Parameter } \\
\text { Name }\end{array}$ & Value & Description (Source) \\
\hline biodiesel_eff & 0 & $\begin{array}{l}\text { fuel economy reduction of biodiesel blend compared with conventional } \\
\text { diesel, "0" indicates no significant change in volumetric fuel consumption } \\
\text { as indicated by Indian Railway studies finding negligible negative effects } \\
\text { in volumetric fuel consumption for B5, B10, B20. Used in "Indian Rail } \\
\text { Transport" and "Indian Road Transport" modules to determine fuel } \\
\text { consumption of blended biodiesel relative to a diesel (Kathpal 2008; } \\
\text { Skinner et al. 2007, p. 35). Potential sensitivity values of } 0.01 \text { and } 0.02 \\
\text { would represent a 1-2\% decrease in fuel economy as indicated by Dunn } \\
(2003, \text { p. } 9) \text { and U.S. Environmental Protection Agency (2008). Van } \\
\text { Gerpen (2009, p. 3) estimates a fuel economy reduction of up to } 8 \% \\
\text { (0.08) for B100, with reduction proportional with biodiesel blend percent } \\
\text { for lower blends. Biodiesel_eff in the model scales proportionally with } \\
\text { biodiesel blend so biodiesel_eff should generally be set to the maximum } \\
\text { fuel economy reduction expected if B100 is used. }\end{array}$ \\
\hline biostabilizer & 0.0025 & $\begin{array}{l}\mathrm{kg} \text { Biodiesel stabilizer/kg biodiesel (LANXESS } 2009, \mathrm{p} .6 \text { ). Biodiesel } \\
\text { stabilizers mimic vitamin E and are added in a ratio of } 0.1-0.5 \text { volume } \% \text {. } \\
\text { Data on India-specific biodiesel stabilizers are not available. }\end{array}$ \\
\hline bus_dies_cons & 3.94 & $\begin{array}{l}\mathrm{km} / \text { liter diesel, fleet average for the buses of the Metropolitan Transport } \\
\text { Corporation (MTC), Chennai, India during 2007-2008 (Metropolitan } \\
\text { Transport Corporation 2009a) }\end{array}$ \\
\hline bus_weight & 15 & $\begin{array}{l}\text { tonnes, according to Metropolitan Transport Corporation (2009b), the } \\
\text { majority of MTC's fleet is comprised of Ashok Leyland buses. According } \\
\text { to Whitaker (2007), a common Ashok Leyland bus is the Viking } 222 \mathrm{with} \\
\text { a gross vehicle weight (vehicle plus cargo and passengers) of } 15,430 \mathrm{~kg} \\
\text { and passenger capacity of } 48 \text { (Table } 2.11, \mathrm{p} \text {. 42). With an average } \\
\text { occupancy of } 81 \% \text { (Metropolitan Transport Corporation } 2009 \mathrm{a} \text { ), the } \\
\text { author's estimate that the operational weight of the buses will average } \\
\text { approximately } 15 \text { tonnes (rounded to the nearest tonne) for purposes of } \\
\text { converting fuel consumption per vehicle kilometer to fuel consumption } \\
\text { per gross tonne kilometer. }\end{array}$ \\
\hline cal_val_bio & 39500 & $\begin{array}{l}\mathrm{kJ} / \mathrm{kg} \text {, calorific value of biodiesel included to calculate parameter } \\
\text { "cal_val_blend" that can be used to adjust result to per MJ of blended } \\
\text { fuel_(Sarin 2008a, p. 4) }\end{array}$ \\
\hline cal_val_diesel & 42000 & $\begin{array}{l}\mathrm{kJ} / \mathrm{kg} \text {, calorific value of diesel included to calculate parameter } \\
\text { "cal_val_blend" that can be used to adjust result to per MJ of blended } \\
\text { fuel (Sarin 2008a, p. 4) }\end{array}$ \\
\hline cetane_enhancer & 0.001 & $\begin{array}{l}\mathrm{kg} \text { cetane enhancer } / \mathrm{kg} \text { diesel fuel, modeled as generic inorganic } \\
\text { chemical to substitute for actual 2-ethylhexyl nitrate production. Range } \\
\text { listed as } 0.00025-0.002 \mathrm{~kg} / \mathrm{kg} \text { (TDS Chemical 2009, p. 1) }\end{array}$ \\
\hline CO2_bio & 0 & $\begin{array}{l}\mathrm{kg} \mathrm{CO}_{2} / \text { liter of B100 combusted. Emission factor taken from The Climate } \\
\text { Registry (2008, p. 93, Table 13.1). Used to calculate parameter } \\
\text { "CO2_biodiesel." }\end{array}$ \\
\hline CO2_dies & 2.68 & $\begin{array}{l}\mathrm{kg} \mathrm{CO}_{2} \text { /liter of diesel combusted. Emission factor taken from The Climate } \\
\text { Registry (2008, p. 93, Table 13.1). Used to calculate parameter } \\
\text { "CO2_diesel." }\end{array}$ \\
\hline crude_foreign & 0.75 & $\begin{array}{l}\text { fraction of IOC crude oil from foreign sources (Middle East and Nigeria). } \\
\text { Used to calculate parameters "crude_bombay", "crude_mid_east", and } \\
\text { "crude_Nigeria" (Sarin 2008a) }\end{array}$ \\
\hline crude_offshore & 1 & $\begin{array}{l}\text { mass fraction of Indian domestic crude oil produced offshore. M. } \\
\text { Whitaker assumption for base case scenario that all domestic oil is } \\
\text { derived from the offshore field at Bombay High. The largest fraction of } \\
\text { India's domestic oil production is produced at Bombay High according to }\end{array}$ \\
\hline
\end{tabular}




\begin{tabular}{|c|c|c|}
\hline \multirow{2}{*}{$\begin{array}{l}\text { Input Parameter } \\
\text { Name }\end{array}$} & Value & Description (Source) \\
\hline & & the Ministry of Petroleum and Natural Gas (2006). \\
\hline crude_oil_trans & 600 & $\begin{array}{l}\mathrm{km} \text {, approximate distance diesel travels via rail between Vizag refinery } \\
\text { on the east coast of Andhra Pradesh and the oil depots in Bhilai near } \\
\text { Raipur for fueling IR locomotives and trucks at the Bhilai depots (Maps of } \\
\text { India 2009), distance from Raipur to Vishakhapatnam }\end{array}$ \\
\hline diesel_fuel_con & 2.63 & $\begin{array}{l}\text { liters diesel/1000 gross tonne kilometers transported via locomotive for } \\
\text { freight transport. Indian trains that run on broad gauge tracks are more } \\
\text { fuel efficient than those that run on narrow gauge. Freight transport more } \\
\text { often requires and utilizes broad gauge track. } 4.38 \mathrm{~L} / 1,000 \mathrm{GTK} \text { used to } \\
\text { model passenger transport fuel economy (this value was used in the } \\
\text { initial report). Both data points are from Indian Railways (2008, p. 17). } \\
\text { Used to calculate fuel consumption in Indian Freight Train module based } \\
\text { on biofuel blend. Use "rail_switch" to shift analysis between freight and } \\
\text { passenger modes. }\end{array}$ \\
\hline diesel_fuel_cul & 86 & $\begin{array}{l}\text { L/ha-yr, based on Reinhardt et al.'s "optimized" scenario for diesel fuel } \\
\text { use on a plantation with tree density of } 1,667 \text { trees/hectare. Sensitivity } \\
\text { values of } 141 \text { L/ha-yr for the "best" scenario and } 55 \text { L/ha-yr for the low } \\
\text { production of "today's" conditions can be used. All data points from } \\
\text { Reinhardt et al. ( } 2008, \text { Table } 2-12 \text { ). Used in Jatropha Seeds Harvest } \\
\text { from Plantation Module. }\end{array}$ \\
\hline elec_gen_coal & 0.7 & $\begin{array}{l}\text { fraction of Indian electricity generated from coal. Estimate of actual } \\
\text { generation of India electricity from coal-fired power plants, used to } \\
\text { separate coal from gas in the larger "thermal generation" category. Used } \\
\text { in "Indian Electricity Generated" module to develop an Indian-specific } \\
\text { grid mix based on other electricity modules in the ecoinvent database } \\
\text { (Indian Central Electric Authority 2008) }\end{array}$ \\
\hline elec_gen_hydro & 0.15 & $\begin{array}{l}\text { fraction of Indian electricity generated from hydro power. Used in "Indian } \\
\text { Electricity Generated" module to develop an Indian-specific grid mix } \\
\text { based on other electricity modules in the ecoinvent database (U.S. } \\
\text { Energy Information Administration 2008) }\end{array}$ \\
\hline elec_gen_ng & 0.12 & $\begin{array}{l}\text { fraction of Indian electricity generated from natural gas. Gas generation } \\
\text { assumed to equal the total thermal generation minus the estimated } \\
\text { generation from coal. Used in "Indian Electricity Generated" module to } \\
\text { develop an Indian-specific grid mix based on other electricity modules in } \\
\text { the ecoinvent database (U.S. Energy Information Administration 2007b) }\end{array}$ \\
\hline elec_gen_nuclea & 0.02 & $\begin{array}{l}\text { fraction of Indian electricity generated from nuclear power. Used in } \\
\text { "Indian Electricity Generated" module to develop an Indian-specific grid } \\
\text { mix based on other electricity modules in the ecoinvent database (U.S. } \\
\text { Energy Information Administration 2007b) }\end{array}$ \\
\hline elec_gen_renew & 0.01 & $\begin{array}{l}\text { fraction of Indian electricity generated from renewables. Includes } \\
\text { geothermal, solar, wind, waste, and wood. Used in "Indian Electricity } \\
\text { Generated" module to develop an Indian-specific grid mix based on other } \\
\text { electricity modules in the ecoinvent database. Modeled as half solar, half } \\
\text { wind using ecoinvent modules (U.S. Energy Information Administration } \\
\text { 2007b) }\end{array}$ \\
\hline elec_TD_loss & 0.32 & $\begin{array}{l}\text { fraction of Indian electricity generated that is lost due to transmission and } \\
\text { distribution losses. Difference between energy input to distribution } \\
\text { system and energy realized by customers (as a percentage) (Indian } \\
\text { Central Electric Authority } 2008 \text {, Table } 1 \mathrm{~h} \text { ) }\end{array}$ \\
\hline fert_app_num & 2 & $\begin{array}{l}\text { fertilizer applications per year, one each at the beginning and end of the } \\
\text { rainy seasons. Used in Jatropha Seeds Harvested from Plantation } \\
\text { module (Lele 2008a, p. 44) }\end{array}$ \\
\hline
\end{tabular}




\begin{tabular}{|c|c|c|}
\hline $\begin{array}{l}\text { Input Parameter } \\
\text { Name }\end{array}$ & Value & Description (Source) \\
\hline fert_switch & 1 & $\begin{array}{l}\text { "1" uses Reinhardt numbers for fertilizer requirements, "0" uses Lele/IOC } \\
\text { numbers. }\end{array}$ \\
\hline frac_met_irr & 0.2 & $\begin{array}{l}\text { fraction of annual water requirement met by irrigation. Used to meet } \\
\text { water requirements not met by rainfall. "1" would indicate that } 100 \% \text { of } \\
\text { required water is met by irrigation. }\end{array}$ \\
\hline frac_mid_east & 1 & $\begin{array}{l}\text { assumed fraction of foreign crude oil arriving from Middle East. Foreign } \\
\text { oil arrives primarily from the Middle East and Nigeria, fractions not } \\
\text { specified (Bureau of Energy Efficiency, India 2008). Highest percentage } \\
\text { comes from Middle East, therefore onshore drilling in Saudi Arabia is } \\
\text { used to represent the foreign oil supplied to India in the base case in } \\
\text { order to simplify the modeling (U.S. Energy Information Administration } \\
\text { 2007a) }\end{array}$ \\
\hline frac_stem & 0.67 & $\begin{array}{l}\text { mass fraction of Jatropha biomass comprised of stems. Based on } \\
\text { approximate breakdown of dried plant biomass (Nivitchanyong 2007, } \\
\text { slide 8) }\end{array}$ \\
\hline furnace_eff & 0.8 & $\begin{array}{l}80 \% \text { conversion efficiency from biomass heat content to heat for end use } \\
\text { for the selected furnace in ecoinvent "Heat, mixed chips from forest, at } \\
\text { furnace } 50 \mathrm{~kW} \mathrm{CH} / \mathrm{S} \text { " Same conversion efficiency assumed for furnace } \\
\text { used in biomass heat-offset scenario. }\end{array}$ \\
\hline glyc_yield & 0.079 & $\begin{array}{l}\text { fraction yield of glycerine during Jatropha oil conversion to biodiesel } \\
\text { (Lele 2008d }\end{array}$ \\
\hline growing_weeks & 30 & $\begin{array}{l}\text { weeks in the growing season including initial, development, flowering, } \\
\text { and harvest phases (Kheira and Atta 2008, p. 5) }\end{array}$ \\
\hline harvest_per_yr & 1 & $\begin{array}{l}\text { assumes one harvest per year at given seed yield per hectare. } \\
\text { Represents the number of times seeds can be harvested per year based } \\
\text { on production of the Jatropha trees. Production is a function of rainfall, } \\
\text { irrigation, soil conditions, climate, and fertilization. Used to help calculate } \\
\text { total lifetime seed yield in the Jatropha plantation operation module } \\
\text { (Sarin 2008a) }\end{array}$ \\
\hline husk_energy_con & 15.5 & $\begin{array}{l}\text { MJ/kg, Gross energy content of Jatropha seed husks (dry matter) } \\
\text { (Reinhardt et al. 2008, Table 2-10) }\end{array}$ \\
\hline irr_years & 3 & $\begin{array}{l}\text { years, number of years irrigation is required. Sensitivity values of } 0 \text { years } \\
\text { for no irrigation and } 20 \text { years for full life time irrigation can be used. Used } \\
\text { in Jatropha Seeds Harvested from Plantation Module (Achten et al. } \\
2008, \text { p. 4) }\end{array}$ \\
\hline jatoil_extract & 63 & $\begin{array}{l}\text { MT/day, daily production of extracted oil in ecoinvent database, Used to } \\
\text { allocate infrastructure of oil extraction unit to each tonne of oil extracted, } \\
\text { Used to calculate "jatoil_ext_life" parameter that represents to the total } \\
\text { Jatropha oil extracted over the ecoinvent extraction plant life cycle } \\
\text { (ecoinvent 2.0, Description of Module "Oil mill/CH/l S") }\end{array}$ \\
\hline jatoil_life & 50 & $\begin{array}{l}\text { yrs, lifetime of oil extraction facility in ecoinvent database. Used to } \\
\text { allocate infrastructure of oil extraction unit to each tonne of oil extracted. } \\
\text { Used to calculate jatoil_ext_life parameter that represents to the total } \\
\text { Jatropha oil extracted over the ecoinvent extraction plant life cycle } \\
\text { (ecoinvent 2.0, Description of Module "Oil mill/CH/l S") }\end{array}$ \\
\hline jatropha_water & 6 & $\begin{array}{l}\text { liters per week, average consumption of water by Jatropha during } \\
\text { growing season (Kheira and Atta 2008, p. 5) }\end{array}$ \\
\hline $\mathrm{K} 2 \mathrm{O} \_f e r t$ req & 89 & $\begin{array}{l}\mathrm{kg} / \mathrm{ha}-\mathrm{yr}, \text { Reinhardt optimized scenario for fertilizer use on the plantation } \\
\text { (tree density 1,667). Adjusted as need to tree density being modeled. } \\
\text { Used in the Jatropha Seeds Harvested from Plantation module } \\
\text { (Reinhardt et al. 2008, Table 2-12) }\end{array}$ \\
\hline
\end{tabular}




\begin{tabular}{|c|c|c|}
\hline $\begin{array}{l}\text { Input Parameter } \\
\text { Name }\end{array}$ & Value & Description (Source) \\
\hline life_cycle_yr & 20 & $\begin{array}{l}\text { yrs, defines the lifetime of the study being analyzed. Base case } \\
\text { assumption of M. Whitaker. Used to calculate total Jatropha plantation } \\
\text { output and total gross tonne kilometers transported on rail system. } \\
\text { Sensitivity values of } 5 \text { years and } 50 \text { years can be used to check the } \\
\text { impact of shorter and longer analysis lifetimes. }\end{array}$ \\
\hline loco_gtk & $1 \mathrm{E}+08$ & $\begin{array}{l}\text { gross tonne kilometers/locomotive-yr (based on IR averaging } 480 \text { billion } \\
\text { GTK transported each year with } 4800 \text { locomotives) (Indian Railways } \\
2008, \text { p. } 17 \text { ) }\end{array}$ \\
\hline mat_KCL_app & 80 & $\begin{array}{l}\text { grams } \mathrm{KCl} / \text { tree/application for mature Jatropha plantation. Soil testing is } \\
\text { required to determine actual soil nutrient requirements. These values are } \\
\text { based on approximate fertilizer requirements assuming average soil } \\
\text { conditions. Used in Plantation Operation module to define fertilizer } \\
\text { requirement. Lele's numbers (Lele 2008a, p. 44). Sensitivity values of } \\
\text { half and double the fertilizer requirement can be used to test impact of } \\
\text { parameter. }\end{array}$ \\
\hline mat_KNit_app & 25 & $\begin{array}{l}\text { grams K Nitrate/tree/application for mature Jatropha plantation. Soil } \\
\text { testing is required to determine actual soil nutrient requirements. These } \\
\text { values are based on approximate fertilizer requirements assuming } \\
\text { average soil conditions. Used in Plantation Operation module to define } \\
\text { fertilizer requirement. Lele's numbers (Lele 2008a, p. 44). Sensitivity } \\
\text { values of half and double the fertilizer requirement can be used to test } \\
\text { impact of parameter. }\end{array}$ \\
\hline mat_SSP_app & 100 & $\begin{array}{l}\text { grams single super phosphate/tree/application for mature Jatropha } \\
\text { plantation. Soil testing is required to determine actual soil nutrient } \\
\text { requirements. These values are based on approximate fertilizer } \\
\text { requirements assuming average soil conditions. Used in Plantation } \\
\text { Operation module to define fertilizer requirement. Lele's numbers (Lele } \\
2008 \text { a, p. 44). Sensitivity values of half and double the fertilizer } \\
\text { requirement can be used to test impact of parameter. }\end{array}$ \\
\hline mat_urea_app & 150 & $\begin{array}{l}\text { grams urea/tree/application for mature Jatropha plantation. Soil testing is } \\
\text { required to determine actual soil nutrient requirements. These values are } \\
\text { based on approximate fertilizer requirements assuming average soil } \\
\text { conditions. Used in Plantation Operation module to define fertilizer } \\
\text { requirement. Lele's numbers (Lele 2008a, p. 44). Sensitivity values of } \\
\text { half and double the fertilizer requirement can be used to test impact of } \\
\text { parameter. }\end{array}$ \\
\hline mature_biomass & 8.5 & $\begin{array}{l}\mathrm{kg} \text { biomass/tree. IOC supplied estimate of biomass from pruning of } \\
\text { mature Jatropha trees (Sarin 2008d) }\end{array}$ \\
\hline meth_recycle & 0.5 & $\begin{array}{l}\text { Fraction of methanol that can be recycled during biodiesel production. } \\
\text { Assumes that about half of methanol is consumed during biodiesel } \\
\text { production process and that greater than } 99.9 \% \text { of non-consumed } \\
\text { methanol can be technically recovered (SRS Engineering 2009, p. 1) }\end{array}$ \\
\hline meth_switch & 0 & $\begin{array}{l}\text { Switch used to select recycling scenario for methanol. Set to "1" to model } \\
\text { methanol recycling, set to "0" to model biodiesel production without } \\
\text { methanol recycling. }\end{array}$ \\
\hline mode_switch & 1 & $\begin{array}{l}\text { Parameter switches the modeling scenario between the road and rail } \\
\text { sectors. Set to "1" for rail, set to "0" for road. }\end{array}$ \\
\hline N_fert_req & 81 & $\begin{array}{l}\mathrm{kg} / \mathrm{ha}-\mathrm{yr} \text {, Reinhardt optimized scenario for fertilizer use on the plantation } \\
\text { (tree density } 1,667 \text { ). Adjusted as need to tree density being modeled. } \\
\text { Used in the Jatropha Seeds Harvested from Plantation module } \\
\text { (Reinhardt et al. 2008, Table } 2-12 \text { ) }\end{array}$ \\
\hline
\end{tabular}




\begin{tabular}{|c|c|c|}
\hline $\begin{array}{l}\text { Input Parameter } \\
\text { Name }\end{array}$ & Value & Description (Source) \\
\hline N2O_release & 0.01 & $\begin{array}{l}\text { Fraction of nitrogen contained in fertilizer that is released to the air as } \\
\mathrm{N}_{2} \mathrm{O} \text {, fraction is on a mass basis ( } \mathrm{gN}_{2} \mathrm{O} / \mathrm{gN} \text { in fertilizer). } \\
\text { Intergovernmental Panel on Climate Change (2006) estimate in Table } \\
11.1 \text {. For sensitivity, low end of IPCC range }(0.003) \text { can be used. For } \\
\text { high end sensitivity, } 0.04 \text { can be used representing top down estimate of } \\
\mathrm{N}_{2} \mathrm{O} \text { release from newly fixed nitrogen by Crutzen et al. (2008) } \\
\text { Represents midpoint of 3-5\% (mass percent) range (Crutzen et al. 2008, } \\
\text { p. 390) }\end{array}$ \\
\hline oil_content & 0.35 & $\begin{array}{l}\text { Percent oil content of seed, weight oil/weight total seed. Average oil } \\
\text { content of dry seed on mass basis as identified by Achten et al. (2008). } \\
\text { IOC notes that oil content of seeds increase until year } 6 \text { and then } \\
\text { stabilize. Oil content of seeds identified as } 35-40 \% \text { by IOC. Indian } \\
\text { Planning Commission assumes } 35 \% \text { in their calculations. Used to } \\
\text { calculate oil recovery efficiency parameter (Achten et al. } 2008, \text { p. } 7 \text { ) }\end{array}$ \\
\hline oil_domestic & 3200 & $\begin{array}{l}\text { km, transport distance for domestic oil between Bombay High and } \\
\text { VIZAG per sea route. Estimated distance between Bombay High } \\
\text { offshore oil field and terminal at VIZAG. Used to calculate parameter } \\
\text { "crude_ocean trn" for impacts of transported crude oil to India in the } \\
\text { Crude Oil India module (World Port Source Web site 2008) }\end{array}$ \\
\hline oil_mid_east & 7000 & $\begin{array}{l}\mathrm{km} \text {, approximate distance traveled for transport of crude oil by tanker } \\
\text { from Middle East to Vizag. Used to measure the total impact of ocean oil } \\
\text { transport for India crude oil production (Distances.com 2008) }\end{array}$ \\
\hline oil_Nigeria & 14000 & $\begin{array}{l}\mathrm{km} \text {, approximate distance traveled for transport of crude oil by tanker } \\
\text { from Nigeria to Vizag (Distances.com 2008) }\end{array}$ \\
\hline oil_yield_red & 0 & $\begin{array}{l}\text { fractional parameter to reduce oil yield percentage from base case in } \\
\text { sensitivity analyses. Set to "0" for no reduction, "0.2" would represent a } \\
20 \% \text { reduction. }\end{array}$ \\
\hline P2O5_fert_req & 31 & $\begin{array}{l}\mathrm{kg} / \mathrm{ha}-\mathrm{yr} \text {, Reinhardt optimized scenario for fertilizer use on the plantation } \\
\text { (tree density } 1,667 \text { ). Adjusted as need to tree density being modeled. } \\
\text { Used in the Jatropha Seeds Harvested from Plantation module } \\
\text { (Reinhardt et al. 2008, Table 2-12) }\end{array}$ \\
\hline plant_manure & 4.5 & $\begin{array}{l}\mathrm{kg} \text { manure/planting hole Lele estimate for manure required at original } \\
\text { planting of tree. Used in Jatropha Planting Module (Lele 2008a, p. 39) }\end{array}$ \\
\hline plant_MOP & 16 & $\begin{array}{l}\text { grams of murate of potash (common name for } \mathrm{KCl} \text { )/planting hole. IOC } \\
\text { estimates of fertilizer requirements per planting hole, consistent with Lele } \\
\text { estimates in literature with literature values. Used in Jatropha Planting } \\
\text { Module (Lele 2008a, p. 39; Sarin 2008a) }\end{array}$ \\
\hline plant_SSP & 120 & $\begin{array}{l}\text { grams single super phosphate per planting hole. IOC estimates of } \\
\text { fertilizer requirements per planting hole, consistent with Lele estimates in } \\
\text { literature with literature values Used in Jatropha Planting Module (Lele } \\
\text { 2008a, p. 39; Sarin 2008a) }\end{array}$ \\
\hline plant_urea & 20 & $\begin{array}{l}\text { grams urea/planting hole (IOC estimate, comparable to Lele estimates). } \\
\text { IOC estimates of fertilizer requirements per planting hole, consistent with } \\
\text { Lele estimates in literature with literature values Used in Jatropha } \\
\text { Planting Module (Lele 2008a, p. 39; Sarin 2008a) }\end{array}$ \\
\hline plantation_elec & 2431620 & $\begin{array}{l}\text { kWh electricity/yr required to operate a } 10,000 \text { hectare plantation. Total } \\
\text { annual electricity requirement based on connected load and load factor } \\
\text { (based on } 300 \text { work days per year, } 3 \text { shifts per day). Inclusion is } \\
\text { considered conservative as may double count some fertilizing and } \\
\text { irrigation distribution impacts (Lele } 2008 \mathrm{~b} \text {, cell E431) }\end{array}$ \\
\hline plantation_tot & 50000 & hectares, to be split into 10,000 hectare units for management. 50,000 \\
\hline
\end{tabular}




\begin{tabular}{|c|c|c|}
\hline Input Parameter & Value & Description (Source) \\
\hline & & $\begin{array}{l}\text { hectares is the IOC estimated size of the proposed Jatropha plantation in } \\
\text { the Raipur district of Chhattisgarh. Used in all of the plantation modules } \\
\text { (Sarin 2008a) }\end{array}$ \\
\hline poly_eth_bag & 7 & $\begin{array}{l}\text { grams, weight of LLDPE bag for seedling cultivation. Unlikely to be } \\
\text { significant, sensitivity optional. Used to calculate amount of LLDPE } \\
\text { required as LLDPE case weight normalized to one bag and converted } \\
\text { from pounds to grams (Republic Bag Web site 2008) }\end{array}$ \\
\hline rail_pass_cons & 4.38 & $\begin{array}{l}\text { liters diesel/1000 GTK of passenger-rail transport (Indian Railways 2008, } \\
\text { p. 17) }\end{array}$ \\
\hline rail_switch & 1 & $\begin{array}{l}\text { Switch used to shift between analyzing freight transport and passenger } \\
\text { transport in the rail sector. "1" analyzes freight transport, "0" analyzes } \\
\text { passenger transport. }\end{array}$ \\
\hline reinhardt_dens & 1667 & $\begin{array}{l}\text { assumed trees/hectare for Reinhardt's calculations. Used to scale } \\
\text { Reinhardt's recommendations for fertilizer and diesel fuel to modeled } \\
\text { plantation tree density (Reinhardt et al. 2008, Table 2-12) }\end{array}$ \\
\hline required_rain & 2500 & $\begin{array}{l}\mathrm{mm} / \mathrm{yr} \text {, amount of rain required to avoid irrigation. The correlation } \\
\text { between rainfall and irrigation requirements is very poorly correlated in } \\
\text { the Jatropha literature (Prueksakorn and Gheewala 2008, p. 2) }\end{array}$ \\
\hline road_switch & 1 & $\begin{array}{l}\text { Switch used to shift between analyzing freight transport (trucks) and } \\
\text { passenger transport (buses) in the road sector. "1" analyzes trucks, "0" } \\
\text { analyzes buses. }\end{array}$ \\
\hline seed_cake_K & 0.1 & $\begin{array}{l}\text { fraction potassium of fertilizer replaced by seed cake These ratios can be } \\
\text { used to determine amount of chemical fertilizer offset if seed cake is } \\
\text { returned to field as a fertilizer substitute. No sensitivity values for the } \\
\text { fertilizer NPK ratio at this time. Used to determine avoided products in } \\
\text { the Jatropha Oil Extraction module (Prueksakorn and Gheewala 2008, p. } \\
\text { 3389) }\end{array}$ \\
\hline seed_cake_N & 0.4 & $\begin{array}{l}\text { fraction Nitrogen of fertilizer replaced by seed cake These ratios can be } \\
\text { used to determine amount of chemical fertilizer offset if seed cake is } \\
\text { returned to field as a fertilizer substitute. No sensitivity values for the } \\
\text { fertilizer NPK ratio at this time. Used to determine avoided products in } \\
\text { the Jatropha Oil Extraction module (Prueksakorn and Gheewala 2008, p. } \\
\text { 3389) }\end{array}$ \\
\hline seed_cake_P & 0.2 & $\begin{array}{l}\text { fraction phosphorus of fertilizer replaced by seed cake. These ratios can } \\
\text { be used to determine amount of chemical fertilizer offset if seed cake is } \\
\text { returned to field as a fertilizer substitute. No sensitivity values for the } \\
\text { fertilizer NPK ratio at this time. Used to determine avoided products in } \\
\text { the Jatropha Oil Extraction module (Prueksakorn and Gheewala 2008, p. } \\
\text { 3389) }\end{array}$ \\
\hline seed_cake_rep & 0.15 & $\begin{array}{l}\mathrm{kg} \text { of NPK (40:20:10) fertilizer replaced by } 1 \mathrm{~kg} \text { Jatropha seed cake. } \\
\text { These ratios can be used to determine amount of chemical fertilizer } \\
\text { offset if seed cake is returned to field as a fertilizer substitute. No } \\
\text { sensitivity values for the fertilizer NPK ratio at this time. Used to } \\
\text { determine avoided products in the Jatropha Oil Extraction module } \\
\text { (Prueksakorn and Gheewala 2008, p. 3389) }\end{array}$ \\
\hline seed_husk_yield & 1429 & $\begin{array}{l}\mathrm{kg} \text { sun dried husk/ha-yr. Reinhardt estimate at } 9 \% \text { water content, } \\
\text { optimized scenario (Reinhardt et al. 2008, Table } 2-2 \text { ) }\end{array}$ \\
\hline seed_survive & 0.8 & $\begin{array}{l}\text { Fraction of planted seedlings that survive. Assumed survival rate of } \\
\text { seedlings grown in nursery for } 4-6 \text { months and transplanted to plantation. } \\
\text { Does not include potential for disease outbreaks. Used in calculating } \\
\text { seedling requirement in the Jatropha Plantation, Planted, module (Lele }\end{array}$ \\
\hline
\end{tabular}




\begin{tabular}{|c|c|c|}
\hline \multirow{2}{*}{$\begin{array}{l}\text { Input Parameter } \\
\text { Name }\end{array}$} & Value & Description (Source) \\
\hline & & 2008a, p. 53; Renewable Energy U.K. 2007, p. 1) \\
\hline seed_tran_dist & 50 & $\begin{array}{l}\mathrm{km} \text {, transport distance for Jatropha seeds, assumed distance between } \\
\text { plantation and processing facility, seed transport via truck, IOC stated } \\
\text { that plantation distance from processing in Raipur would be small. Used } \\
\text { in Oil Extraction module to determine transport distance for seeds (Sarin } \\
\text { 2008c) }\end{array}$ \\
\hline seed_yield_red & 0 & $\begin{array}{l}\text { Fractional parameter to reduce seed yield per tree from base case in } \\
\text { sensitivity analyses. Set to "0" for no reduction, " } 0.2 \text { " would represent a } \\
20 \% \text { reduction. }\end{array}$ \\
\hline seed_yield_tree & 1.5 & $\begin{array}{l}\text { Kilograms dry seed/tree, assumed seed yield based on India Planning } \\
\text { Commission (Planning Commission) estimates IPC assumption for } \\
\text { calculation in report based on average conditions Used to determine } \\
\text { seed yield in Plantation Operation module (Planning Commission 2003, } \\
\text { p. 174) }\end{array}$ \\
\hline solv_extract_n & 0.91 & $\begin{array}{l}\text { Fraction, extraction efficiency for solvent extraction, weight oil } \\
\text { extracted/weight oil available in seed, IPC assumption for calculation in } \\
\text { report based on average conditions. Used to calculate parameter } \\
\text { "oil_recov_eff" to determine amount of oil extracted from the oil content } \\
\text { of the seeds (Planning Commission 2003, p. 174) }\end{array}$ \\
\hline solvent_elec & 55 & $\begin{array}{l}\text { kWh electricity/tonne of seed required for continuous solvent extraction, } \\
\text { Data represent average operations of a continuous solvent extraction } \\
\text { unit. Used in Jatropha Oil Extraction module (Adriaans 2006, p. 7, Table } \\
\text { 1) }\end{array}$ \\
\hline solvent_hexane & 4 & $\begin{array}{l}\mathrm{kg} \text { hexane-n/tonne of seed required for continuous solvent extraction, } \\
\text { Data represent average operations of a continuous solvent extraction } \\
\text { unit. Used in Jatropha Oil Extraction module (Adriaans 2006, p. 7, Table } \\
\text { 1) }\end{array}$ \\
\hline solvent_recycle & 0.99 & $\begin{array}{l}\text { Mass fraction of hexane recycled during solvent extraction, Data } \\
\text { represent average operations of a continuous solvent extraction unit. } \\
\text { Used in Jatropha Oil Extraction module (Adriaans 2006, p. 7, Table 1) }\end{array}$ \\
\hline solvent_steam & 280 & $\begin{array}{l}\mathrm{kg} \text { steam per tonne of seed required for continuous solvent extraction, } \\
\text { Data represent average operations of a continuous solvent extraction } \\
\text { unit. Used in Jatropha Oil Extraction module (Adriaans 2006, p. 7, Table } \\
\text { 1) }\end{array}$ \\
\hline solvent_trans & 0 & $\begin{array}{l}\text { ton-km transport for oil extracted at solvent extraction facility to reach } \\
\text { biodiesel transesterification facility. Assumption is that the oil extraction } \\
\text { and transesterification units are co-located, Assumption is that the oil } \\
\text { extraction and transesterification units are co-located, Used in biodiesel } \\
\text { production module (Sarin 2008c) }\end{array}$ \\
\hline solvent_water & 12 & $\begin{array}{l}\mathrm{m}^{\wedge} 3 \text { water/tonne of seed required for continuous solvent extraction } \\
\text { (consumed and discharged to sewer), Data represent average } \\
\text { operations of a continuous solvent extraction unit. Used in Jatropha Oil } \\
\text { Extraction module (Adriaans } 2006, \text { p. } 7 \text {, Table } 1 \text { ) }\end{array}$ \\
\hline spec_ener_leaf & 3624 & $\begin{array}{l}\mathrm{kJ} / \mathrm{kg} \text {, Gross specific energy content of Jatropha biomass (Nivitchanyong } \\
2007 \text {, slide 22) }\end{array}$ \\
\hline spec_ener_stem & 3932 & $\begin{array}{l}\mathrm{kJ} / \mathrm{kg} \text {, Gross specific energy content of Jatropha biomass (Nivitchanyong } \\
2007 \text {, slide 22) }\end{array}$ \\
\hline spec_grav_biod & 0.88 & $\begin{array}{l}\mathrm{kg} / \mathrm{L} \text {, Used to calculate fuel use requirements for the trains and perform } \\
\text { volume/mass conversions (Planning Commission 2003, p. 77; Gubler } \\
2006 \text {, p. 205.0020E) }\end{array}$ \\
\hline
\end{tabular}




\begin{tabular}{|c|c|c|}
\hline $\begin{array}{l}\text { Input Parameter } \\
\text { Name }\end{array}$ & Value & Description (Source) \\
\hline spec_grav_dies & 0.84 & $\begin{array}{l}\mathrm{kg} / \mathrm{L} \text {, Used to calculate fuel use requirements for the trains and perform } \\
\text { volume/mass conversions (Planning Commission 2003, p. 77; Gubler } \\
2006, \text { p. 205.0020E) }\end{array}$ \\
\hline transest_eff & 0.95 & $\begin{array}{l}\text { conversion efficiency of Jatropha oil to biodiesel, Assumes 100,000 } \\
\text { tonnes/year plant capacity, Used in the Transesterification module } \\
\text { (Planning Commission 2003, Table Annexure X) }\end{array}$ \\
\hline transest_elect & 38 & $\begin{array}{l}\text { kWh electricity required/tonne of biodiesel produced. Assumes 100,000 } \\
\text { tonnes/year plant capacity, Used in the Transesterification module. } \\
\text { Includes electricity for glycerol purification (Planning Commission 2003; } \\
\text { Lele 2008d) }\end{array}$ \\
\hline transest_KOH & 18 & $\begin{array}{l}\mathrm{kg} \mathrm{KOH} \text { required/tonne of biodiesel produced, Assumes } 100,000 \\
\text { tonnes/year plant capacity, Used in the Transesterification module } \\
\text { (Planning Commission 2003, Table Annexure X) }\end{array}$ \\
\hline transest_meth & 110 & $\begin{array}{l}\mathrm{kg} \text { methanol required/tonne of biodiesel produced, Assumes } 100,000 \\
\text { tonnes/year plant capacity, Used in the Transesterification module } \\
\text { (Planning Commission 2003, Table Annexure X) }\end{array}$ \\
\hline transest_minacd & 6 & $\begin{array}{l}\mathrm{kg} \text { mineral acid required/tonne of biodiesel produced (assume sulfuric } \\
\text { acid as the base case), Assumes 100,000 tonnes/year plant capacity, } \\
\text { Used in the Transesterification module (Planning Commission 2003, } \\
\text { Table Annexure X) }\end{array}$ \\
\hline transest_steam & 851 & $\begin{array}{l}\mathrm{kg} \text { steam required/tonne of biodiesel produced, Assumes 100,000 } \\
\text { tonnes/year plant capacity, Used in the Transesterification module, } \\
\text { includes steam for glycerol purification (Planning Commission 2003; Lele } \\
2008 \mathrm{~d} \text { ) }\end{array}$ \\
\hline tree_density & 2500 & $\begin{array}{l}\text { trees/hectare, initial plantation density of Jatropha trees, IPC assumption } \\
\text { for calculation in report based on average conditions, Used to determine } \\
\text { seed yield in Plantation Operation module (Planning Commission 2003, } \\
\text { p. 174) }\end{array}$ \\
\hline truck_long_fuel & 12.8 & $\begin{array}{l}\text { Liters diesel consumed per } 1,000 \text { gross tonne kilometers transported at } \\
100 \% \text { utilization (European Automobile Manufacturers Association } 2009 \text {, } \\
\text { p. 6) }\end{array}$ \\
\hline truck_switch & 1 & $\begin{array}{l}\text { Switches the modeled truck transport between long distance trucks (26- } \\
60 \text { tonne capacity) to urban distribution trucks ( } 7.5-18 \text { tonne capacity). } \\
\text { "1" indicates long distance trucks, "0" indicates urban trucks }\end{array}$ \\
\hline truck_urb_fuel & 28.8 & $\begin{array}{l}\text { Liters diesel consumed per } 1,000 \text { gross tonne kilometers transported at } \\
100 \% \text { utilization (European Automobile Manufacturers Association 2009, } \\
\text { p. 6) }\end{array}$ \\
\hline vizag_elec & 31.91 & $\begin{array}{l}\mathrm{kWh} / \text { tonne of crude oil processed, specific electricity consumption of the } \\
\text { VIZAG refinery. Substituted for the electricity consumption in the Indian } \\
\text { copy of the default ecoinvent Diesel at refinery module (Hindustan } \\
\text { Petroleum Corporation Limited 2008) }\end{array}$ \\
\hline vizag_therm & 0.37 & $\begin{array}{l}\text { Million kcal/tonne of crude oil processed, specific thermal energy } \\
\text { consumption for the VIZAG refinery. Used to define the amount of fuel oil } \\
\text { burned in the Indian copy of the default ecoinvent Diesel, at refinery } \\
\text { module (Hindustan Petroleum Corporation Limited 2008) }\end{array}$ \\
\hline water_req_met & 1 & $\begin{array}{l}\text { Fraction of annual water requirement met. According to Kheira and Atta } \\
\text { (2008), water requirement can be considered to be equal to the potential } \\
\text { evapotranspiration (ETp). Water requirement is displayed with the } \\
\text { calculated parameter "annual_jat_h2o" and is equal to } \\
\text { "jatropha_water*growing_weeks." }\end{array}$ \\
\hline
\end{tabular}




\begin{tabular}{lll}
\hline $\begin{array}{l}\text { Input Parameter } \\
\text { Name }\end{array}$ & Value & Description (Source) \\
\cline { 2 - 3 } yr_1_biomass & 2.5 & $\begin{array}{l}\text { kg biomass/tree, IOC supplied estimate of first year biomass yield from } \\
\text { pruning (Sarin 2008c) }\end{array}$ \\
yr_2_biomass & 4.5 & $\begin{array}{l}\text { kg biomass/tree, IOC supplied estimate of second year biomass yield } \\
\text { from pruning (Sarin 2008c) }\end{array}$ \\
\hline
\end{tabular}


Table A-2. Calculated input parameters that have values determined by formulas based on other parameters

\begin{tabular}{|c|c|c|}
\hline Name & Formula & Description \\
\hline annual_jat_h2o & $\begin{array}{l}\text { jatropha_water*growing_weeks* } \\
\text { tree_density/1000 }\end{array}$ & $\begin{array}{l}\mathrm{m}^{\wedge} 3 \text { water/ha-yr, total water required by one } \\
\text { hectare of the Jatropha plantation for a year; } \\
\text { number can be substituted with potential } \\
\text { evapotranspiration if known. }\end{array}$ \\
\hline bio_blend_sg & $\begin{array}{l}\text { spec_grav_dies*(1- } \\
\text { biodiesel_blend)+ } \\
\text { spec_grav_biod*biodiesel_blend }\end{array}$ & $\mathrm{kg} / \mathrm{liter}$, specific gravity of blended fuel \\
\hline bio_fuel_con & $\begin{array}{l}\text { (1-biodiesel_eff* } \\
\text { biodiesel_blend)*rail_fuel_con }^{*}\end{array}$ & $\begin{array}{l}\text { Liters blended biodiesel/1000 gross tonne } \\
\text { kilometers }\end{array}$ \\
\hline bio_plant_piece & 1/bio_prod_life & $\begin{array}{l}\text { Piece of a biodiesel transesterification plant } \\
\text { allocated to each tonne of biodiesel produced } \\
\text { based on ecoinvent numbers; this value is } \\
\text { used to represent the infrastructure } \\
\text { contribution of the transesterification facility in } \\
\text { the Indian case study. }\end{array}$ \\
\hline bio_prod_life & bio_plant_life*bio_plant_prod*365 & $\begin{array}{l}\text { Lifetime biodiesel fuel production assumed in } \\
\text { ecoinvent inventory calculation }\end{array}$ \\
\hline bus_bio_cons & $\begin{array}{l}\text { (1-biodiesel_blendbiodiesel_eff) } \\
{ }^{*} \text { bus_dieselºio_blend_sg }\end{array}$ & $\begin{array}{l}\mathrm{kg} \text { biodiesel blend consumed } / 1000 \text { gross } \\
\text { tonne kilometer transported via bus }\end{array}$ \\
\hline bus_diesel & $\begin{array}{l}\text { 1/(bus_dies_cons*bus_weight)* } \\
1000\end{array}$ & $\begin{array}{l}\text { Liters diesel consumed/1000 gross tonne } \\
\text { kilometer transported via bus }\end{array}$ \\
\hline cal_val_blend & $\begin{array}{l}\text { cal_val_bio*biodiesel_blend+ } \\
\text { cal_val_diesel*(1-biodiesel_blend) }\end{array}$ & $\begin{array}{l}\mathrm{kJ} / \mathrm{kg} \text {, calorific value of blended fuel delivered } \\
\text { to vehicles }\end{array}$ \\
\hline CO2_biodiesel & CO2_bio/spec_grav_biod & $\begin{array}{l}\mathrm{CO}_{2} \text { emissions for biodiesel on a } \mathrm{kg} \mathrm{CO}_{2} / \mathrm{kg} \\
\text { biodiesel basis }\end{array}$ \\
\hline CO2_diesel & CO2_dies/spec_grav_dies & $\begin{array}{l}\mathrm{CO}_{2} \text { emissions for diesel on a } \mathrm{kg} \mathrm{CO} / \mathrm{kg} \text { diesel } \\
\text { basis }\end{array}$ \\
\hline crude_bombay & $(1 \text {-crude_foreign })^{*}$ crude_offshore & $\begin{array}{l}\text { fraction of total crude oil from domestic fields } \\
\text { (Bombay High) }\end{array}$ \\
\hline $\begin{array}{l}\text { crude_mid_east } \\
\text { crude_Nigeria }\end{array}$ & $\begin{array}{l}\text { crude_foreign*frac_mid_east } \\
\text { crude_foreign*(1-frac_mid_east) }\end{array}$ & $\begin{array}{l}\text { fraction of total crude oil from Middle East } \\
\text { fraction of total crude oil from Nigeria }\end{array}$ \\
\hline crude_ocean_trn & $\begin{array}{l}\text { crude_Nigeria*oil_Nigeria+crude_} \\
\text { mid_east*oil_mid_east+ } \\
\text { crude_bombay*oil_domestic }\end{array}$ & $\begin{array}{l}\text { t-km, tonne kilometer of oil tanker transport } \\
\text { required to deliver } 1 \text { tonne of total crude oil to } \\
\text { the Indian coastal oil terminal at } \\
\text { Visakhapatnam }\end{array}$ \\
\hline frac_leaf & 1-frac_stem & Mass fraction of biomass that is leaves \\
\hline husk_tot_mass & $\begin{array}{l}\text { seed_husk_yield*plantation_tot* } \\
\text { harvest_per_yr*life_cycle_yr }\end{array}$ & kg seed husks over plantation lifetime \\
\hline jatoil_ext_life & jatoil_extract*jatoil_life*365 & $\begin{array}{l}\text { Lifetime oil extraction assumed in ecoinvent } \\
\text { inventory calculation }\end{array}$ \\
\hline jatoil_plnt_pce & 1/jatoil_ext_life & $\begin{array}{l}\text { Piece of a biodiesel transesterification plant } \\
\text { allocated to each tonne of oil extracted based } \\
\text { on ecoinvent numbers; this value is used to } \\
\text { represent the infrastructure contribution of the } \\
\text { solvent extraction facility in the Indian case } \\
\text { study. }\end{array}$ \\
\hline jatoil_required & 1/transest_eff & $\begin{array}{l}\mathrm{kg} \text { Jatropha oil required to produce } 1 \mathrm{~kg} \text { of } \\
\text { biodiesel }\end{array}$ \\
\hline life_biomass_el & $\begin{array}{l}\text { (life_biomass_en+life_husk_en })^{*} \\
0.000278^{*} \text { bio_elec_eff }\end{array}$ & $\begin{array}{l}\mathrm{kWh} \text { electricity offset over lifetime (converted } \\
\text { from kilojoules), includes combustion of } \\
\text { plantation biomass gathered over lifetime of }\end{array}$ \\
\hline
\end{tabular}




\begin{tabular}{|c|c|c|}
\hline Name & Formula & Description \\
\hline & & plantation including leaves, stems, fruit husks \\
\hline life_biomass_en & $\begin{array}{l}\text { life_biomass_to* } \\
\text { (frac_stem*spec_ener_stem+ } \\
\text { frac_leaf*spec_ener_leaf)/1000 }\end{array}$ & MJ leaf and stem energy \\
\hline life_biomass_pl & $\begin{array}{l}\text { yr_1_biomass+yr_2_biomass+ } \\
\text { (mature_biomass }{ }^{\star}(\text { life_cycle_yr2)) }\end{array}$ & Total kg biomass/plant over plantation lifetime \\
\hline life_biomass_to & $\begin{array}{l}\text { life_biomass_pl*tree_density* } \\
\text { plantation_tot }\end{array}$ & $\begin{array}{l}\mathrm{kg} \text {, total biomass produced on plantation over } \\
\text { lifetime }\end{array}$ \\
\hline life_husk_en & husk_tot_mass*husk_energy_con & MJ husk energy \\
\hline loco_bio_fuel & bio_fuel_con*bio_blend_sg & $\begin{array}{l}\mathrm{kg} \text { biodiesel blend used/1000 gross tonne } \\
\text { kilometer transported }\end{array}$ \\
\hline loco_life_gtk & loco_gtk*life_cycle_yr & $\begin{array}{l}\text { Lifetime gross tonne kilometer analyzed in the } \\
\text { study }\end{array}$ \\
\hline locomotive_CO2 & $\begin{array}{l}\text { CO2_diesel* } \\
\text { (1-biodiesel_blend)+ } \\
\text { CO2_biodiesel*biodiesel_blend }\end{array}$ & $\begin{array}{l}\text { ( } \mathrm{kg} \mathrm{CO}_{2} / \mathrm{kg} \text { fuel) Adjusted } \mathrm{CO}_{2} \text { emission factor } \\
\text { for the locomotive based on the biodiesel } \\
\text { blend being used }\end{array}$ \\
\hline N2O_release_ioc & $\begin{array}{l}\text { N2O_release }{ }^{*} \\
\text { (1-fert_switch) }{ }^{*} \text { urea_tot_lele }\end{array}$ & $\mathrm{kg} \mathrm{N} \mathrm{N}_{2} \mathrm{O}$ release under IOC fertilizer scenario \\
\hline N2O_release_rei & $\begin{array}{l}\text { N2O_release*fert_switch }{ }^{*} \\
\text { (N_fert_req*iantation_tot* } \\
\text { life_cycle_yr) }\end{array}$ & $\mathrm{kg} \mathrm{N}_{2} \mathrm{O}$ release in Reinhardt fertilizer scenario \\
\hline N2O_volatized & $\begin{array}{l}\mathrm{N} 2 \mathrm{O} \text { _release_rei+ } \\
\mathrm{N} 2 \mathrm{O} \text { release_ioc }\end{array}$ & $\begin{array}{l}\mathrm{kg} \mathrm{N} \mathrm{N}_{2} \mathrm{O} \text { volatized from } \mathrm{N} \text { fertilizer over } \\
\text { plantation lifetime }\end{array}$ \\
\hline oil_recov_eff & $\begin{array}{l}\text { (1-oil_yield_red })^{*} \text { oil_content }{ }^{*} \\
\text { solv_extract_n }\end{array}$ & $\begin{array}{l}\text { Weight of oil that is available and } \\
\text { recovered/total weight of seed }\end{array}$ \\
\hline rail_fuel_con & $\begin{array}{l}\text { rail_switch*diesel_fuel_con+ } \\
\text { (1-rail_switch)*rail_pass_cons }\end{array}$ & $\begin{array}{l}\text { Liters diesel/ } 1000 \mathrm{GTK} \text { of rail transport (freight } \\
\text { or passenger depending on switch). }\end{array}$ \\
\hline rainfall_def & required_rain-annual_rain & $\begin{array}{l}\mathrm{mm} / \mathrm{yr} \text {, calculated rainfall deficit for } \\
\text { determining irrigation requirements }\end{array}$ \\
\hline req_irrigation & $\begin{array}{l}\text { annual_jat_h20*water_req_met* } \\
\text { frac_met_irr }\end{array}$ & $m^{\wedge} 3$ irrigation water required per hectare-yr \\
\hline road_life_gtk & loco_life_gtk & $\begin{array}{l}\text { Lifetime gross tonne kilometer analyzed in this } \\
\text { study, set to same as locomotive life GTK for } \\
\text { comparison purposes }\end{array}$ \\
\hline seed_yield_hect & seed_yield_tree*tree_density & $\begin{array}{l}\text { Kilograms dry seed expected per hectare } \\
\text { based on tree density and seed yield per tree }\end{array}$ \\
\hline seedling_plant & tree_density/seed_survive & $\begin{array}{l}\text { Total trees required to be planted to achieve } \\
\text { desired mature tree density based on seedling } \\
\text { survival rate }\end{array}$ \\
\hline solvent_req & $\begin{array}{l}(1 \text {-solvent_recycle)* } \\
\text { solvent_hexane }\end{array}$ & $\begin{array}{l}\mathrm{kg} \text { hexane required to be replenished } / \mathrm{kg} \text { seeds } \\
\text { processed }\end{array}$ \\
\hline truck_bio_cons & $\begin{array}{l}\text { (1-biodiesel_blend*biodiesel_eff)* } \\
\text { truck_fuel_cons*bio_blend_sg }\end{array}$ & $\begin{array}{l}\mathrm{kg} \text { biodiesel blend consumed } / 1000 \text { gross } \\
\text { tonne kilometer transported via truck }\end{array}$ \\
\hline truck_CO2 & locomotive_CO2 & $\begin{array}{l}\mathrm{kg} \mathrm{CO} / \mathrm{kg} \text { fuel, assumes that } \mathrm{CO}_{2} \text { emissions } \\
\text { for biodiesel blends in trucks and rail will be } \\
\text { the same. Methane and NOx emissions for rail } \\
\text { and truck transport are not currently included. }\end{array}$ \\
\hline truck_fuel_cons & $\begin{array}{l}\text { (truck_switch*truck_long_fuel+ } \\
\text { (1-truck_switch)*truck_urb_fuel) }\end{array}$ & $\begin{array}{l}\text { Liters diesel consumed/1000 gross tonne } \\
\text { kilometer transported via truck }\end{array}$ \\
\hline urea_tot_lele & $\begin{array}{l}\text { mat_urea_app*tree_density* } \\
\text { fert_app_num*life_cycle_yr } \\
\text { plantation_tot } / 1000\end{array}$ & $\begin{array}{l}\mathrm{kg} \text { urea as } \mathrm{N} \text { required under Lele IOC fertilizer } \\
\text { scenario }\end{array}$ \\
\hline
\end{tabular}


Table A-3. India Electricity Generation Custom Module

\begin{tabular}{|c|c|c|c|}
\hline Module Flows* & $\begin{array}{l}\text { Input Value } \\
\text { or Variable }\end{array}$ & Units & Comments \\
\hline \multicolumn{4}{|l|}{ Products } \\
\hline Indian Electricity Generated & 1 & kWh & \\
\hline \multicolumn{4}{|l|}{ Avoided Products } \\
\hline \multicolumn{4}{|l|}{ Resources } \\
\hline \multicolumn{4}{|l|}{ Materials/Fuels } \\
\hline \multicolumn{4}{|l|}{ Electricity/heat } \\
\hline $\begin{array}{l}\text { Electricity, hard coal, at power } \\
\text { plant/UCTE S }\end{array}$ & elec_gen_coal & $\mathrm{kWh}$ & Fraction of a kWh generated by coal \\
\hline $\begin{array}{l}\text { Electricity, natural gas, at power } \\
\text { plant/UCTE S }\end{array}$ & elec_gen_ng & $\mathrm{kWh}$ & $\begin{array}{l}\text { Fraction of a kWh generated by } \\
\text { natural gas }\end{array}$ \\
\hline Electricity hydropower in UCPTE S & elec_gen_hydro & $\mathrm{kWh}$ & $\begin{array}{l}\text { Fraction of a kWh generated by hydro } \\
\text { (based on European average) }\end{array}$ \\
\hline $\begin{array}{l}\text { Electricity, nuclear, at power } \\
\text { plant/UCTE S }\end{array}$ & elec_gen_nuclea & $\mathrm{kWh}$ & $\begin{array}{l}\text { Fraction of a kWh generated by } \\
\text { nuclear power }\end{array}$ \\
\hline Electricity, at wind power plant/RER S & elec_gen_renew/2 & $\mathrm{kWh}$ & $\begin{array}{l}\text { Fraction of a kWh generated by wind } \\
\text { power (fraction of renewable energy } \\
\text { by technology not specified, assuming } \\
50 \% \text { of renewable wind, } 50 \% \text { solar) }\end{array}$ \\
\hline $\begin{array}{l}\text { Electricity, production mix } \\
\text { photovoltaic, at plant/US S }\end{array}$ & elec_gen_renew/2 & $\mathrm{kWh}$ & $\begin{array}{l}\text { Fraction of a kWh generated by } \\
\text { photovoltaics (fraction of renewable } \\
\text { energy by technology not specified, } \\
\text { assuming } 50 \% \text { of renewable wind, } \\
50 \% \text { solar) }\end{array}$ \\
\hline \multicolumn{4}{|l|}{ Emissions to air } \\
\hline \multicolumn{4}{|l|}{ Emissions to water } \\
\hline Emissions to soil & & & \\
\hline
\end{tabular}

* Drawn from ecoinvent 2.0 or other custom modules 
Table A-4. Indian Electricity Delivered Custom Module

\begin{tabular}{|c|c|c|c|}
\hline Module Flows* & $\begin{array}{l}\text { Input Value } \\
\text { or Variable }\end{array}$ & Units & Comments \\
\hline \multicolumn{4}{|l|}{ Products } \\
\hline Indian Electricity Delivered & 1 & kWh & \\
\hline \multicolumn{4}{|l|}{ Avoided Products } \\
\hline \multicolumn{4}{|l|}{ Resources } \\
\hline \multicolumn{4}{|l|}{ Materials/Fuels } \\
\hline \multicolumn{4}{|l|}{ Electricity/heat } \\
\hline Indian Electricity Generated & 1/(1-elec_TD_loss) & kWh & $\begin{array}{l}\text { Amount of electricity required to be } \\
\text { generated in order to deliver } 1 \mathrm{kWh} \text { to the } \\
\text { user on average }\end{array}$ \\
\hline Infra electricity LV use UCPTE S & 1 & $\mathrm{kWh}$ & $\begin{array}{l}\text { Inclusion of impacts from transmission } \\
\text { and distribution infrastructure for low } \\
\text { voltage electricity delivery }\end{array}$ \\
\hline \multicolumn{4}{|l|}{ Emissions to air } \\
\hline \multicolumn{4}{|l|}{ Emissions to water } \\
\hline Emissions to soil & & & \\
\hline
\end{tabular}

* Drawn from ecoinvent 2.0 or other custom modules

Table A-5. Jatropha Seedling for Planting Custom Module

\begin{tabular}{|c|c|c|c|}
\hline Module Flows* & $\begin{array}{l}\text { Input Value } \\
\text { or Variable }\end{array}$ & Units & Comments \\
\hline \multicolumn{4}{|l|}{ Products } \\
\hline Jatropha Seedling for Planting & 1 & $\mathrm{p}$ & $\begin{array}{l}\text { Seedling from nursery called by Jatropha } \\
\text { planting module for the initial } \\
\text { establishment of the plantation }\end{array}$ \\
\hline \multicolumn{4}{|l|}{ Avoided Products } \\
\hline \multicolumn{4}{|l|}{ Resources } \\
\hline \multicolumn{4}{|c|}{ Materials/Fuels } \\
\hline $\begin{array}{l}\text { Polyethylene, LLDPE, granulate, } \\
\text { at plant/RER S }\end{array}$ & poly_eth_bag & $g$ & $\begin{array}{l}\text { Limited data are available on the energy } \\
\text { and water requirements for growing } \\
\text { Jatropha seedlings at a nursery. This } \\
\text { parameter represents the polyethylene } \\
\text { bag that is used to grow each seedling. }\end{array}$ \\
\hline \multicolumn{4}{|l|}{ Electricity/heat } \\
\hline \multicolumn{4}{|l|}{ Emissions to air } \\
\hline \multicolumn{4}{|l|}{ Emissions to water } \\
\hline Emissions to soil & & & \\
\hline
\end{tabular}

* Drawn from ecoinvent 2.0 or other custom modules 
Table A-6. Jatropha Plantation, Planted, India Custom Module

\begin{tabular}{|c|c|c|c|}
\hline Module Flows* & $\begin{array}{l}\text { Input Value } \\
\text { or Variable }\end{array}$ & Units & Comments \\
\hline \multicolumn{4}{|l|}{ Products } \\
\hline $\begin{array}{l}\text { Jatropha Plantation, } \\
\text { Planted } \mathrm{Ha} \text {, India }\end{array}$ & 1 & ha & Jatropha Plantation, Planted $\mathrm{Ha}$, India \\
\hline \multicolumn{4}{|l|}{ Avoided Products } \\
\hline \multicolumn{4}{|l|}{ Resources } \\
\hline \multicolumn{4}{|c|}{ Materials/Fuels } \\
\hline $\begin{array}{l}\text { Jatropha Seedling for } \\
\text { Planting }\end{array}$ & seedling_plant & p & $\begin{array}{l}\text { Number of seedlings planted is adjusted } \\
\text { to account for the expected survival rate. }\end{array}$ \\
\hline $\begin{array}{l}\text { Urea, as } \mathrm{N} \text {, at regional } \\
\text { storehouse/RER } U\end{array}$ & $\begin{array}{l}\text { seedling_plant }{ }^{*} \text { plant_urea/ } \\
2.17 / 1000\end{array}$ & $\mathrm{~kg}$ & $\begin{array}{l}\text { Urea required to plant one hectare; } \\
\text { inputs per hole dividing by } 2.17 \text { because } \\
\text { ecoinvent process produces } 1 \mathrm{~kg} \mathrm{~N} \text { which } \\
\text { requires } 2.17 \mathrm{~kg} \text { urea; assumes Urea } \\
\text { with } \mathrm{N} \text { content of } 46 \% \text {. }\end{array}$ \\
\hline $\begin{array}{l}\text { Potassium chloride, } \\
\text { as } \mathrm{K}_{2} \mathrm{O} \text {, at regional } \\
\text { storehouse/RER U }\end{array}$ & $\begin{array}{l}\text { seedling_plant }{ }^{*} \text { plant_MOP/ } \\
1.67 / 1000\end{array}$ & $\mathrm{~kg}$ & $\begin{array}{l}\text { murate of potash (which was specified by } \\
\text { the } \mathrm{IOC} \text { to provide } \mathrm{K} \text { fertilizer) is the } \\
\text { common name for potassium chloride; } \\
\text { inputs per hole; dividing by } 1.67 \text { because } \\
\text { ecoinvent process produces } 1 \mathrm{~kg} \mathrm{~K} \mathrm{~K}_{2} \mathrm{O} \text {, } \\
\text { which requires } 1.67 \mathrm{~kg} \mathrm{KCl} \text {. Assumes } \\
\mathrm{KCL} \text { with } \mathrm{K}_{2} \mathrm{O} \text { content of } 60 \% \text {. }\end{array}$ \\
\hline $\begin{array}{l}\text { Single } \\
\text { superphosphate, as } \\
\mathrm{P}_{2} \mathrm{O}_{5} \text {, at regional } \\
\text { storehouse/RER U }\end{array}$ & $\begin{array}{l}\text { seedling_plant*plant_SSP/ } \\
4.76 / 1000\end{array}$ & $\mathrm{~kg}$ & $\begin{array}{l}\text { Single super phosphate required to plant } \\
\text { one hectare; inputs per hole dividing by } \\
4.76 \text { because ecoinvent process } \\
\text { produces } 1 \mathrm{~kg} \mathrm{P}_{2} \mathrm{O}_{5} \text {, which requires } 4.76 \\
\mathrm{~kg} \mathrm{SSP} \text {. Assumes SSP with } \mathrm{P}_{2} \mathrm{O}_{5} \text { content } \\
\text { of } 21 \%\end{array}$ \\
\hline $\begin{array}{l}\text { Poultry manure, dried, } \\
\text { at regional } \\
\text { storehouse/CH U }\end{array}$ & seedling_plant*plant_manure & $\mathrm{kg}$ & $\begin{array}{l}\text { Manure may be processed less than this } \\
\text { module indicates in the Indian context. }\end{array}$ \\
\hline Irrigating/ha/CH U & 1 & ha & $\begin{array}{l}\text { General module used to substitute for } \\
\text { unknown irrigation water requirement of } \\
\text { the newly planted field }\end{array}$ \\
\hline $\begin{array}{l}\text { Tillage, ploughing/CH } \\
\cup\end{array}$ & 1 & ha & $\begin{array}{l}\text { Used to represent energy required to } \\
\text { plough the field to clear prior to planting; } \\
\text { individual holes dug and planted using } \\
\text { manpower; fertilizer applied by hand to } \\
\text { each hole in initial establishment }\end{array}$ \\
\hline \multicolumn{4}{|l|}{ Electricity/heat } \\
\hline \multicolumn{4}{|l|}{ Emissions to air } \\
\hline \multicolumn{4}{|l|}{ Emissions to water } \\
\hline Emissions to soil & & & \\
\hline
\end{tabular}

* Drawn from ecoinvent 2.0 or other custom modules 
Table A-7. Jatropha Seeds Harvested from Plantation Custom Module

\begin{tabular}{|c|c|c|c|}
\hline Module Flows* & $\begin{array}{l}\text { Input Value } \\
\text { or Variable }\end{array}$ & Units & Comments \\
\hline \multicolumn{4}{|l|}{ Products } \\
\hline $\begin{array}{l}\text { Jatropha Seeds } \\
\text { Harvested from } \\
\text { Plantation }\end{array}$ & $\begin{array}{l}(1- \\
\text { seed_yield_red })^{*} \text { seed_yield } \\
\text { hecttplantation_tot }^{*} \\
\text { harvest_per_yr } \\
\text { life_cycle_yr/1000 }\end{array}$ & tonne & $\begin{array}{l}\text { Total seeds anticipated to be produced over } \\
\text { the life cycle of the plantation }\end{array}$ \\
\hline \multicolumn{4}{|l|}{ Avoided Products } \\
\hline $\begin{array}{l}\text { Indian Electricity } \\
\text { Generated }\end{array}$ & $\begin{array}{l}\text { bio_off_switch }{ }^{*} \text { life_biomass } \\
\text { _el }\end{array}$ & $\mathrm{kWh}$ & $\begin{array}{l}\text { Used to model the offset scenario where } \\
\text { Jatropha husks, leaves, and stems are } \\
\text { burned and converted to electricity to offset } \\
\text { Indian Electricity Generated }\end{array}$ \\
\hline $\begin{array}{l}\text { Heat, mixed chips from } \\
\text { forest, at furnace } \\
50 \mathrm{~kW} / \mathrm{CH} \mathrm{S}\end{array}$ & $\begin{array}{l}\text { (1- } \\
\text { bio_off_switch) }{ }^{*}(\text { life_biomas } \\
\text { s_en+ } \\
\text { life_husk_en)*furnace_eff }\end{array}$ & MJ & $\begin{array}{l}\text { Used to model the offset scenario where } \\
\text { Jatropha husks, leaves, and stems are } \\
\text { burned for heat used to offset generic heat } \\
\text { from a furnace run on mixed wood chips } \\
\text { from a forest. }\end{array}$ \\
\hline \multicolumn{4}{|r|}{ (1) } \\
\hline $\begin{array}{l}\text { Land: Transformation, } \\
\text { from traffic area, rail } \\
\text { network }\end{array}$ & plantation_tot & ha & $\begin{array}{l}\text { Transformation of land within Indian } \\
\text { Railways rail network }\end{array}$ \\
\hline $\begin{array}{l}\text { Land: Occupation, } \\
\text { permanent crop, fruit }\end{array}$ & plantation_tot*life_cycle_yr & ha a & $\begin{array}{l}\text { Amount of land occupied by the Jatropha } \\
\text { plantation times the number of years } \\
\text { occupied }\end{array}$ \\
\hline \multicolumn{4}{|l|}{ Materials/Fuels } \\
\hline $\begin{array}{l}\text { Fertilizing, by } \\
\text { broadcaster/CH S }\end{array}$ & $\begin{array}{l}\text { plantation_tot*fert_app_num } \\
{ }^{*} \text { life_cycle_yr }\end{array}$ & ha & $\begin{array}{l}\text { Energy required to distribute fertilizer to } \\
\text { entire plantation given number of times per } \\
\text { year for entire life cycle }\end{array}$ \\
\hline Irrigating $/ \mathrm{m} 3 / \mathrm{CH} S$ & $\begin{array}{l}\text { plantation_tot*irr_years* } \\
\text { req_irrigation }\end{array}$ & m3 & $\begin{array}{l}\text { Energy required to distribute irrigation water } \\
\text { to entire plantation given number of times } \\
\text { per year for entire life cycle }\end{array}$ \\
\hline $\begin{array}{l}\text { Jatropha Plantation, } \\
\text { Planted Ha, India }\end{array}$ & plantation_tot & ha & $\begin{array}{l}\text { Number of planted hectares required for the } \\
\text { plantation }\end{array}$ \\
\hline $\begin{array}{l}\text { Urea, as } \mathrm{N} \text {, at regional } \\
\text { storehouse/RER S }\end{array}$ & $\begin{array}{l}\text { fert_app_num/2*fert_switch* } \\
\text { (N_fert_req* } \\
\text { plantation_tot*life_cycle_yr*t } \\
\text { ree_density/reinhardt_dens) }\end{array}$ & $\mathrm{kg}$ & $\begin{array}{l}\text { Reinhardt fertilization and plantation } \\
\text { operation values }\end{array}$ \\
\hline $\begin{array}{l}\text { Potassium chloride, as } \\
\mathrm{K}_{2} \mathrm{O} \text {, at regional } \\
\text { storehouse/RER S }\end{array}$ & $\begin{array}{l}\text { fert_app_num/2*fert_switch* } \\
\text { (K2O_fert_req* } \\
\text { plantation_tot*life_cycle_yr*t } \\
\text { ree_density/reinhardt_dens) }\end{array}$ & $\mathrm{kg}$ & $\begin{array}{l}\text { Reinhardt fertilization and plantation } \\
\text { operation values }\end{array}$ \\
\hline $\begin{array}{l}\text { Single } \\
\text { superphosphate, as } \\
\mathrm{P}_{2} \mathrm{O}_{5} \text {, at regional } \\
\text { storehouse/RER S }\end{array}$ & $\begin{array}{l}\text { fert_app_num/2*fert_switch* } \\
\text { (P2O5_fert_req* } \\
\text { plantation_tot*life_cycle_yr*t } \\
\text { ree_density/reinhardt_dens) }\end{array}$ & $\mathrm{kg}$ & $\begin{array}{l}\text { Reinhardt fertilization and plantation } \\
\text { operation values }\end{array}$ \\
\hline $\begin{array}{l}\text { Diesel, at regional } \\
\text { storage/RER S }\end{array}$ & $\begin{array}{l}\text { diesel_fuel_cul*tree_density } \\
\text { /reinhardt_dens* } \\
\text { plantation_tot*life_cycle_yr* } \\
\text { spec_grav_dies }\end{array}$ & $\mathrm{kg}$ & $\begin{array}{l}\text { Reinhardt fertilization and plantation } \\
\text { operation values }\end{array}$ \\
\hline $\begin{array}{l}\text { Indian Electricity } \\
\text { Delivered }\end{array}$ & $\begin{array}{l}\text { plantation_elec*life_cycle_yr } \\
{ }^{*} \text { plantation_tot } 10000\end{array}$ & kWh & \\
\hline Electricity/heat & & & \\
\hline
\end{tabular}




\begin{tabular}{lll}
\hline Module Flows* & $\begin{array}{l}\text { Input Value } \\
\text { or Variable }\end{array}$ & Units Comments \\
\cline { 2 - 3 } Emissions to air & N2O_volatized & $\mathrm{kg}$ \\
Dinitrogen monoxide & Emissions to water & \\
Emissions to soil & & \\
\hline * Drawn from ecoinvent 2.0 or other custom modules &
\end{tabular}

* Drawn from ecoinvent 2.0 or other custom modules 
Table A-8. Jatropha Oil, at Extraction Facility, India Custom Module

\begin{tabular}{|c|c|c|c|}
\hline Module Flows* & Input Value or Variable & Units & Comments \\
\hline \multicolumn{4}{|l|}{ Products } \\
\hline Jatropha Oil & oil_recov_eff & tonne & \\
\hline \multicolumn{4}{|l|}{ Avoided Products } \\
\hline $\begin{array}{l}\text { Urea, as } \mathrm{N} \text {, at regional } \\
\text { storehouse/RER S }\end{array}$ & $\begin{array}{l}\text { (1-oil_recov_eff)* } \\
\text { seed_cake_rep*seed_cake_N }\end{array}$ & tonne & $\begin{array}{l}\text { Avoided urea fertilizer production that is } \\
\text { due to the generation and use of } \\
\text { Jatropha seed cake }\end{array}$ \\
\hline $\begin{array}{l}\text { Single } \\
\text { superphosphate, as } \\
\mathrm{P}_{2} \mathrm{O}_{5} \text {, at regional } \\
\text { storehouse/RER S }\end{array}$ & $\begin{array}{l}\text { (1-oil_recov_eff)* } \\
\text { seed_cake_rep*seed_cake_P }\end{array}$ & tonne & $\begin{array}{l}\text { Avoided single super phosphate } \\
\text { production that is due to the generation } \\
\text { and use of Jatropha seed cake }\end{array}$ \\
\hline $\begin{array}{l}\text { Potassium nitrate, as } \\
\mathrm{K}_{2} \mathrm{O} \text {, at regional } \\
\text { storehouse/RER S }\end{array}$ & $\begin{array}{l}\text { (1-oil_recov_eff)* } \\
\text { seed_cake_rep*seed_cake_K }\end{array}$ & tonne & $\begin{array}{l}\text { Avoided potassium nitrate production that } \\
\text { is due to the generation and use of } \\
\text { Jatropha seed cake }\end{array}$ \\
\hline \multicolumn{4}{|l|}{ Resources } \\
\hline \multicolumn{4}{|l|}{ Materials/Fuels } \\
\hline $\begin{array}{l}\text { Jatropha Seeds } \\
\text { Harvested from } \\
\text { Plantation }\end{array}$ & 1 & tonne & \\
\hline $\begin{array}{l}\text { Hexane, at plant/RER } \\
\text { S }\end{array}$ & solvent_hexane & $\mathrm{kg}$ & Assumes that $99 \%$ of hexane is recycled \\
\hline Oil mill/CH/l S & jatoil_plnt_pce*oil_recov_eff & $\mathrm{p}$ & $\begin{array}{l}\text { Fraction of oil extraction plant } \\
\text { infrastructure allocated to Jatropha oil } \\
\text { produced in this module }\end{array}$ \\
\hline $\begin{array}{l}\text { Tap water, at user/RER } \\
\text { S }\end{array}$ & solvent_water & tonne & $\begin{array}{l}\text { Water quality requirements not specified, } \\
\text { assumes that tap water is adequate for } \\
\text { this process }\end{array}$ \\
\hline $\begin{array}{l}\text { Operation, lorry 3.5- } \\
16 t \text {, fleet average/RER } \\
\text { S }\end{array}$ & seed_tran_dist/16 & $\mathrm{km}$ & $\begin{array}{l}\text { Base case assumes that the Jatropha oil } \\
\text { extraction facility is located within } 50 \mathrm{~km} \\
\text { of the plantation }\end{array}$ \\
\hline \multicolumn{4}{|l|}{ Electricity/heat } \\
\hline $\begin{array}{l}\text { Steam, for chemical } \\
\text { processes, at } \\
\text { plant/RER S }\end{array}$ & solvent_steam & $\mathrm{kg}$ & \\
\hline $\begin{array}{l}\text { Indian Electricity } \\
\text { Delivered }\end{array}$ & solvent_elec & kWh & \\
\hline \multicolumn{4}{|l|}{ Emissions to air } \\
\hline \multicolumn{4}{|l|}{ Emissions to water } \\
\hline Emissions to soil & & & \\
\hline
\end{tabular}

* Drawn from ecoinvent 2.0 or other custom modules 
Table A-9. Biodiesel Production, Base-catalyzed Transesterification, India, at Plant Custom Module

\begin{tabular}{|c|c|c|c|}
\hline Module Flows* & $\begin{array}{l}\text { Input Values } \\
\text { or Variable }\end{array}$ & Units & Comments \\
\hline \multicolumn{4}{|l|}{ Products } \\
\hline Biodiesel & 1 & tonne & Biodiesel output \\
\hline \multicolumn{4}{|l|}{ Avoided Products } \\
\hline $\begin{array}{l}\text { Glycerine, from } \\
\text { epichlorohydrin, at } \\
\text { plant/RER S }\end{array}$ & $\begin{array}{l}\text { glyc_yield*jat } \\
\text { oil_required*0 } \\
.97\end{array}$ & tonne & $\begin{array}{l}\text { Glycerine produced during process, assumed to offset traditional } \\
\text { glycerine production using Western European technology; } 0.97 \\
\text { represents the assumed glycerol to glycerine conversion } \\
\text { efficiency. }\end{array}$ \\
\hline \multicolumn{4}{|r|}{ 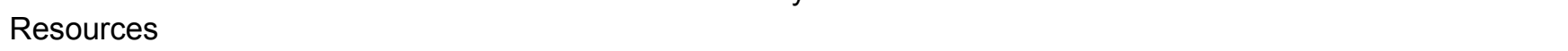 } \\
\hline \multicolumn{4}{|l|}{ Materials/Fuels } \\
\hline $\begin{array}{l}\text { Methanol, at plant/GLO } \\
\text { S }\end{array}$ & $\begin{array}{l}\text { transest_meth } \\
{ }^{*}(1- \\
\text { meth_switch }) \\
+ \\
\text { transest_meth } \\
{ }^{*} \\
(1- \\
\text { meth_recycle) } \\
{ }^{*} \text { meth_switch }\end{array}$ & $\mathrm{kg}$ & $\begin{array}{l}\text { Methanol module does not include transport distance. While the } \\
\text { Planning Commission of India (Planning Commission 2003), } \\
\text { does not explicitly state if methanol recovery is used in their } \\
\text { sample facility in Annexure X, the text throughout the document } \\
\text { suggests that methanol recovery is a mandatory part of the } \\
\text { process because methanol is used in excess during biodiesel } \\
\text { transesterification and biodiesel with excessive methanol cannot } \\
\text { meet ASTM standards for methanol content, flash point, or both. } \\
\text { Annexure X also lists methanol "consumed" for an economic } \\
\text { analysis as opposed to methanol "supplied." The use of } \\
\text { "consumed" and the discussion in the text lead the authors to } \\
\text { assume that methanol recovery is included in the analysis of the } \\
\text { sample plant in Annexure X. SRS Engineering (2009) and } \\
\text { Wintek Corporation (2009) also suggest that methanol recovery } \\
\text { is critical to the economics of a biodiesel production facility. }\end{array}$ \\
\hline $\begin{array}{l}\text { Sulphuric acid, liquid, at } \\
\text { plant/RER S }\end{array}$ & $\begin{array}{l}\text { transest_mina } \\
\text { cd }\end{array}$ & $\mathrm{kg}$ & $\begin{array}{l}\text { Transportation distance for sulfuric acid is unknown. } \\
\text { Composition of mineral acid required is unknown. Sulfuric acid is } \\
\text { currently assumed in this analysis based on feedback from } \\
\text { Indian Oil Corporation }\end{array}$ \\
\hline $\begin{array}{l}\text { Potassium hydroxide, at } \\
\text { regional storage/RER S }\end{array}$ & transest_KOH & $\mathrm{kg}$ & Potassium hydroxide module includes transport distance \\
\hline Jatropha Oil & jatoil_required & tonne & $\begin{array}{l}\text { Conversion efficiency of Jatropha oil to biodiesel is } \\
\text { approximately } 95 \% \text {. }\end{array}$ \\
\hline $\begin{array}{l}\text { Vegetable oil } \\
\text { esterification plant/CH/l } \\
\text { S }\end{array}$ & $\begin{array}{l}\text { bio_plant_pie } \\
\text { ce }\end{array}$ & $\mathrm{p}$ & $\begin{array}{l}\text { Fraction of biodiesel transesterification plant infrastructure } \\
\text { impacts attributed to each tonne produced }\end{array}$ \\
\hline \multicolumn{4}{|l|}{ Electricity/heat } \\
\hline $\begin{array}{l}\text { Indian Electricity } \\
\text { Delivered }\end{array}$ & transest_elect & kWh & $\begin{array}{l}\text { Energy data are per tonne of biodiesel generated at a 100,000 } \\
\text { MT/year biodiesel facility. }\end{array}$ \\
\hline $\begin{array}{l}\text { Steam, for chemical } \\
\text { processes, at plant/RER } \\
\text { S }\end{array}$ & $\begin{array}{l}\text { transest_stea } \\
\mathrm{m}\end{array}$ & $\mathrm{kg}$ & $\begin{array}{l}\text { In absence of specific Indian steam data, generic steam } \\
\text { production for use in chemical processes in Europe is used. } \\
\text { Amount of steam is specific to the Indian transesterification } \\
\text { plant. }\end{array}$ \\
\hline $\begin{array}{l}\text { Operation, lorry } 3.5-16 t \\
\text { fleet average/RER S }\end{array}$ & $\begin{array}{l}\text { solvent_trans* } \\
\text { jatoil_required } \\
\text { /16 }\end{array}$ & $\mathrm{km}$ & $\begin{array}{l}\text { Transport parameter allows testing the impact of oil extraction } \\
\text { and biodiesel transesterification facilities being in separate } \\
\text { locations }\end{array}$ \\
\hline $\begin{array}{l}\text { Emissions to air } \\
\text { Emissions to water } \\
\text { Emissions to soil }\end{array}$ & & & \\
\hline
\end{tabular}

* Drawn from ecoinvent 2.0 or other custom modules 
Table A-10. Biodiesel Blending, India, at Processing Custom Module

\begin{tabular}{|c|c|c|c|}
\hline Module Flows* & $\begin{array}{l}\text { Input Values } \\
\text { or Variable }\end{array}$ & Units & Comments \\
\hline \multicolumn{4}{|l|}{ Products } \\
\hline Blended Fuel & 1 & tonne & \\
\hline \multicolumn{4}{|l|}{ Avoided Products } \\
\hline \multicolumn{4}{|l|}{ Resources } \\
\hline \multicolumn{4}{|l|}{ Materials/Fuels } \\
\hline Biodiesel & biodiesel_blend & tonne & $\begin{array}{l}\text { Biodiesel blend is a user-chosen } \\
\text { parameter to test the impacts of } \\
\text { different biodiesel blending scenarios. } \\
\text { India has experimented with multiple } \\
\text { field trials of B5, B10, and B20. }\end{array}$ \\
\hline $\begin{array}{l}\text { Diesel, at regional } \\
\text { storage/RER U --> } \\
\text { India }\end{array}$ & 1-biodiesel_blend & tonne & $\begin{array}{l}\text { The remainder of the fuel not } \\
\text { comprised of biodiesel is conventional } \\
\text { fossil diesel produced in the Indian } \\
\text { context. }\end{array}$ \\
\hline $\begin{array}{l}\text { Operation, freight } \\
\text { train/RER U }\end{array}$ & $\begin{array}{l}\text { biodiesel_distbiodiesel_ble } \\
\text { nd }\end{array}$ & tkm & $\begin{array}{l}\text { Rail transport is assumed for } \\
\text { biodiesel from biodiesel } \\
\text { transesterification plant to blending } \\
\text { facility. }\end{array}$ \\
\hline $\begin{array}{l}\text { Chemicals organic, } \\
\text { at plant/GLO U }\end{array}$ & biodiesel_blend*biostabilizer & tonne & $\begin{array}{l}\text { Represents stabilizer added to } \\
\text { biodiesel }\end{array}$ \\
\hline $\begin{array}{l}\text { Chemicals inorganic, } \\
\text { at plant/GLO U }\end{array}$ & $\begin{array}{l}\text { (1-biodiesel_blend)* } \\
\text { cetane_enhancer }\end{array}$ & tonne & $\begin{array}{l}\text { Represents cetane enhancer added } \\
\text { to diesel fuel }\end{array}$ \\
\hline \multicolumn{4}{|c|}{ Electricity/heat } \\
\hline $\begin{array}{l}\text { Indian Electricity } \\
\text { Delivered }\end{array}$ & $\begin{array}{l}\text { ceil(biodiesel_blend)* } \\
\text { bio_blend_elec*1000 }\end{array}$ & kWh & $\begin{array}{l}\text { Electricity required to blend diesel } \\
\text { with biodiesel }\end{array}$ \\
\hline \multicolumn{4}{|l|}{ Emissions to air } \\
\hline \multicolumn{4}{|l|}{ Emissions to water } \\
\hline Emissions to soil & & & \\
\hline
\end{tabular}

* Drawn from ecoinvent 2.0 or other custom modules 
Table A-11. Crude Oil at Indian Mix Custom Module

\begin{tabular}{|c|c|c|c|}
\hline Module Flows* & Input Values or Variable & Units & Comments \\
\hline \multicolumn{4}{|l|}{ Products } \\
\hline Crude Oil, Indian Mix & 1 & tonne & \\
\hline \multicolumn{4}{|l|}{ Avoided Products } \\
\hline \multicolumn{4}{|l|}{ Resources } \\
\hline \multicolumn{4}{|l|}{ Materials/Fuels } \\
\hline $\begin{array}{l}\text { Crude oil, at } \\
\text { production/NG S }\end{array}$ & crude_Nigeria & tonne & $\begin{array}{l}\text { Represents foreign oil extraction from } \\
\text { the Niger delta of Nigeria; India's } \\
\text { foreign oil primarily comes from the } \\
\text { Middle East and Nigeria. }\end{array}$ \\
\hline $\begin{array}{l}\text { Crude oil, at production } \\
\text { onshore/RME S }\end{array}$ & crude_mid_east & tonne & $\begin{array}{l}\text { Represents foreign crude oil extraction } \\
\text { from the Middle East; the largest } \\
\text { percentage of India's foreign crude oil } \\
\text { comes from Saudi Arabia. }\end{array}$ \\
\hline $\begin{array}{l}\text { Crude oil, at production } \\
\text { offshore/GB S }\end{array}$ & crude_bombay & tonne & $\begin{array}{l}\text { Domestic oil production is assumed to } \\
\text { occur in India's largest oil field, } \\
\text { Bombay High, and to be transported to } \\
\text { VIZAG refinery terminal to be } \\
\text { combined with the foreign crude via oil } \\
\text { tanker }\end{array}$ \\
\hline \multicolumn{4}{|l|}{ Electricity/heat } \\
\hline \multicolumn{4}{|l|}{ Emissions to air } \\
\hline \multicolumn{4}{|l|}{ Emissions to water } \\
\hline Emissions to soil & & & \\
\hline
\end{tabular}

* Drawn from ecoinvent 2.0 or other custom modules

Table A-12. Crude Oil Delivered to Refinery via Ocean Tanker, India Custom Module

\begin{tabular}{|c|c|c|c|}
\hline Module Flows* & Input Values or Variable & Units & Comments \\
\hline \multicolumn{4}{|l|}{ Products } \\
\hline $\begin{array}{l}\text { Crude Oil at Indian } \\
\text { Refinery }\end{array}$ & 1 & tonne & \\
\hline \multicolumn{4}{|l|}{ Avoided Products } \\
\hline \multicolumn{4}{|l|}{ Resources } \\
\hline \multicolumn{4}{|l|}{ Materials/Fuels } \\
\hline Crude Oil, Indian Mix & 1 & tonne & \\
\hline $\begin{array}{l}\text { Operation, } \\
\text { transoceanic } \\
\text { tanker/OCE S }\end{array}$ & crude_ocean_trn & $\mathrm{tkm}$ & $\begin{array}{l}\text { Represents the weighted distance of } \\
\text { transporting crude oil from Bombay } \\
\text { and Saudi Arabia to the refinery at } \\
\text { VIZAG via a transoceanic tanker. }\end{array}$ \\
\hline \multicolumn{4}{|l|}{ Electricity/heat } \\
\hline \multicolumn{4}{|l|}{ Emissions to air } \\
\hline \multicolumn{4}{|l|}{ Emissions to water } \\
\hline Emissions to soil & & & \\
\hline
\end{tabular}

* Drawn from ecoinvent 2.0 or other custom modules 
Table A-13. Indian Rail Transport Custom Module

\begin{tabular}{llll}
\hline $\begin{array}{l}\text { Module Flows* } \\
\text { Products }\end{array}$ & Input Values or Variable & Units Comments \\
\cline { 2 - 3 } $\begin{array}{l}\text { Indian Rail Transport } \\
\text { Avoided Products }\end{array}$ & 1000 & $\mathrm{tkm}$ & \\
$\begin{array}{l}\text { Resources } \\
\text { Materials/Fuels }\end{array}$ & & \\
$\begin{array}{l}\text { Blended Fuel } \\
\text { Electricity/heat }\end{array}$ & loco_bio_fuel & $\mathrm{kg}$ & \\
$\begin{array}{l}\text { Emissions to air } \\
\text { Carbon dioxide }\end{array}$ & $\begin{array}{l}\text { locomotive_CO2* } \\
\text { loco_bio_fuel }\end{array}$ & $\mathrm{kg}$ & $\begin{array}{l}\mathrm{CO}_{2} \text { emissions from just the diesel } \\
\text { portion of the blend }\end{array}$ \\
Emissions to water & & & \\
Emissions to soil & & & \\
\hline
\end{tabular}

* Drawn from ecoinvent 2.0 or other custom modules

Table A-14. India Road Transport Custom Module

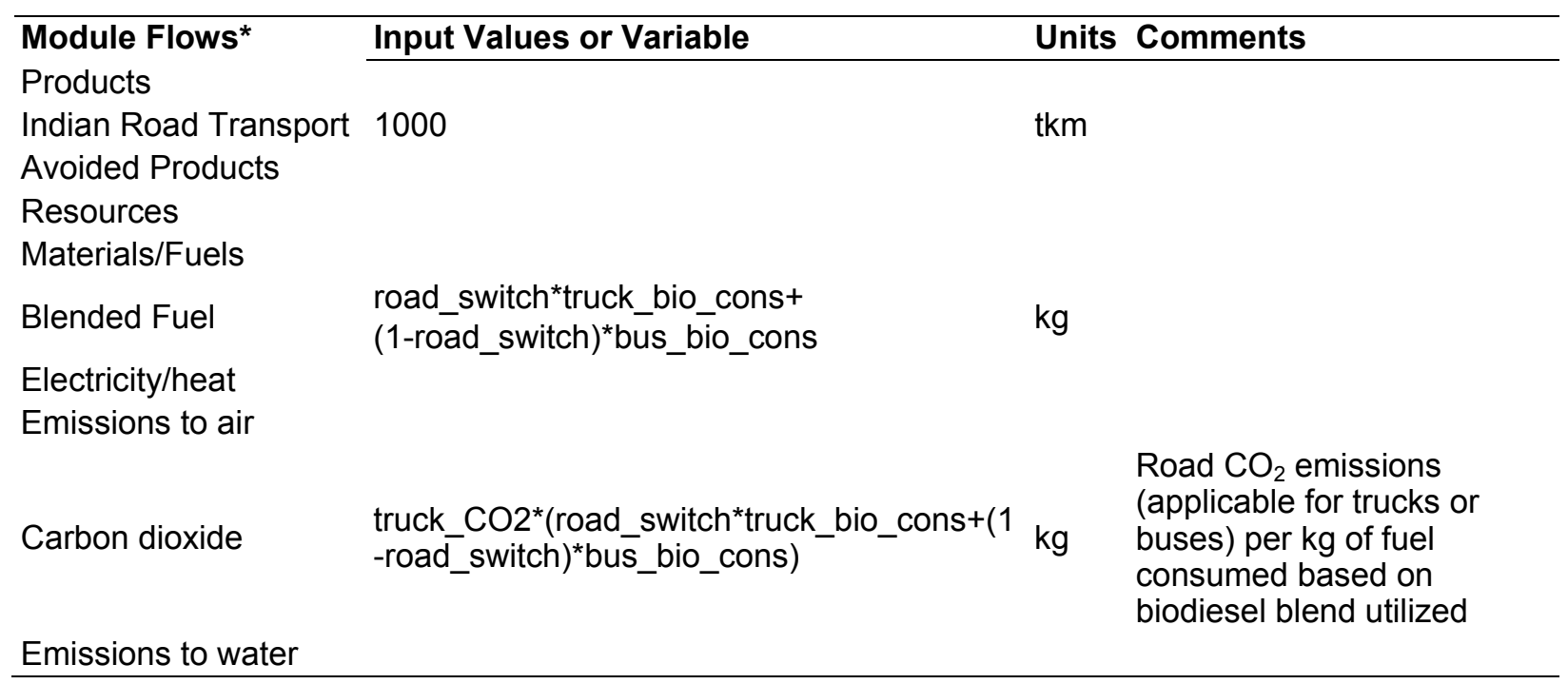

* Drawn from ecoinvent 2.0 or other custom modules 


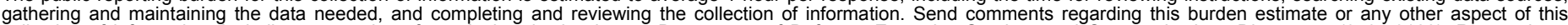

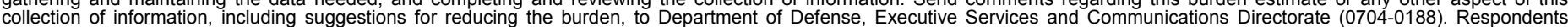

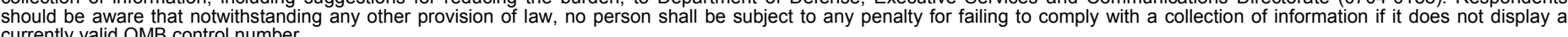

PLEASE DO NOT RETURN YOUR FORM TO THE ABOVE ORGANIZATION.

\section{REPORT DATE (DD-MM-YYYY) May 2010}

\section{TITLE AND SUBTITLE}

Life Cycle Assessment Comparing the Use of Jatropha Biodiesel in the Indian Road and Rail Sectors

\section{DATES COVERED (From - To)}

5a. CONTRACT NUMBER

DE-AC36-08-GO28308

5b. GRANT NUMBER

5c. PROGRAM ELEMENT NUMBER

5d. PROJECT NUMBER

NREL/TP-6A2-47462

5e. TASK NUMBER

BB07.9610

5f. WORK UNIT NUMBER
7. PERFORMING ORGANIZATION NAME(S) AND ADDRESS(ES)

National Renewable Energy Laboratory

1617 Cole Blvd.

Golden, CO 80401-3393

9. SPONSORING/MONITORING AGENCY NAME(S) AND ADDRESS(ES)
8. PERFORMING ORGANIZATION REPORT NUMBER

NREL/TP-6A2-47462

10. SPONSOR/MONITOR'S ACRONYM(S) NREL

11. SPONSORING/MONITORING AGENCY REPORT NUMBER

\section{DISTRIBUTION AVAILABILITY STATEMENT}

National Technical Information Service

U.S. Department of Commerce

5285 Port Royal Road

Springfield, VA 22161

\section{SUPPLEMENTARY NOTES}

\section{ABSTRACT (Maximum 200 Words)}

This life cycle assessment of Jatropha biodiesel production and use evaluates the net greenhouse gas (GHG) emission (not considering land-use change), net energy value (NEV), and net petroleum consumption impacts of substituting Jatropha biodiesel for conventional petroleum diesel in India. Several blends of biodiesel with petroleum diesel are evaluated for the rail freight, rail passenger, road freight, and road-passenger transport sectors that currently rely heavily on petroleum diesel. For the base case, Jatropha cultivation, processing, and use conditions that were analyzed, the use of B20 results in a net reduction in GHG emissions and petroleum consumption of $14 \%$ and $17 \%$, respectively, and a NEV increase of $58 \%$ compared with the use of $100 \%$ petroleum diesel. While the road-passenger transport sector provides the greatest sustainability benefits per 1000 gross tonne kilometers, the road freight sector eventually provides the greatest absolute benefits owing to substantially higher projected utilization by year 2020. Nevertheless, introduction of biodiesel to the rail sector might present the fewest logistic and capital expenditure challenges in the near term. Sensitivity analyses confirmed that the sustainability benefits are maintained under multiple plausible cultivation, processing, and distribution scenarios. However, the sustainability of any individual Jatropha plantation will depend on site-specific conditions.

\section{SUBJECT TERMS}

life cycle assessment; LCA; sensitivity analyses; sensitivity analysis; Jatropha; biodiesel; Jatropha biodiesel; petroleum diesel; Jatropha production; Jatropha cultivation; India; transportation; transport sectors; net greenhouse gas emissions; net energy value (NEV); net petroleum consumption

\begin{tabular}{|c|c|c|c|c|}
\hline \multicolumn{3}{|c|}{ 16. SECURITY CLASSIFICATION OF: } & \multirow{2}{*}{$\begin{array}{l}\text { 17. LIMITATION } \\
\text { OF ABSTRACT } \\
\text { UL }\end{array}$} & \multirow{2}{*}{$\begin{array}{ll}\text { 18. } & \text { NUMBER } \\
\text { OF PAGES }\end{array}$} \\
\hline $\begin{array}{l}\text { a. REPORT } \\
\text { Unclassified }\end{array}$ & $\begin{array}{l}\text { b. ABSTRACT } \\
\text { Unclassified }\end{array}$ & $\begin{array}{l}\text { c. THIS PAGE } \\
\text { Unclassified }\end{array}$ & & \\
\hline
\end{tabular}

19a. NAME OF RESPONSIBLE PERSON
19b. TELEPHONE NUMBER (Include area code)

